\title{
180
}

| $\mathbf{3} \mathbf{1} \mathbf{\$}$ tUIES RELATED TO WILDERNESS PRIMITIVE AREAS 39092042132177

(ii.

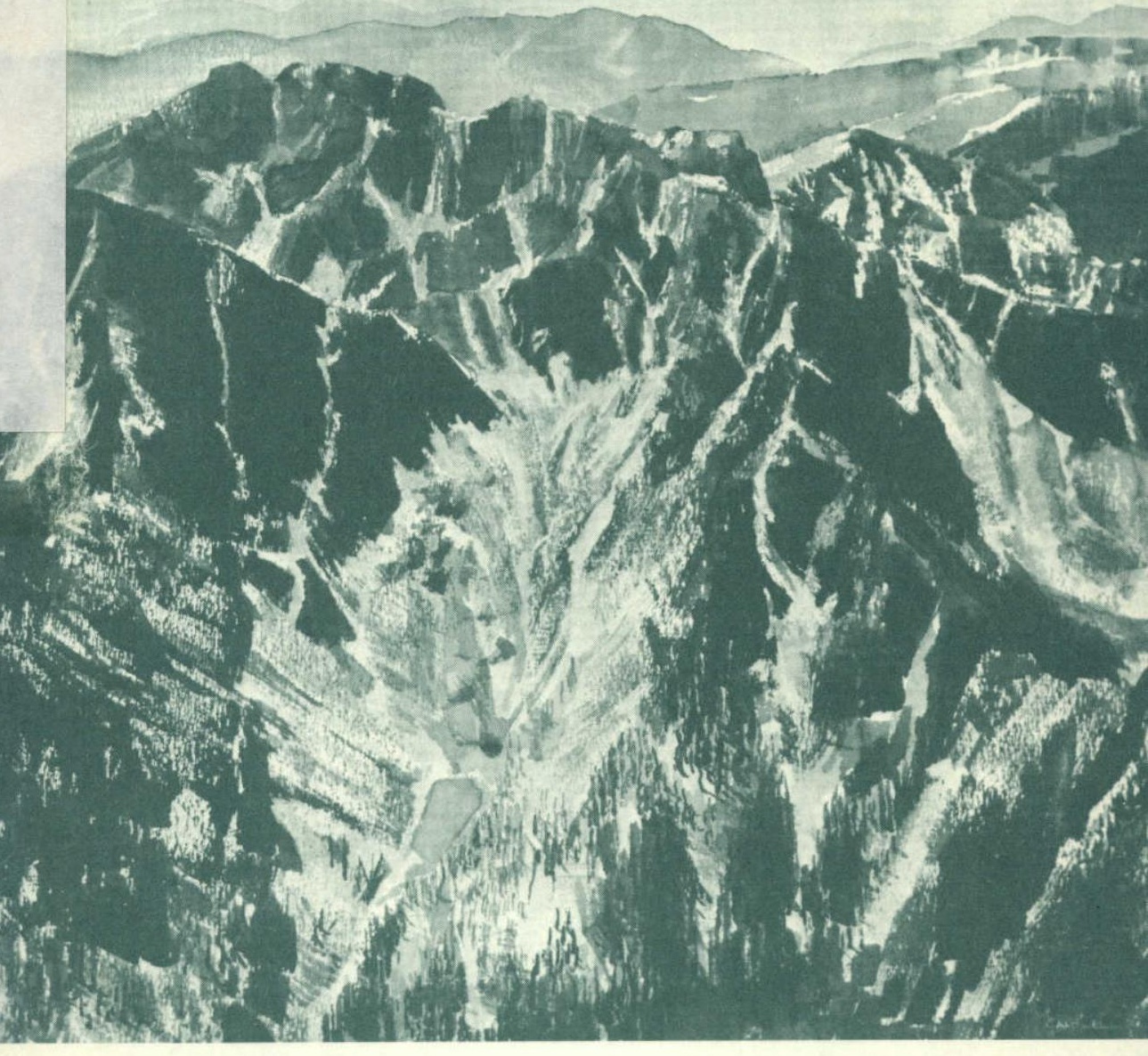

GLACIER,
WYOMING

metadc958039

GEOLOGICAL SURVEY BULLETIN 1319-F

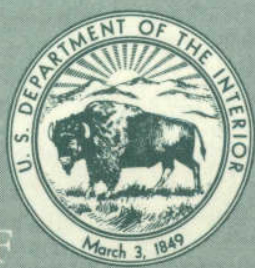





\section{Mineral Resources of the Glacier Primitive Area, Wyoming}

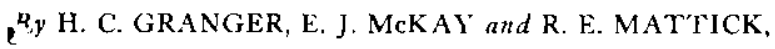

U.S. Geologicai, Survey,

and by LOWELL L. PATTEN and PAUL. McILROY,

U.S. Bureau of Mines

STUDIES RELATED TO WILDERNESS-PRIMITIVE AREAS

GEOLOGICAL SURVEY BULLE'TIN 1319-F

An evaluation of the mineral potential of the area

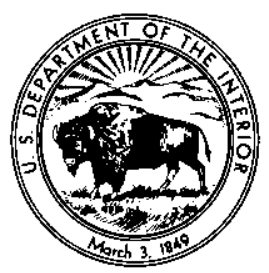




\section{UNITED STATES DEPARTMENT OF THE INTERIOR}

\section{GEOLOGICAL SURVEY}

William T. Pecora, Director

L,ibrary of Congress catalog-card No, 73-609781

For sale by the Superintendent of Documents, U.S. Government Printing Office Washington, D.C. 20402 


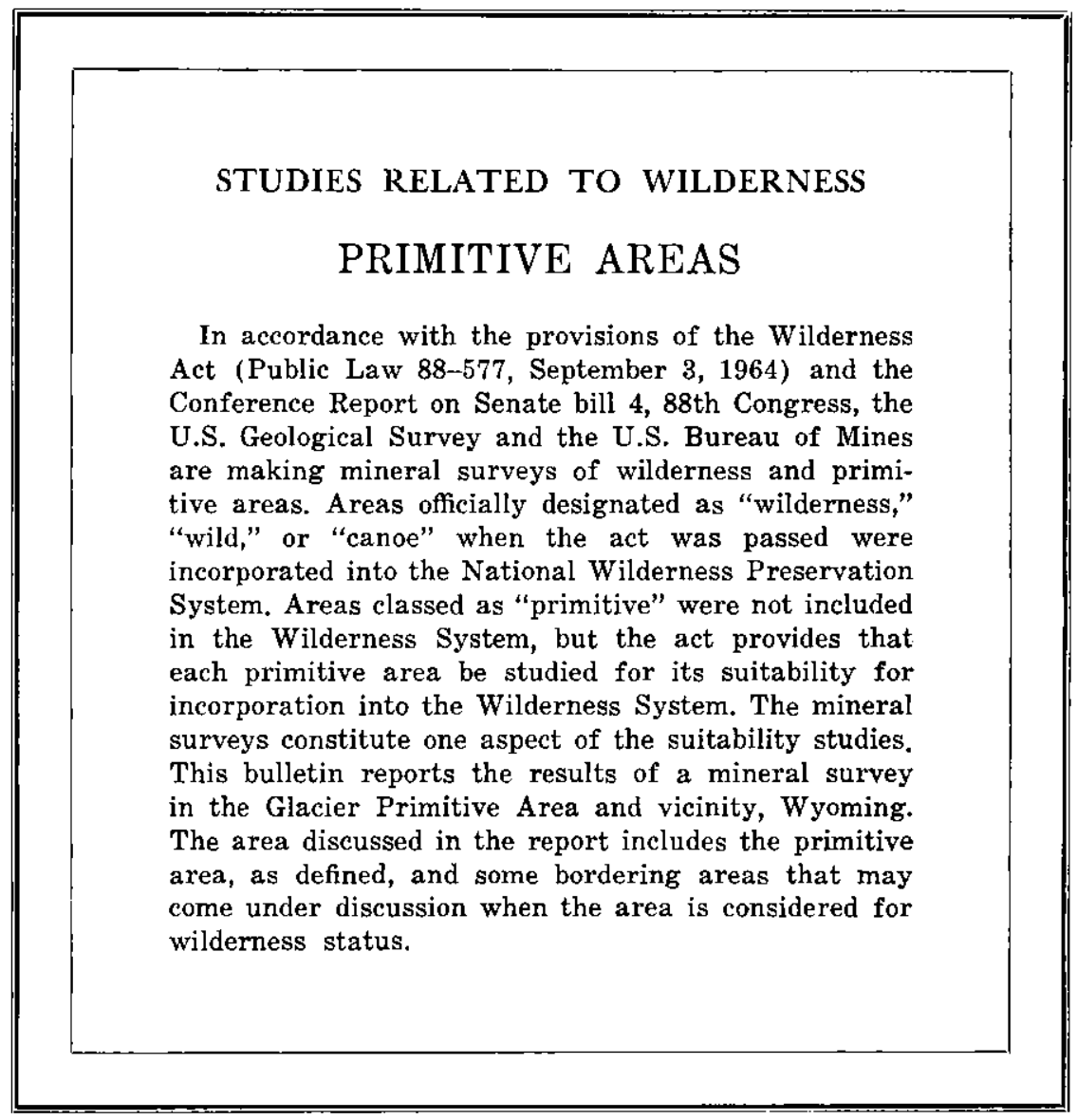





\section{CONTENTS}

\begin{tabular}{|c|c|}
\hline & Page \\
\hline Immary & F1 \\
\hline troduction & \\
\hline Previous work & \\
\hline Acknowledgments & \\
\hline $\log y$ - & \\
\hline Geologic setting and history & $\mathbf{9}$ \\
\hline Precambrian rocks & 10 \\
\hline Gneissic rocks & 11 \\
\hline Ultramafic rocks & 14 \\
\hline Migmatite & 15 \\
\hline Mount Helen structural belt & 20 \\
\hline Middle Mountain & 21 \\
\hline c granite & 22 \\
\hline c bodies & 23 \\
\hline bodies & 24 \\
\hline - & 24 \\
\hline Paleozoic rocks & 27 \\
\hline Tertia & 30 \\
\hline Quater & 31 \\
\hline deposits & 31 \\
\hline - & 32 \\
\hline bris & 32 \\
\hline - & 32 \\
\hline $\begin{array}{c}-1 \\
-1\end{array}$ & 33 \\
\hline Alteration related to faults & 38 \\
\hline 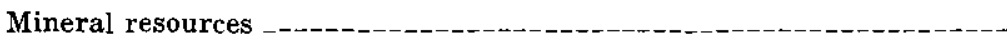 & 39 \\
\hline ction & 39 \\
\hline ng and analytical techniques & 40 \\
\hline ipling stream sediments for base metals & 41 \\
\hline (1) & 44 \\
\hline occurrences - & 45 \\
\hline rite-bearing veins _-_----_--_-_ & 45 \\
\hline alfide-mineral occurrences & 47 \\
\hline veins & 47 \\
\hline Kel & 48 \\
\hline terals & 49 \\
\hline 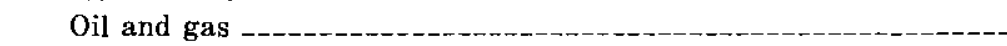 & 50 \\
\hline Mines & 50 \\
\hline 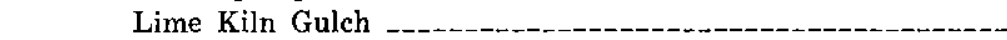 & 52 \\
\hline ain & 58 \\
\hline mring Croek & \\
\hline
\end{tabular}


Mineral Resources-Continued

Mines and Prospects-Continued

Red Creek

Moon Lake

Dinwoody Creek _.-_- 56

Union Pass ..-_-_-_- 56

Decorative stone _._- 57

Union Pass uranium claims _-_-_-_-_-_-_-_-_-_-_-_-_- 57

Other prospects

Interpretation of aeromagnetic data _._- 57

Conclusions _........- 60

References cited --_-_-_-_-_- 60

Index _... 111

\section{ILLUSTRATIONS}

[Plates are in pocket]

Plate 1. Geologic map of the Glacier Primitive Area, Wyoming.

2. Map of the Glacier Primitive Area, Wyoming, showing geochemical sample localities.

FIGURE 1. Index map of Wyoming showing area studied

2-16. Photographs:

2. Gannett Peak flanked by Mount Warren and Koven Peak as seen from the southern end of Downs Glacier

3. Two prominent physiographic features: The Fortress and the Brown Cliffs

5. Broad glaciated and alluviated part of the valley of Dinwoody Creek

6. Part of a brecciated amphibolite block included in migmatite, showing the intricate pattern of cementation by pegmatite

7. Chimney Rock, a landmark along the south edge of upper Horse Ridge

8. Closeup of Chimney Rock from Horse Ridge

9. Migmatite showing disoriented blocks of biotite-

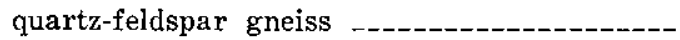

10. Migmatite showing the speckled hornblende phase of the porphyritic granite injected into biotite-quartz-feldspar gneiss

11. Diabase dike

12. The Paleozoic sedimentary sequence

13. Uplifted segment of peneplain and terminal moraine

14. Surfaces covered by felsenmeer

15. The beveling effect of peneplanation on Horse 
Page

Figures 2-16. Photographs-Continued

16. Topographic lineament formed along the Alpine

Lakes shear zone

17. Map showing claims and leases in and near the Glacier Primitive Area

TABLES

TABLE 1. Measured thicknesses of Paleozoic sedimentary rocks in and near the Glacier Primitive Area

F28

2. Some compositional differences in sediment-sample pairs collected from the same sample sites at different times --

3. Some stream-sediment samples that contain anomalous lead or copper according to semiquantitative spectrographic analyses but show normal $\mathrm{CxHM}$ analyses ----

4. Crustal abundance of some metallic elements compared with their abundance in rocks of the Glacier Primitive Area

5-11. Analyses of samples from the Glacier Primitive Area:

5. Sedimentary rock samples

6. Felsic rock samples 66

7. Mafic and ultramafic rock samples 76

8. Miscellaneous rock samples 80

9. Breccia and vein samples 82

10. Stream-sediment and soil samples - 86

11. Pan-concentrated stream-sediment samples 104 



\title{
STUDIES RELATED TO WILDERNESS-PRIMITIVE AREAS
}

\section{MINERAL RESOURCES OF THE GLACIER PRIMITIVE AREA, WYOMING}

\author{
By H. C. Granger, E. J. McKay, and R. E. MatTick, \\ U.S. GEOLOGICAL SURVEY, \\ and by Lowell L. Patten and Paul Mcllroy, \\ U.S. BUREAU of MINES
}

\section{SUMMARY}

A mineral survey of the Glacier Primitive Area and an adjoining area to the northwest was made in 1968 and 1969 by the U.S. Geological Survey and the U.S. Bureau of Mines. The study area was mapped geologically, an aeromagnetic survey was made, a total of 1,076 samples (593 stream-sediment and panned-concentrate samples and 483 rock samples) was collected and analyzed, and known mineral deposits and claims were appraised from both geological and mineral-potential viewpoints.

The area studied is along the northeast flank of the Wind River Range in western Wyoming and includes the Glacier Primitive Area, enclosing about 277 square miles, and an adjacent area of about 65 square miles. It contains some of the most spectacular alpine scenery in the Western United States. From the high, craggy, glacier-dominated spine of the Continental Divide, the terrain drops toward the east and north onto an intricately incised series of peneplained uplands and rounded hills. Much of the area is dotted with glacially carved lakes connected and drained by cascading mountain streams. Elevations range from 13,785 feet at the crest of Gannett Peak, the highest in Wyoming, to about 6,790 feet in the valley of Dinwoody Creek, whose source is partly in glaciers on the flanks of Gannett Peak. A large part of the area is above the tree line, but the lower elevations are partly covered with spruce, pine, grasses, and low-growing flowering plants.

The study area is largely underlain by Precambrian crystalline rocks but is flanked along the northeast edge by a sequence of Paleozoic marine sedimentary rocks which once also mantled the crystalline core of the Wind River Range. The north-central part of the study area is occupied by a north-trending granitic mass named the Middle Mountain batholith, which is about 5 miles wide and 25 miles long. This body grades outward into migmatite and agmatite which, in turn, grade outward into paragneisses that form the framework of the core of the range. These rocks terminate rather abruptly on the south at a northwest-trending zone that probably represents a very old metamorphosed fault zone. South of this zone a different migmatite unit appears to border another granitic batholith whose northern parts are represented by lobes of porphyritic granite which project only short distances into the primitive area. 
The study disclosed no mineral deposits that can be mined economically, and none of the several mineralized localities appears to have possibilities for future development. A small hematitic breccia zone in Precambrian gneiss a few miles north of the primitive area reportedly yielded a few tons of uranium ore, but this zone was apparently mined out. Another small uranium prospect in the lower part of the Paleozoic sequence is of subeconomic grade. Locally, a red-shale unit in the Amsden Formation of Mississippian and Pennsylvanian age contains lenses of oolitic iron ore, but these are too small and sparse to warrant further exploration.

A few short, narrow veins in the Precambrian rocks contain sulfide minerals. These are typically oxidized at the surface, but samples of the gossan and of the sulfides show that they contain only negligible amounts of base and precious metals. A few stream-sediment samples were anomalous in metal content, and panned concentrates contained detectable amounts of gold, but no exploitable deposits were indicated by the analytical data.

\section{INTRODUCTION}

The Glacier Primitive Area (fig. 1), about 50 miles southeast of Yellowstone National Park in western Wyoming, encompasses

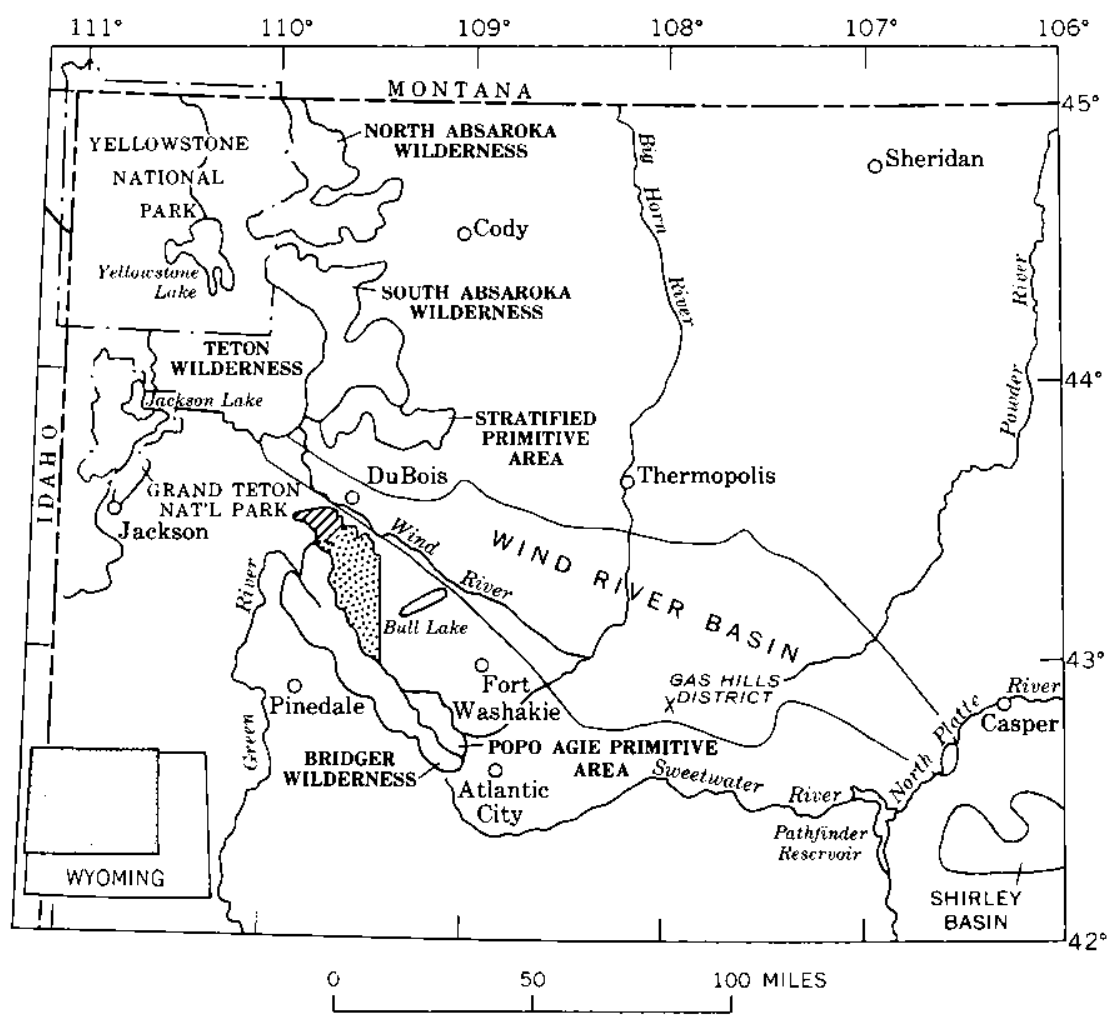

FIgURE 1.-Index map of Wyoming showing area studied: Glacier Primitive Area (stippled) and an adjacent area (hachured). 
a large part of the northeast side of the Wind River Range. Its pristine beauty is typified by alpine peaks flanked by snowfields and glaciers, by cascading mountain streams, and by a myriad of scenic lakes (figs. 2, 3). The primitive area has an elongate triangular outline and includes about 277 square miles of the Shoshone National Forest. Also studied was about 65 square miles of contiguous national forest that extends northwestward from the primitive area. The area studied is bounded on the east by the Wind River Indian Reservation and on the west, beyond the Continental Divide, and south by the Bridger Wilderness. North of the area studied, part of the land is national forest, part is owned by the State, and part is privately held.

Much of the primitive area is dominated, topographically, by remnants of an uplifted peneplain cut on Precambrian crystalline rocks and sharply incised by canyons. Along the southwest border of the area the Continental Divide is characterized by a jagged alpine spine (fig. 4). A line of rounded, partly wooded peaks in the northeast part of the study area is composed of the exposed edges of resistant middle Paleozoic limestones and dolomites which dip northeastward from the flank of the crystalline core of the mountains.

Relief in the area is nearly 7,000 feet, and elevations range from 13,785 feet on Gannett Peak (fig. 5) to about 6,790 feet

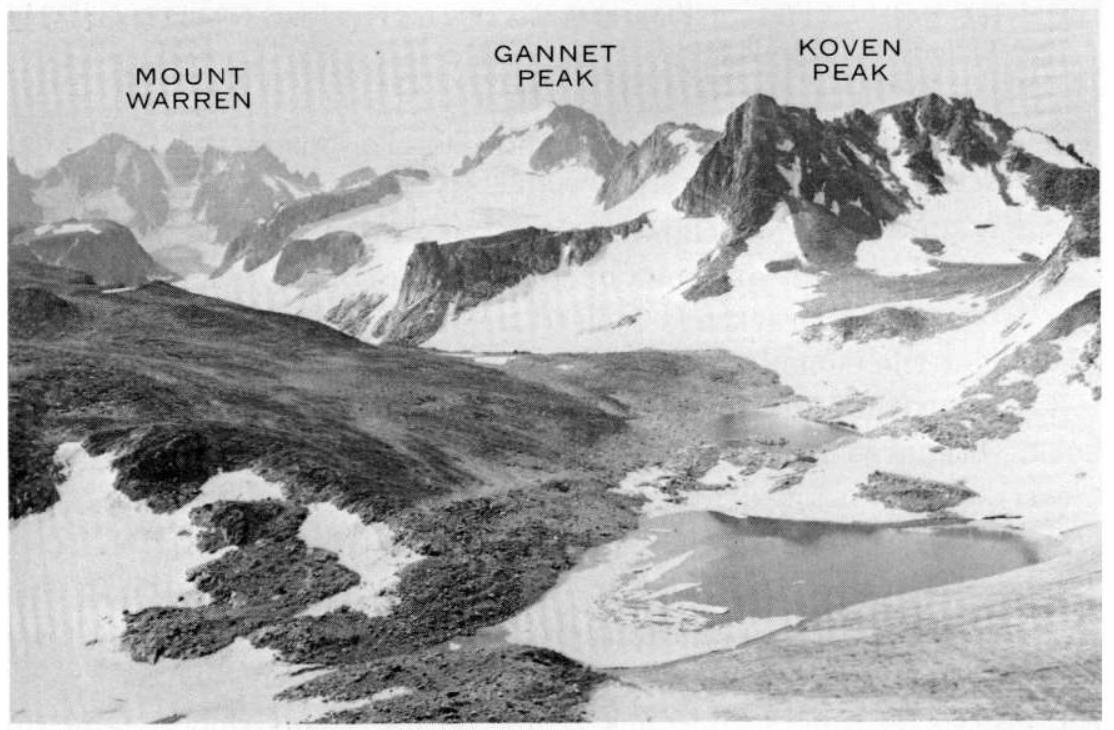

Figure 2.-North side of Gannett Peak as seen from the southern end of Downs Glacier. 


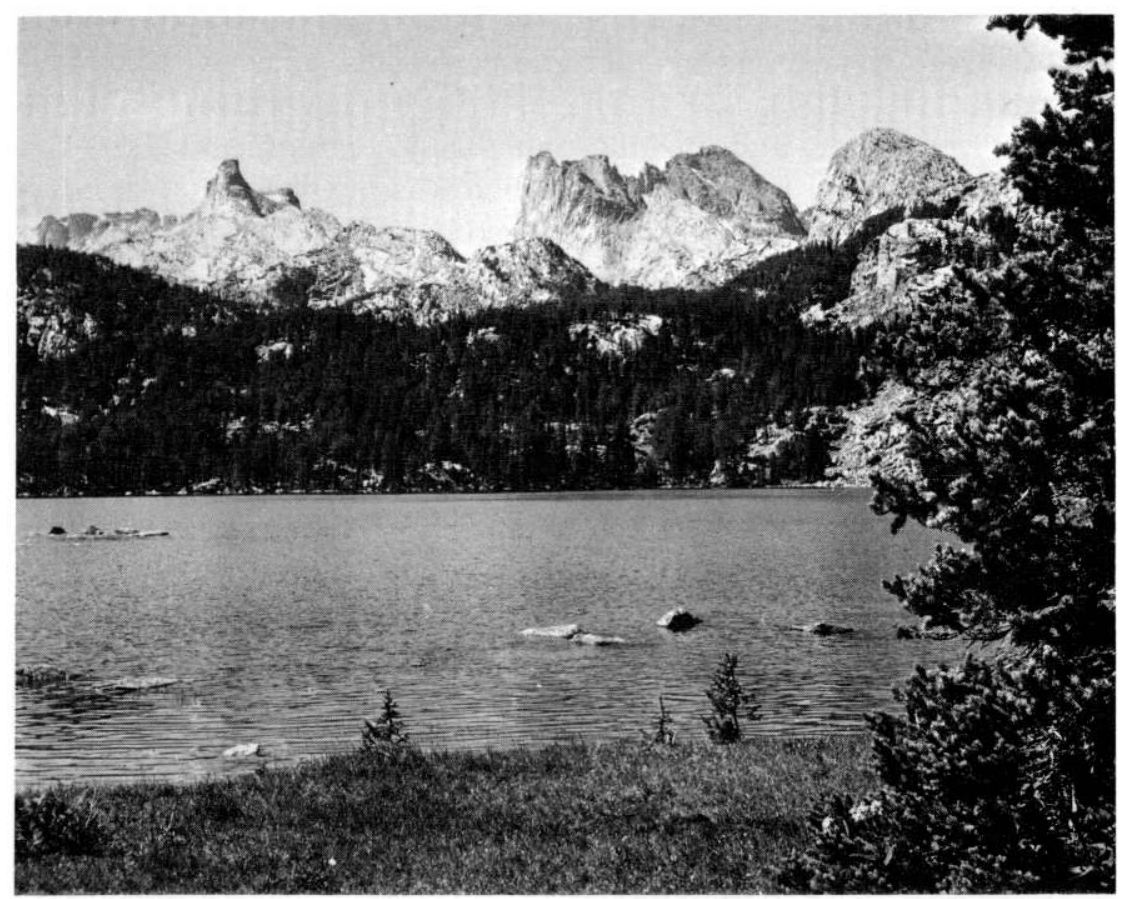

Figure 3.-Two prominent physiographic features: The Fortress on the left and the Brown Cliffs on the right center; riew across unnamed lake in Bull Lake Creek drainage.

where Dinwoody Creek crosses the eastern border of the area. Perhaps the most impressive relief in the area is the drop of about 3,800 feet from Gannett Peak to the base of Gannett Glacier in a horizontal distance of 2 miles. Torrey Creek, Dinwoody Creek, and Dry Creek are incised to depths of as much as 2,000 feet below the peneplain.

Travel within the primitive area is limited to foot and horseback. A sparse network of trails provides access along or near most of the major drainages, but parts of the area cannot be reached by any well-established route. An all-weather dirt road extends from U.S. Highway 287 along Torrey Creek to the primitive area, but this is the only road suitable for passenger cars that reaches the boundary and is probably the principal access route used by hikers and pack trains. Other roads that extend to, or almost to, the edges of the primitive area from Highway 287 are generally suitable only for four-wheel-drive vehicles. Several 


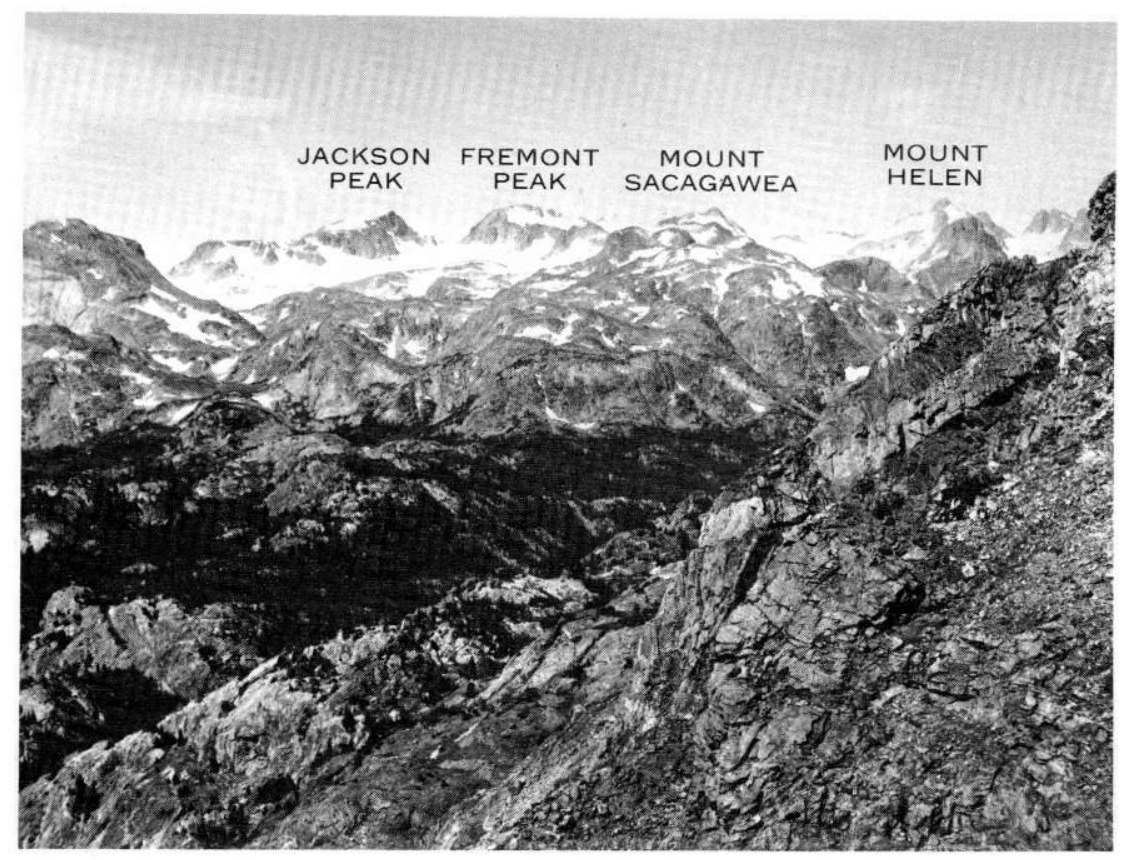

Figure 4.-Crest of the Wind River Range; view looking west from cliffs on the north side of Little Milky Lake. Although mapped as gneiss, the area in the foreground contains granitic and pegmatitic dikes cutting a gneissic sequence which consists principally of biotitic gneiss and includes amphibolite bodies.

of these cross the Wind River Indian Reservation, and permission to traverse them must be obtained from the Indian Agency at Fort Washakie. The northwest end of the study area can be reached by passenger car on the Union Pass dirt road (designated "Lake of the Woods Road" on pls. 1 and 2) during dry weather and by four-wheel-drive vehicles both from roads leading from the Union Pass road and from roads leading from U.S. Highway 287, although access from Highway 287 may require permission from private landowners. There is no established access to the primitive area from the west over the Continental Divide except at and near Hay Pass near the southern tip of the area. Horses reportedly can be taken through Indian Pass between Knife Point Mountain and Jackson Peak but, if this is possible, they must make a hazardous crossing of the Bull Lake Glaciers.

Grasses and sagebrush make up much of the vegetation on nonforested, soil-covered areas up to elevations of about 10,000 feet. 


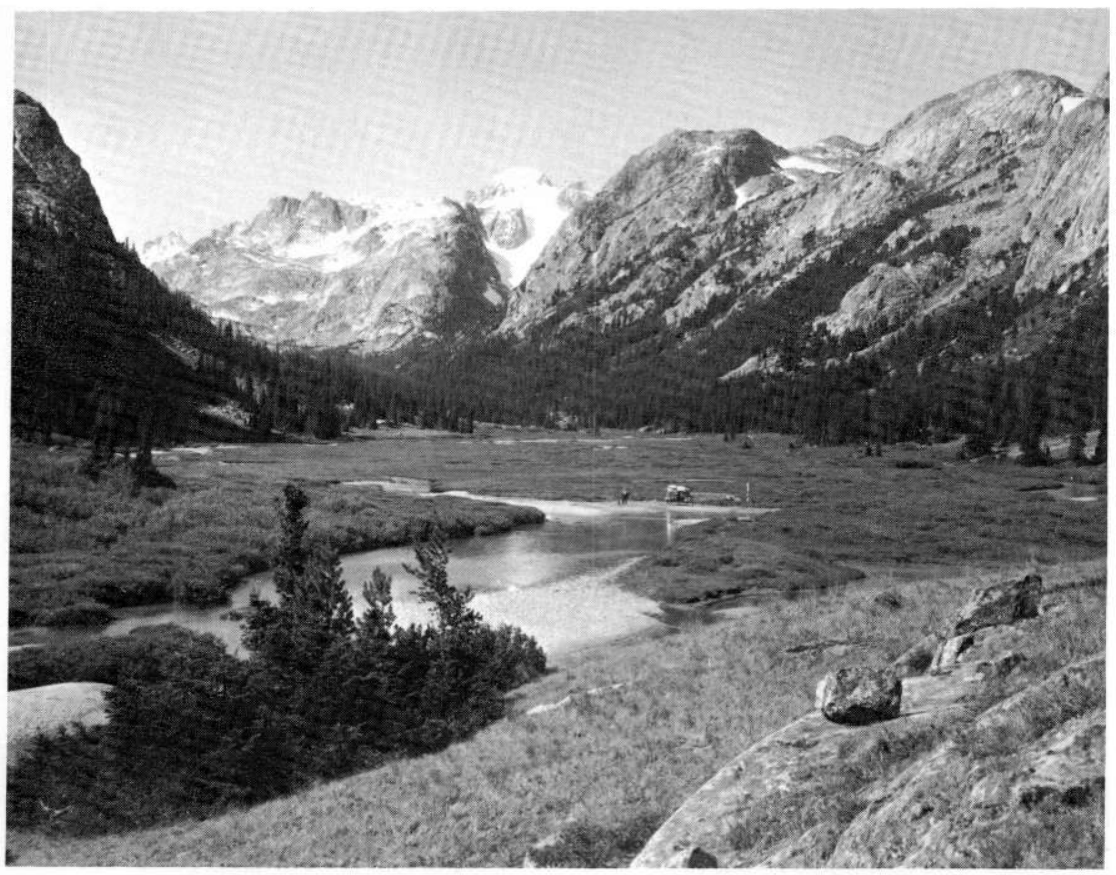

FIgURE 5.-Broad glaciated and alluviated part of the valley of Dinwoody Creek; snow-capped Gannett Peak (elev 13,785 ft) in the central background.

The forested areas contain mostly limber pine, locally mixed with spruce, which terminates very irregularly along a timberline at about 11,000 feet. Alpine willow and other low vegetation grows below and above the timberline particularly along stream courses and marshy meadow and tundra areas.

Independent studies of the mineral resources of the Glacier Primitive Area made by the U.S. Bureau of Mines and the U.S. Geological Survey are combined in this report. The Geological Survey's investigation consisted mainly of geologic mapping and the search for geologic, aeromagnetic, and geochemical evidence that might indicate the presence of or guide exploration for previously unknown deposits. The Bureau of Mines emphasized investigation of mining claims and known deposits.

Mapping and sampling of the study area were done by $\mathrm{H}$. C. Granger and E. J. McKay of the Geological Survey during 11/2 months in the summer of 1968 and 2 months in 1969. D. D. Talbot and G. A. Worf assisted in the sampling in 1968, and Christopher Henry and Duane Packer assisted in both geologic mapping 
and sampling in 1969. A geological reconnaissance map was prepared on the basis of aerial photographs and later compiled on a 1-inch-to-the-mile planimetric base (pl. 1) adapted from U.S. Forest Service quadrangle maps. Results of an aeromagnetic survey of the study area, made in 1969, are also shown on plate 1; the data were interpreted by R. E. Mattick of the Geological Survey.

A geochemical sampling program was conducted concurrently with the mapping. A total of 1,076 samples were collected: 483 rock samples, 470 stream-sediment samples, and 123 panned concentrates.

Fieldwork for the Bureau of Mines in 1968 was done by Paul McIlroy, who was assisted by Lowell L. Patten and, in 1969, by Patten assisted by David R. Alison. The investigation was carried out in three stages: (1) Examination of the records for claim-location notices and affidavits of annual labor, (2) discussion of mining claims with claim owners, Forest Service personnel, and others knowledgeable of mining activity in the area, and (3) onthe-ground examination and samplings of the claims, workings, and mineral deposits.

\section{PREVIOUS WORK}

Although the geology of adjacent and nearby areas has been studied and mapped, very little attention has been paid to the central part of the Glacier Primitive Area. Precambrian rocks in the southern and western parts of the Wind River Range have been much more extensively studied than those on the east flank.

St. John (1883), a member of the Hayden surveys, was among the earliest to describe the geology of parts of the Wind River Range. Much of the early work (Baker, 1912, 1946; Blackwelder, 1911, 1915; Branson and Branson, 1941; Westgate and Branson, 1913) emphasized the Paleozoic and younger rocks and the Cenozoic physiographic history, largely on the west flank of the range.

Richmond (1945) mapped and briefly described the geology of a 430-square-mile area west of the primitive area. Oftedahl (1953) commented on crystalline rocks seen during a reconnaissance of the Precambrian terrane southeast of the area studied by Richmond and west of the Continental Divide.

Graduate theses by Mooney (1951) and Gilliland (1959) described principally the geology of Paleozoic and younger sedimentary rocks that extend northwestward from Torrey Creek. Much of their mapping was within the study area.

Richmond and Murphy (1965) and Murphy and Richmond (1965) mapped the geology of two quadrangles around Bull Lake 
about 10 miles east of the primitive area, emphasizing the glacial deposits. Worl $(1968,1969)$ mapped and described the Precambrian rocks of the Three Waters area (near Triple Divide Peak) which lies largely west of the northern part of the primitive area.

Perry (1965) mapped a sequence of Precambrian metamorphic rocks in the Paradise Basin quadrangle about $4 \frac{1}{2}$ miles east of the southern part of the primitive area. He found that the metamorphic structures and rocks generally trend northwestward. Barrus (1968) traced these same rocks northwestward almost to the east border of the primitive area. Continuing his mapping into the primitive area in 1969 (oral and written commun., 1969), he was able to follow parts of this sequence and its structural trends to the Continental Divide. He generously provided us with some of the results of this study.

J. F. Murphy kindly permitted us to inspect the preliminary results of his mapping, largely in Paleozoic rocks, in the Blue Holes and Hayes Park quadrangles which include about a 2-mile-wide strip of the northeastern part of the primitive area along their western edges. Concurrently in 1969, R. C. Pearson and T. H. Kiilsgaard were conducting a similar mineral survey in the Popo Agie Primitive Area on the east flank of the southern part of the Wind River Range.

\section{ACKNOWLEDGMENTS}

Stimulating discussions and a great deal of useful information were contributed by other geologists who had worked or were working in the region. These include R. B. Barrus, University of Washington; R. C. Pearson, T. H. Kiilsgaard, R. G. Worl, and J. C. Antweiler, U.S. Geological Survey; and Kenneth Perry, Jr., University of Wyoming. Their contributions are greatly appreciated.

Particular thanks are given to Harold Wadley, U.S. Forest Service, and Howard Sanderson, Wyoming Game and Fish Commission, both of Dubois. Mr. Wadley very helpfully provided a fund of information, including details of accessibility to the area. Mr. Sanderson helped us choose a base-camp location (sec. 23, T. 40 N., R. 106 W.) on the Whisky Basin Winter Range from which a helicopter could be operated. Cooperation provided by the Wyoming Game and Fish Commission is deeply appreciated.

The Joint Shoshone and Arapahoe Tribal Business Council of the Wind River Indian Agency kindly granted permission to use a site on Indian land near Bull Lake as a temporary base of heli- 
copter operations in 1969 . We thank the highly competent W. L. Roberts, who owned and operated the helicopter used throughout the 1968 field season. In 1969 the pilots were Monte Johnson, Ben Merrill, and William Sears. We are especially grateful to L. O. Wilch and R. V. Mendes, U.S. Geological Survey, for their diligence and patience in transferring analytical data to computer tape.

\section{GEOLOGY}

\section{GEOLOGIC SETTING AND HISTORY}

The core of the Wind River Range is a complex assemblage of metamorphic and igneous crystalline rocks overlain, on the east side, by northeastward-dipping Paleozoic and Mesozoic sedimentary rocks that aggregate several thousand feet in thickness. These rocks dip into the Wind River Basin where they are covered by a thick succession of Tertiary continental sedimentary units that locally lap onto the flank of the range and partly cover the truncated edges of the older sedimentary sequence as well as the Precambrian rocks.

The present-day Wind River Range was initiated by a broad uplift of the northwestward-trending elongate crystalline core, evidently accompanied by westward thrust faulting (Baker, 1946; Berg, 1961) on the west flank of the range. After the earliest uplift, which occurred largely in Laramide time (Late Cretaceous and early Tertiary), erosion exposed the crystalline core of the mountains and carved a topographically rugged forerunner of the present Wind River Range. Deep canyons such as those of ancestral Jakeys Fork and Torrey Creek were cut into the flanks of the range, and the lower reaches of these canyons were filled in $\mathrm{Pa}-$ leocene(?) and Eocene time with alluvial material derived, in large part, from erosion of older rocks at higher elevations. This period of erosion was followed by mid-Tertiary or later peneplanation that must have reduced much of the range to a region of low relief. Presumably this surface is now represented by relics (figs. 13, 14) such as Goat Flat, Ram Flat, the area along Horse Ridge, and the divide between the headwaters of Dry and Bull Lake Creeks.

The angle between the mid-Tertiary peneplain and the surface on which the Cambrian Flathead Sandstone was deposited is very slight along much of the east side of the range. In fact, the presence of a rather flat-lying outlier of Flathead Sandstone on the Continental Divide just southwest of Simpson Lake suggests that some of the flat surfaces within the primitive area may be fault- 
displaced Lower Cambrian surfaces from which the Flathead has been stripped. West of the crest of the range, however, there seemingly is good evidence for a surface (Fremont peneplain) formed in Tertiary time as noted by Baker (1946) and earlier writers; we have assumed that it is a surface of this age which is now seen on the east side of the range even though evidence is less conclusive there.

Renewed uplift of the range then occurred during one or more episodes after peneplanation; broad arching of the peneplaned surface was accompanied by some block faulting which differentially displaced some parts of the peneplaned surface (probably not exceeding $1,000 \mathrm{ft}$ ) near the crest of the range relative to other parts. Pleistocene glaciers then covered most of the crest of the range and scoured much of the Tertiary filling from the old canyons that emerged from the mountain front.

Since Pinedale Glaciation, in late Pleistocene time, the glaciers have retreated to their present sites high in the cirques and alpine valleys near the crest of the range. About 30 glaciers can now be found in the primitive area; the number depends somewhat on whether merging glaciers are counted as one or several, and whether small perpetual snowfields on cliff and cirque walls are given the status of glaciers. The largest glaciers-about a dozen-originate in cirques and snowfields along the Continental Divide.

\section{PRECAMBRIAN ROCKS}

The Precambrian rocks in the area are divided into two metamorphic terranes by a structural zone that will be referred to as the Mount Helen structural belt (pl. 1). It extends from near Mount Helen on the Continental Divide southeastward toward Alpine Lake, which lies just east of the Glacier Primitive Area. North of this structural belt the central part of the study area is occupied by a north-trending granitic body referred to here as the Middle Mountain batholith. The batholith is about 5 miles wide and 25 miles long, but it continues beneath the Paleozoic sedimentary sequence to the north. The Middle Mountain batholith is gradational into the surrounding gneiss through a migmatite zone characterized in different places by lit-par-lit intrusion, partly assimilated blocks of gneiss, and a network of granitic and pegmatitic dikes.

South of the Mount Helen structural belt, a coarse-grained porphyritic granite body grades northward into migmatite which differs from the migmatite north of the belt. The structural belt 
is characterized by seemingly discontinuous bodies of augen gneiss, porphyritic granite, and other mafic and felsic rocks.

In summary, the crystalline rocks are divisible into two terranes, each dominated by a different granitic rock which grades outward through a migmatite zone into a thick sequence of gneissic rocks. A small area of porphyritic granite, exposed in the extreme southern part of the primitive area, is lithologically similar. to rocks exposed in the Popo Agie Primitive Area 10 miles or more to the southeast.

Radiometric dates of several pegmatite dikes and bordering gneissic rocks near Simpson Lake (Bassett and Giletti, 1963) suggest that the core of the northern end of the Wind River Range underwent a metamorphic event about 2,700 million years ago. These dates, obtained by using both potassium-argon and rubidium-strontium methods, show a spread of age values in various mica and feldspar samples that was interpreted to indicate a subsequent event that considerably lowered some of the apparent ages. Because the pegmatites do not seem to have been affected by any strong metamorphic event since their emplacement, it is likely that the 2,700-million-year figure indicates the age of the pegmatites (and, perhaps, of the Middle Mountain batholith).

The following descriptions of the Precambrian rocks are necessarily brief and generalized. Greater detail and, perhaps, conflicting observations are given by Barrus (1968; unpub. data, 1969) and Perry (1965); their studies, east of the primitive area, were principally directed to the structural zone which separates the two metamorphic terranes.

\section{Gneissic Rocks}

Medium- to coarse-grained, gray gneissic rocks form the framework of the crystalline core of the northern Wind River Range. Well-foliated quartz-feldspar-biotite gneiss is the predominant rock type, although the proportions of these minerals and the compositions of the feldspars vary widely even within short distances. Fundamentally, the types of biotite-bearing gneiss are similar throughout the area, differing largely in the proportions of essential minerals and in the presence or absence of alkali feldspars. Where microcline is present in more than varietal amounts, the accompanying plagioclase is typically albite or sodic oligoclase, and there is some suggestion that these rocks are rather near one of the large granitic bodies. Where microcline is absent, the plagioclase is typically oligoclase or sodic andesine; these rocks generally seem to be farther from granitic bodies. 
A typical specimen of gneiss has a quartz-diorite composition and contains about 30 percent quartz, 45 percent plagioclase, and 15 percent yellow-brown biotite. Hornblende is present locally in amounts as large as 5 percent of the rock. The accessory minerals---apatite, zircon, sphene, magnetite--and alteration(?) minerals such as epidote, clinozoisite, chlorite, and sericite make up the remainder. Gneiss of more granitic composition typically contains about 25 percent quartz, 35 percent microcline, 30 percent plagioclase, and 5 or 10 percent biotite; the accessory and alteration minerals are similar to those of the gneiss of quartz-diorite composition.

Foliation is mainly defined by streaking and alinement of biotite and hornblende, although there is also some tendency for alinement of the lighter colored minerals, particularly in rocks showing an incipient development of augen structure. Under the microscope, quartz grains typically show an undulatory extinction that indicates strain, but granulation resulting in mortar structure is much less common.

The biotitic gneiss encloses variously shaped discontinuous bodies of amphibolite, biotite schist, metadiabase, and other metamorphosed intrusive rocks, and a few scattered ultramafic bodies. Perhaps more common are lenses, blocks, and boudins of fine- to coarse-grained amphibolite that are a few inches to hundreds of feet across and contain various proportions of green hornblende, calcic plagioclase, and minor quartz. The smaller bodies form concordant lenses and boudins in the gneiss; the larger are agmatitic masses that are laced with dikes and veins of pegmatite (fig. 6) and quartz-plagioclase rock. Lenses of biotite schist are less common. Some of these lenses locally contain disseminated pyrite and are iron stained at the surface. Other elongate bodies that are abnormally rich in either hornblende or biotite are traceable for as much as a few hundred feet along the strike of foliation. All these rocks have been metamorphosed and may variously have originally been carbonate-rich graywacke in a sedimentary sequence, mafic sills and dikes, or metamorphic segregations. For the most part, these rocks occur only north of the Mount Helen structural belt and are most abundant around the southern part of the Middle Mountain batholith.

Foliation in the gneiss is commonly erratic and may be highly contorted, particularly in and near migmatite. It is most consistent in the southern part of the primitive area near the Mount Helen structural belt where it trends generally northwest and dips to the northeast. Along the east side of the Middle Mountain 


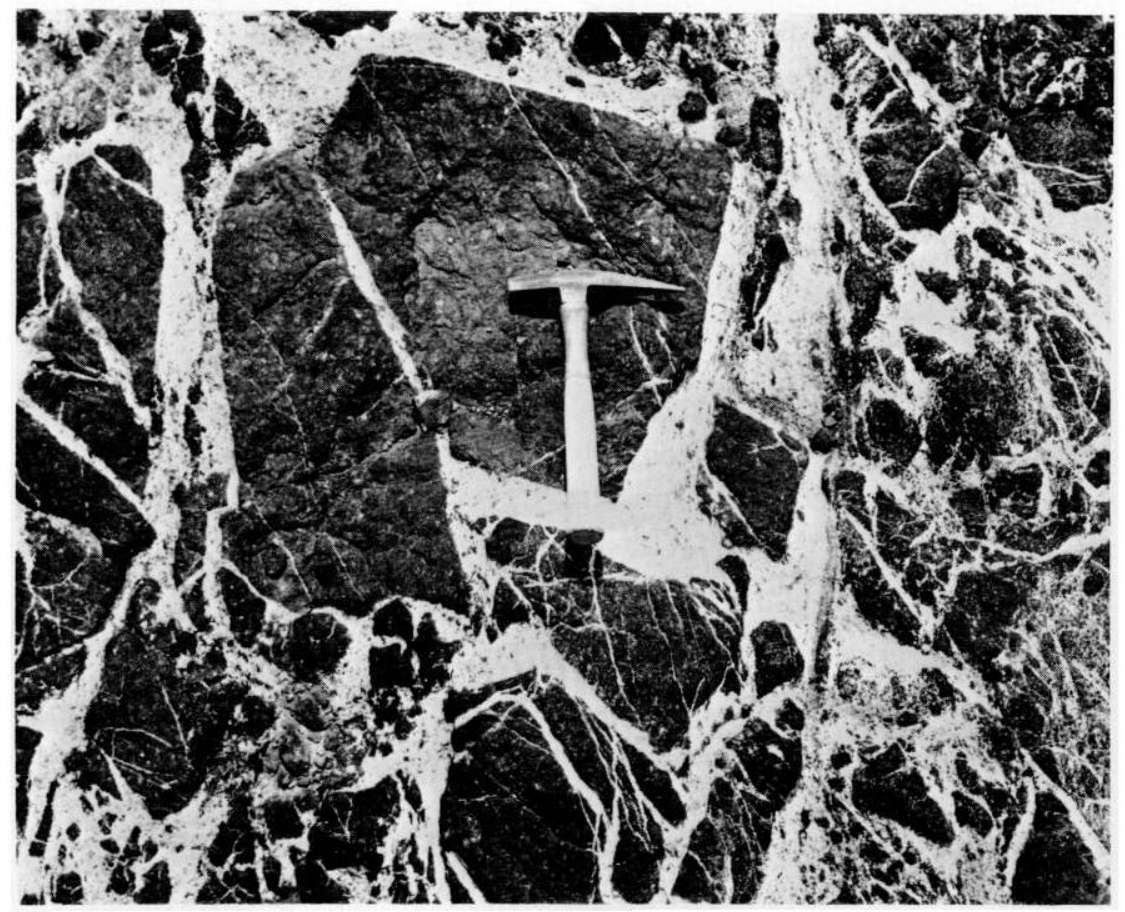

Figure 6.-Part of a brecciated amphibolite (agmatite) block included in migmatite, showing the intricate pattern of cementation by pegmatite. Photograph taken in sec. 32, T. 36 N., R. 106 W.

batholith, the foliation turns more northward and tends to dip steeply to the east. Near Simpson Lake there are local areas of generally consistent foliation which trends northeastward and dips west to north on the west side of the lake and strikes northwestward and dips northeast on the east side of the lake. No large folds were recognized, although small-scale drag folds of various attitudes were seen.

The gneissic masses within the study area give no good evidence of their origin, but their composition indicates that they were probably arkoses and graywackes for the most part. Metamorphosed iron-formation was identified by Worl (1969) in gneiss less than 2 miles west of Downs Peak. Perry (1965) and Barrus (1968) described sillimanitic paragneissic bodies that trend toward the primitive area from the east.

A few scattered discontinuous layers and lenses of mafic rock included in the gneiss are identified as metadiabase masses which were probably intruded as sill-like bodies prior to the last metamorphic events. They were intruded into rocks that had already 
been considerably metamorphosed, as is indicated by the fact that the diabasic texture is still recognizable even though the enclosing gneiss retains none of its original textures. (See also Worl, 1968.)

The gneiss in this area seems to have been uniformly metamorphosed to amphibolite facies. No convincing evidence was found for granulite-facies metamorphism as described by Perry (1965) a few miles to the east and by Worl (1968) on the west.

\section{Ultramafic Rocks}

Small semiconcordant bodies of ultramafic rock are scattered through the gneiss, particularly in the drainages of the North Fork of Bull Lake Creek and Dry Creek. A few were mapped (pl. 1), but others were too small or obscure, and some were believed to be amphibolites until their identity was shown under the microscope. The bodies are generally only a few tens to a few hundreds of feet long and a few feet wide; they are lenticular and parallel to the foliation, although some have irregular shapes and orientations. The fresh rock is dark gray, but weathered surfaces and immediately surrounding rocks are commonly iron stained. For the most part, these rocks are fine to medium grained, and fresh surfaces appear flaky or felted. Veinlike zones, particularly near the margins of the ultramafic bodies, may be much coarser grained and consist principally either of large greenish tremolite crystals parallel to the vein walls or of cross-fiber anthophyllite. The ultramafic bodies, which contain no feldspar or quartz, are lithologically distinct from the many amphibolite bodies, which are typically coarser grained and contain both plagioclase and quartz.

Under the microscope, it can be seen that the ultramafic rocks vary somewhat in composition from body to body but are typically a fine-grained hypidiomorphic granular aggregate of tremolite and various proportions of clear olivine and enstatite. A very pale brown mica, probably phlogopite, may be sparsely present, and some specimens contain scattered green spinel as inclusions in all the other minerals. Feldspars are absent from all specimens examined except for a small very coarse grained body of anorthosite associated with one of the ultramafic bodies northwest of Native Lake.

Alteration minerals are universally present and commonly replace nearly all the earlier minerals. Talc, serpentine, and chlorite are common. Magnetite and perhaps ilmenite and chromite generally accompany the other alteration minerals, although they may be in part relict minerals. Talc and chlorite are also fairly com- 
mon in many fault zones within the study area, but these minerals also occur in some of the ultramafic bodies well away from the obviously faulted areas. Presumably, therefore, the alteration minerals in some of the ultramafic rocks are the result of a retrograde metamorphism unrelated to faulting.

\section{Migmatite}

The migmatite zone that surrounds the Middle Mountain batholith differs from that which occurs south of the Mount Helen structural belt and will be described separately. Migmatite marginal to the Middle Mountain batholith consists partly of mixed foliated rocks into which granitic rocks were injected while the gneiss was in a plastic state and partly of agmatite which appears to be coarse breccia into which granitic and pegmatitic phases were complexly intruded as dikes and vein networks (figs. $7,8)$. Foliation is typically swirly and chaotic, and minor folds

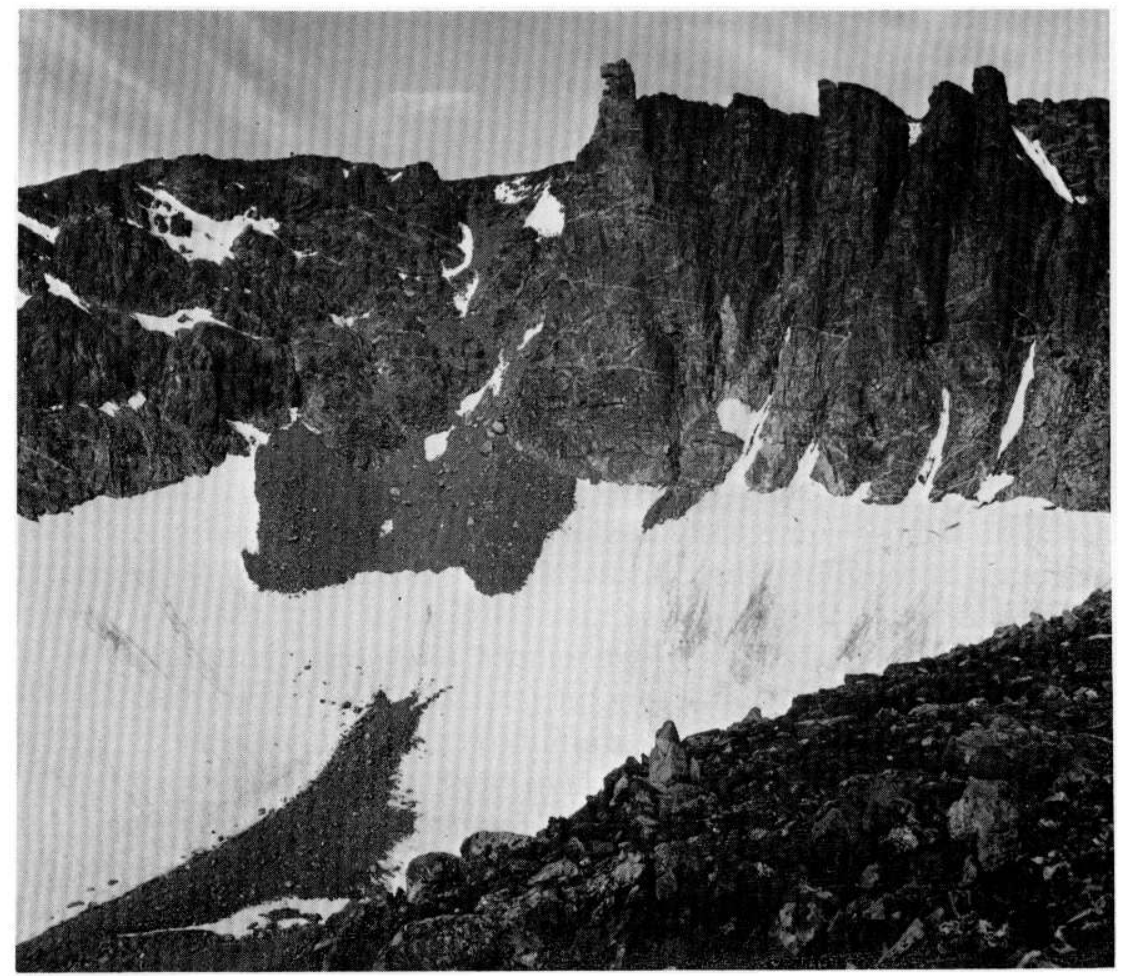

Figure 7.-Chimney Rock, a landmark along the south edge of upper Horse Ridge. Note the network of granitic and pegmatitic dikes in the gneiss and amphibolite that form the cliff walls. 


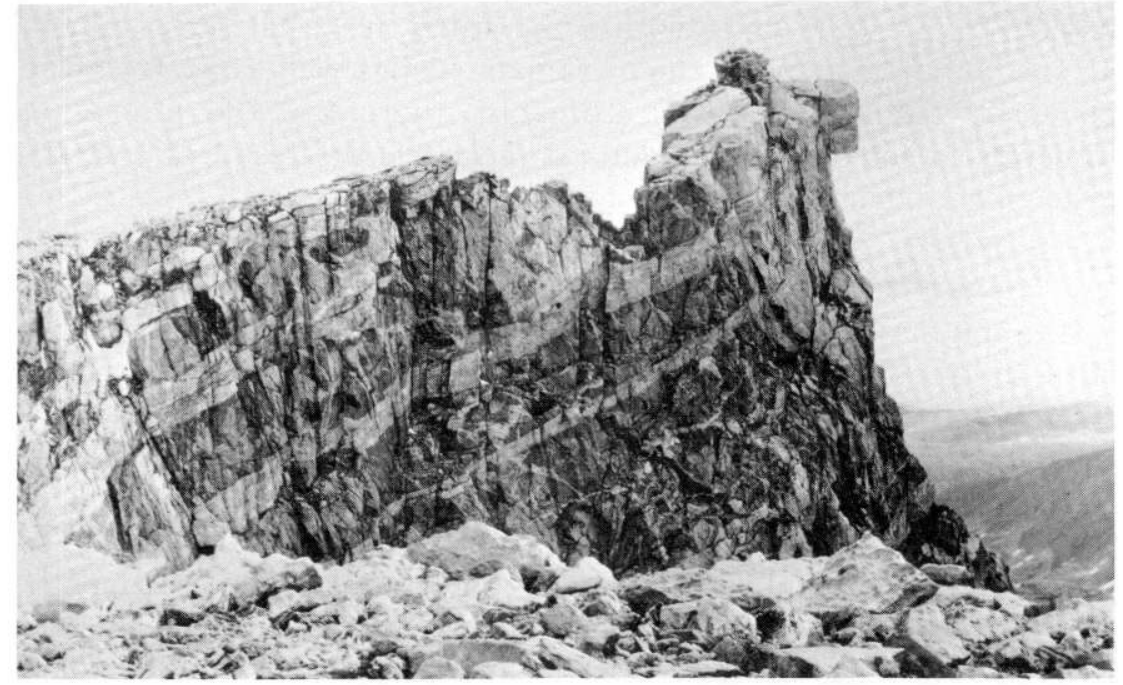

FiguRe 8.-Closeup of Chimney Rock from Horse Ridge. Light-colored gently dipping granitic dikes cut across the more steeply dipping gneissic foliation.

may or may not be common. Bodies of amphibolite that may be metamorphic segregations seem to be more abundant in the migmatite zone bordering the southern parts of the Middle Mountain batholith, but whether this is a characteristic of the migmatite or merely a compositional property of the preexisting gneissic sequence was not determined.

Although approximately located contacts between the migmatite and adjacent rocks are shown on plate 1 , the migmatite nearly everywhere has broadly gradational margins. Ghosts and relics of almost completely assimilated or transformed gneiss can be found throughout the Middle Mountain batholith but, near the migmatite zone, these become more prevalent and less thoroughly assimilated and ultimately grade into migmatite. Amphibolite is more resistant to assimilation in granite than is the more felsic gneiss, so the abundance of amphibolite bodies may locally seem to be exaggerated along the gradational boundary between granite and migmatite. The contact between migmatite and gneiss is also gradational and was arbitrarily placed where swirly and chaotic foliation, injected gneisses, and dike networks become insignificant features of the gneissic terrane.

A large area in the upper Dinwoody and Dry Creek drainages has been mapped as gneiss and migmatite intruded by a felsic dike network. This is a poorly defined area in which large num- 
bers of granitic and pegmatitic dikes (figs. 7,8 ) form a meshlike network in the gneissic and migmatitic host rocks. The contact between these rocks and the Middle Mountain batholith is highly irregular and gradational through a broad zone containing large bodies of partly assimilated gneiss, migmatite, and amphibolite engulfed along the margins of the batholith.

North of the Jakeys Fork fault, granite grades westward into rocks that might be mapped in places as either migmatite or gneiss. Locally, the foliation is highly contorted; both granitic and pegmatitic phases were injected, while the gneisses were in a semiplastic state, as lit-par-lit bands a fraction of an inch to several feet wide and as swirly crosscutting masses. These are certainly migmatitic rocks. Much of the rock, however, appears to be well-foliated gneiss and was mapped as such, even though more detailed wrork would undoubtedly allow delineation of units of migmatite. Similarly, migmatite might be mapped adjacent to the granite body near Granite Lake and at several places along the Continental Divide west of Union Peak. Our work was not sufficiently detailed to define migmatite in these areas, however.

Migmatite bordering the porphyritic granite at the south end of the primitive area is distinct from the migmatite to the north. This migmatite was formed almost entirely while the gneiss was semiplastic. Granitic and pegmatite dikes occur locally throughout the migmatite but may be later than and unrelated to the porphyritic granite. The migmatite consists of typical quartz-plagioclase-biotite gneiss into which a speckled hornblende-biotite granodiorite has been complexly injected. The speckled appearance is caused by scattered discrete aggregates of hornblende, or biotite, or mixtures of the two. Scattered hornblende grains and aggregates one-eighth to three-eighths inch across are, perhaps, the most typical and diagnostic feature of this once-mobile phase of the migmatite. Large microcline phenocrysts become less abundant at the margins of the granite masses and finally disappear as the gneissic phase becomes prevalent in the migmatite. Although biotite is the most abundant mafic mineral in most of the granite, it typically gives way to hornblende or hornblende-biotite aggregates as the microcline phenocrysts decrease in abundance. The speckled phase steadily decreases, and the nonmobile gneissic phase increases proportionately with distance from the granite. Adjacent to hornblende amphibolite bodies, the speckled phase commonly contains a greater abundance of the hornblende aggregates derived, as if by attrition, from the amphibolites. Locally, the gneissic phase has been brecciated and cemented by the speck- 
led mobile phase (fig. 9), but in most places the speckled phase was complexly and intimately injected into the gneiss (fig. 10) almost as if squirted into a sponge. Foliation of the gneissic phase is commonly contorted, although it strikes predominantly to the northwest in northern parts of the migmatite zone.

The speckled phase typically consists of about 15 percent quartz, 10-15 percent aggregates of hornblende and biotite, and

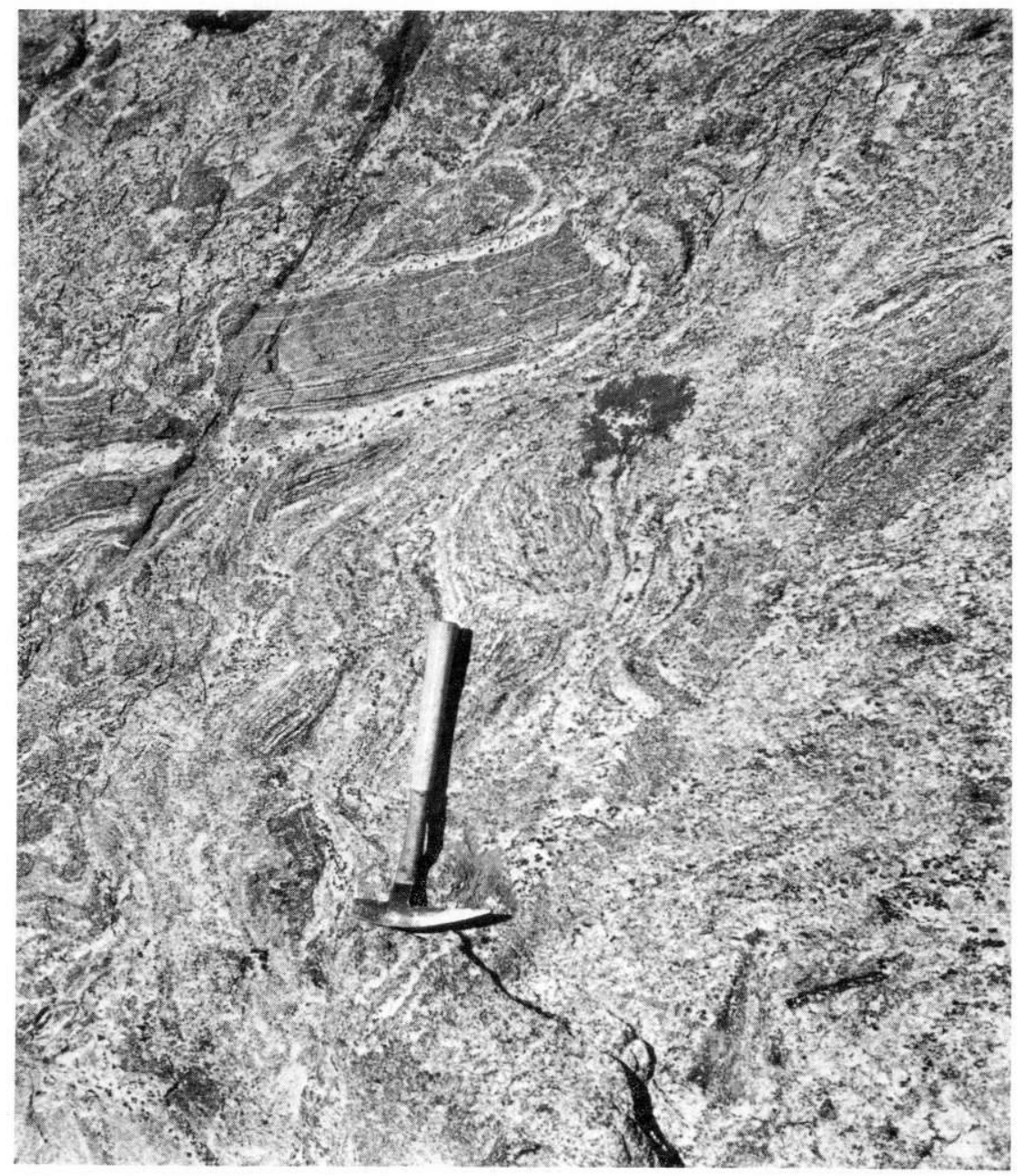

Figure 9.-Migmatite in sec. 3, T. 1 S., R. 6 W., showing disoriented blocks of biotite-quartz-feldspar gneiss swirled in the speckled hornblende phase of the porphyritic granite. 


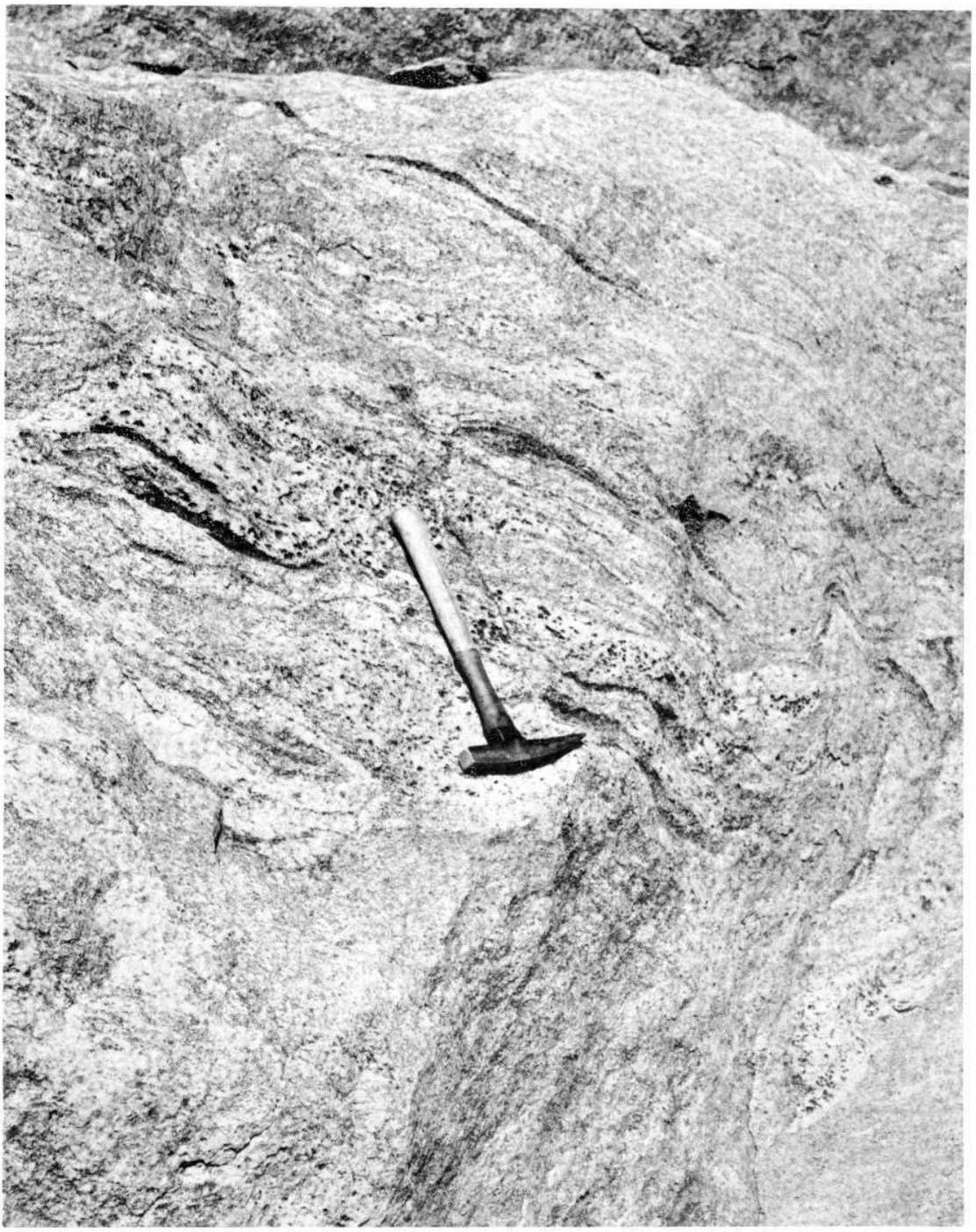

Figure 10.-Migmatite on Mount Quintet showing the speckled hormblende phase of the porphyritic granite injected into biotite-quartz-feldspar gneiss.

about 65-70 percent microcline and calcic oligoclase. Commonly, microcline is about 40 percent and plagioclase about 30 percent. As much as 5 percent of the rock may be sphene, apatite, magnetite, and epidote.

The gneissic phase typically contains 20 percent quartz, 15-20 percent biotite, and no hornblende. Feldspar makes up about 60 
percent of the rock. The plagioclase is andesine or calcic oligoclase if microcline is virtually absent, whereas if microcline is present the plagioclase is calcic oligoclase and constitutes about 40 percent of the rock. The gneissic phase seems to be similar to the gneiss farther north and to the gneissic phase of the migmatites bordering the Middle Mountain batholith.

\section{Mount Helen Structural Belt}

The northern limit of the migmatite in the southern part of the primitive area is defined by the Mount Helen structural belt, a sinuous belt of foliated rocks containing broad bands of uniformappearing light-colored gneisses, discontinuous(?) layers of augen gneiss, and irregular intrusive bodies of both porphyritic granite and the speckled phase of the migmatite. Within this vaguely defined band, which is about a quarter of a mile wide, the gneiss maintains a rather consistent northwest strike and northeast dip.

The belt crosses the eastern boundary of the primitive area near the junction of Bull Lake Creek and the Middle Fork of Bull Lake Creek and extends northwestward toward the headwaters of the North Fork of Bull Lake Creek where it is cut by the Alpine Lakes shear zone (the amount of displacement was not measured). The belt appears to cross the crest of the range on the north flank of Mount Helen.

The consistent foliation, the augen gneiss, and the intrusive bodies of porphyritic granite and related rocks which occur in this seemingly continuous band all suggest a structural origin for the zone. This zone is referred to herein as the Mount Helen structural belt in the belief that it represents a structurally disturbed zone predating all the faults, lineaments, and shear zones which were mapped in the area.

In an area a few miles east of the primitive area, Barrus (1968) defined a northwest-trending belt of augen gneiss paralleled by a wider belt of orthogneiss on the southwest. These belts separate gneiss on the northeast from migmatite to the southwest and project northwestward toward the Mount Helen structural belt. Reconnaissance mapping in the primitive area failed to prove the existence of such well-defined rock units as Barrus mapped, but there is little doubt that the Mount Helen structural belt represents the continuation of similar geologic features.

Barrus (1968) proposed that the augen gneiss might represent a former extensive dacite flow that formed long before the metamorphic events or, alternatively, a recrystallized shear zone bor- 
dering rocks to the south. The shear-zone concept better explains the termination of migmatite and the scattered intrusive bodies of porphyritic granite along the trend.

\section{Granite of Middle Mountain}

The Middle Mountain batholith is a northward trending body about 5 miles wide and 25 miles long in the central part of the study area. The body is composed of granitic rocks that are heterogeneous in texture but generally similar in composition. Perhaps the most characteristic rock type is gray to pale-pink biotite granite containing scattered, randomly oriented microcline phenocrysts. The phenocrysts are typically one-fourth to three-eighths inch in length; even somewhat larger phenocrysts are rather inconspicuous except under conditions where cleavage faces reflect the light. In many places-Goat Flat, for example-the porphyritic-granite phase grades into and out of a simple pegmatitic phase. Few pegmatite areas are more than a few feet across and a few tens of feet long. The pegmatites form no well-defined bodies, and obviously both phases formed contemporaneously.

A more equigranular gray granite, similar in composition to the porphyritic granite, is also abundant. No distinct separation between these phases was noted, and they are intermixed throughout much of the batholith. Most granitic dikes that intruded the surrounding migmatite seem to be similar to this equigranular phase, although they generally have a pinkish cast and have a grain size as small as aplite material, particularly in the narrower dikes.

Other granites are present locally, but it was not determined whether these represent genetically discrete intrusions or whether they are merely local variants of the batholith. An area of slightly finer grained pink granite was noted along the south side of Louise Lake, for example, but no attempt was made to map it.

In and near several fault zones, the feldspar is pink and the biotite is altered to green chlorite and epidote, making a rather colorful rock. In some places the granite also seems to contain abnormal amounts of quartz in the fault zones. We believe that these red and green hues and silicified areas are caused by alteration near the faults, although Worl (1968) reported later red granites that seem to have intruded faults west of the primitive area.

In addition, some of the granite is red owing to weathering during or after development of the peneplain surfaces. Granite 
underlying the Flathead Sandstone is pink or red in many places to depths of 100 feet or more, and similar colors are prevalent at least as far below some surfaces that have been called a part of the mid-Tertiary peneplain. Some of the red color may be iron stain leached from the overlying Flathead, but much of it is probably due to iron oxide from weathering of mafic minerals in the granite.

The quartz content ranges only from 20 to 30 percent in most phases in the granite of Middle Mountain, but proportions of other minerals vary more widely. Microcline is commonly perthitic and generally constitutes $20-50$ percent of the rock. Albite or oligoclase commonly is clouded with sericite and makes up about 15-40 percent of the rock. Biotite is the most common mafic mineral and makes up as much as 15 percent of the rock, but locally it may be sparse or absent. Some of the biotite is variously greenish brown and yellowish brown under the microscope, but this is much less common than pleochroic green varieties. Hornblende was seen only adjacent to amphibolite inclusions. Alteration and accessory minerals, typically making up less than 5 percent of the rock, are magnetite, zircon, apatite, epidote, chlorite, and sericite. Although most of the granitic rock is equigranular or porphyritic, some of the rock exhibits mortar structure.

\section{Porphyritic Granite}

Only two lobes of porphyritic granite project into the southern part of the Glacier Primitive Area (pl. 1), but these may be parts of a much larger body or bodies of granitic rock to the south. This granite is light gray and contains large microcline crystals that are especially prominent where the cleavage faces reflect sunlight. The rock is similar to and may correlate with porphyritic quartz monzonite in the Popo Agie Primitive Area about 10 miles to the southeast (R. C. Pearson and T. H. Kiilsgaard, oral commun., 1969).

The porphyritic granite is easily recognized by the sparse to abundant microcline phenocrysts (or porphyroblasts?) which occur throughout and which may reach 1 inch across and 2 inches long and locally make up more than 50 percent of the rock. These crystals are generally randomly oriented but in some places are crudely alined, giving the rock a distinctly gneissic appearance. The border facies of the granite-and the related speckled phase in the adjacent migmatite-has mortar structure and strained quartz, which can be readily seen in thin section. Presumably, the mortar structure-finer granulated grains that form a "mortar" 
between the normal grains throughout the fabric-was created by semifluid movement as a crystal mush late in the cooling history of the rock.

A typical specimen of porphyritic granite contains about 20 percent quartz; 20 percent microcline, partly as phenocrysts and partly as interstitial material in the granulated or crushed areas; 40 percent sodic oligoclase or albite; and 15-20 percent combined brownish-green biotite and green hornblende, biotite generally exceeding the hornblende. As much as 5 percent combined magnetite, epidote, sphene, and apatite may be associated with the mafic minerals.

The porphyritic granite grades into migmatite, as noted above, where the phenocrysts are absent and where hornblende is typically more abundant than biotite. No bodies of porphyritic granite more than a few feet across were noted in the migmatite zone but, in the area of the Mount Helen structural belt, there are several much larger but indistinctly defined bodies of porphyritic granite. These may be similar to Barrus' (1968) orthogneiss, although he reported the large crystals, or "porphyroclasts," in the orthogneiss to be plagioclase.

\section{Other Granitic Bodies}

A body of granitic rock similar to the granite of Middle Mountain is exposed near Granite Lake west of the primitive area and southwest of Simpson Lake. Presumably the lake's earlier name, Red Granite Lake, was derived from red weathered granite beneath the Flathead Sandstone outlier nearby. At least a part of this granite body appears to be identical to porphyritic parts of the granite of Middle Mountain, and they are probably genetically related.

A body of equigranular medium-grained gray granitic rock occurs in the migmatite at the NE cor. sec. 5, T. 35 N., R. $106 \mathrm{~W}$. It appears to be distinct from the mobile phase of the migmatite but was not mapped or studied during this investigation.

Two poorly defined bodies of sodic granite or albitite were noted but not mapped. One of these is near the middle of sec. 34, T. $37 \mathrm{~N}$., R. $106 \mathrm{~W}$., and the other is in the W1/2 sec. 33 , T. 36 N., R. $106 \mathrm{~W}$. They are equigranular, medium-grained, albitechlorite-quartz rocks that may be small stocklike bodies only a few hundred feet across. However, because the chlorite seems to have been derived from earlier biotite and both bodies are adjacent to chloritized fault zones, they may merely represent highly altered soda-metasomatized gneiss and migmatite. 


\section{Pegmatite Bodies}

Pegmatite bodies are common in the Precambrian rocks throughout the study area, but most are small, discontinuous, and randomly oriented. Only in the area near Simpson Lake and Union Peak, in the northwest part of the study area, were they considered to be of sufficient size and continuity to warrant mapping.

The pegmatites that can be mapped are all in the form of steeply dipping, parallel-walled dikes; some are as much as 50 feet wide and half a mile long, although most are only traceable for much shorter distances. For the most part, they trend eastward. No rare or valuable minerals were recognized in these simple granitic pegmatites, although Worl (1968) reported one beryl crystal in a pegmatite just west of the primitive area.

Most of the large pegmatite dikes contain abundant pale-red microcline which gives an overall pink cast to the rock. Only a few large dikes contain white feldspar, which is more common in the small dikes. Either biotite or muscovite, in books as much as a few inches across, may be present, but biotite is more common.

Smaller randomly oriented pegmatite bodies occur throughout all the Precambrian rocks with the exception of diabase and perhaps some of the ultramafic rocks. Networks of pegmatitic stringers commonly cut the larger amphibolite blocks enclosed in gneiss, and both pegmatite and granite dikes are abundant in rocks surrounding the southern end of the Middle Mountain batholith.

Most pegmatite bodies seem to have had little if any effect on the wallrocks, but several were noted in which the gneissic foliation of the country rock was dragged or contorted for a few inches from the contact. The country rock must have been semiplastic at the time of pegmatite emplacement.

\section{Diabase}

Three types of diabase were recognized within the study area. Only the oldest of these was metamorphosed. The metamorphosed diabase forms sparsely distributed small bodies that have been stretched to boudinages and altered by the metamorphism in the gneiss. (See also Worl, 1968.) Following metamorphism two lithologically distinct varieties of diabase were intruded as dikes into the metamorphic rocks: a glomeroporphyritic type and an equigranular type. The glomeroporphyritic diabase, apparently the older, forms a southwestward-trending dike that is about 25 feet wide and is traceable for at least 7 miles to where it crosses the 
Continental Divide (pl. 1). A short segment of similar rock was mapped along the south edge of a lake in sec. 1, T. 38 N., R. 106 W., and, if it is a faulted segment of the same dike, the total length of the dike is more than 9 miles.

The glomeroporphyritic diabase is a dark-gray, fine-grained rock that weathers to a weakly iron stained surface speckled with nearly white to gray clusters of phenocrysts mostly less than one-fourth inch across. Under the microscope the phenocrysts are seen to be zoned labradorite laths set in a diabasic groundmass of finer plagioclase laths, pyroxene, magnetite, and alteration minerals. A few scattered altered olivine crystals are larger than most of the groundmass material but smaller than the plagioclase phenocrysts. The groundmass minerals in all specimens collected were partly altered to a variety of fine-grained minerals that were not identified.

The equigranular diabase dikes differ widely in trend and length. Several of them strike northwestward and seem to dip steeply to the southwest. The longest dike is as much as 130 feet wide where it crosses Goat Flat (fig. 11) and is traceable both northwestward and southeastward completely across and well outside the primitive area boundaries - a total distance of more than 30 miles. The few other diabase dikes are traceable for much shorter distances and are less than 50 feet wide.

The equigranular diabase differs from the glomeroporphyritic diabase in having a normal diabasic or subophitic texture grading into intersertal textures along the chilled margins and in lacking olivine. The fresh rock is composed mostly of labradorite laths, augite, and magnetite; a little brown biotite and sparse apatite are present in most specimens. All the dikes, especially the chilled margins, are partly altered. Augite is partly converted to green fibrous uralitic hornblende or chlorite or both. Labradorite is clear and fresh in many places but locally is sericitized or saussuritized(?) or both. A few aggregates of alteration minerals containing scattered magnetite grains might once have been olivine, but no fresh olivine was recognized.

Unfortunately, the projected intersection of the Goat Flat equigranular dike and the glomeroporphyritic dike is not exposed. If the short segment of glomeroporphyritic diabase in sec. $1, \mathrm{~T}$. $38 \mathrm{~N}$., R. $106 \mathrm{~W}$., is, indeed, a faulted part of the larger glomeroporphyritic dike, the diabase of Goat Flat is the younger of the two, as it is not similarly offset by faulting in this area.

Age determinations have not been made on the diabases in the northern part of the Wind River Range, but Condie, Leech, and 


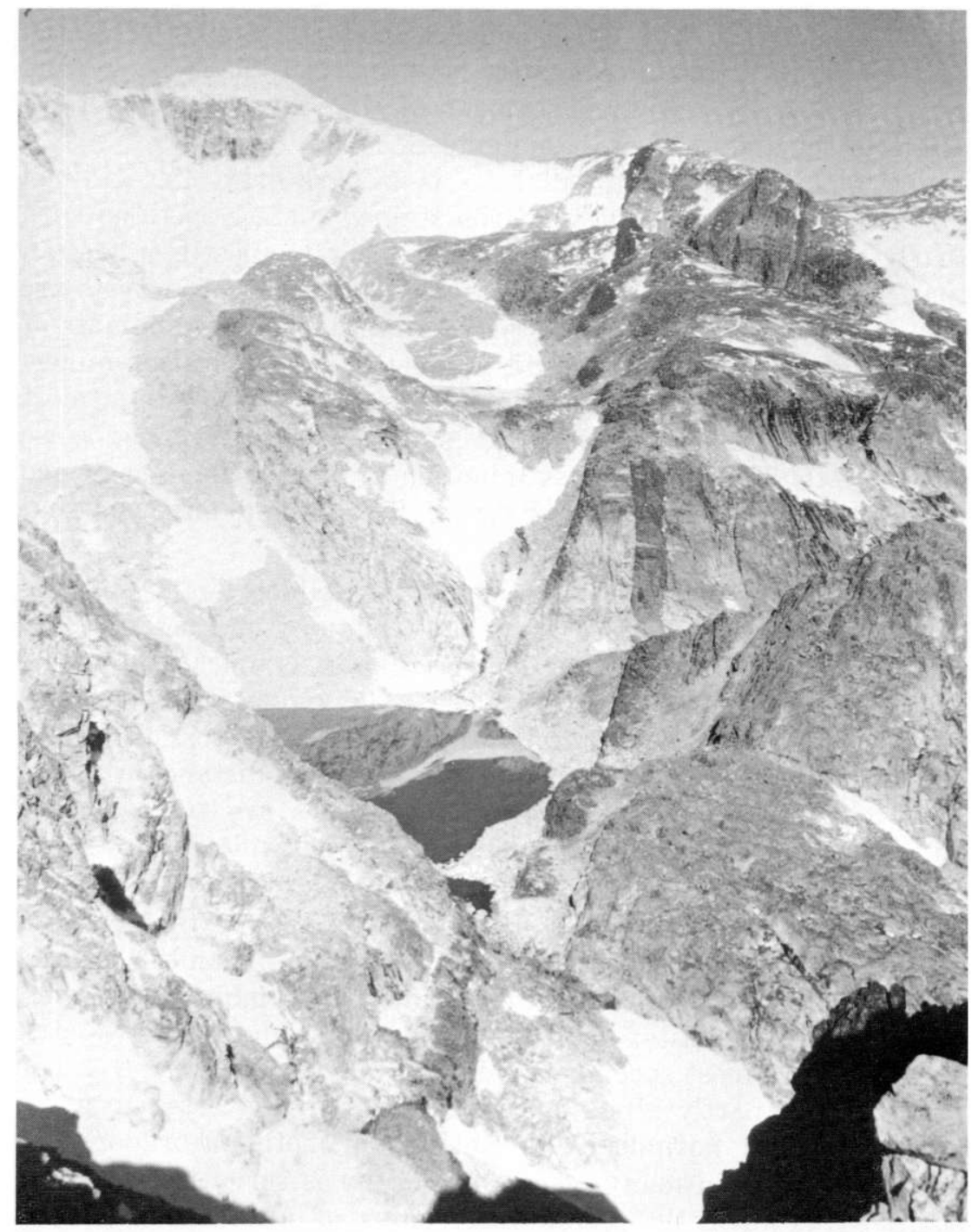

Figure 11.-Diabase dike viewed northwestward from Goat Flat along the strike of the dike. Note split in dike, which merges again between lake and point from which photograph was taken.

Baadsgaard (1969) reported the results of potassium-argon dating of mafic dikes (mostly tholeiitic diabases) in the southern part of the range near Atlantic City. Although these ages range from 900 to 2,060 million years those authors suggested that chloritization was responsible for the anomalously low ages of two of the samples. The remaining samples then fit into two 
groupings which those authors suggested may represent periods of intrusion of Precambrian mafic dikes in Wyoming: one period $1,900-2,200$ and another $1,400-1,800$ million years ago.

\section{PALEOZOIC ROCKS}

A broad band of sedimentary rocks of Paleozoic age dips northeastward from the flank of the crystalline core of the mountains (fig. 12) in the vicinity of the study area. These were deposited mainly in a marine environment and consist of a nearly conformable sequence of well-indurated limestone, dolomite, sandstone, and shale that is separated into nine geologic formations. The thickness of this sequence seems to vary from place to place but probably averages about 3,000 feet. Thicknesses of individual formations given in the descriptions that follow are highly generalized; measured thicknesses are shown in table 1.

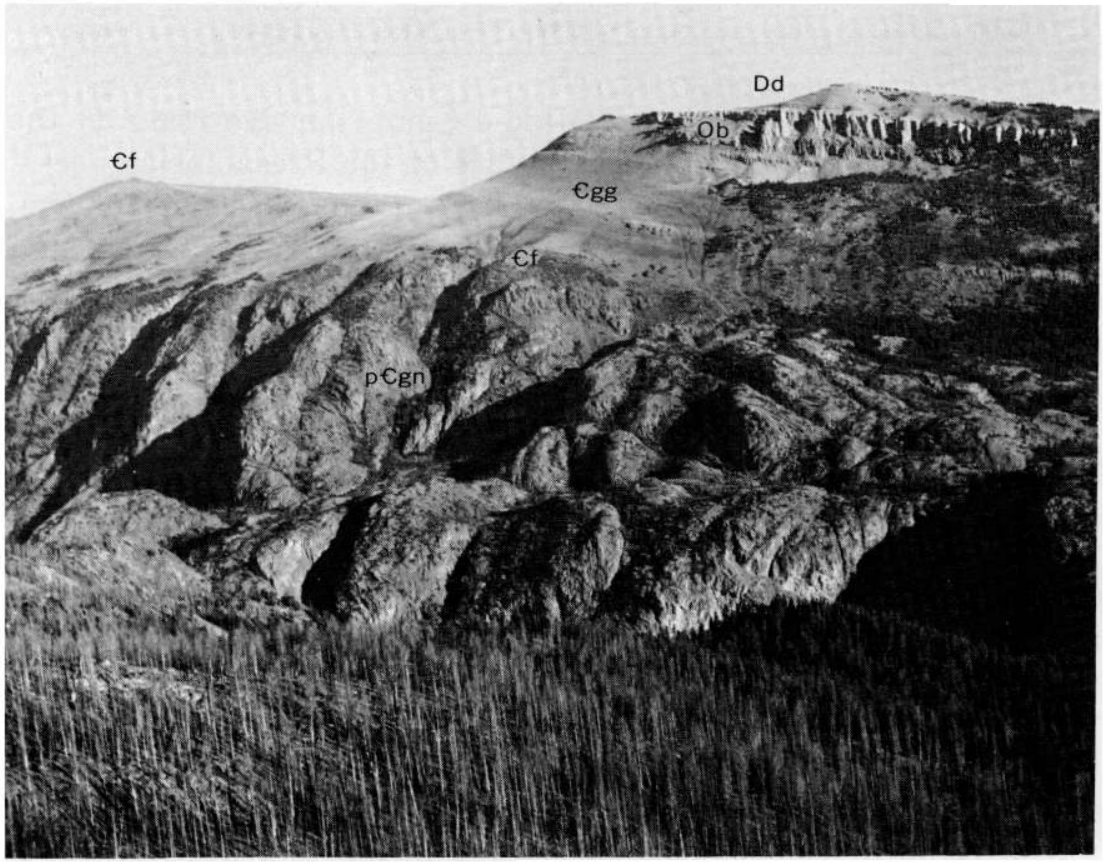

Figure 12.-The Paleozoic sedimentary sequence, which dips northeastward from the flank of the Wind River Range; northwesterly view across the canyon of Dinwoody Creek. Flathead Sandstone ( $€ f$ ) forms the hump on the skyline to the far left and underlies the Gros Ventre and Gallatin Formations ( $\mathrm{Ggg}$ ), which form the smooth slopes. Above is the cliffforming Bighorn Dolomite (Ob). Darby Formation (Dd) forms the skyline to the far right. Knobby rocks in the middle foreground are gneiss of Precambrian age $(p € g n)$. 
TABLE 1.-Measured thicknesses of Paleozoic sedimentary rocks in and near the Glacier Primitive Area

[Thicknesses reported by Keefer (1957) are largely from Warm Spring Creek and Little Warm Spring Creek areas; thicknesses reported by Gilliland $(1959)$ are largely from Jakeys Fork and Little Warm Spring Creek areas; thicknesses reported by Mooney (1951) are from Torrey Creek area; thicknesses reported by Murphy and Richmond (1965) are from near Bull Lake]

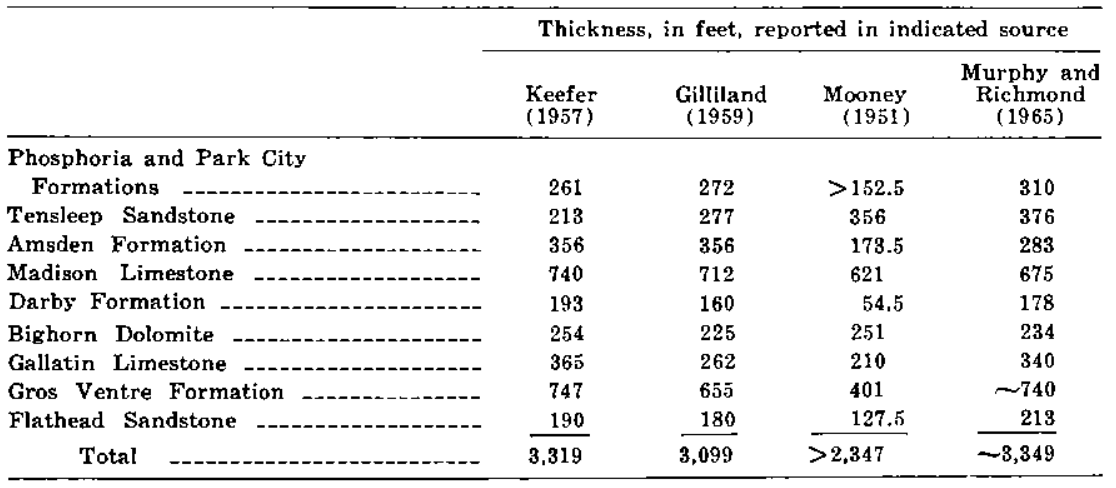

The Flathead Sandstone of Middle Cambrian age rests on the remarkably smooth peneplaned surface of the Precambrian rocks. The Flathead is about 150 feet thick and composed of reddishbrown to tan, coarse-grained, quartzose sandstone. Although harder and more resistant than the immediately overlying rocks, it fractures easily and commonly forms a layer of rubble which blankets the pre-Flathead erosion surface.

The Gros Ventre Formation, also of Middle Cambrian age, conformably overlies and intertongues with the Flathead Sandstone, suggesting that the lower part of the Gros Ventre is an offshore facies of the Flathead. The Gros Ventre is about 500 feet thick and is composed of easily weathered interbedded brownish- to greenish-gray glauconitic and micaceous shales and thin limestone beds. Most of the formation weathers to a smooth slope covered with grass, but a resistant thin-bedded limestone unit in the lower middle part of the formation intermittently forms bold spines and hummocks.

The Gallatin Limestone of Late Cambrian age is gradational into the underlying Gros Ventre. This fact, plus the extremely poor exposure of the contact zone, prompted mapping of the Gallatin and Gros Ventre as a single unit (pl. 1). The Gallatin consists of about 250 feet of gray and brownish-gray limestone, dolomitic limestone, shale, and shaly limestone. The lower part of the formation is generally easily eroded, and only sporadic limestone ledges are exposed; the upper part is more resistant but is 
generally overshadowed by the overlying, highly resistant Bighorn Dolomite.

The 250-foot-thick Bighorn Dolomite, of Middle and Late Ordovician age, is dominantly a brownish-gray, massive, resistant, cliff-forming unit that grades from limestone at the base to dolomite in the middle and top. It is probably the most persistent cliff former in the area. The central dolomitic limestone typically weathers to a rough pitted surface that is easily recognized.

The Darby Formation, of Devonian age, is less resistant than the enclosing rocks and commonly forms slopes between prominent cliffs or saddles in ridges. The top and base of the Darby seem to have been placed at different horizons by different geologists, resulting in reported thicknesses that range from a few feet to about 190 feet in and near the study area. In general, the Darby is a brown to buff, banded unit, containing interbedded thin layer's of dolomite, limestone, limy shale, and sandstone.

The Madison Limestone of Mississippian age, the thickest sedimentary unit in the area, is about 650 feet thick. It is dense, massively bedded, gray limestone and dolomitic limestone that is generally resistant to weathering and commonly stands as cliffs or bold outcrops along valley walls; it caps many of the highest hills and ridges. Not protected by resistant overlying beds, it generally has a more subdued outcrop expression than the Bighorn Dolomite.

The Amsden Formation, of Late Mississippian and Pennsylvanian age, reportedly ranges in thickness from about 175 to 350 feet. It is composed of a lower white to reddish-buff, crossbedded, medium-grained sandstone that locally forms ledges or caps small ridges and an upper sequence principally of interbedded ferruginous red and green-gray shale and dolomite beds that weather to a slope. In places the lower part of the shaly sequence consists of a few tens of feet of brick-red, hematitic claystone or shale that contains numerous lenses of oolitic iron oxides. The oolites are composed of goethite, hematite, and minor kaolinite and average a little less than one-fourth inch in diameter.

The Tensleep Sandstone, of Pennsylvanian age, is about 350 feet thick and is resistant, white to pale-buff, crossbedded, finegrained sandstone. It forms prominent cliffs in some places and commonly caps rounded ridges and knobs.

Lithologies indicative of both the Park City and Phosphoria Formations, of Permian age, intertongue along the east side of the Wind River Range and reach a combined thickness of about 275 feet near the study area. Within the Glacier Primitive Area, 
however, only the lower limestone beds, which are referred to the Park City Formation, are present. These are poorly exposed in most places except for some of the more massive, gray to darkgray, highly fossiliferous limestones. Some beds are a coquina of broken and complete brachiopod shells, crinoid stems, and bryozoa and coral fossils. Black shale, chert, and phosphorite facies, indicative of the Phosphoria Formation, were not observed.

\section{TERTIARY ROCKS}

The Wind River Range, along with most of the Rocky Mountain region, was uplifted in the Laramide orogeny at about the beginning of the Cenozoic Era. Erosion cut through the Mesozoic and Paleozoic sedimentary rocks, exposed the Precambrian crystalline core of the range, and sculptured a chain of high mountains drained by deep canyons. As the intermontane basins became filled with debris contributed by erosion and regional volcanic activity, the flanks of the mountains and the mouths of canyons were inundated by sediments. Quaternary erosion has stripped much of this cover from the mountain flanks and exhumed the early Tertiary canyons, but remnants still persist in parts of the study area.

The Wind River Formation of Eocene age is the only Tertiary formation recognized in the study area. Only small remnants of it persist in the Torrey Creek drainage; these rocks seem to be locally derived and their compositions vary accordingly. Just east of the primitive area, on the north wall of Torrey Creek canyon, easily eroded red to tan conglomeratic rocks contain many large decomposed fragments of Precambrian granite and gneiss in an arkosic matrix. North of this area, in the lower part of Whisky Creek canyon, remnants of red conglomeratic strata contain pebbles and cobbles of both Precambrian crystalline and Paleozoic sedimentary rocks.

The Tertiary rocks along the north margin of the study area contain fewer conglomeratic strata than those near Torrey Creek and consist largely of red and white to buff tuffaceous sandstones and siltstones. Farther west, near Geyser Creek and along the Union Pass road (Lake of the Woods Roads on pls. 1 and 2), much of the surface that is underlain by Tertiary strata is strewn with cobbles and pebbles of well-rounded quartzite. These are so resistant that they locally persist even on thin soil zones overlying Precambrian rocks and make reliable mapping difficult. According to Rohrer (1968; oral commun., 1968), these cobbles represent one of several coarse channel-fill deposits in the upper part of the Wind River Formation. 
Some of the rocks mapped as Wind River Formation in the northwest part of the study area form gentle, featureless slopes covered with low vegetation and sporadic glacial boulders, which are most abundant near knobs of Precambrian rocks that rise above the smooth slopes. Much of this terrane was arbitrarily mapped as Wind River Formation on the basis of its characteristic topography or the occurrence of rounded quartzite cobbles, derived from the Wind River, which are scattered about the surface. Although the Wind River is definitely present in this area, its thickness and distribution are much in doubt.

\section{QUATERNARY DEPOSITS}

Glacial Deposits

Glacial deposits were separated into only two units for mapping. The younger of these consists of the neoglacial morainal material deposited largely by present-day glaciers (fig. 13). This material consists of large blocks, typically a few feet across, of Precambrian crystalline rock having very little finer grained matrix material. Much of the finer material seemingly is being washed farther downstream as glacial outwash, but some of it is

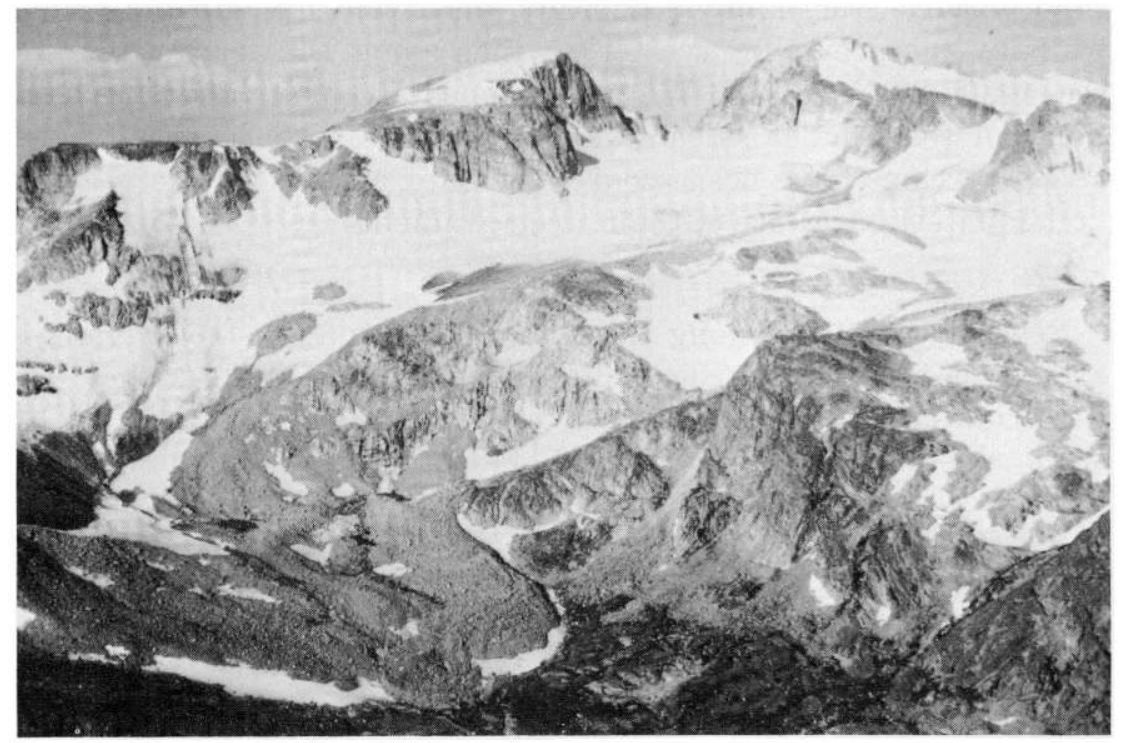

Figure 13.-Jackson Peak (on the left center) and the shoulder to the southeast (left) appear to be an uplifted segment of a peneplain; Fremont Peak is on the right. The terminal moraine in the central foreground has accumulated at the foot of one of the Bull Lake Glaciers. View southwestward toward Jackson Peak. 
packing downward between boulders as matrix material deep beneath the surface of the moraines. Several of the terminal moraines are separated from the toe of the associated glacier by a small lake, an indication that the glaciers have recently retreated.

The older glacial deposits are mostly bouldery till related to the Pinedale Glaciation of Pleistocene age. This is the last glaciation that extended far out onto the flanks of the range and deposited the moraine in lower Torrey Creek valley (pl. 1). The veneer of glacial material in many places in the higher mountain valleys, however, may have been left during retreat of the glaciers to their present restricted positions. This glacial material is actually more common along valley walls and foors than the map suggests because, in mapping, the veneer was ignored in areas of scattered bedrock exposures.

\section{Alluvium}

Alluvium has been deposited in many places where the stream gradients are fairly gentle (fig. 5). This material varies greatly in grain size and composition, ranging from peat and fine-grained detritus through fairly cleanly winnowed arkosic sand to cobbly and bouldery accumulations of reworked glacial material. Dune sand derived from alluvial deposits and swept up onto the valley walls by the prevailing westerly winds along Dinwoody Creek in sec. 10 , T. 38 N., R. $106 \mathrm{~W}$., was mapped as part of the alluvium. Some of the smaller stream valleys and extensive lengths of the larger streams have been scoured clean of all but the coarsest alluvial material because of their steep gradients.

\section{Landslide Debris}

Several landslides along the walls of the major stream valleys are composed of Paleozoic sedimentary rocks. Whereas the Precambrian crystalline rocks form many talus piles at the foot of steep slopes and high cliffs, the Paleozoic rocks tend in some places to break off and flow as larger landslides. Small slumped areas (not shown on pl. 1) covering an acre or less are fairly common on exposures of the Gros Ventre and Gallatin Formations, a fact suggesting that the larger landslides were probably also initiated in these unstable rocks.

\section{Felsenmeer}

Most unglaciated surfaces above timberline are covered by felsenmeer, a jumble of broken angular blocks as much as several feet across, composed of the immediately underlying rock and formed by frost action (fig. 14). Areas of soil are common on 


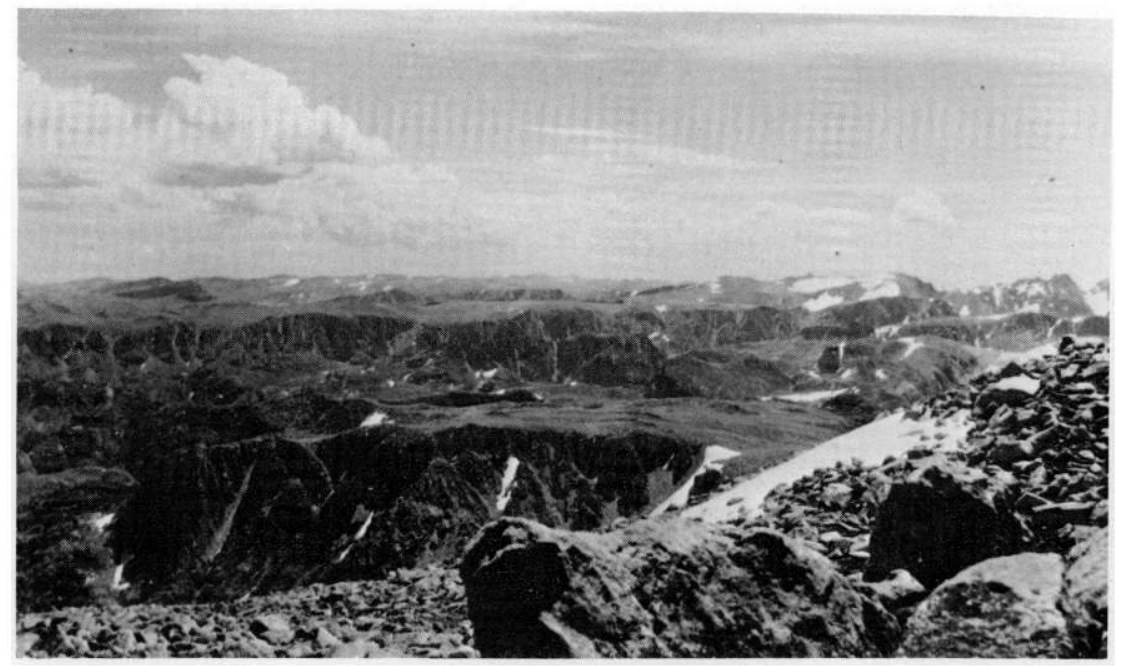

Figure 14.-Flat surfaces, now covered by felsenmeer, were beveled by peneplanation and are sharply incised by both stream- and glacier-carved canyons. View southeastward from the flank of Downs Peak.

these upland surfaces, and some of these support low-lying plants, but many areas are simply blanketed with disoriented blocks and slabs of rock. Although the frost and snow action contributes to slow creeping movement of this rock blanket, the moderately large blocks seem generally to be representative of the nearby bedrock and to have moved downslope only a few tens or a few hundreds of feet. The surfaces at Horse Ridge (fig. 15), Goat Flat, and Ram Flat consist mostly of felsenmeer.

\section{STRLCTLRE}

Major structural events that affected the rocks in the northern Wind River Range seem largely to have taken place during the Precambrian and Cenozoic Eras. Extensive faulting and shearing at relatively shallow depths during the Precambrian took place in the basement rocks after they had been subjected to deep-seated metamorphic and plutonic action. The Paleozoic and Mesozoic Eras were fairly uneventful tectonically and were characterized by accumulations of marine and continental sediments, now largely removed from the primitive area by erosion. The modern Wind River Range started to grow in Laramide time (Love, 1960; Berg, 1961) and is the result of extensive faulting and uplift accompanied by erosion that has continued intermittently until the present. 


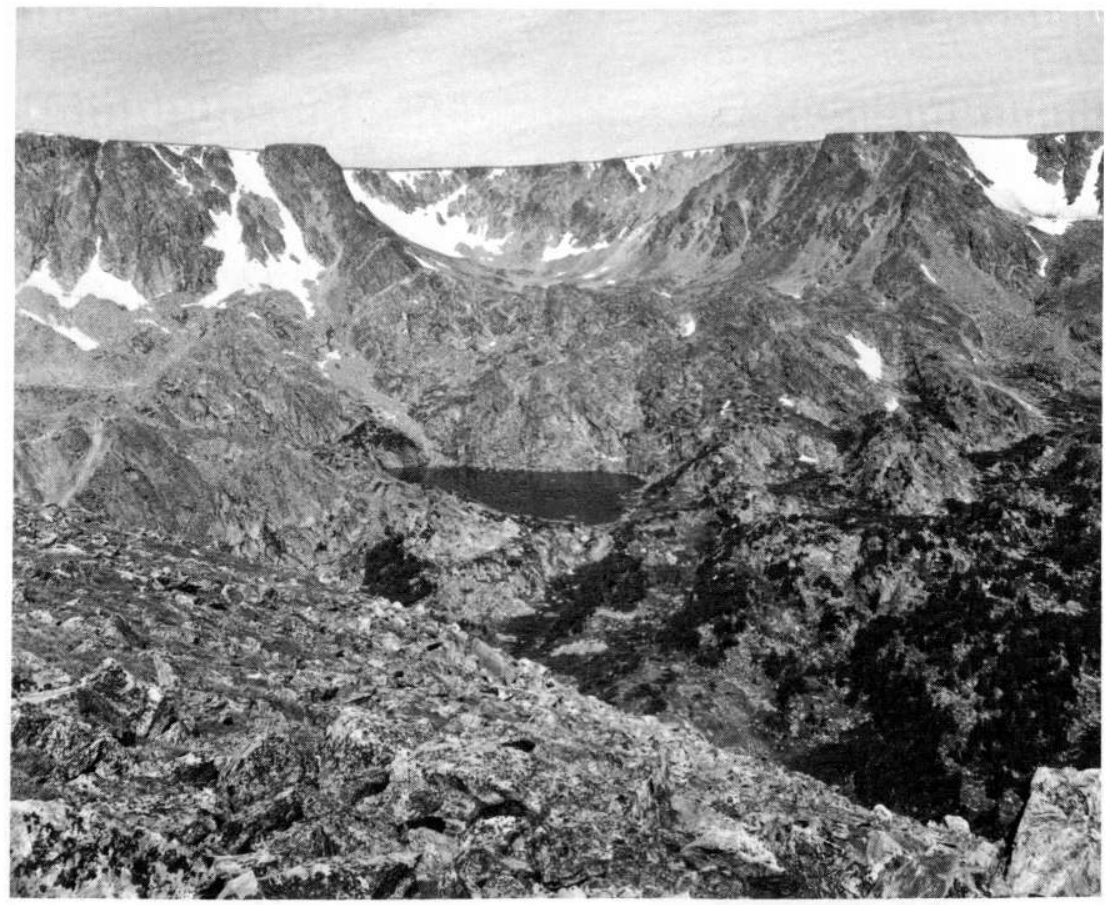

Figure 15.-The beveling effect of peneplanation; view looking northwestward at Horse Ridge across upper Dry Creek valley. Gneissic rocks that form the cliffs are laced with granitic and pegmatitic dikes. Felsenmeer covers surface in foreground.

The earliest clearly recorded Precambrian structures in the Wind River Range are of metamorphic origin. Premetamorphism structures, such as bedding, dikes, and faults, to which we have alluded in this report, were all but obliterated by metamorphism. Although foliation of the gneissic rocks is pronounced throughout the study area, no convincing evidence for isoclinal folding or other major metamorphic structures was distinguished during this investigation even though it is assumed that the rocks were folded prior to or during metamorphism. Most of the local changes in attitudes of foliation throughout the area can be attributed either to semiplastic deformation associated with emplacement of the large granitic bodies or to later faulting. The variety in foliation attitudes seems, therefore, to be related principally to local forces or faulting rather than regional forces related to deep-seated metamorphism.

The Mount Helen structural belt separating the two metamorphic terranes may represent a major fault zone that was 
active prior to the last stages of regional metamorphism proposed by Barrus (1968) for rocks and features along the same zone just east of the primitive area. If so, the occurrence of porphyritic granite in places along this zone indicates that the faulting preceded granite emplacement.

The Precambrian rocks have been highly faulted since metamorphism. In places these faults are evidenced by intensely fractured and altered zones, but many faults are largely concealed by surficial rubble, and few displacements can be detected. Alinement of topographic depressions such as lakes, stream valleys, and clefts in cliff walls indicates the presence of faults not otherwise exposed. The Paleozoic rocks, in contrast, show fewer faults, and most of those faults that are present are easily discerned by marked changes in dip or displacement of strata or both. Most of the faults recognized in the Precambrian rocks originated in Precambrian time, though a few were reactivated in Cenozoic time.

Wide, steeply dipping, northward-trending shear zones dominate the fault pattern in Precambrian rocks. One of the largest zones (fig. 16) enters the primitive area from the south and extends north-northwestward through the Alpine Lakes to a point where it disappears under moraines of the Bull Lake Glaciers. It may be traceable, as a lineament largely covered by glaciers, northward past the east face of Gannett Peak, and west of Downs Peak into Soapstone Basin and past Soapstone Lake. This projection assumes a slight offset, across the Jakeys Fork fault, into Paleozoic rocks along the north edge of the study area. Parts of this zone near the Alpine Lakes are well exposed and defined by crushed and altered rock over widths exceeding 1,000 feet. Other similar subparallel shear zones, farther north, pass through the Ross Lakes and through Simpson Lake. The Simpson Lake shear zone displaces the Goat Flat diabase dike horizontally over a distance of about a mile, whereas the Ross Lakes shear zone seems to terminate abruptly before reaching the dike-it may merge with a fault that trends southeastward across Bomber Lake, Goat Flat, and the Dinwoody Lakes.

A complex network of faults, possibly related in part to movements that created the large shear zones, cuts the Precambrian terrane throughout the area. Most of these faults do not seem to have produced any noticeable displacement on either the Goat Flat dike or the glomeroporphyritic diabase dike, a fact which suggests that the earliest fault movements predate the structures along which diabase was emplaced. Also, that only a few of the faults in Precambrian rocks can be traced into the Paleozoic se- 


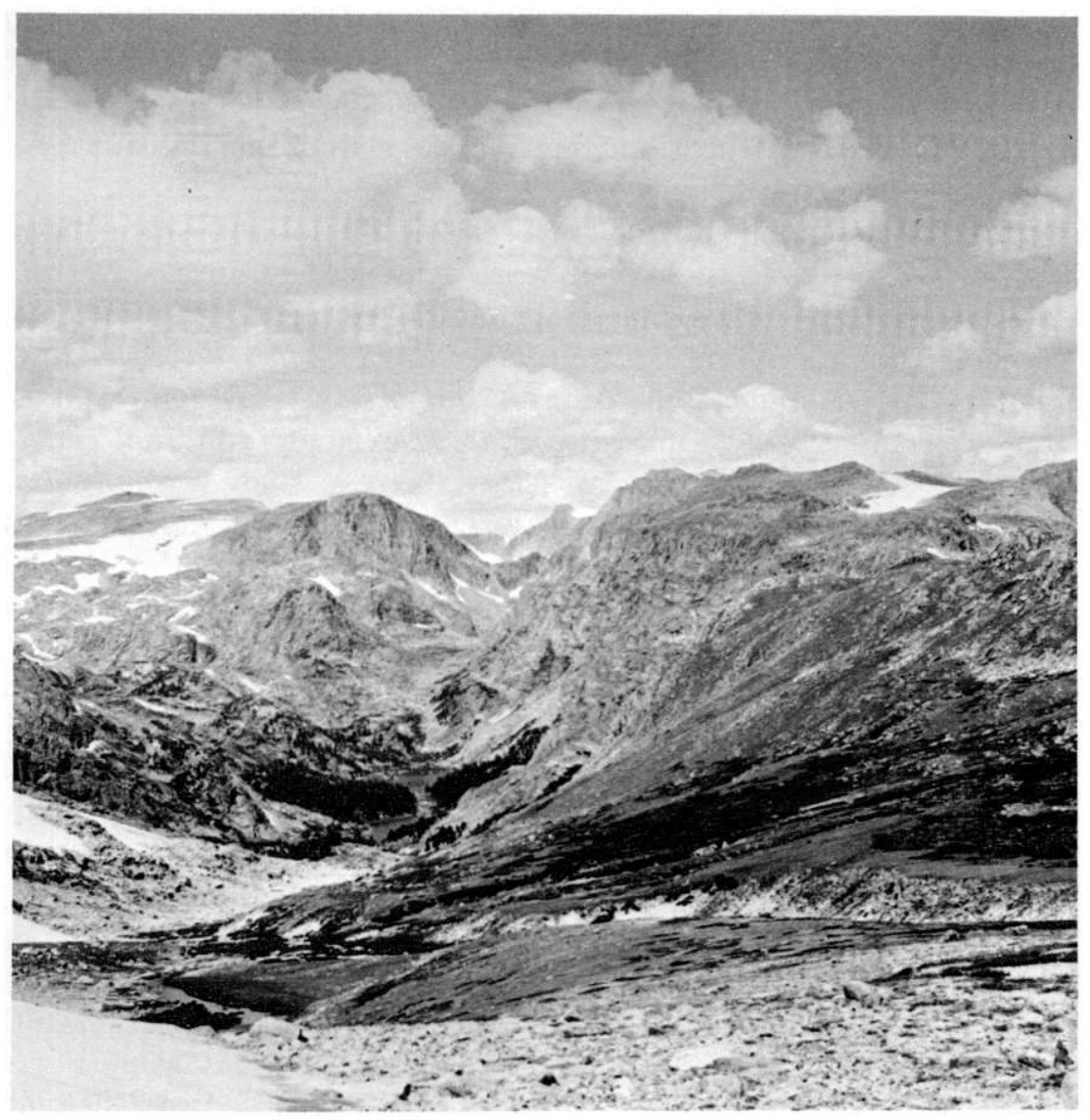

FigLre 16.-Topographic lineament formed along the Alpine Lakes shear zone; view northwestward from the southern part of the area.

quence indicates that they have largely been dormant since Precambrian time.

Most of the faulted rocks lack resistance to erosion and are concealed by surficial debris. Some northeastward-trending faults, however, contain a locally resistant, green-stained quartz-cemented breccia core (pl. 1) as much as 100 feet wide. Quartz fills and cements the fractured rocks and is itself weakly brecciated and cemented by films of green chlorite. These quartz-chlorite breccia zones are generally traceable for only short distances, as they commonly are covered by talus or morainal material. Scattered blocks of the quartz-chlorite breccia were seen in numerous localities where none could be seen in place. The significance of these northeastward-trending breccias was not determined, but 
their parallelism suggests close relation to a single structural event.

Faults that cut only Precambrian rocks may have been active in the Precambrian or the Tertiary or both. Is is assumed, however, that most of the present fault pattern was established in Precambrian time. Large thrust faults on the west flank of the Wind River Range were active during Laramide time and, presumably, some of the high-angle faults permitted adjustments in the upper plates of these thrusts even on the east side of the range. The large shear zones are characterized by pinching and swelling of broad zones of crushed and fractured rock and by silicified, chloritized, and epidotized wallrocks. In contrast, the Paleozoic rocks are abruptly upturned along narrow zones where they were dragged by high-angle normal faulting, and the associated alterations were silicification, argillization, and weak pyritization. Throw on the Ross Lakes fault where it cuts Paleozoic rocks north of Jakeys Fork is said to be about 470 feet (Gilliland, 1959), but this figure is probably minimal.

Eastward-trending faults which cut the Paleozoic rocks are typically downthrown on the north side, and north-trending faults are downthrown on the east. These movements are generally compatible with the relatively uplifted core of the Wind River Range.

Two eastward-trending normal faults-one follows parts of Jakeys Fork and the other crosses Little Warm Spring Creek about 3.5 miles to the north - may have formed entirely in Laramide time. Although both cut the Precambrian basement, there is no good evidence that they followed any preexisting structures. The Jakeys Fork fault cuts eastward through Paleozoic rocks, the north block being downthrown on the north side; the fault disappears under the glacial moraine near the lower end of Torrey Lake. It may be the same as the Twin Buttes fault east of the lake and the moraine (Gilliland, 1959), although the displacement there seems to be reversed.

The last significant tectonic event to affect the primitive area was probably a gentle arching of the Wind River Range sometime after formation of the mid-Tertiary peneplain. This may have been accompanied by greater upward movement in some of the fault blocks near the crest of the range. It is not clear whether the high peaks which form the spine of the Wind River Range were uplifted at this time or whether they are erosion remnants that resisted peneplanation. The north flank of Downs Peak and the southeast flank of Jackson Peak (fig. 13), at elevations of about 13,000 feet, both appear to be parts of the peneplain. 


\section{ALTERATION RELATED TO FAULTS}

For the most part, rocks are remarkably fresh and unaltered in and near the Glacier Primitive Area. With the exception of weathering, some of which is pre-Flathead, most alteration seems to be associated with faulting. Faults that cut Paleozoic rocks locally are silicified and weakly argillized and contain minor amounts of disseminated pyrite, which is oxidized to iron stain near the surface; few other effects of alteration can be noted. Precambrian rocks, in contrast, are locally epidotized and chloritized along faults and shear zones and, in addition, contain quartz stringers, magnetite, hematite, and sulfide minerals.

Silicification is probably the commonest type of alteration along faults throughout the area. The northeastward-trending faults previously mentioned commonly contain a thick filling of quartz-chlorite breccia. The Alpine Lakes shear zone and other faults in the southern part of the primitive area are commonly bordered by a granitic-appearing rock that is apparently a silicified, chloritized part of the surrounding migmatite. Silicification and cementation of brecciated granite were noted in the Jakeys Fork fault zone. Quartz veins and silicified streaks are present in the Ross Lakes shear zone where it is exposed between the lakes. Vugs and irregular cavities lined with attractive coatings of drusy quartz crystals are found in the middle Paleozoic carbonate rocks on the southeast side of Arrow Mountain near the Blue Hole Creek fault. The calcareous tufa deposits farther downstream at Blue Holes are doubtless a result of the carbonate leaching in these silicified parts of the fault zone.

Epidote is common in the wallrocks near fault zones, generally as narrow quartz-epidote veinlets. Float fragments of quartz and epidote as much as a foot across can be found along the shear zone at Hay Pass. Although epidote is perhaps most prevalent near faults, its almost ubiquitous presence either as fracture fillings or as disseminated grains in most of the felsic rock and in some of the mafic rocks suggests more than one origin. (See also Barrus, 1968.) Chlorite, as films and fracture fillings in quartzchlorite breccia zones and as chloritized mafic minerals in the wallrocks of fault and shear zones, is much more prevalent in the southern part of the area than in the north.

Talc and clear fibrous amphiboles, such as anthophyllite, are found locally in faults generally north of the latitude of Dinwoody Lakes. Soapstone Lake and Soapstone Basin presumably derived their names from talc-rich boulders found in the moraine south of the lake. The origin of the talc and amphiboles is not 
known, but the source may have been narrow sheared and altered ultramafic dikes that were intruded into some of the early Precambrian faults.

Most of the observed effects of alteration, therefore, seem to be Precambrian in age and there is no evidence of strong argillization, sericitization, or extensive mineralization by sulfur-rich solutions. In short, the types of intense alteration related to many of the metallic ore deposits of the Western United States are generally lacking in the primitive area.

\section{MINERAL RESOURCES}

\section{HISTORY AND PRODUCTION}

Intensive prospecting in the Wind River Range began in the mid-19th century with the discovery of gold in the Atlantic City district at the southeastern tip of the range. Developments at Atlantic City were disappointing, however, and activity soon subsided. Shortly after 1900, gold was discovered in the gravels of Warm Spring Creek a few miles northwest of the Glacier Primitive Area. This discovery resulted in many attempts at smallscale mining, most of which were frustrated by the fine, flaky nature of the gold.

Uranium was discovered about 100 miles to the southeast in the Gas Hills district of central Wyoming in 1954 and 1955. In the succeeding several years, prospectors with Geiger counters and scintillation meters investigated most rock outcrops in the State, including those of the Wind River Range. Many claims were located on "favorable formations" and on minor radiometric anomalies that amounted to only two or three times normal background. Improved conditions in the uranium market in the late 1960 's resulted in another surge of uranium prospecting and caused renewed interest in uranium claims in the vicinity.

Small amounts of uranium have been found in shear zones in Precambrian and brecciated lower Paleozoic rocks and at weak radiometric anomalies detected near the base of the Flathead Sandstone and in Tertiary sedimentary units. Taconite-type iron deposits were discovered many years ago in Precambrian rocks near Atlantic City at the south end of the range (Spencer, 1916; Bayley, 1963), but they were not mined until recently, when economic methods for treating such low-grade remote deposits were developed.

No mineral production has been recorded from the Glacier Primitive Area. Production from within or near the contiguous area to the northwest consists of 6 tons of uranium ore, several 
hundred tons of facing stone, and probably several thousand dollars' worth of placer gold.

\section{GEOCHEMICAL SAMPLING AND ANALYTICAL TECHNIQUES}

A geochemical sampling program by the Geological Survey team was conducted concurrently with geologic mapping in 1968 and 1969, and 1,076 samples were collected. A total of 483 rock samples were taken both of typical rocks and of the few exposed veins, iron-stained or altered rocks, and other rocks that differed in color, texture, or apparent composition from their surroundings.

Rock samples were collected both from outcrops and from float fragments but, with few exceptions, float fragments were collected only if it seemed likely that they had moved just a short distance. Each sample consisted of two hand specimens, one of which was submitted for analysis and the other retained for reference and petrographic study. All rock samples were analyzed by semiquantitative spectrographic methods. Where additional data were desired, samples were analyzed specifically for various constituents. Analyses have been divided into petrologic categories in tables 5-11 (p. F64-F109) to facilitate comparisons.

Stream-sediment samples and panned concentrates were collected (pl. 2) at intervals from each major stream and from most of the flowing or intermittent tributary drainages. Each of the 470 stream-sediment samples consisted of approximately 4 ounces of sand- or silt-sized alluvium collected by hand at a place determined partly by the availability of fine sediment. Extensive distances along some torrential streams were traversed without finding any clastic material smaller than cobble size; other places, however, contained abundant sand and silt. After collection the samples were dried and screened and the minus-80-mesh fraction was analyzed. At 123 sample sites, about 3-5 pounds of sand or gravel was panned and the heavy-mineral concentrate analyzed. All analytical work was done in laboratories of the Geological Survey.

Nearly all the samples were analyzed for selected elements by spectrographic methods in a mobile field laboratory operated by D. J. Grimes and R. T. Hopkins, Jr., assisted by S. G. Meyers in 1968 and by W. D. Crim in 1969. Most stream-sediment samples were chemically analyzed for CxHM (citrate-soluble heavy metals) in a mobile field laboratory by A. J. Toevs. Panned heavymineral concentrates were analyzed for gold by atomic-absorption methods in the Denver, Colo., laboratories by A. W. Wells, J. G. 
Frisken, and M. S. Rickard. A few samples were analyzed in Denver for platinum metals or for other elements by L. B. Breeden, Gordon Day, J. V. Desmond, W. H. Ficklin, J. M. Gardner, W. D. Goss, Joseph Haffty, R. L. Miller, L. B. Riley, T. A. Roemer, and Z. C. Stephenson.

It was assumed that the properties of sediments in any stream represent a function of the composition of the terrane from which the sediments were derived. The composition of the minus-80-mesh fraction of bulk stream sediment should, therefore, be a function of the gross composition of rocks upstream. The $\mathrm{CxHM}$ content of the same sample is largely a function of oxidized metals that have become dissolved in the stream waters and concentrated by absorption on surfaces of fine detrital grains such as clays and organic matter.

Since organic matter is known to be a particularly good absorbent of dissolved metals, the sediment samples (table 12) that were observed to contain an appreciable proportion of finegrained organic material were distinguished from the remainder of the samples for objective comparison. No statistically significant differences were found, however, between organic-rich and organic-poor samples. All analytical data derived from the sampling program were placed on computer tape to provide greater efficiency in retrieval and organization of the information found in the various tables of this report.

\section{RESULTS OF SAMPLING STREAM SEDIMENTS FOR BASE METALS}

Stream-sediment samples found to contain at least $70 \mathrm{ppm}$ (parts per million) copper, $5 \mathrm{ppm}$ molybdenum, $70 \mathrm{ppm}$ lead, or $200 \mathrm{ppm}$ zinc by semiquantitative spectrographic analysis, or 8 ppm CxHM were arbitrarily considered to be anomalous. By these arbitrary criteria many anomalous samples were found, but none of them seems to indicate the presence of an economically usable ore deposit.

An anomalous stream-sediment sample can generally be attributed to erosion and weathering of nearby mineralized rocks; and several test samples were collected near known veins and ironstained areas. Some sediment samples collected downstream from anomalous rock samples, however, showed no comparable anomaly and, in places, anomalous rock samples were collected a short distance downstream from an anomalous sediment sample but no mineralized rocks were noted upstream. Also, sediment samples and mineralized rocks sampled nearby are not invariably anomalous in the same elements, for reasons not readily apparent. Some anomalous samples have questionable validity because the anom- 
alies were not duplicated by resampling (table 2). This discrepancy was not explained but might be attributable to sampling error, analytical error, erratic distribution of the anomalous metal, differences in the chemistry of the stream water, or a complete exchange of the sediment at the sample site.

TABLE 2,-Some compositional differences in sediment-sample pairs collected from the same sample site at different times

[All values in parts per million. ....., not looked for; $N$, looked for but not detected; $L$, detected, but below determination limit. For complete analysis see tables 10 and 11]

\begin{tabular}{|c|c|c|c|c|c|}
\hline \multirow[b]{2}{*}{$\begin{array}{l}\text { Sample } \\
\text { No. }\end{array}$} & \multicolumn{4}{|c|}{ Semiquantitative spectrographic analyses } & \multirow[b]{2}{*}{$\begin{array}{c}\text { CxHM } \\
\text { analyses }\end{array}$} \\
\hline & Mo & $\mathrm{La}$ & $\mathrm{Pb}$ & $Y$ & \\
\hline $\begin{array}{l}234 \\
784\end{array}$ & $\stackrel{7}{\mathrm{~N}}$ & $\begin{array}{r}200 \\
70\end{array}$ & $\begin{array}{l}50 \\
15\end{array}$ & $\begin{array}{r}200 \\
70\end{array}$ & -- \\
\hline $\begin{array}{l}345 \\
781\end{array}$ & $\begin{array}{l}\mathbf{N} \\
\mathrm{N}\end{array}$ & $\begin{array}{r}100 \\
50\end{array}$ & $\begin{array}{r}100 \\
20\end{array}$ & $\begin{array}{l}30 \\
15\end{array}$ & $\begin{array}{l}1 \\
1\end{array}$ \\
\hline $\begin{array}{l}338 \\
952\end{array}$ & $\stackrel{\mathrm{I}}{\mathrm{N}}$ & $\begin{array}{r}70 \\
150\end{array}$ & $\begin{array}{l}30 \\
15\end{array}$ & $\begin{array}{r}30 \\
>200\end{array}$ & $\begin{array}{l}1 \\
3\end{array}$ \\
\hline $\begin{array}{l}284 \\
786\end{array}$ & $\stackrel{N}{N}$ & $\begin{array}{r}1,000 \\
100\end{array}$ & $\begin{array}{r}100 \\
10\end{array}$ & $\begin{array}{r}200 \\
50\end{array}$ & $=-$ \\
\hline $\begin{array}{l}633 \\
777\end{array}$ & $\stackrel{5}{\mathbf{5}}^{-}$ & $\begin{array}{l}150 \\
100\end{array}$ & $\begin{array}{l}20 \\
15\end{array}$ & $\begin{array}{r}30 \\
>200\end{array}$ & $\begin{array}{l}3 \\
1\end{array}$ \\
\hline
\end{tabular}

Sediment samples were subjected to CxHM analysis to detect anomalous amounts of oxidized base metals absorbed from stream waters by sediment particles. Several sediment samples having normal CxHM analytical results seem to contain anomalous amounts of lead or copper as determined by spectrographic analysis, a fact suggesting that the anomalous metals may be held in rock-forming minerals rather than in absorbed form (table 3). Whether such samples can form any favorable basis for further prospecting is not known.

TABLE 3.-Some stream-sediment samples that contain anomalous lead or copper according to semiquantitative spectrographic analyses but show normal CxHM analyses

[All values in parts per million]

\begin{tabular}{ccc}
$\begin{array}{c}\text { Sample } \\
\text { No. }\end{array}$ & $\begin{array}{c}\text { Anomalous spectrographic } \\
\text { analyses }\end{array}$ & $\begin{array}{c}\text { CxHM } \\
\text { analyses }\end{array}$ \\
\hline 210 & $70 \mathrm{~Pb}$ & 1 \\
264 & $100 \mathrm{~Pb}, 150 \mathrm{Cu}$ & 1 \\
$\kappa 45$ & $70 \mathrm{~Pb}$ & 1 \\
358 & $70 \mathrm{~Pb}$ & 1 \\
381 & $70 \mathrm{~Pb}$ & $\mathbf{3}$ \\
697 & $100 \mathrm{Cu}$ & 1 \\
740 & $70 \mathrm{~Pb}$ & 3 \\
744 & $70 \mathrm{~Pb}$ & 1 \\
745 & $70 \mathrm{~Pb}$ & 1 \\
757 & $70 \mathrm{~Pb}$ & 1 \\
772 & $70 \mathrm{~Pb}$ & 3 \\
793 & $70 \mathrm{~Pb}$ & 3 \\
1025 & $70 \mathrm{~Pb}$ & 3 \\
1034 & $100 \mathrm{~Pb}$ & \\
1036 & $150 \mathrm{~Pb}$ & \\
\hline
\end{tabular}


Sediment samples $317,737,962,1003$, and 1062 contained more than $10 \mathrm{ppm}$ CxHM and were also anomalous in copper or lead or both (determined by semiquantitative spectrographic analysis). No evidence of iron stain, strong alteration, or other indication of mineralization was found near any of these samples, other than for sample 1003 which was collected in a generally iron-stained zone seemingly related to nearby gossan-filled veins of narrow width and strike length (see vein samples 861 and 862, table 9).

Many of the stream-sediment samples contained what seem to be anomalous amounts of chromium and nickel, but these elements were not found to be anomalously abundant in any of the vein or breccia zones. Most probably the stream sediments acquired chromium and nickel from amphibolites and ultramafic bodies, which commonly contain more of these elements than intermediate and felsic rocks but which are still well below ore grade. The chromium and nickel were not traced to any particular amphibolite or ultramafic body, but amphibolites are fairly common in this region and shed debris to nearly all the streams north of the Mount Helen structural belt.

Stream-sediment samples containing anomalous amounts of base metals do not seem to show any marked clustering in any part of the study area. On a broad scale anomalous samples came largely from three areas:

1. A wide area extending southeastward from the headwaters of Warm Spring Creek through Native Lake. Several samples from this zone contain anomalous CxHM, copper, lead, molybdenum, or zinc. Several quartz-, pyrite-, and gossan-filled veins were noted in the country rocks which indicates widespread but weak mineralizing activity.

2. The headwaters of Dry Creek. Several samples showing lead or CxHM anomalies were collected in this area. Gneiss in the sampled area locally contains iron-stained zones, but little other evidence of alteration or veins was noted.

3. The headwaters of Bull Lake Creek and the Middle Fork of Bull Lake Creek. Many samples were anomalous in lead and CxHM. This area is in migmatite, which field mapping and sampling showed to be uniformly unmineralized.

The vague tendency for anomalous samples to be grouped in these three areas has little obvious relationship to what is known about the lithology or structure of the study area. The Goat Flat diabase dike, because of its similar trend, may have some relationship to the first area noted above. Also, more of the anomalous samples seem to lie within aeromagnetic lows than in highs. 
However, the significance of the anomalous samples is not clear and, even though they might be considered anomalous and significant in some regions known to contain minable ore deposits (Steven and others, 1969), there seems to be little likelihood that they are related to deposits in the study area that can be exploited economically.

\section{PRECIOUS METALS}

No gold deposits of economic interest were found during this study. The highest grade sample (729, table 11), containing 1.24 ppm gold, was a panned concentrate from Snowshoe Creek draining into Warm Spring Creek in the northwestern part of the study area. All other panned-concentrate samples contained less than $1 \mathrm{ppm}$ gold, and most contained less than $0.1 \mathrm{ppm}$. The samples which contained more than $0.01 \mathrm{ppm}$ gold were largely from drainages in or downstream from areas underlain by Tertiary sedimentary rocks in the northwestern part of the study area or from Precambrian crystalline terrane in the Dry Creek and Bull Lake Creek drainages. Several of the anomalous samples from drainages in Precambrian rocks were collected downstream from localities known to contain small weak sulfide-mineral veins. The highest grade lode sample (441, table 9) contained $0.3 \mathrm{ppm}$ gold and was from a sulfide-bearing vein in the vicinity of the Ink Wells. One part per million gold is about equal to $\$ 1.00$ per ton at a price of $\$ 35.00$ per ounce for gold. None of the samples indicates deposits that can be worked economically at present.

Schrader (1915) reported placer gold deposits being worked in the early 1900's along Warm Spring, Bull Lake, Dry, and Dinwoody Creeks. Each of these occurrences is well outside the study area in terrane now or once underlain by lower Tertiary sedimentary rocks-similar to rocks which are known to be weakly auriferous farther to the west (Antweiler and Love, 1967). The gold in the alluvium in Warm Spring Creek, as well as the gold in the Wind River Formation, is so extremely fine-grained that it is known as "flour" gold, and there is little tendency for it to concentrate naturally in placers. Although Ketner, Keefer, Fisher, Smith, and Raabe (1966) implied that the Dinwoody Creek placers derived their gold from Precambrian rocks in the Wind River Range, just as plausible an interpretation is that the lower reaches of streams draining the primitive area derived much of their gold from the Tertiary rocks.

Persistent local rumors were heard, during this study, of a gold prospect that had been operated by Chinese prospectors in the Klondike Lake area. Whether the prospect was a lode or a placer 
is unclear, but the present study does not indicate any gold deposits in that area. Schrader (1915) did not mention any gold deposits within the primitive area.

Silver was detected in a few samples from sulfide-bearing veins, but all samples were well below economic limits. Samples from the Ink Wells vein contained as much as $15 \mathrm{ppm}$ silver by semiquantitative spectrographic analysis but no more than 10 ppm silver by activation analyses. These were the richest samples collected.

Because platinum metals are commonly concentrated by magmatic processes in ultramafic igneous rocks, several samples (13, $21,34,459,460,507,524$, table 7 ) of the ultramafic rocks in the primitive area were analyzed specifically for platinum, palladium, and rhodium. None of the samples, however, contained enough of these metals to be reliably analyzed, and all indicate rocks too low in grade to evoke any economic interest.

\section{SULFIDE-MINERAL OCCURRENCES}

Most metallic-mineral deposits in the Western United States contain sulfide minerals which oxidize readily near the surface to leave reddish-brown iron-stained zones and gossan. Iron-stained rocks were therefore studied and sampled during this investigation because of the possibility that they might be surficial indications of metallic-mineral deposits at depth. In some places pyrite was found just beneath the oxidized surface. Several of the samples collected from iron-stained rocks or gossan and from rocks containing iron sulfides were found to contain anomalous amounts of base and precious metals, but none was of sufficient grade or quantity to suggest the presence of an economically exploitable deposit.

\section{Gossan- and Pyrite-Bearing Veins}

Although a few pyrite-bearing veins were found in the study area, most of them are narrow and of short strike length, are in weakly altered rock, and contain only small concentrations of base and precious metals. All the veins are partly oxidized at the surface; several consist solely of porous limonitic breccia and gouge where exposed, but they undoubtedly contain iron sulfide minerals at depth. Obviously, no strong mineralizing event has affected the area, and the diverse character and orientation of the several sulfide-bearing veins and zones suggest that they do not owe their origin to any single source.

The largest pyrite-bearing vein seen during this investigation trends northward across one of the Ink Wells Lakes (pl. 1) in 
sec. 11, T. 38 N., R. $106 \mathrm{~W}$. The mineralized vein zone contains disseminated pyrite and perhaps other sulfide minerals, is as much as 8 feet wide, and is traceable intermittently for nearly 1,000 feet. Grab samples (39 and 40, table 9) and chip-channel samples (441-444, table 9) all contain anomalous concentrations of silver, copper, lead, and zinc, but the amounts are well below economic limits. A sediment sample (375, table 10) from the outlet of the lake crossed by the vein contained only zinc in anomalous amounts.

Several large iron-stained areas are present in the gneiss along the north side of the North Fork of Bull Lake Creek. At least some of the iron stain is related to limonitic pyritic veins. In one of the largest of these areas, a lithologically complex area northwest of Little Milky Lake, the rocks are faintly to heavily stained. The gneisses there contain large amphibolite bodies, numerous pegmatite dikes, and one or more ultramafic lenses, all of which are somewhat affected by iron stain that seems to have emanated, at least in part, from a few narrow northwestward-trending gossan veins. Samples of the gossan (861 and 862, table 9) contained a little anomalous silver, copper, and lead; sediment samples from a small stream draining the area all contained anomalous amounts of copper.

The highest copper value detected during the sampling program-2,000 ppm-was from a specimen of ultramafic rock (sample 845, table 7) containing extremely fine grained sulfide minerals disseminated along a few hairline fractures. Most of this sample, as well as nearby rocks, was barren of sulfide minerals, and no economic importance is believed to be indicated by the sample results.

Another high copper value detected in vein material during the sampling program was from a small isolated fracture in a diabase dike. The fracture was filled with a quartz-epidote-pyrite veinlet that contained a few visible flecks of chrysocolla (sample 825 , table $9 ; 1,500 \mathrm{ppm}$ copper). A gossan-rich sample of float (sample 54, table $9 ; 1,000 \mathrm{ppm}$ copper) presumably was derived from a vein zone that crosses Goat Flat. Little, if any, economic signficance can be attached to either occurrence.

Biotite-schist lenses and boudins and biotite-rich fault zones in the study area are commonly iron stained, and some contain disseminated to massive pyrite a few inches below the weathered surfaces. Most of these are small, sporadic occurrences, but some seem to have considerable width and continuity. About a mile northeast of Klondike Lake, for example, is a 4- or 5-foot-wide 
biotite-quartz-pyrite vein more than 200 feet long that strikes $\mathrm{N}$. $70^{\circ} \mathrm{W}$. and dips $75^{\circ} \mathrm{NE}$. In places the vein contains as much as an estimated 25 percent pyrite. A sample (447, table 7 ) contained anomalous amounts of cobalt, copper, and molybdenum, and some similar veins elsewhere also contain small but anomalous quantities of lead and zinc. Unoxidized pyrite can be found just beneath the surface of some of these deposits, which indicates that oxidation and leaching have been negligible and, therefore, that the analyses of surficial samples probably are representative of the vein at greater depths.

\section{Disseminated Sulfide-Mineral Occurrences}

Disseminated grains of sulfide minerals are rare in the country rock but were noted in a few places (samples 75 and 1109 , table 6 ; 181 and 417 , table 9 ; and 476 and 838 , table 7 ). Of interest were two hand specimens that contained small crystals of molybdenite and which were collected in vastly different types of rock at widely separated localities. One of these, sample 75, apparently unaltered, was from leucocratic granite of the Middle Mountain batholith and contained $700 \mathrm{ppm}$ molybdenum. The other, sample 838 , contained a crystal of molybenite in a small, partly leached cavity in an ultramafic rock. The analyzed fragment of this sample contained $5 \mathrm{ppm}$ molybdenum. Sample 476, containing 200 ppm copper, was taken from a diabase dike which locally contains sparsely disseminated pyrite near a northward-trending fault that displaces the diabase.

Patches of weakly iron-stained rock were noted only in the gneiss, granite, and migmatite north of the Mount Helen structural belt. These patches range from a few tens of feet to a few hundred feet across, have no continuity or trend, and are seemingly unrelated to faults or veins. Although no sulfide minerals were seen in these zones, disseminated pyrite may be associated with the mafic minerals of the rock below the weathered surfaces. These zones seem to contain, other than iron, no anomalous concentrations of metals.

\section{MAGNETITE-HEMATITE VEINS}

Narrow fracture fillings of magnetite, hematite, and quartz are present in many places in and around the Middle Mountain batholith. Hematite, perhaps mixed with some magnetite, commonly forms a dense, fine-grained gray filling in which are scattered minute octahedrons of magnetite. Generally, no other metallic minerals are associated with these veinlets. Uranium, however, 
may be related to hematite-magnetite mineralization in parts of the breccia of the Little Warm Spring Creek deposit.

In a few places quartz veins contain small pods and stringers of specularite, but they appear to have no economic significance. Vertical veins of this type striking N. $10^{\circ} \mathrm{E}$. and as much as 18 inches wide occur near an old collapsed and abandoned cabin along a stream draining into Jakeys Fork in sec. 33, T. 41 N., R. $107 \mathrm{~W}$. No prospect pits were seen in the vicinity, and the veins appear not to contain exploitable material.

Samples taken by the Bureau of Mines team from an ironstained zone in the primitive area on the northwest side of Horse Ridge along the upper drainage of Dinwoody Creek (sec. 14, T. 38 N., R. 106 W.) contain disseminated magnetite. An exposure on the bank of Wildcat Creek (sec. 3, T. 41 N., R. 108 W.) outside the study area consists of sheared migmatite and gneiss that also contain magnetite (Harrer, 1966).

No Precambrian iron-formation was recognized in place in the study area, although Worl (1968) reported a geologically significant, but uneconomic, body of metamorphosed iron-formation (taconite) about 1.5 miles southwest of Downs Peak in the Bridger Wilderness. An angular float sample (92, table 8), found in glacial till and talus debris along the Ross Lakes fault zone between the lakes, may be a fragment of taconite. Spectrographic analysis showed it to be rich in iron but rather low in magnesium, chromium, and nickel. It consisted of a dark-gray, laminated, very fine grained granoblastic aggregate of magnetite, anthophyllite, grunerite, quartz, green biotite, and chlorite. This sample may have had a nearby source within the fault zone, but it might just as well have been transported for a considerable distance by glacial action. Regardless, it is unlikely that any significant bodies of iron-formation would have been missed during the geologic traversing. The aeromagnetic survey likewise indicated no unusual concentration of magnetite.

\section{CHROMIUM AND NICKEL}

Nearly all the samples from diabase dikes, amphibolite bodies, ultramafic rocks, and talc- or amphibolite-bearing fault zones contain greater amounts of both chromium and nickel than do samples from more felsic rocks. Ultramafic rocks in particular, however, are normally much richer in these elements (table 4) than are other rocks, and it is unlikely that any economic importance can be attached to the fact that some of the samples from the primitive area are a little richer than the worldwide average. In- 
TABLE 4.-Crustal abundance of some metallic elements compared with their abundance in rocks of the Glacier Primitive Area

[Fe, Mg, Ca, and Ti values in percent; all other values in parts per miltion]

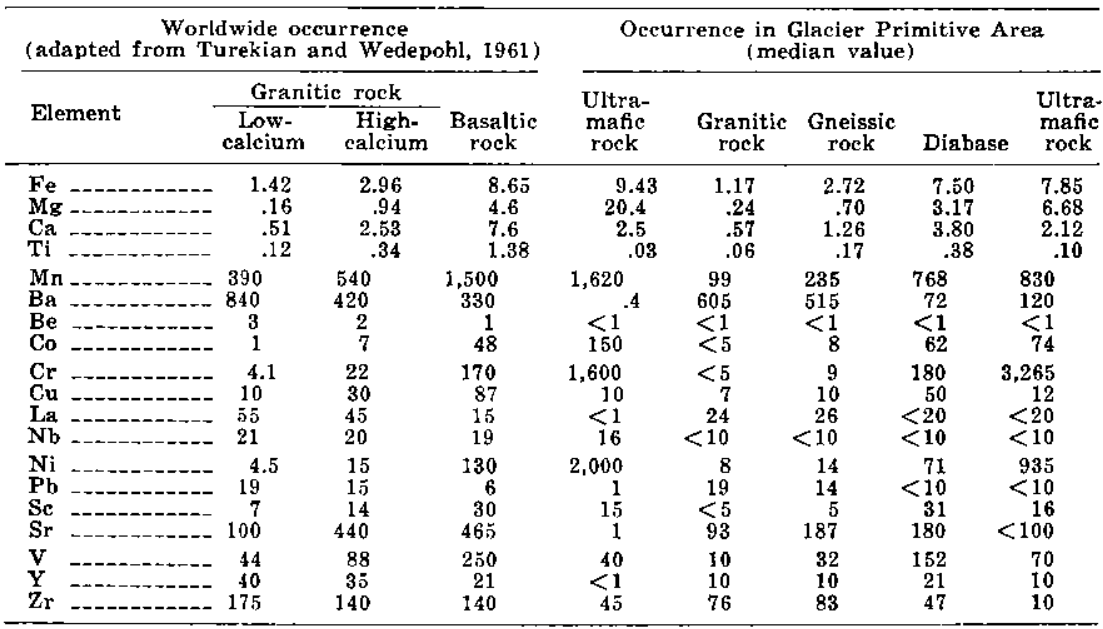

deed, the median value for nickel in ultramafic rocks from the primitive area is notably less than the worldwide average. No nickel minerals were recognized even in the higher grade samples, and the nickel in these is probably contained in rock-forming silicate minerals.

\section{NONMETALLIC MINERALS}

Our studies in the area revealed no deposits of nonmetallic minerals that would encourage further economic investigation. Phosphorite occurs in the Phosphoria Formation along the east flank of the Wind River Range (Blackwelder, 1911; Condit, 1924; Sheldon, 1963), but none of these occurrences is in the Permian strata investigated in this study (pl. 1). No phosphorite was found in the primitive area nor is any likely to be found, for the Permian rocks shown on plate 1 are mostly limestone beds of the Park City Formation rather than the facies of black shale, chert, and phosphorite typical of the Phosphoria Formation.

Talc, largely in the form of soft impure soapstone, is locally common as float boulders in felsenmeer and other rubble near faults in the north-central part of the study area. Presumably, the occurrences are narrow and well fractured, but talc weathers readily, providing meager surficial evidence of its presence.

Talc apparently occurs in several fault zones near Soapstone Lake and in Soapstone Basin; a few pieces of float were found on 
the edge of Goat Flat overlooking the Dinwoody Lakes and at one locality south of Crater Lake in sec. 16, T. 37 N., R. 105 W. At no place did the geologic setting or the abundance and purity of the float material seem adequate to indicate the presence of an economic deposit.

Green nodules as much as 8 inches long and 4 inches across occur in sec. 34, T. 38 N., R. 106 W., on Horse Ridge in a quartzbiotite vein which also contains some red garnet elsewhere along its strike. The nodules are extremely dense and tough and look much like jade but are almost pure sericite and have a little chlorite. Possibly they were sillimanite nodules altered by potassium metasomatism. Though pretty, the larger nodules are not common and are too soft to take a durable polish. No jade was recognized in the study area. Pegmatites within the study area are of simple granitic composition, and no significant concentrations of rare earths, beryllium, or mica were found in them.

\section{OIL AND GAS}

Records of the U.S. Bureau of Land Management indicate that one oil and gas lease was issued on land within the primitive area. This lease involves the $\mathrm{SE} 1 / 4$ sec. $3, \mathrm{NE} 1 / 4$ sec. 10 , and $\mathrm{E} 1 / 2$ sec. 14, T. 36 N., R. 106 W. (fig. 17). The lease was issued November 1,1964 , and terminated November 1, 1966. There is no record of drilling or production. This locality is underlain by Precambrian gneiss, and petroleum deposits are not likely to exist there. Although westward overthrusting on the west side of the Wind River Range has placed blocks of Paleozoic sedimentary rocks beneath plates of Precambrian rock (Baker, 1946), there is no evidence that these relations exist beneath the Precambrian rocks exposed on the east side of the range.

Within the study area there is no evidence of favorable structural or stratigraphic traps within the Paleozoic formations similar to those from which oil and gas are produced in the adjacent Wind River Basin. The area underlain by Paleozoic rocks is small, and all the formations are tilted and truncated, so that oil and gas, even if formerly present there, would probably have escaped at the surface or have been flushed by ground water.

\section{MINES AND PROSPECTS}

Fremont County records show that over a period of many years several hundred mining claims have been located in or near the study area but, according to Bureau of Land Management records, none of these has been patented. The present investigation 
R. $108 \mathrm{~W}$.

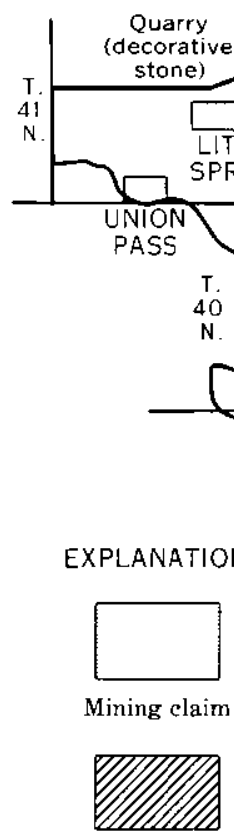

Mining or oil and gas lease
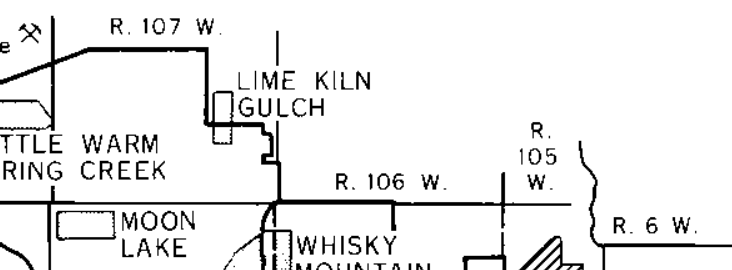

NOTE: ('laims and leases are shown approximately as described in county records but muy not correspond with location notices on the ground
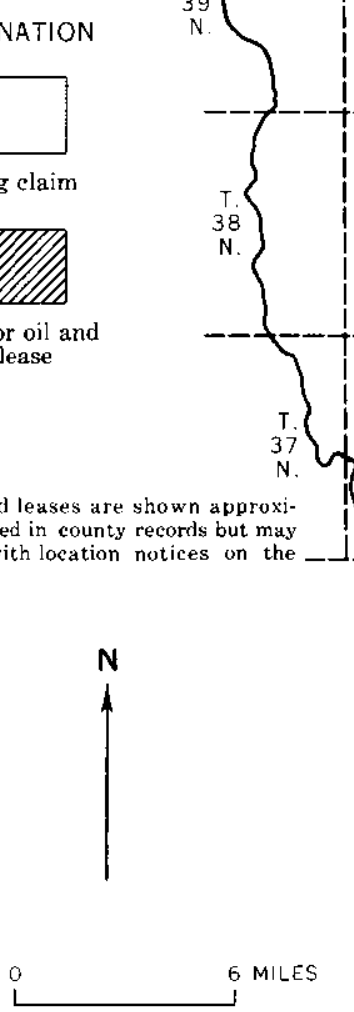

GLA C I E R

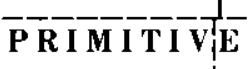


was concerned mainly with abandoned mine workings and with claims that have been active in recent years as revealed by location notices and affidavits of annual labor.

\section{Lime Kiln Gulch}

Lime Kiln Gu'ch, which lies between Jakeys Fork and Little Warm Spring Creek, has been the site of several periods of quarrying, prospecting, and claim staking. Remains of a lime kiln which was constructed to process limestone from a talus slope of the Madison Limestone for local use can still be seen. Appearance of the ruins indicates that production was small.

Here and elsewhere along the east flank of the range, the Madison Limestone is exposed in massive cliffs several hundred feet high. It has been a source of limestone at several localities in northern Wyoming. Because of the availability of limestone at more favorable locations and the lack of railroad transportation, outcrops of the Madison in the study area have little commercial value at present.

On the opposite (north) side of the gulch from the lime kiln, and only a few hundred feet outside the national forest boundary in sec. 23, T. 41 N., R. 107 W., an adit (pl. 1) has been driven along gossan and breccia in the Ross Lakes fault zone. The adit is now caved but appears to have trended N. $5^{\circ} \mathrm{W}$. for at least 75 feet (judged from the size of the dump) in Madison Limestone that strikes $\mathrm{N} .17^{\circ} \mathrm{W}$. and dips $84^{\circ} \mathrm{NE}$.

Waste material on the dump consists of iron-stained claystone and limestone and a few small limonite pockets which probably represent oxidized iron sulfide minerals; a few partly oxidized grains of pyrite were noted. Two samples of rock from the dump (494 and 827, table 9) contained anomalous amounts of either arsenic, barium, and or molybdenum. Another sample contained 0.001 ounce gold and 0.02 ounce silver per ton. A panned concentrate (766, table 11) of stream sediment from Lime Kiln Gulch a short distance below the fault contained anomalous amounts of barium, lead, and tin. The tin content may be attributable to oxidizing tin cans on the property. Samples $(452,453$, table 9) of iron-stained rock from the Ross Lakes shear zone within the study area and about a mile south of Lime Kiln Gulch also contained anomalous amounts of either arsenic, barium, and or molybdenum, but no metallic minerals were seen.

Chemically reactive rocks such as limestones are commonly favorable hosts for ore deposits, but the Paleozoic limestones are only weakly mineralized where cut by the Ross Lakes shear zone 
and are absent along those parts of the shear zone within the primitive area. The Ross Lakes shear zone, however, is a major structural feature and, although the geochemical anomalies found along it are all weak, it would be presumptuous on such scant data to rule out the zone completely as a target for further prospecting.

In 1956 a group of mining claims was located south and east of Lime Kiln Gulch (fig. 17) along a ridge that is now the site of a television relay station. Examination of this locality revealed no mineral occurrences of economic interest. Slightly anomalous radioactivity may have provided the impetus for location of the claims.

\section{Whisky Mountain}

In the mid-1950's, traces of uranium were found in the vicinity of Whisky Mountain (Theobald and King, 1954), and mining claims were staked over an area of about 2 square miles. The block of 40 claims lies partly within the primitive area (fig. 17). Affidavits of annual assessment work have been filed each year. The discovery point is on the north side of a knoll, in sec. 12, T. 40 N., R. $107 \mathrm{~W}$., and 1,000 feet north of the Ross Lakes jeep road. A partly caved 6-foot-deep shaft collared in the bottom of a 5foot-deep opencut is the principal development (pl. 1). The host rock is light-gray, brecciated, well-indurated, noncalcareous claystone interlayered with dolomite at the top of the Gallatin Limestone (or, possibly, in basal Bighorn Dolomite). To the north the same strata are thoroughly silicified to a chert breccia; dolomite occupies the same stratigraphic interval to the southeast.

The brecciated rock is iron stained and contains small rounded limonite-hematite concretions derived from oxidized iron sulfide minerals. Both white fluorite and purple fluorite occur sparingly in fractures. A few small barite concretions can be found, and carnotite was identified as a sparse fracture-surface coating.

Radioactivity in the opencut generally registers on the first scale of a Geiger counter (less than 0.2 milliroentgen per hour), although selected specimens gave second-scale readings $(0.2-2.0$ milliroentgens per hour). A sample (491, table 9) containing a few flecks of carnotite also contained anomalous arsenic, molybdenum, and vanadium and 0.016 percent uranium. Another selected sample (not shown in the tables) contained 0.06 percent $\mathrm{U}_{3} \mathrm{O}_{\mathrm{r}}$. No ore has been produced from this locality. Inasmuch as this deposit and the Lime Kiln Gulch deposit each contain anomalous amounts of arsenic, barium, and molybdenum, they both may 
be due to weak mineralization associated with the Ross Lakes shear zone.

\section{Little Warm Spring Creek}

A small amount of high-grade uranium ore was mined in 1956 from a shallow opencut (pl. 1) along a vein on the Dubois claims in Little Warm Spring Creek valley, sec. 24, T. 41 N., R. 108 W. Additional mining increased the total production from the original group of six claims to 6 tons of ore having an average grade of about 2.0 percent $\mathrm{U}_{3} \mathrm{O}_{x}$. Later, 44 more claims were staked (fig. 17 ), and exploration was continued in 1958, partly under terms of a Defense Minerals Exploration Administration (DMEA) contract. Four holes were diamond drilled, and the shear zone was penetrated at depths of about 100-200 feet, but no further ore discoveries were reported.

The deposit consists of a vertical breccia zone as much as 30 feet wide that trends $\mathrm{N} .19^{\circ} \mathrm{W}$. and cuts garnet-bearing biotite gneiss into which several narrow pegmatite bodies have been injected. The breccia is cemented by quartz, hematite, and magnetite; the wallrock is chloritized. Pitchblende (R. U. King and C. M. Harrer, written commun., 1957) associated with a little pyrite occurs in late fractures that cut the breccia zone.

Nine samples (478-483 and 496-498, table 9) were collected from the mine dump and from the wall of some small workings at the collar of a 20 -foot-deep shaft situated south of and about 40 feet higher than the opencut from which most of the ore was produced. Samples 497 and 498 were moderately radioactive, but only 497 contained uranium (about 0.2 percent) detectable by semiquantitative spectrographic methods; sample 497 contained a little anomalous cobalt, and nickel, and vanadium and $1,500 \mathrm{ppm}$ lead; and sample 480 contained $10 \mathrm{ppm}$ molybdenum.

A selected specimen (not shown in the tables) from the wall of the workings near the collar of the shaft and at about the same point as samples 497 and 498 contained 0.61 percent $\mathrm{U}_{3} \mathrm{O}_{8}$. This is ore-grade rock, and possibly a small amount of ore still remains in the deposit.

The shallow depth of the deposit and petrographic studies made during the period of active exploration suggested that the uranium deposits might not have a hydrothermal or hypogene origin (Harold Smithson, written commun., 1957). This conclusion prompts speculation that the uranium was derived by a supergene process from rocks such as the Wind River Formation which probably once overlay the area. If this is true, similar deposits 
might be present in the study area but would likely be small and could not be expected to extend to appreciable depth.

\section{Red Creek}

In 1952 a group of mining claims was located on a low-grade iron deposit in the Amsden Formation along the upper drainages of Red Creek and Little Red Creek, immediately inside the primitive area (Harrer, 1966, p. 44). Claims subsequently have been added, overstaked, and relocated, until the group now covers several square miles (fig. 17). Affidavits of annual labor have been filed on some of the claims each year.

Owners of the claims have also leased land underlain by the Amsden Formation east of the primitive area on the Wind River Indian Reservation. Development work on the claims and on leased land (fig. 17) consists of bulldozer trails and trenches, largely in sec. 19 , T. 40 N., R. 105 W.

A red-shale unit in the middle of the Amsden Formation above the basal member (the Darwin Sandstone Member) is rich in iron in many places along the northeast flank of the Wind River Range. Exposures of this shale in the vicinity of the claims are traceable for several miles by its conspicuous red-to-orange color which contrasts with the gray of most of the formation.

The red-shale unit is about 50 feet thick on the claims; the lowest 12 feet is richer in iron than the remainder. Much of the iron in the shale is concentrated in numerous lenses which are typically a few inches thick and several tens(?) of feet across and consist almost entirely of concentrically banded oolites composed of goethite, hematite, and kaolinite interspersed with and partly included in irregular masses of hematite.

A composite sample of iron-rich material taken during a previous Bureau of Mines investigation (V. T. Dow and W. E. Young, written commun., 1957) contained 13.3 percent iron, 71.5 percent insoluble material, and low percentages of phosphorus and sulfur. The sample having the highest grade was taken from a bed 6 feet thick; it contained 19.6 percent iron. Sampling during the present study confirmed the results of the previous investigation and showed that the oolitic lenses (samples 486, 487, 488, 490 , table 5) contain about 50 percent $\mathrm{Fe}_{2} \mathrm{O}_{3}$ (about 35 percent iron) in contrast to about 11 or 12 percent $\mathrm{Fe}_{2} \mathrm{O}_{3}$ (about 8 percent iron) in the dominant red-shale facies (sample 489). No direct market exists for material of this grade, and tests conducted indicate that there is no commerically feasible method of concentration. The most promising means of beneficiation-a reduction 
roast followed by magnetic separation-is currently too costly for treatment of such low-grade material. The iron-rich parts of the Amsden are not so well exposed elsewhere as they are at the opencuts in sec. 19, but there is no reason to believe that the iron content is substantially higher at other places along the strike of the Amsden within or near the primitive area.

\section{Moon Lake}

The Silver King group of 36 mining claims is located near Moon Lake (fig. 17) on terrane dominated by gneiss and migmatite cut by east-trending pegmatite dikes. Exploratory workings consist of a small opencut ( $\mathrm{pl} .1$ ) in outcrops along the edge of a marshy meadow on the northeast side of a hill about half a mile east of Moon Lake (sec. 6, T. 40 N., R. 107 W.).

This occurrence, though somewhat obscure geologically, seems to represent the intersection of a northeast-trending quartz-chlorite breccia vein and an amphibolite or ultramafic body enclosed in the gneiss. The amphibolite has been largely converted to biotite and chlorite; the irregular central part of the vein zone is filled with fine-grained hematite and magnetite and has a discontinuous core of vuggy crystalline quartz. Pyrite is sparingly disseminated in the dense, nearly black chloritic material. Only chromium or nickel is anomalously high in the samples taken (463-467, table 9 ) ; amphibolites or ultramafic rocks are typically enriched in both chromium and nickel.

The samples taken for this study do not bear out local reports of anomalous amounts of silver in the deposit. However, trace amounts of silver ( 0.02 ounce per ton) were found in a pyritebearing specimen (not reported in tables) from a pegmatite dike about 2 miles east of Moon Lake, near the east edge of the claims.

\section{Dinwoody Creek}

Two mining claims (fig. 17) have been located on Dinwoody Creek (secs. 16 and 21, T. 39 N., R. 105 W.) just inside the east boundary of the primitive area. This is in an area of gneissic rocks containing several dark-colored dikes (not mapped) that generally trend east. One dike contains a serpentinized zone that is weakly radioactive. The claims apparently were staked for uranium, but radiometric analysis of samples of the rock indicated the presence of only trace amounts of radioactive material.

Union Pass

In 1965 a group of 20 mining claims (fig. 17) was located on T. 41 N., R. 108 W., east of Union Pass. Exposures there consist of 
gneissic rocks cut by numerous pegmatite dikes. The dikes contain scattered magnetite, but no evidence of a commercial deposit was noted during this study. Current affidavits of annual labor have been filed on the claims.

\section{Decorative Stone}

A slabby red facies of the Flathead Sandstone is being selectively removed from a large talus pile near Geyser Creek in sec. 12, T. 41 N., R. 108 W., about a mile north of the study area. The talus is on national forest land and is being worked under terms of a materials disposal sale. The stone slabs are popular as facing for buildings, largely because of the interesting surficial patterns produced by lichen. Although similar slabby quartzite and sandstone are common in many parts of Wyoming, stone from this site is currently bringing fairly high prices in the building industry.

\section{Union Pass Uranium Claims}

A large, but unknown, number of claims (not shown on fig. 17) have been staked in the area north of Union Pass on ground underlain largely by the Wind River Formation. Most of these claims are west and northwest of the study area where the Wind River Formation is much thicker than it is in the study area. Parts of the Wind River Formation are known to contain anomalous amounts of gold (Antweiler and Love, 1967), and the formation is an important host rock for uranium in the Wind River and Shirley Basins farther to the east. The claims were reportedly staked primarily for uranium. Even though the results of exploration on these claims were not available when this report was being written, the combination of thinness and weathering in the Wind River Formation probably precludes any extensive uranium deposits in these rocks within the study area.

\section{Other Prospects}

Two very old prospect cuts were noted along the diabase dike on Goat Flat (sec. 25, T. 39 N., R. 107 W.), and a pair of shallow pits was found along the diabase dike (sec. 22, T. 41 N., R. 108 W.) near the northwest corner of the study area. Although the latter dike contains a little disseminated pyrite (sample 476 , table 7) near an apparent fault offset, other metallic minerals were not seen at the prospects on either dike.

\section{INTERPRETATIONS OF AEROMAGNETIC DATA}

In June and July 1969, the Geological Survey flew an aeromag- 
netic survey of the Glacier Primitive Area and adjacent areas. Thirty-nine east-west flight lines spaced about 1 mile apart were flown at a barometric elevation of 13,500 feet. The magnetic data were compiled relative to an arbitrary datum at a contour interval of 20 gammas. The magnetic contours are superimposed on the geology on plate 1. No laboratory measurements of rock magnetic properties were made.

Insofar as the geologic and geochemical data indicate, the surface rocks in the Glacier Primitive Area are apparently devoid of economic mineral deposits. The purpose of the aeromagnetic survey was to locate any magnetic anomalies that might indicate concealed or buried mineral deposits.

Magnetically, the primitive area can be divided into two parts that have different magnetic patterns: (1) The northeastern corner of the mapped area, where magnetic anomalies are almost all positive and are characterized by long wavelengths (5-10 miles) and gentle gradients, and (2) the remainder of the mapped area, where the wavelengths of the anomalies (both positive and negative) are similar and the gradients are steeper. The first area is underlain mainly by Paleozoic sedimentary rocks, and the second, by granite, migmatite, gneiss of granodioritic composition, and gneiss and migmatite intruded by granite and pegmatite dikes. Following are brief descriptions of the correlations between the magnetic data and the geology in the two areas.

In general, the area underlain by Paleozoic sedimentary rocks is typified by gentle magnetic gradients and only a few local anomalies, whereas the area underlain by Precambrian rocks generally has more anomalies having steeper gradients. If one assumes that the sedimentary rocks are essentially nonmagnetic and that all magnetic anomalies in this northeastern area are attributable to susceptibility contrasts in the underlying Precambrian basement rocks, then depth analyses based on magnetic gradients at several places (Vacquier and others, 1951) indicate the basement surface to be several thousand feet beneath the ground surface. The occurrence of predominantly positive anomalies over the Paleozoic sedimentary rocks suggests that the composition of the underlying basement rock is similar to the gneiss and migmatite exposed in the adjoining areas, rather than granite (which is characterized by relatively low magnetic intensities).

The exposed Precambian basement shown on the remainder of the magnetic map is differentiated into four lithologic units. The central part of this area is underlain by granite of the Middle 
Mountain batholith and is conspicuous because of its numerous closed, negative magnetic anomalies. The low magnetic intensity of this area undoubtedly reflects a lower magnetic susceptibility for the granite than for the surrounding basement rocks. Analysis of the magnetic gradients indicates that the negative anomalies represent ground-surface or near-ground-surface effects. North of Upper Ross Lake and at the southern end of the mapped area, near Hay Pass, the granite is not characterized by magnetic lows, a fact indicating geographic variability in its magnetic properties and a lack of contrast with the surrounding areas underlain by gneiss and migmatite.

Northwest and southeast of the Middle Mountain batholith are many positive and negative anomalies having fairly steep gradients that are associated with the exposed gneiss and migmatite. However, the gneiss and migmatite do not seem to have contrasting magnetic properties, for local anomalies appear to transect the contacts between them, and neither rock type is characterized consistently by low or high magnetic intensity. The anomalies northwest and southeast of the Middle Mountain batholith are believed to represent blocks of varying susceptibility within the basement, and the steep gradients indicate that the sources of most of them are at or near the ground surface. The single exception is the high having a peak value of 6,979 gammas near Indian Pass; the source for this anomaly is calculated to be at a depth of $1,500-2,000$ feet beneath the ground surface.

Of the three broad shear zones within the mapped area (pl. 1), two are associated with residual magnetic lows. The anomaly associated with the Alpine Lakes shear zone is interrupted by local anomalies, but if these anomalies were removed, a residual low of 20-60 gammas would remain. Similarly the southern part of the Simpson Lake shear zone, in the northern part of the mapped area, is marked by a residual low of about 20 gammas. These lows probably reflect altered rock in which ferromagnetic minerals have been destroyed; this alteration provides a susceptibility contrast with the adjacent, unaltered rock. The Ross Lakes shear zone has no magnetic expression. Evidently the magnetic contrast between sheared granite and unaltered granite is negligible.

A notable feature of the magnetic map is the total lack of magnetic expression of either the diabase dikes or the ultramafic bodies. Both of these rocks are more mafic than the enclosing rocks and are of types usually characterized by moderate to high magnetic susceptibilities. Apparently these dikes are too narrow in relation to their distance below the aircraft to have had any expression in the geophysical data. 
None of the magnetic anomalies in the Glacier Primitive Area and contiguous areas appears to be related to potential mineral deposits. With the above-noted exception, all the anomalies seem to originate at the surface of the Precambrian crystalline rocks, whether exposed or buried, and, insofar as the geologic and geochemical data indicate, these rocks are devoid of economic mineral deposits.

\section{CONCLUSIONS}

The absence of igneous intrusive rocks of Mesozoic or Tertiary age, the scarcity of hydrothermal alteration, and the apparent weakness of sulfide-mineralizing process within the study area indicate a geological environment that differs from that which characterizes most of the metal-mining districts of the Rocky Mountain region. Nothing was found during this study that indicates the existence of economically exploitable mineral deposits in the Glacier Primitive Area. A small tonnage of uranium ore was mined from the study area, northwest of the Glacier Primitive Area, but the deposit is small and is not thought to extend to an appreciable depth.

\section{REFERENCES CITED}

Antweiler, J. C., and Love, J. D., 1967, Gold-bearing sedimentary rocks in northwest Wyoming-A preliminary report: U.S. Geol. Survey Circ. $541,12 \mathrm{p}$.

Baker, C. L., 1912, Notes on the Cenozoic history of central Wyoming [abs.]: Geol. Soc. America Bull., v. 23, no. 1, p. 73-74.

1946, Geology of the northwestern Wind River Mountains, Wyoming: Geol. Soc. America Bull., v. 57, no. 6, p. 565-596 [repr., 1946, as Wyoming Geol. Survey Bull. 35].

Barrus, R. B., 1968, The bedrock geology of southeastern Alpine Lake quadrangle, Wind River Mountains, Wyoming: Pullman, Wash., Washington Univ., M.S. thesis, $46 \mathrm{p}$.

Bassett, W. A., and Giletti, B. J., 1963, Precambrian ages in the Wind River Mountains, Wyoming: Geol. Soc. America Bull., v. 74, no. 2, p. 209-212.

Bayley, R. W., 1963, A preliminary report on the Precambrian iron deposits near Atlantic City, Wyoming: U.S. Geol. Survey Bull. 1142-C, 23 p.

Berg, R. R., 1961, Laramide tectonics of the Wind River Mountains, in Symposium on Late Cretaceous rocks, Wyoming and adjacent areas, Wyoming Geol. Assoc. 16th Ann. Field Conf., 1961: Casper, Wyo., Petroleum Inf. (sales agent), p. 70-80.

Blackwelder, Eliot, 1911, A reconnaissance of the phosphate deposits in western Wyoming: U.S. Geol. Survey Bull. 470-H, p. 452-481.

- 1915, Post-Cretaceous history of the mountains of central western Wyoming: Jour. Geology, v. 23 , pt. 1 , no. 2, p. $97-117$; pt. 2, no. 3, p. $193-217$; pt. 3 , no. 4 , p. $307-340$. 
Branson, E. B., and Branson, C. C., 1941, Geology of Wind River Mountains, Wyoming: Am. Assoc. Petroleum Geologists Bull., v. 25, no. 1, p. 120-151.

Condie, K. C., Leech, A. P., and Baadsgaard, H., 1969, Potassium-argon ages of Precambrian mafic dikes in Wyoming: Geol. Soc. America Bull., v. 80 , no. 5, p. 899-905.

Condit, D. D., 1924, Phosphate deposits in the Wind River Mountains, near Lander, Wyoming: U.S. Geol. Survey Bull. 764, 39 p.

Gilliland, J. D., 1959, Geology of the Whisky Mountain area, Fremont County, Wyoming: Laramie, Wyo., Wyoming Univ., Unpub. M.S. thesis.

Harrer, C. M., 1966, Wyoming iron-ore deposits-Description, beneficiation processes, and economics: U.S. Bur. Mines Inf. Circ. 8315, 114 p.

Keefer, W. R., 1957, Geology of the Du Noir area, Fremont County, Wyoming: U.S. Geol. Survey Prof. Paper 294-E, p. 155-221.

Ketner, K. B., Keefer, W. R., Fisher, E. S., Smith, D. L., and Raabe, R. G., 1966, Mineral resources of the Stratified Primitive Area, Wyoming: U.S. Geol. Survey Bull. 1230-E, 56 p.

Love, J. D., 1960, Cenozoic sedimentation and crustal movement in Wyoming: Am. Jour. Sci., v. 258-A (Bradley volume), p. 204-214.

Mooney, A. R., 1951, Geology of the Torrey Creek area, Fremont County, Wyoming: Ames, Iowa, Iowa State Univ., unpub. M.S. thesis.

Murphy, J. F., and Richmond, G. M., 1965, Geologic map of the Bull Lake West quadrangle, Fremont County, Wyoming: U.S. Geol. Survey Geol. Quad. Map GQ-432.

Oftedahl, Christoffer, 1953, Petrologic reconnaissance in the pre-Cambrian of the western part of the Wind River Mountains, Wyoming: Norsk Geol. Tidsskr., v. 32, no. 1, p. 1-17.

Perry, Kenneth, Jr., 1965, High-grade regional metamorphism of Precambrian gneisses and associated rocks, Paradise Basin quadrangle, Wind River Mountains, Wyoming: New Haven, Conn., Yale Univ., unpub. Ph. D. dissert.

Richmond, G. M., 1945, Geology and oil possibilities at the northwest end of the Wind River Mountains, Sublette County, Wyoming: U.S. Geol. Survey Oil and Gas Inv. Map OM-31.

Richmond, G. M., and Murphy, J. F., 1965, Geologic map of the Bull Lake East quadrangle, Fremont County, Wyoming: U.S. Geol, Survey Geol. Quad. Map GQ-431.

Rohrer, W. L., 1968, Geologic map of the Fish Lake quadrangle, Fremont County, Wyoming: U.S. Geol. Survey Geol. Quad. Map GQ-724.

St. John, O. H., 1883, Report on the geology of the Wind River district: U.S. Geol. and Geog. Survey Terr. (Hayden) 12th Ann. Rept., pt. 1, p. 173-269.

Schrader, F. C., 1915, Gold placers on Wind and Bighorn Rivers, Wyoming: U.S. Geol. Survey Bull. 580-G, p. 127-145.

Sheldon, R. P., 1963, Physical stratigraphy and mineral resources of Permian rocks in western Wyoming: U.S. Geol. Survey Prof. Paper 313-B, p. 49-273.

Spencer, A. C., 1916, The Atlantic gold district and the North Laramie Mountains, Fremont, Converse, and Albany Counties, Wyoming: U.S. Geol. Survey Bull. 626, 85 p. 
Steven, T. A., Schmitt, L. J., Jr., Sheridan, M. J., and Williams, F. E., 1969, Mineral resources of the San Juan primitive area, Colorado: U.S. Geol. Survey Bull. 1261-F, $187 \mathrm{p}$.

Theobald, P. K., Jr., and King, R. U., 1954, Colorado-Wyoming district, in Geologic investigations of radioactive deposits, semiannual progress report-June 1 to November 30, 1954: U.S. Geol. Survey TEI-490, p. 223-227, issued by U.S. Atomic Energy Comm. Tech. Inf. Service, Oak Ridge, Tenn.

Turekian, K. K., and Wedepohl, K. H., 1961, Distribution of the elements in some major units of the earth's crust: Geol. Soc. America Bull., v. 72, no. 2, p. 175-191.

Vacquier, Victor, Steenland, N. C., Henderson, R. G., and Zietz, Isidore, 1951, Interpretation of aeromagnetic maps: Geol. Soc. America Mem. 47, $151 \mathrm{p}$.

Westgate, L. G., and Branson, E. B., 1913, The later Cenozoic history of the Wind River Mountains, Wyoming: Jour. Geology, v. 21, no. 2, p. 142-159.

Worl, R. C., 1968, Taconite and migmatite in the northern Wind River Mountains, Fremont, Sublette, and Teton Counties, Wyoming: Laramie, Wyo., Wyoming Univ., unpub. Ph. D. dissert.

1969, Migmatites of the Three Waters area, northern Wind River Mountains, Wyoming, in Abstracts for 1968: Geol. Soc. America Spec. Paper 121, p, 647-648. 


\section{TABLES 5-11}

Semiquantitative spectrographic analyses were made by D. J. Grimes and R. T. Hopkins, Jr., assisted by S. G. Meyers in 1968 and by W. D. Crim in 1969 .

Spectrographic analyses are reported to the nearest number in the series $1,0.7,0.5,0.3,0.2,0.15,0.1$, and so forth, which represent approximate midpoints of group data on a geometric scale. The assigned group for semiquantitative results will include the quantitative value about 30 percent of the time.

Numbers in parentheses indicate lower limits of determination, in parts per million. L, element was detected but was below the determination limit; N, element was looked for but not detected; -.., element was not looked for.

The elements $\mathrm{Ag}(0.5), \mathrm{As}(200), \mathrm{Au}(10), \mathrm{Bi}(10), \mathrm{Cd}(20), \mathrm{Mo}(5), \mathrm{Sb}(100)$, Sn (10), W(50), and $\mathrm{Zn}(200)$ were looked for. In tables 5-8 and 11, none was detected, except as indicated in footnotes. In table 9, only $\mathrm{Ag}, \mathrm{As}, \mathrm{Mo}$, and $\mathrm{Z}_{\mathrm{n}}$ were detected, except as noted. In table 10, only Mo was detected, except as noted.

Location: samples are located by section, township, and range. 
TABLE S.-Analyses of sedimentary rock samples

[Fe, $\mathrm{O}$, analyses, J. M. Gardner. Abbreviations used: bx, brecciated; cg $t$, conglomerate;

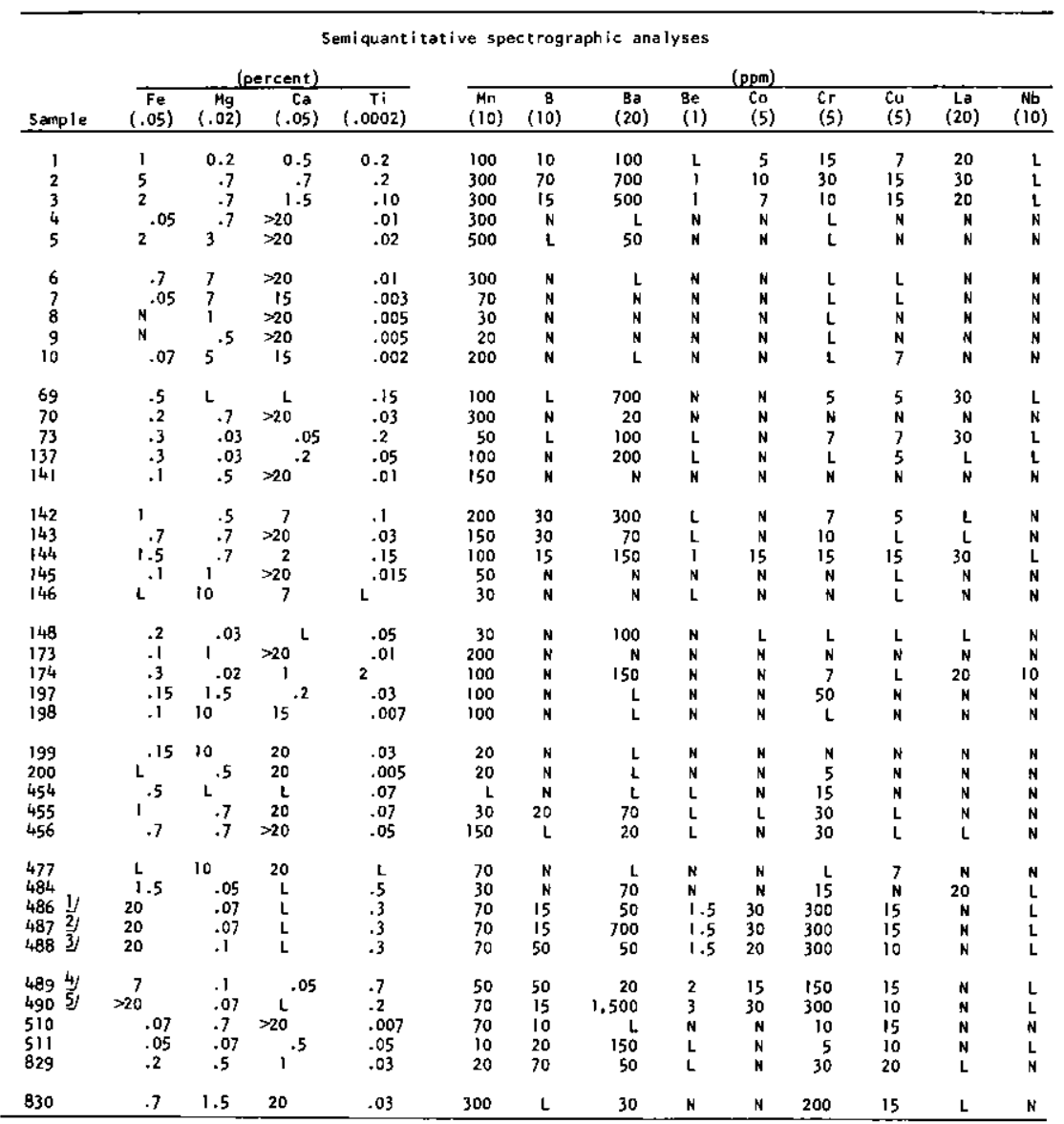

y Contains 46.5 percent $\mathrm{Fe}_{2} \mathrm{O}_{3}$; Mo detected but below determination 1 imit.

2) Contains 51.5 percent $\mathrm{Fe}_{2} \mathrm{O}_{3}$ and $10 \mathrm{ppm}$ Mo.

3) Contains 45.5 percent $\mathrm{Fe}_{2} \mathrm{O}_{3}$ and 7 ppm Mo. 
from the Glacier Primisive Area, Fremont County

dolo, dolomite; Fe st, iron stained; Ims, limestone; qtzt, quartzite; ss, sandstone; sh, shale]

\begin{tabular}{|c|c|c|c|c|c|c|c|c|c|}
\hline \multirow[b]{2}{*}{ Sample } & \multicolumn{8}{|c|}{ Semiquantitative spectrographic analyses--Continued } & \multirow[b]{2}{*}{$\begin{array}{l}\text { Format ions } 6 \text { f } \\
\text { and } 1 \text { ithologies }\end{array}$} \\
\hline & $\begin{array}{l}\mathrm{Ni} \\
(5)\end{array}$ & $\begin{array}{c}\mathrm{Pb} \\
(10)\end{array}$ & $\begin{array}{l}\text { Sc } \\
(5) \\
\end{array}$ & $\begin{array}{c}5 r \\
(100)\end{array}$ & $\begin{array}{c}V \\
(10)\end{array}$ & $\begin{array}{c}Y \\
(10)\end{array}$ & $\begin{array}{l}\mathrm{Zr} \\
(10)\end{array}$ & $\begin{array}{l}\text { Location } \\
\text { Sec-Twp-Rge }\end{array}$ & \\
\hline $\begin{array}{l}1 \\
2 \\
3 \\
4 \\
5\end{array}$ & $\begin{array}{r}3 \\
20 \\
5 \\
N \\
L\end{array}$ & $\begin{array}{c}N \\
10 \\
10 \\
N \\
N\end{array}$ & $\begin{array}{r}\mathrm{L} \\
10 \\
7 \\
\mathrm{~N} \\
\mathrm{~N}\end{array}$ & $\begin{array}{r}L \\
L \\
L \\
300 \\
200\end{array}$ & $\begin{array}{r}15 \\
30 \\
15 \\
L \\
L\end{array}$ & $\begin{array}{r}L \\
30 \\
20 \\
N \\
15\end{array}$ & $\begin{array}{r}200 \\
200 \\
150 \\
N \\
30\end{array}$ & $\begin{array}{l}21-40-106 \\
21-40-106 \\
21-40-106 \\
16-40-106 \\
16-40-106\end{array}$ & $\begin{array}{c}\text { Flathead qtzt. } \\
\text { Gros Ventre sh. } \\
\text { Gros Vent re ss. } \\
\text { Gallat in Ims. } \\
\text { Do. }\end{array}$ \\
\hline $\begin{array}{r}6 \\
7 \\
8 \\
9 \\
10\end{array}$ & $\begin{array}{l}\mathrm{N} \\
\mathrm{N} \\
\mathrm{N} \\
\mathrm{N} \\
2\end{array}$ & $\begin{array}{l}\mathrm{N} \\
\mathrm{N} \\
\mathrm{N} \\
\mathrm{N} \\
\mathrm{N}\end{array}$ & $\begin{array}{l}\mathrm{N} \\
\mathrm{N} \\
\mathrm{N} \\
\mathrm{N} \\
\mathrm{N}\end{array}$ & $\begin{array}{r}150 \\
N \\
150 \\
150 \\
N\end{array}$ & $\begin{array}{l}\mathrm{L} \\
\mathrm{L} \\
\mathrm{L} \\
\mathrm{L} \\
\mathrm{L}\end{array}$ & $\begin{array}{l}\mathrm{L} \\
\mathrm{N} \\
\mathrm{N} \\
\mathrm{N} \\
\mathrm{N}\end{array}$ & $\begin{array}{l}\mathrm{N} \\
\mathrm{N} \\
\mathrm{N} \\
\mathrm{N} \\
\mathrm{N}\end{array}$ & $\begin{array}{l}16-40-106 \\
16-40-106 \\
27-40-106 \\
27-40-106 \\
27-40-106\end{array}$ & $\begin{array}{l}\text { Bighorn Ims. } \\
\text { Bighorn dolo. } \\
\text { Madison dolo. } \\
\text { Madison Ims. } \\
\text { Darby dolo-lms. }\end{array}$ \\
\hline $\begin{array}{r}69 \\
70 \\
73 \\
137 \\
141\end{array}$ & $\begin{array}{l}2 \\
N \\
L \\
5 \\
N\end{array}$ & $\begin{array}{c}10 \\
N \\
N \\
N \\
N\end{array}$ & $\begin{array}{l}\mathrm{L} \\
\mathrm{N} \\
\mathrm{L} \\
\mathrm{N} \\
\mathrm{N}\end{array}$ & $\begin{array}{r}100 \\
500 \\
N \\
N \\
700\end{array}$ & $\begin{array}{r}10 \\
10 \\
15 \\
15 \\
L\end{array}$ & $\begin{array}{r}10 \\
\mathrm{~L} \\
10 \\
\mathrm{~N} \\
\mathrm{~N}\end{array}$ & $\begin{array}{r}200 \\
20 \\
300 \\
100 \\
L\end{array}$ & $\begin{array}{r}9-38-105 \\
33-39-105 \\
14-39-106 \\
12-38-106 \\
10-39-106\end{array}$ & $\begin{array}{l}\text { Flathead ss. } \\
\text { Gros Ventre } 1 \mathrm{~ms} . \\
\text { Flathead ss. } \\
\text { Flothead qtzt. } \\
\text { Gros Ventre Ims. }\end{array}$ \\
\hline $\begin{array}{l}142 \\
143 \\
144 \\
145 \\
146\end{array}$ & $\begin{array}{r}5 \\
3 \\
35 \\
N \\
N\end{array}$ & $\begin{array}{r}10 \\
10 \\
20 \\
\mathrm{~L} \\
\mathrm{~N}\end{array}$ & $\begin{array}{l}5 \\
5 \\
7 \\
N \\
N\end{array}$ & $\begin{array}{r}\mathrm{L} \\
500 \\
\mathrm{~N} \\
300 \\
\mathrm{~N}\end{array}$ & $\begin{array}{r}10 \\
10 \\
30 \\
L \\
L\end{array}$ & $\begin{array}{r}20 \\
L \\
L \\
N \\
N\end{array}$ & $\begin{array}{r}150 \\
30 \\
100 \\
N \\
N\end{array}$ & $\begin{array}{r}11-39-106 \\
2-39-106 \\
2-39-106 \\
2-39-106 \\
2-39-106\end{array}$ & $\begin{array}{l}\text { Gallatin Ims. } \\
\text { Do. } \\
\text { Gallatin red sh. } \\
\text { Gallatin Ims. } \\
\text { Bighorn dolo. }\end{array}$ \\
\hline $\begin{array}{l}148 \\
173 \\
174 \\
197 \\
198\end{array}$ & $\begin{array}{l}2 \\
N \\
L \\
N \\
N\end{array}$ & $\begin{array}{l}\mathbf{N} \\
\mathbf{N} \\
\mathrm{N} \\
\mathrm{N} \\
\mathrm{N}\end{array}$ & $\begin{array}{l}\mathbf{N} \\
\mathbf{N} \\
\mathrm{N} \\
\mathrm{N} \\
\mathrm{N}\end{array}$ & $\begin{array}{r}\mathrm{N} \\
700 \\
N \\
700 \\
L\end{array}$ & $\begin{array}{c}\mathrm{L} \\
\mathrm{L} \\
10 \\
\mathrm{~L} \\
\mathrm{~L}\end{array}$ & $\begin{array}{l}\mathrm{N} \\
\mathrm{N} \\
\mathrm{L} \\
\mathrm{N} \\
\mathrm{N}\end{array}$ & $\begin{array}{r}100 \\
N \\
150 \\
10 \\
N\end{array}$ & $\begin{array}{r}19-39-105 \\
20-40-106 \\
20-40-106 \\
7-39-105 \\
6-39-105\end{array}$ & $\begin{array}{l}\text { Flachead ss. } \\
\text { Gallotin lms. } \\
\text { Flathead cglt. } \\
\text { Bighorn ss. } \\
\text { Bighorn dolo. }\end{array}$ \\
\hline $\begin{array}{l}199 \\
200 \\
454 \\
455 \\
456\end{array}$ & $\begin{array}{l}L \\
N \\
L \\
7 \\
5\end{array}$ & $\begin{array}{l}N \\
N \\
L \\
15 \\
10\end{array}$ & $\begin{array}{l}\mathrm{N} \\
\mathrm{N} \\
\mathrm{N} \\
5 \\
\mathrm{~L}\end{array}$ & $\begin{array}{r}150 \\
100 \\
N \\
200 \\
300\end{array}$ & $\begin{array}{c}\mathrm{L} \\
\mathrm{L} \\
\mathrm{L} \\
15 \\
10\end{array}$ & $\begin{array}{c}\mathrm{N} \\
\mathrm{N} \\
\mathrm{L} \\
10 \\
10\end{array}$ & $\begin{array}{r}\mathrm{L} \\
N \\
200 \\
70 \\
L\end{array}$ & $\begin{array}{l}32-40-105 \\
32-40-105 \\
26-41-107 \\
23-40-106 \\
14-40-106\end{array}$ & $\begin{array}{l}\text { Darby dolo. } \\
\text { Madison } 1 \mathrm{~ms} \text {. } \\
\text { Flathead ss. } \\
\text { Madison } 1 \mathrm{~ms} \text {, Fe st, bx. } \\
\text { Do. }\end{array}$ \\
\hline $\begin{array}{l}477 \\
484 \\
486 \\
487 \\
488\end{array}$ & $\begin{array}{l}N \\
L \\
70 \\
70 \\
70\end{array}$ & $\begin{array}{l}N \\
N \\
50 \\
30 \\
20\end{array}$ & $\begin{array}{l}\text { N } \\
\mathbf{L} \\
30 \\
70 \\
50\end{array}$ & $\begin{array}{l}L \\
L \\
L \\
L \\
N\end{array}$ & $\begin{array}{r}N \\
30 \\
700 \\
700 \\
700\end{array}$ & $\begin{array}{r}N \\
20 \\
30 \\
30 \\
50\end{array}$ & $\begin{array}{r}N \\
700 \\
150 \\
150 \\
300\end{array}$ & $\begin{array}{l}18-41-107 \\
17-41-107 \\
19-40-105 \\
19-40-105 \\
19-40-105\end{array}$ & $\begin{array}{l}\text { Bighorn dolo. } \\
\text { Flathead ss, fe st, bx. } \\
\text { Ansden oolites. } \\
\text { Do. } \\
\text { Do. }\end{array}$ \\
\hline $\begin{array}{l}489 \\
490 \\
510 \\
511 \\
829\end{array}$ & $\begin{array}{r}70 \\
70 \\
L \\
L \\
5\end{array}$ & $\begin{array}{r}20 \\
30 \\
N \\
N\end{array}$ & $\begin{array}{r}30 \\
70 \\
N \\
N \\
N\end{array}$ & $\begin{array}{r}N \\
N \\
150 \\
N \\
N\end{array}$ & $\begin{array}{r}100 \\
700 \\
L \\
L \\
20\end{array}$ & $\begin{array}{r}30 \\
70 \\
N \\
N \\
N\end{array}$ & $\begin{array}{r}300 \\
100 \\
N \\
150 \\
20\end{array}$ & $\begin{array}{r}19-40-105 \\
19-40-105 \\
1-39-106 \\
1-39 \quad 106 \\
10-40-106\end{array}$ & $\begin{array}{l}\text { Amsden red sh. } \\
\text { Amsden oolites. } \\
\text { Madison } t \text { ms. } \\
\text { Amsden lms. } \\
\text { Park City chert nodule. }\end{array}$ \\
\hline 830 & 5 & $\mathbf{L}$ & $\mathbf{N}$ & 150 & 20 & 30 & 20 & $11-40-106$ & Park City lms, fossils. \\
\hline
\end{tabular}

4) Contains 11.4 percent $\mathrm{Fe}_{2} \mathrm{O}_{3}$; Mo looked for but not detected.

5) Contains 56.0 percent $\mathrm{Fe}_{2} \mathrm{O}_{3}$; Mo detected but below determination limit.

6) Descriptions of formations are given in Table 1 and accompanying text. 
TABLE 6.-Analyses of felsic rock samples from

\begin{tabular}{|c|c|c|c|c|c|c|c|c|c|c|c|c|}
\hline \multirow[b]{2}{*}{ Sample } & \multicolumn{12}{|c|}{ Semiquantitative spectrographic analyses } \\
\hline & $\begin{array}{c}\mathrm{Fe} \\
(.05\rangle\end{array}$ & $\begin{array}{r}\mathrm{Mg} \\
(.02) \\
\end{array}$ & $\begin{array}{r}\text { Ca } \\
(.05) \\
\end{array}$ & $\begin{array}{c}\mathrm{Ti} \\
(.002)\end{array}$ & $\begin{array}{c}M n \\
(10)\end{array}$ & $\begin{array}{c}B \\
\text { (10) }\end{array}$ & $\begin{array}{c}82 \\
(20) \\
\end{array}$ & $\begin{array}{l}\mathrm{Be} \\
\text { (1) }\end{array}$ & $\begin{array}{l}\text { co } \\
\text { (5) }\end{array}$ & $\begin{array}{l}\mathrm{Cr} \\
(5)\end{array}$ & $\begin{array}{l}\mathrm{Cu} \\
\text { (5) }\end{array}$ & $\begin{array}{r}\mathrm{La} \\
(20) \\
\end{array}$ \\
\hline \multicolumn{13}{|c|}{ Granite samples } \\
\hline $\begin{array}{l}17 \\
20 \\
26 \\
28 \\
41\end{array}$ & $\begin{array}{r}2 \\
1.5 \\
.7 \\
.7 \\
.7\end{array}$ & $\begin{array}{l}0.5 \\
.3 \\
.15 \\
.1 \\
.1\end{array}$ & $\begin{array}{l}1 \\
.7 \\
.1 \\
.7 \\
.3\end{array}$ & $\begin{array}{r}0.15 \\
.07 \\
.03 \\
.03 \\
.05\end{array}$ & $\begin{array}{r}300 \\
300 \\
70 \\
100 \\
70\end{array}$ & $\begin{array}{l}\mathbf{N} \\
\mathbf{N} \\
\mathrm{N} \\
\mathrm{N} \\
\mathrm{N}\end{array}$ & $\begin{array}{r}1,000 \\
300 \\
150 \\
700 \\
500\end{array}$ & $\begin{array}{l}\mathrm{L} \\
3 \\
1 \\
1 \\
\mathrm{~L}\end{array}$ & $\begin{array}{c}7 \\
N \\
10 \\
N \\
N\end{array}$ & $\begin{array}{r}1 \\
5 \\
10 \\
N \\
N\end{array}$ & $\begin{array}{r}20 \\
15 \\
7 \\
15 \\
7\end{array}$ & $\begin{array}{r}50 \\
20 \\
N \\
N \\
30\end{array}$ \\
\hline $\begin{array}{l}44 \\
48 \\
49 \\
51 \\
52\end{array}$ & $\begin{array}{r}.7 \\
.7 \\
1.5 \\
.7 \\
1.5\end{array}$ & $\begin{array}{l}.2 \\
.2 \\
.5 \\
.07 \\
.3\end{array}$ & $\begin{array}{l}.3 \\
.2 \\
1.5 \\
.3\end{array}$ & $\begin{array}{l}.05 \\
.03 \\
.15 \\
.03 \\
.07\end{array}$ & $\begin{array}{r}50 \\
100 \\
200 \\
50 \\
150\end{array}$ & $\begin{array}{l}\mathrm{N} \\
\mathrm{N} \\
\mathrm{N} \\
\mathrm{N} \\
\mathrm{N}\end{array}$ & $\begin{array}{l}700 \\
700 \\
700 \\
300 \\
500\end{array}$ & $\begin{array}{l}\mathrm{L} \\
\mathrm{L} \\
1 \\
1\end{array}$ & $\begin{array}{l}L \\
L \\
5 \\
N \\
L\end{array}$ & $\begin{array}{l}\mathrm{N} \\
\mathrm{N} \\
\mathrm{L} \\
\mathrm{N} \\
\mathrm{N}\end{array}$ & $\begin{array}{r}5 \\
5 \\
7 \\
5 \\
10\end{array}$ & $\begin{array}{r}30 \\
\mathrm{~N} \\
30 \\
100 \\
20\end{array}$ \\
\hline $\begin{array}{l}61 \\
63 \\
74 \\
75 \\
78\end{array}$ & $\begin{array}{l}1 \\
2 \\
1.5 \\
.3 \\
5\end{array}$ & $\begin{array}{l}.3 \\
.3 \\
.2 \\
.1 \\
3^{-1}\end{array}$ & $\begin{array}{l}.7 \\
1_{3}^{.7}\end{array}$ & $\begin{array}{l}.07 \\
.1 \\
.07 \\
.03 \\
.2\end{array}$ & $\begin{array}{l}100 \\
150 \\
300 \\
150 \\
500\end{array}$ & $\begin{array}{l}\mathrm{N} \\
\mathrm{N} \\
\mathrm{N} \\
\mathrm{N} \\
\mathrm{N}\end{array}$ & $\begin{array}{r}700 \\
700 \\
700 \\
200 \\
1,500\end{array}$ & $\begin{array}{l}\text { I } \\
\text { L } \\
3_{3} \cdot 5 \\
2\end{array}$ & $\begin{array}{r}\mathrm{L} \\
\mathbf{N} \\
\mathrm{N} \\
\mathbf{N}\end{array}$ & $\begin{array}{r}10 \\
5 \\
\mathrm{~L} \\
\mathrm{~N} \\
70\end{array}$ & $\begin{array}{r}5 \\
5 \\
10 \\
5 \\
5\end{array}$ & $\begin{array}{r}20 \\
30 \\
70 \\
70 \\
200\end{array}$ \\
\hline $\begin{array}{l}80 \\
82 \\
83 \\
84 \\
85\end{array}$ & $\begin{array}{l}1.5 \\
.7 \\
.7 \\
3 \\
3\end{array}$ & $\begin{array}{l}.3 \\
.2 \\
.1 \\
.7 \\
.7\end{array}$ & $\begin{array}{l}.7 \\
1.5 \\
1.5\end{array}$ & $\begin{array}{l}.1 \\
.05 \\
.03 \\
.15 \\
.2\end{array}$ & $\begin{array}{l}300 \\
100 \\
100 \\
200 \\
300\end{array}$ & $\begin{array}{l}\mathrm{N} \\
\mathrm{N} \\
\mathrm{N} \\
\mathrm{N} \\
\mathrm{N}\end{array}$ & $\begin{array}{l}500 \\
700 \\
700 \\
700 \\
700\end{array}$ & $\begin{array}{l}1 \\
1 \\
1 \\
1 \\
1\end{array}$ & $\begin{array}{r}\mathbf{L} \\
\mathbf{N} \\
\mathrm{N} \\
10 \\
10\end{array}$ & $\begin{array}{l}\text { L } \\
\text { N } \\
\text { H } \\
7 \\
7\end{array}$ & $\begin{array}{r}5 \\
10 \\
7 \\
10 \\
7\end{array}$ & $\begin{array}{r}30 \\
100 \\
20 \\
50 \\
50\end{array}$ \\
\hline $\begin{array}{l}86 \\
93 \\
94 \\
95 \\
97\end{array}$ & $\begin{array}{l}1.5 \\
1.5 \\
1.5 \\
1.5 \\
1\end{array}$ & $\begin{array}{l}.5 \\
.7 \\
.5 \\
.15 \\
.15\end{array}$ & $\begin{array}{l}.3 \\
.3 \\
.5 \\
.7 \\
.5\end{array}$ & $\begin{array}{l}.1 \\
.15 \\
.1 \\
.05 \\
.1\end{array}$ & $\begin{array}{r}100 \\
100 \\
70 \\
70 \\
70\end{array}$ & $\begin{array}{l}\mathrm{N} \\
\mathrm{N} \\
\mathrm{N} \\
\mathrm{N} \\
\mathrm{N}\end{array}$ & $\begin{array}{r}700 \\
30 \\
700 \\
700 \\
700\end{array}$ & $\begin{array}{l}\mathrm{L} \\
\mathbf{L} \\
\mathbf{L} \\
\mathbf{L}\end{array}$ & $\begin{array}{r}5 \\
30 \\
N \\
N \\
N\end{array}$ & $\begin{array}{l}\text { H } \\
\mathbf{L} \\
\mathbf{L} \\
\mathbf{L} \\
\mathbf{L}\end{array}$ & $\begin{array}{l}\text { L } \\
7 \\
5 \\
7 \\
5\end{array}$ & $\begin{array}{l}70 \\
70 \\
30 \\
50 \\
70\end{array}$ \\
\hline $\begin{array}{r}98 \\
99 \\
100 \\
102 \\
104\end{array}$ & $\begin{array}{l}1.5 \\
1.5 \\
1.5 \\
1.5 \\
1.5\end{array}$ & $\begin{array}{l}.15 \\
.2 \\
.15 \\
.3 \\
.5\end{array}$ & $\begin{array}{l}.7 \\
.7 \\
.7 \\
.7\end{array}$ & $\begin{array}{l}.1 \\
.1 \\
.07 \\
.15 \\
.1\end{array}$ & $\begin{array}{r}100 \\
70 \\
70 \\
150 \\
150\end{array}$ & $\begin{array}{l}\mathrm{N} \\
\mathrm{N} \\
\mathrm{N} \\
\mathrm{N} \\
\mathrm{N}\end{array}$ & $\begin{array}{r}1,000 \\
700 \\
1,000 \\
100 \\
700\end{array}$ & $\begin{array}{l}L \\
1 \\
L \\
1 \\
1\end{array}$ & $\begin{array}{l}\mathrm{N} \\
\mathrm{N} \\
\mathrm{N} \\
\mathrm{N} \\
5\end{array}$ & $\begin{array}{l}\mathrm{N} \\
\mathrm{N} \\
\mathrm{N} \\
\mathrm{L} \\
5\end{array}$ & $\begin{array}{l}L \\
7 \\
L \\
7 \\
5\end{array}$ & $\begin{array}{r}50 \\
50 \\
100 \\
20 \\
30\end{array}$ \\
\hline $\begin{array}{l}109 \\
119 \\
121 \\
124 \\
126\end{array}$ & $\begin{array}{l}.2 \\
2^{.7} \\
.1\end{array}$ & $\begin{array}{l}.07 \\
.2 \\
.7 \\
.5 \\
.07\end{array}$ & $\begin{array}{r}.2 \\
.7 \\
.7 \\
.2\end{array}$ & $\begin{array}{l}.02 \\
.05 \\
.1 \\
.15 \\
.015\end{array}$ & $\begin{array}{r}70 \\
70 \\
150 \\
150 \\
15\end{array}$ & $\begin{array}{l}N \\
N \\
N \\
L \\
N\end{array}$ & $\begin{array}{r}150 \\
300 \\
100 \\
700 \\
L\end{array}$ & $\begin{array}{l}\text { l } \\
\text { L } \\
\text { L } \\
\text { L } \\
\text { N }\end{array}$ & $\begin{array}{r}\mathrm{N} \\
\mathrm{N} \\
10 \\
7 \\
\mathrm{~N}\end{array}$ & $\begin{array}{r}\mathrm{N} \\
\mathrm{L} \\
20 \\
5 \\
\mathrm{~N}\end{array}$ & $\begin{array}{r}10 \\
7 \\
10 \\
L \\
L\end{array}$ & $\begin{array}{r}\mathrm{N} \\
20 \\
\mathrm{~L} \\
\mathrm{~L} \\
\mathrm{~N}\end{array}$ \\
\hline $\begin{array}{l}129 \\
130 \\
131 \\
156 \\
157\end{array}$ & $\begin{array}{l}2 \\
1.5 \\
1.5 \\
1 \\
1\end{array}$ & $\begin{array}{l}.5 \\
.2 \\
.3 \\
.3 \\
.5\end{array}$ & $\begin{array}{l}.7 \\
1 \\
.3 \\
.3\end{array}$ & $\begin{array}{l}.15 \\
.1 \\
.15 \\
.05 \\
.07\end{array}$ & $\begin{array}{r}200 \\
70 \\
100 \\
100 \\
70\end{array}$ & $\begin{array}{l}\mathrm{N} \\
\mathrm{N} \\
\mathrm{N} \\
\mathrm{N} \\
\mathrm{N}\end{array}$ & $\begin{array}{l}100 \\
300 \\
700 \\
700 \\
150\end{array}$ & $\begin{array}{l}\mathbf{I} \\
\mathbf{L} \\
\mathbf{I} \\
\mathbf{1} \\
\mathrm{L}\end{array}$ & $\begin{array}{l}5 \\
7 \\
5 \\
N \\
N\end{array}$ & $\begin{array}{r}10 \\
7 \\
\mathrm{~L} \\
\mathrm{~L} \\
\mathrm{~L}\end{array}$ & $\begin{array}{r}7 \\
15 \\
\text { L } \\
\text { L } \\
\text { L }\end{array}$ & $\begin{array}{l}30 \\
20 \\
30 \\
30 \\
50\end{array}$ \\
\hline $\begin{array}{l}160 \\
161 \\
162 \\
163 \\
164\end{array}$ & $\begin{array}{l}1.5 \\
2 \\
1.5 \\
1 \\
3\end{array}$ & $\begin{array}{r}.2 \\
.3 \\
.7 \\
.1\end{array}$ & $\begin{array}{l}.3 \\
.5 \\
.3 \\
.7 \\
.7\end{array}$ & $\begin{array}{l}.15 \\
.15 \\
.15 \\
.05 \\
.3\end{array}$ & $\begin{array}{l}150 \\
200 \\
100 \\
150 \\
300\end{array}$ & $\begin{array}{l}\mathrm{N} \\
\mathrm{N} \\
\mathrm{N} \\
\mathrm{N} \\
\mathrm{N}\end{array}$ & $\begin{array}{l}700 \\
300 \\
700 \\
150 \\
700\end{array}$ & $\begin{array}{l}L \\
L \\
1 \\
1 \\
1\end{array}$ & $\begin{array}{r}L \\
L \\
5 \\
N \\
15\end{array}$ & $\begin{array}{r}\text { N } \\
\mathbf{L} \\
5 \\
\mathbf{L} \\
15\end{array}$ & $\begin{array}{r}10 \\
10 \\
1 \\
10 \\
7\end{array}$ & $\begin{array}{r}70 \\
20 \\
20 \\
30 \\
L\end{array}$ \\
\hline $\begin{array}{l}165 \\
170 \\
171 \\
177 \\
178\end{array}$ & $\begin{array}{l}2 \\
1.5 \\
.2 \\
1 \\
3\end{array}$ & $\begin{array}{l}.5 \\
.5 \\
.07 \\
.2 \\
.7\end{array}$ & $\begin{array}{l}1 \\
1.7 \\
.2\end{array}$ & $\begin{array}{l}.2 \\
.1 \\
.02 \\
.05 \\
.2\end{array}$ & $\begin{array}{r}200 \\
100 \\
30 \\
100 \\
300\end{array}$ & $\begin{array}{l}\mathrm{N} \\
\mathrm{N} \\
\mathrm{N} \\
\mathrm{N} \\
\mathrm{N}\end{array}$ & $\begin{array}{l}700 \\
700 \\
700 \\
200 \\
300\end{array}$ & $\begin{array}{l}\mathrm{L} \\
\mathrm{I} \\
\mathrm{L} \\
\mathrm{I} \\
\mathrm{I}\end{array}$ & $\begin{array}{c}10 \\
L \\
N \\
N \\
10\end{array}$ & $\begin{array}{r}7 \\
10 \\
\mathrm{~N} \\
\mathrm{~N} \\
\mathrm{~N}\end{array}$ & $\begin{array}{r}5 \\
L \\
5 \\
5 \\
15\end{array}$ & $\begin{array}{r}30 \\
100 \\
50 \\
50 \\
20\end{array}$ \\
\hline $\begin{array}{l}179 \\
180 \\
190 \\
401 \\
403\end{array}$ & $\begin{array}{l}2^{.3} \\
3 \\
1.5\end{array}$ & $\begin{array}{l}1.7 \\
3.7 \\
.3 \\
.3\end{array}$ & $\begin{array}{l}3 \\
.3 \\
.3 \\
.3 \\
.5\end{array}$ & $\begin{array}{l}.15 \\
.15 \\
.15 \\
.1 \\
.1\end{array}$ & $\begin{array}{r}50 \\
70 \\
200 \\
100 \\
100\end{array}$ & $\begin{array}{l}\mathrm{L} \\
\mathrm{L} \\
\mathrm{N} \\
\mathrm{N} \\
\mathrm{N}\end{array}$ & $\begin{array}{r}70 \\
700 \\
70 \\
700 \\
700\end{array}$ & $\begin{array}{l}1 \\
\mathbf{L} \\
\mathbf{1} \\
1 \\
1\end{array}$ & $\begin{array}{r}N \\
5 \\
10 \\
7 \\
5\end{array}$ & $\begin{array}{r}7 \\
7 \\
30 \\
10 \\
L\end{array}$ & $\begin{array}{r}7 \\
20 \\
10 \\
10 \\
20\end{array}$ & $\begin{array}{r}50 \\
N \\
70 \\
30 \\
100\end{array}$ \\
\hline
\end{tabular}

1 Contains $700 \mathrm{ppm}$ Mo. 


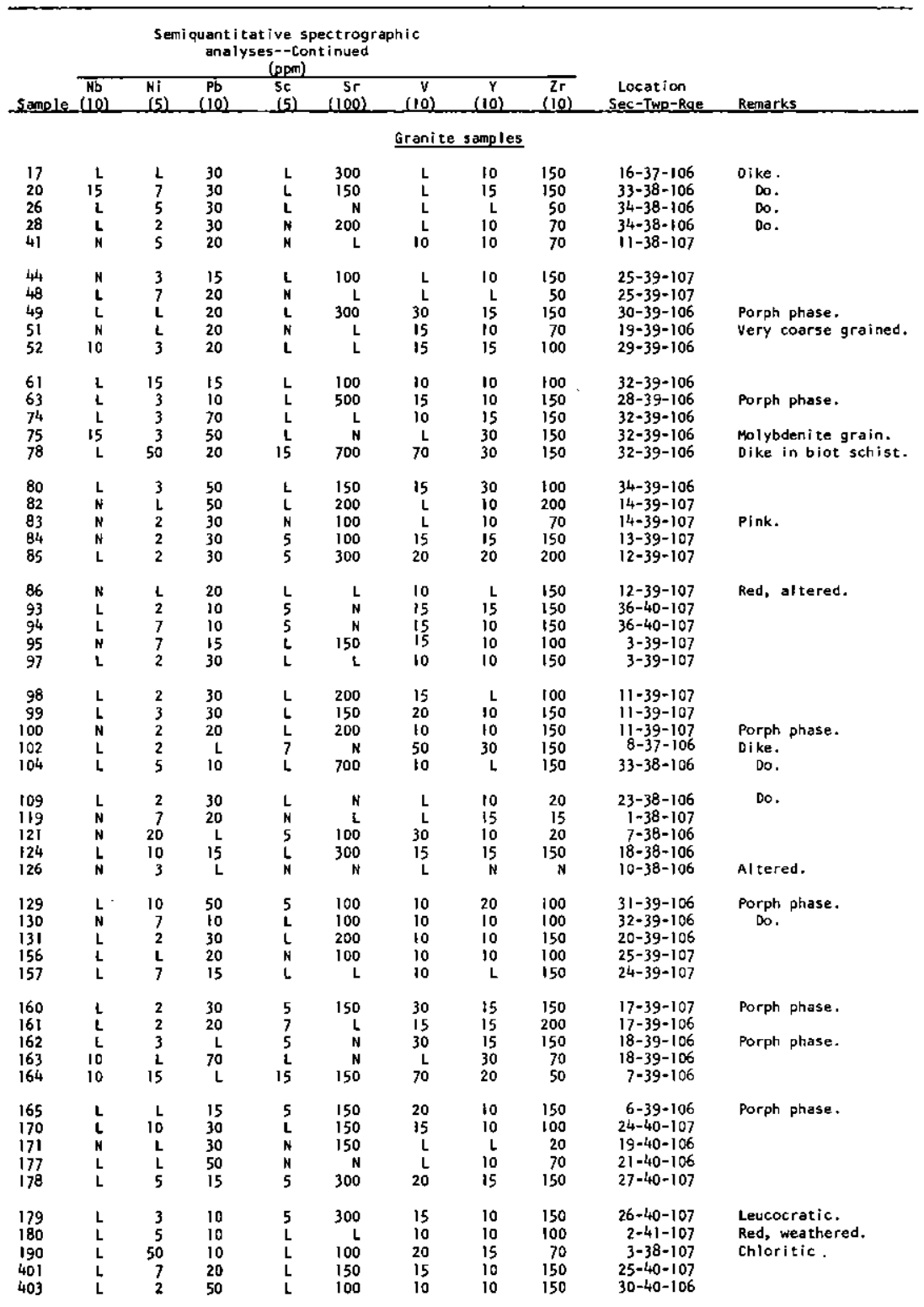


TABLE 6.-Analyses of felsic rock samples from the

\begin{tabular}{|c|c|c|c|c|c|c|c|c|c|c|c|c|}
\hline \multirow[b]{2}{*}{ Sample } & \multicolumn{12}{|c|}{ Semiquantitative spectrographic analyses } \\
\hline & $\begin{array}{c}\mathrm{Fe} \\
(.05)\end{array}$ & $\begin{array}{c}\mathrm{Mg} \\
(.02) \\
\end{array}$ & $\begin{array}{c}\text { Ca } \\
(.05) \\
\end{array}$ & $\begin{array}{c}\mathrm{Ti} \\
(.002)\end{array}$ & $\begin{array}{c}\mathrm{Mn} \\
(10)\end{array}$ & $\begin{array}{c}8 \\
(10) \\
\end{array}$ & $\begin{array}{r}8 \mathrm{Ba} \\
(20) \\
\end{array}$ & $\begin{array}{l}\text { Be } \\
\text { (1) }\end{array}$ & $\begin{array}{l}\text { Co } \\
(5)\end{array}$ & $\begin{array}{l}c r \\
(5)\end{array}$ & $\begin{array}{l}\text { Cu } \\
\text { (5) }\end{array}$ & $\begin{array}{r}\text { La } \\
(20) \\
\end{array}$ \\
\hline \multicolumn{13}{|c|}{ Granite samples--Continued } \\
\hline $\begin{array}{l}404 \\
405 \\
407 \\
409 \\
414\end{array}$ & $\begin{array}{l}1 \\
1.5 \\
1.5 \\
2\end{array}$ & $\begin{array}{l}0.15 \\
.3 \\
.5 \\
.1 \\
.5\end{array}$ & $\begin{array}{r}0.7 \\
.1 \\
.5 \\
.7 \\
1\end{array}$ & $\begin{array}{l}0.03 \\
.05 \\
.1 \\
.07 \\
.15\end{array}$ & $\begin{array}{l}100 \\
100 \\
100 \\
100 \\
150\end{array}$ & $\begin{array}{l}\mathrm{N} \\
\mathrm{N} \\
\mathrm{N} \\
\mathrm{N} \\
\mathrm{N}\end{array}$ & $\begin{array}{l}700 \\
500 \\
700 \\
500 \\
700\end{array}$ & $\begin{array}{l}1.5 \\
i \\
1 \\
1 \\
1\end{array}$ & $\begin{array}{l}\text { L } \\
\text { N } \\
\text { L } \\
\text { N } \\
5\end{array}$ & $\begin{array}{l}\mathrm{L} \\
\mathrm{N} \\
\mathrm{L} \\
\mathrm{N} \\
7\end{array}$ & $\begin{array}{r}15 \\
20 \\
5 \\
10 \\
20\end{array}$ & $\begin{array}{l}70 \\
30 \\
20 \\
70 \\
30\end{array}$ \\
\hline $\begin{array}{l}424 \\
430 \\
434 \\
473 \\
485\end{array}$ & $\begin{array}{l}1 \\
1 \\
1 \\
.15 \\
.7\end{array}$ & $\begin{array}{l}.2 \\
.15 \\
.7 \\
.07 \\
.15\end{array}$ & $\begin{array}{r}.7 \\
.7 \\
.3 \\
.3\end{array}$ & $\begin{array}{l}.05 \\
.07 \\
.15 \\
.01 \\
.05\end{array}$ & $\begin{array}{r}100 \\
100 \\
100 \\
20 \\
100\end{array}$ & $\begin{array}{l}\mathrm{N} \\
\mathrm{N} \\
\mathrm{N} \\
\mathrm{N} \\
\mathrm{N}\end{array}$ & $\begin{array}{r}700 \\
700 \\
50 \\
1,500 \\
300\end{array}$ & $\begin{array}{l}1 \\
2 \\
1 \\
L\end{array}$ & $\begin{array}{l}\mathrm{N} \\
\mathrm{N} \\
5 \\
\mathrm{~N} \\
\mathrm{~N}\end{array}$ & $\begin{array}{l}\mathrm{N} \\
\mathrm{N} \\
7 \\
7 \\
\mathrm{~N}\end{array}$ & $\begin{array}{r}15 \\
5 \\
30 \\
10 \\
L\end{array}$ & $\begin{array}{r}N \\
L \\
70 \\
30 \\
L\end{array}$ \\
\hline $\begin{array}{l}517 \\
518 \\
521 \\
522 \\
531\end{array}$ & $\begin{array}{l}1.5 \\
5 \\
3 \\
.7 \\
.7\end{array}$ & $\begin{array}{l}.5 \\
.07 \\
.05 \\
.1 \\
.1\end{array}$ & $\begin{array}{l}.7 \\
.15 \\
.05 \\
.15 \\
.5\end{array}$ & $\begin{array}{l}.1 \\
.15 \\
.05 \\
.03 \\
.05\end{array}$ & $\begin{array}{r}150 \\
70 \\
70 \\
70 \\
50\end{array}$ & $\begin{array}{c}10 \\
\mathrm{~N} \\
\mathrm{~N} \\
\mathrm{~L} \\
\mathrm{~N}\end{array}$ & $\begin{array}{r}1,500 \\
\mathbf{I}, 500 \\
150 \\
700 \\
700\end{array}$ & $\begin{array}{r}N \\
L \\
L \\
1 \\
1.5\end{array}$ & $\begin{array}{c}N \\
L \\
10 \\
N \\
L\end{array}$ & $\begin{array}{l}\text { L } \\
\text { N } \\
\text { L } \\
\text { N } \\
\text { N }\end{array}$ & $\begin{array}{c}15 \\
15 \\
\mathrm{~L} \\
15 \\
\mathrm{~N}\end{array}$ & $\begin{array}{l}30 \\
\mathrm{~L} \\
\mathrm{~N} \\
\mathrm{~N} \\
\mathrm{~N}\end{array}$ \\
\hline $\begin{array}{l}537 \\
549 \\
805 \\
807 \\
808\end{array}$ & $\begin{array}{r}7 \\
1.5 \\
.5 \\
.7 \\
1.5\end{array}$ & $\begin{array}{l}1.5 \\
.3 \\
.15 \\
.15 \\
.3\end{array}$ & $\begin{array}{l}.2 \\
.7 \\
.07 \\
.5 \\
.07\end{array}$ & $\begin{array}{l}.2 \\
.15 \\
.03 \\
.07 \\
.1\end{array}$ & $\begin{array}{r}300 \\
100 \\
20 \\
50 \\
50\end{array}$ & $\begin{array}{l}\mathbf{N} \\
\mathrm{N} \\
\mathrm{N} \\
\mathrm{N} \\
\mathrm{N}\end{array}$ & $\begin{array}{r}1,500 \\
1,000 \\
700 \\
1,500 \\
1,000\end{array}$ & $\begin{array}{l}N \\
L \\
L \\
L \\
1\end{array}$ & $\begin{array}{r}100 \\
L \\
N \\
N \\
L\end{array}$ & $\begin{array}{l}70 \\
N \\
L \\
N \\
L\end{array}$ & $\begin{array}{r}10 \\
10 \\
20 \\
L \\
20\end{array}$ & $\begin{array}{r}N \\
50 \\
30 \\
L \\
L\end{array}$ \\
\hline $\begin{array}{l}854 \\
864 \\
880 \\
891 \\
897\end{array}$ & $\begin{array}{l}1 \\
1.5 \\
5 \\
3 \\
1\end{array}$ & $\begin{array}{l}.2 \\
.2 \\
1 \\
.7\end{array}$ & $\begin{array}{l}1 \\
1.5 \\
1.5 \\
1.5 \\
1\end{array}$ & $\begin{array}{l}.05 \\
.07 \\
.15 \\
.2 \\
.15\end{array}$ & $\begin{array}{l}150 \\
100 \\
300 \\
300 \\
200\end{array}$ & $\begin{array}{l}\mathrm{N} \\
\mathrm{N} \\
\mathrm{N} \\
\mathrm{N} \\
\mathrm{N}\end{array}$ & $\begin{array}{r}700 \\
1,000 \\
1,500 \\
1,000 \\
1,000\end{array}$ & $\begin{array}{l}\mathrm{L} \\
1 \\
\mathrm{~L} \\
\mathrm{~N} \\
\mathrm{~L}\end{array}$ & $\begin{array}{r}7 \\
\mathrm{~N} \\
15 \\
7 \\
\mathrm{~N}\end{array}$ & $\begin{array}{r}\mathrm{L} \\
\mathrm{L} \\
7 \\
10 \\
\mathrm{~L}\end{array}$ & $\begin{array}{r}5 \\
5 \\
7 \\
20 \\
50\end{array}$ & $\begin{array}{r}20 \\
\mathrm{~N} \\
100 \\
70 \\
20\end{array}$ \\
\hline 898 & 3 & .7 & 1.5 & .15 & 200 & N & 1,000 & L & 7 & 10 & 20 & 70 \\
\hline \multicolumn{13}{|c|}{ Pegmotite and aplite samples } \\
\hline $\begin{array}{l}12 \\
14 \\
182 \\
27 \\
29\end{array}$ & $\begin{array}{r}0.3 \\
.3 \\
.7 \\
.2 \\
1.5\end{array}$ & $\begin{array}{c}0.15 \\
.3 \\
.07 \\
.05 \\
.5\end{array}$ & $\begin{array}{c}0.5 \\
1.5 \\
.3 \\
.15 \\
1\end{array}$ & $\begin{array}{l}0.015 \\
.03 \\
.03 \\
.01 \\
.15\end{array}$ & $\begin{array}{r}150 \\
100 \\
70 \\
20 \\
150\end{array}$ & $\begin{array}{l}\mathrm{N} \\
\mathrm{N} \\
\mathrm{N} \\
\mathrm{N} \\
\mathrm{L}\end{array}$ & $\begin{array}{r}100 \\
70 \\
L \\
70 \\
300\end{array}$ & $\begin{array}{l}2 \\
3 \\
3 \\
L \\
L\end{array}$ & $\begin{array}{c}\mathrm{N} \\
\mathrm{N} \\
\mathrm{N} \\
\mathrm{N} \\
\mathrm{N}\end{array}$ & $\begin{array}{r}7 \\
30 \\
L \\
L \\
5\end{array}$ & $\begin{array}{r}10 \\
5 \\
L \\
5 \\
10\end{array}$ & $\begin{array}{l}N \\
N \\
L \\
N \\
L\end{array}$ \\
\hline $\begin{array}{l}33 \\
50 \\
58 \\
62 \\
77\end{array}$ & $\begin{array}{l}1 \\
.15 \\
1.5 \\
.7 \\
.7\end{array}$ & $\begin{array}{l}.3 \\
.02 \\
.1 \\
.2 \\
.3\end{array}$ & $\begin{array}{l}1 \\
.05 \\
.5 \\
.7 \\
1\end{array}$ & $\begin{array}{l}.1 \\
.003 \\
.02 \\
.03 \\
.02\end{array}$ & $\begin{array}{r}300 \\
100 \\
70 \\
100 \\
50\end{array}$ & $\begin{array}{c}\mathrm{N} \\
\mathrm{N} \\
\mathrm{N} \\
\mathrm{N} \\
10\end{array}$ & $\begin{array}{l}700 \\
300 \\
500 \\
200 \\
150\end{array}$ & $\begin{array}{l}1 \\
N \\
3 \\
3 \\
1\end{array}$ & $\begin{array}{l}\text { L } \\
\text { N } \\
\text { N } \\
\text { L } \\
\text { N }\end{array}$ & $\begin{array}{l}5 \\
N \\
N \\
L \\
L\end{array}$ & $\begin{array}{l}5 \\
L \\
5 \\
7 \\
5\end{array}$ & $\begin{array}{r}150 \\
N \\
30 \\
20 \\
N\end{array}$ \\
\hline $\begin{array}{r}81 \\
105 \\
107 \\
113 \\
120\end{array}$ & $\begin{array}{l}.3 \\
1.5 \\
1.5 \\
.7\end{array}$ & $\begin{array}{l}.1 \\
.3 \\
.02 \\
1.2 \\
.2\end{array}$ & $\begin{array}{l}.2 \\
.7 \\
.3 \\
.3 \\
.5\end{array}$ & $\begin{array}{l}.007 \\
.07 \\
.002 \\
.1 \\
.03\end{array}$ & $\begin{array}{r}70 \\
150 \\
30 \\
150 \\
50\end{array}$ & $\begin{array}{l}\mathrm{N} \\
\mathrm{N} \\
\mathrm{N} \\
\mathrm{N} \\
\mathrm{N}\end{array}$ & $\begin{array}{r}\mathrm{L} \\
500 \\
70 \\
\mathrm{~L} \\
500\end{array}$ & $\begin{array}{l}1 \\
2 \\
3 \\
1 \\
1\end{array}$ & $\begin{array}{l}\text { N } \\
\text { L } \\
\text { N } \\
7 \\
\text { N }\end{array}$ & $\begin{array}{l}\mathrm{N} \\
7 \\
\mathrm{~N} \\
\mathrm{~L} \\
\mathrm{~L}\end{array}$ & $\begin{array}{r}\mathbf{L} \\
\mathbf{L} \\
7 \\
10 \\
\mathrm{~N}\end{array}$ & $\begin{array}{r}N \\
20 \\
N \\
L \\
20\end{array}$ \\
\hline $\begin{array}{l}123 \\
134 \\
135 \\
154 \\
159\end{array}$ & $\begin{array}{l}3 \\
.7 \\
.7 \\
.2 \\
.15\end{array}$ & $\begin{array}{l}.1 \\
.2 \\
.1 \\
.2\end{array}$ & $\begin{array}{l}1 \\
.2 \\
.5 \\
.1 \\
.2\end{array}$ & $\begin{array}{l}.2 \\
.02 \\
.07 \\
.02 \\
.015\end{array}$ & $\begin{array}{r}300 \\
30 \\
70 \\
10 \\
30\end{array}$ & $\begin{array}{l}\mathrm{N} \\
\mathrm{N} \\
\mathrm{N} \\
\mathrm{N} \\
\mathrm{N}\end{array}$ & $\begin{array}{r}300 \\
300 \\
700 \\
200 \\
L\end{array}$ & $\begin{array}{l}1 \\
2 \\
2 \\
L \\
L\end{array}$ & $\begin{array}{l}15 \\
\mathrm{~N} \\
\mathrm{~N} \\
\mathrm{~N} \\
\mathrm{~N}\end{array}$ & $\begin{array}{l}70 \\
\mathrm{~N} \\
\mathrm{~N} \\
\mathrm{~N} \\
\mathrm{~N}\end{array}$ & $\begin{array}{r}10 \\
5 \\
1 \\
5 \\
7\end{array}$ & $\begin{array}{r}70 \\
N \\
30 \\
N \\
N\end{array}$ \\
\hline $\begin{array}{l}176 \\
188 \\
189 \\
4123 \\
421\end{array}$ & $\begin{array}{r}.7 \\
.7 \\
.7 \\
.5 \\
.7\end{array}$ & $\begin{array}{l}.15 \\
.3 \\
.07 \\
.1 \\
.2\end{array}$ & $\begin{array}{l}.7 \\
.1 \\
.2 \\
.1 \\
.2\end{array}$ & $\begin{array}{l}.03 \\
.03 \\
.15 \\
.02 \\
.007\end{array}$ & $\begin{array}{r}100 \\
30 \\
30 \\
50 \\
15\end{array}$ & $\begin{array}{l}\mathrm{N} \\
\mathrm{N} \\
\mathrm{N} \\
\mathrm{N} \\
\mathrm{N}\end{array}$ & $\begin{array}{r}700 \\
L \\
700 \\
L \\
200\end{array}$ & $\begin{array}{l}1 \\
2 \\
1 \\
3 \\
1.5\end{array}$ & $\begin{array}{l}\mathbf{N} \\
\mathbf{N} \\
\mathbf{N} \\
\mathbf{N} \\
\mathrm{N}\end{array}$ & $\begin{array}{l}\mathrm{N} \\
7 \\
\mathbf{L} \\
\mathrm{N} \\
\mathbf{L}\end{array}$ & $\begin{array}{r}7 \\
10 \\
15 \\
15 \\
7\end{array}$ & $\begin{array}{c}30 \\
L \\
L \\
N \\
N\end{array}$ \\
\hline $\begin{array}{l}423 \\
457 \\
458 \\
469 \\
471\end{array}$ & $\begin{array}{l}1.5 \\
.15 \\
.7 \\
.7 \\
1.5\end{array}$ & $\begin{array}{l}.1 \\
.03 \\
.03 \\
.07 \\
.1\end{array}$ & $\begin{array}{l}1 \\
.07 \\
.15 \\
.2 \\
.7\end{array}$ & $\begin{array}{l}.05 \\
.007 \\
.01 \\
.02 \\
.02\end{array}$ & $\begin{array}{r}150 \\
50 \\
70 \\
70 \\
100\end{array}$ & $\begin{array}{l}\mathrm{N} \\
\mathrm{N} \\
\mathrm{N} \\
\mathrm{N} \\
\mathrm{N}\end{array}$ & $\begin{array}{r}300 \\
1,000 \\
300 \\
L \\
L\end{array}$ & $\begin{array}{r}2 \\
L \\
2 \\
3 \\
1.5\end{array}$ & $\begin{array}{l}\mathrm{N} \\
\mathrm{N} \\
\mathrm{N} \\
\mathrm{N} \\
\mathrm{N}\end{array}$ & $\begin{array}{r}\mathrm{L} \\
\mathrm{L} \\
15 \\
7 \\
7\end{array}$ & $\begin{array}{l}15 \\
30 \\
15 \\
15 \\
10\end{array}$ & $\begin{array}{l}\mathrm{L} \\
\mathbf{N} \\
\mathrm{L} \\
\mathrm{N} \\
\mathrm{N}\end{array}$ \\
\hline
\end{tabular}

2) Contsins $20 \mathrm{ppm} \mathrm{Sn}$.

3) Contains $100 \mathrm{ppm} \mathrm{Sn}$. 


\begin{tabular}{|c|c|c|c|c|c|c|c|c|c|c|}
\hline \multirow[b]{2}{*}{ Sample } & \multicolumn{8}{|c|}{$\begin{array}{c}\text { Semi quant itat ive spect rograph ic } \\
\text { analyses--Cont i nued } \\
\text { (ppm) }\end{array}$} & \multirow[b]{2}{*}{$\begin{array}{c}\text { Location } \\
\text { Sec-Twp-Rge }\end{array}$} & \multirow[b]{2}{*}{ Remarks } \\
\hline & $\begin{array}{l}\mathrm{Nb} \\
(10)\end{array}$ & $\begin{array}{l}\mathrm{Ni} \\
(5)\end{array}$ & $\begin{array}{c}\mathrm{Pb} \\
(10) \\
\end{array}$ & $\begin{array}{l}5 c \\
(5)\end{array}$ & $\begin{array}{c}5 r \\
(100)\end{array}$ & $\begin{array}{c}v \\
(10)\end{array}$ & $\begin{array}{c}Y \\
(10)\end{array}$ & $\begin{array}{l}2 r \\
(10) \\
\end{array}$ & & \\
\hline \multicolumn{11}{|c|}{ Granite samples--Cont inued } \\
\hline $\begin{array}{l}404 \\
405 \\
407 \\
409 \\
414\end{array}$ & $\begin{array}{l}L \\
L \\
L \\
N \\
L\end{array}$ & $\begin{array}{l}2 \\
\mathrm{~L} \\
5 \\
2 \\
7\end{array}$ & $\begin{array}{r}70 \\
15 \\
\mathrm{~L} \\
30 \\
15\end{array}$ & $\begin{array}{l}\mathrm{L} \\
\mathrm{N} \\
\mathrm{L} \\
\mathrm{L} \\
5\end{array}$ & $\begin{array}{r}100 \\
N \\
100 \\
100 \\
200\end{array}$ & $\begin{array}{r}10 \\
L \\
15 \\
L \\
30\end{array}$ & $\begin{array}{c}\mathrm{L} \\
\mathrm{L} \\
\mathrm{N} \\
10 \\
\mathrm{~L}\end{array}$ & $\begin{array}{l}100 \\
100 \\
150 \\
100 \\
150\end{array}$ & $\begin{array}{l}30-40-106 \\
29-40-106 \\
21-40-106 \\
21-40-107 \\
35-41-107\end{array}$ & $\begin{array}{l}\text { PInk. } \\
\text { Near fault. }\end{array}$ \\
\hline $\begin{array}{l}424 \\
430 \\
434 \\
473 \\
485\end{array}$ & $\begin{array}{l}L \\
N \\
L \\
N \\
N\end{array}$ & $\begin{array}{l}L \\
L \\
L \\
L \\
5\end{array}$ & $\begin{array}{r}30 \\
15 \\
\mathrm{~L} \\
15 \\
\mathrm{~L}\end{array}$ & $\begin{array}{l}\mathrm{N} \\
\mathrm{N} \\
5 \\
\mathrm{~N} \\
\mathrm{~N}\end{array}$ & $\begin{array}{r}\mathrm{L} \\
150 \\
\mathrm{~N} \\
300 \\
\mathrm{~N}\end{array}$ & $\begin{array}{r}L \\
L \\
20 \\
L \\
10\end{array}$ & $\begin{array}{r}L \\
L \\
20 \\
N \\
N\end{array}$ & $\begin{array}{r}150 \\
70 \\
150 \\
N \\
70\end{array}$ & $\begin{array}{l}35-39-107 \\
35-38-107 \\
25-38-107 \\
31-41-108 \\
17-41-107\end{array}$ & $\begin{array}{l}\text { Porph phase. } \\
\text { Do. } \\
\text { Fine grained. } \\
\text { Red, oxidized. }\end{array}$ \\
\hline $\begin{array}{l}517 \\
518 \\
521 \\
522 \\
531\end{array}$ & $\begin{array}{l}L \\
L \\
L \\
N \\
N\end{array}$ & $\begin{array}{l}\mathrm{L} \\
\mathrm{L} \\
\mathrm{L} \\
\mathrm{L} \\
\mathrm{L}\end{array}$ & $\begin{array}{r}20 \\
15 \\
L \\
15 \\
15\end{array}$ & $\begin{array}{l}\mathrm{N} \\
\mathrm{L} \\
\mathrm{L} \\
\mathrm{N} \\
\mathrm{N}\end{array}$ & $\begin{array}{r}150 \\
150 \\
N \\
100 \\
500\end{array}$ & $\begin{array}{r}15 \\
50 \\
30 \\
10 \\
\mathrm{~L}\end{array}$ & $\begin{array}{c}10 \\
N \\
N \\
N \\
N\end{array}$ & $\begin{array}{l}70 \\
50 \\
70 \\
30 \\
70\end{array}$ & $\begin{array}{l}26-40-107 \\
26-40-107 \\
35-41-107 \\
35-41-107 \\
23-37-106\end{array}$ & $\begin{array}{l}\text { In foult zone. } \\
\text { Do. } \\
\text { Near fault zone. } \\
\text { Do. } \\
\text { Dike. }\end{array}$ \\
\hline $\begin{array}{l}537 \\
549 \\
805 \\
807 \\
808\end{array}$ & $\begin{array}{l}\mathrm{L} \\
\mathrm{N} \\
\mathrm{N} \\
\mathrm{N} \\
\mathrm{L}\end{array}$ & $\begin{array}{r}70 \\
7 \\
L \\
L \\
L\end{array}$ & $\begin{array}{r}\mathrm{L} \\
20 \\
15 \\
15 \\
\mathrm{~L}\end{array}$ & $\begin{array}{l}10 \\
N \\
N \\
N \\
N\end{array}$ & $\begin{array}{r}N \\
150 \\
N \\
100 \\
N\end{array}$ & $\begin{array}{r}70 \\
10 \\
10 \\
L \\
10\end{array}$ & $\begin{array}{r}10 \\
30 \\
\mathrm{~L} \\
15 \\
\mathrm{~N}\end{array}$ & $\begin{array}{r}70 \\
100 \\
70 \\
50 \\
100\end{array}$ & $\begin{array}{r}7-37-105 \\
2-39-108 \\
33-41-107 \\
3-40-107 \\
34-41-107\end{array}$ & $\begin{array}{l}\text { Small body. } \\
\text { Porph phase. }\end{array}$ \\
\hline $\begin{array}{l}854 \\
864 \\
880 \\
891 \\
897\end{array}$ & $\begin{array}{l}\mathrm{L} \\
\mathrm{N} \\
\mathrm{L} \\
\mathrm{L}\end{array}$ & $\begin{array}{r}7 \\
\mathrm{~L} \\
10 \\
7 \\
7\end{array}$ & $\begin{array}{l}15 \\
50 \\
50 \\
10 \\
15\end{array}$ & $\begin{array}{c}N \\
N \\
10 \\
N \\
N\end{array}$ & $\begin{array}{l}300 \\
300 \\
500 \\
500 \\
500\end{array}$ & $\begin{array}{l}L \\
L \\
30 \\
30 \\
10\end{array}$ & $\begin{array}{l}N \\
N \\
10 \\
15 \\
15\end{array}$ & $\begin{array}{l}50 \\
70 \\
70 \\
10 \\
10\end{array}$ & $\begin{array}{r}15-36-106 \\
9-36-106 \\
33-36-106 \\
5-35-106 \\
7-35-106\end{array}$ & $\begin{array}{l}\text { Dike. } \\
\text { Do. } \\
\text { Near shear zone. } \\
\text { Porph granite. } \\
\text { Do. }\end{array}$ \\
\hline 898 & \llcorner & 10 & 15 & 5 & 500 & 20 & 10 & 30 & $8-35-106$ & Do. \\
\hline \multicolumn{11}{|c|}{ Pegmatite and aplite samples } \\
\hline $\begin{array}{l}12 \\
14 \\
18 \\
27 \\
29\end{array}$ & $\begin{array}{r}\mathrm{L} \\
100 \\
N \\
L\end{array}$ & $\begin{array}{r}3 \\
15 \\
2 \\
3 \\
7\end{array}$ & $\begin{array}{l}30 \\
15 \\
30 \\
30 \\
L\end{array}$ & $\begin{array}{c}\mathrm{N} \\
\mathrm{L} \\
15 \\
\mathrm{~N} \\
\mathrm{~L}\end{array}$ & $\begin{array}{r}N \\
150 \\
N \\
N \\
100\end{array}$ & $\begin{array}{l}L \\
L \\
L \\
30\end{array}$ & $\begin{array}{r}50 \\
N \\
20 \\
10 \\
N\end{array}$ & $\begin{array}{r}30 \\
30 \\
N \\
15 \\
N\end{array}$ & $\begin{array}{l}20-40-106 \\
17-37-106 \\
16-37-106 \\
34-38-106 \\
27-38-106\end{array}$ & $\begin{array}{l}\text { Pegmat ite. } \\
\text { Do. } \\
\text { Do. } \\
\text { Do. } \\
\text { Do. }\end{array}$ \\
\hline $\begin{array}{l}33 \\
50 \\
58 \\
62 \\
77\end{array}$ & $\begin{array}{r}\mathrm{L} \\
\mathrm{N} \\
15 \\
10 \\
\mathrm{~N}\end{array}$ & $\begin{array}{r}2 \\
2 \\
L \\
15 \\
7\end{array}$ & $\begin{array}{r}70 \\
20 \\
70 \\
50 \\
1\end{array}$ & $\begin{array}{l}L \\
N \\
N \\
L \\
N\end{array}$ & $\begin{array}{r}L \\
N \\
100 \\
100 \\
150\end{array}$ & $\begin{array}{c}L \\
L \\
10 \\
L \\
L\end{array}$ & $\begin{array}{r}20 \\
N \\
15 \\
15 \\
15\end{array}$ & $\begin{array}{r}100 \\
L \\
50 \\
30 \\
N\end{array}$ & $\begin{array}{l}13-38-106 \\
3039-106 \\
32-39-106 \\
28-39-106 \\
32-39-106\end{array}$ & $\begin{array}{l}\text { Aplite. } \\
\text { Pegmatite. } \\
\text { Do. } \\
\text { Aplite. } \\
\text { Pegmatice. }\end{array}$ \\
\hline $\begin{array}{l}81 \\
105 \\
107 \\
113 \\
120\end{array}$ & $\begin{array}{c}10 \\
10 \\
N \\
L \\
N\end{array}$ & $\begin{array}{r}2 \\
7 \\
2 \\
15 \\
5\end{array}$ & $\begin{array}{r}50 \\
30 \\
L \\
15 \\
30\end{array}$ & $\begin{array}{l}\mathrm{L} \\
\mathrm{L} \\
\mathrm{N} \\
5 \\
\mathrm{~N}\end{array}$ & $\begin{array}{r}N \\
200 \\
N \\
N \\
L\end{array}$ & $\begin{array}{l}L \\
L \\
L \\
L \\
L\end{array}$ & $\begin{array}{r}15 \\
10 \\
N \\
15 \\
10\end{array}$ & $\begin{array}{r}15 \\
100 \\
N \\
20 \\
30\end{array}$ & $\begin{array}{r}15-39-107 \\
27-38-106 \\
26-38-106 \\
14-38-106 \\
7-38-106\end{array}$ & $\begin{array}{l}\text { Do. } \\
\text { Do. } \\
\text { Do. } \\
\text { Do. } \\
\text { Do. }\end{array}$ \\
\hline $\begin{array}{l}123 \\
134 \\
135 \\
154 \\
159\end{array}$ & $\begin{array}{l}\mathrm{L} \\
\mathrm{L} \\
\mathrm{IS} \\
\mathrm{N} \\
\mathrm{L}\end{array}$ & $\begin{array}{r}30 \\
5 \\
3 \\
2 \\
L\end{array}$ & $\begin{array}{r}15 \\
30 \\
50 \\
70 \\
\mathrm{~N}\end{array}$ & $\begin{array}{l}7 \\
N \\
L \\
N \\
N\end{array}$ & $\begin{array}{r}L \\
150 \\
200 \\
100 \\
N\end{array}$ & $\begin{array}{r}30 \\
L \\
L \\
L \\
L\end{array}$ & $\begin{array}{l}20 \\
15 \\
20 \\
N \\
L\end{array}$ & $\begin{array}{r}150 \\
N \\
70 \\
N \\
70\end{array}$ & $\begin{array}{r}14-38-107 \\
17-39-106 \\
16-39-106 \\
3-38-106 \\
19-39-106\end{array}$ & $\begin{array}{l}\text { Do. } \\
\text { Do. } \\
\text { Do. } \\
\text { Do. } \\
\text { Do. }\end{array}$ \\
\hline $\begin{array}{l}176 \\
188 \\
189 \\
412 \\
421\end{array}$ & $\begin{array}{c}\mathrm{L} \\
\mathrm{N} \\
\mathrm{L} \\
70 \\
20\end{array}$ & $\begin{array}{l}\mathrm{L} \\
\mathrm{L} \\
5 \\
2 \\
\mathrm{~L}\end{array}$ & $\begin{array}{r}30 \\
L \\
10 \\
L \\
15\end{array}$ & $\begin{array}{c}\mathrm{N} \\
\mathrm{L} \\
70 \\
\mathrm{~L}\end{array}$ & $\begin{array}{r}150 \\
N \\
100 \\
N \\
N\end{array}$ & $\begin{array}{l}10 \\
10 \\
30 \\
L \\
L\end{array}$ & $\begin{array}{l}10 \\
10 \\
15 \\
N \\
L\end{array}$ & $\begin{array}{r}70 \\
70 \\
N \\
N \\
20\end{array}$ & $\begin{array}{r}21-40-106 \\
35-39-107 \\
35-39-107 \\
9-40-107 \\
21-39-107\end{array}$ & $\begin{array}{l}\text { D. } \\
\text { D. } \\
\text { Do. } \\
\text { Do. } \\
\text { Do. }\end{array}$ \\
\hline $\begin{array}{l}423 \\
457 \\
458 \\
469 \\
471\end{array}$ & $\begin{array}{l}\mathrm{L} \\
\mathrm{N} \\
15 \\
30 \\
50\end{array}$ & $\begin{array}{l}3 \\
5 \\
L \\
L \\
L\end{array}$ & $\begin{array}{r}50 \\
70 \\
100 \\
15 \\
15\end{array}$ & $\begin{array}{c}N \\
N \\
L \\
N \\
15\end{array}$ & $\begin{array}{r}\mathrm{L} \\
150 \\
\mathrm{~N} \\
\mathrm{~N} \\
\mathrm{~N}\end{array}$ & $\begin{array}{r}15 \\
L \\
15 \\
L \\
L\end{array}$ & $\begin{array}{r}15 \\
N \\
15 \\
15 \\
30\end{array}$ & $\begin{array}{r}100 \\
N \\
50 \\
30 \\
N\end{array}$ & $\begin{array}{l}35-39-107 \\
35-40-107 \\
21-40-107 \\
11-40-108 \\
34-41-108\end{array}$ & $\begin{array}{l}\text { Do. } \\
\text { Do. } \\
\text { Do. } \\
\text { Do. } \\
\text { Do. }\end{array}$ \\
\hline
\end{tabular}


TABLE 6.-Analyses of felsic rock samples from the

\begin{tabular}{|c|c|c|c|c|c|c|c|c|c|c|c|c|}
\hline \multirow[b]{2}{*}{ Sample } & \multicolumn{12}{|c|}{ Semiquant itative spectrographic analyses } \\
\hline & $\begin{array}{l}\mathrm{Fe} \\
(.05)\end{array}$ & $\begin{array}{c}\mathrm{Mg} \\
(.02)\end{array}$ & $\begin{array}{c}\mathrm{Ca} \\
(.05)\end{array}$ & $\begin{array}{c}\mathrm{Ti} \\
(.002) \\
\end{array}$ & $\begin{array}{c}M n \\
(10)\end{array}$ & $\begin{array}{c}8 \\
(10)\end{array}$ & $\begin{array}{r}8 \mathbf{B a} \\
-(20) \\
\end{array}$ & $\begin{array}{l}\mathrm{Be} \\
\text { (1) }\end{array}$ & $\begin{array}{l}\mathrm{Co} \\
(5)\end{array}$ & $\begin{array}{l}\mathrm{Cr} \\
(5) \\
\end{array}$ & $\begin{array}{l}\mathrm{Cu} \\
(5) \\
\end{array}$ & $\begin{array}{r}1 a \\
(20) \\
\end{array}$ \\
\hline \multicolumn{13}{|c|}{ Pegmatite and aplite samples - Cont inued } \\
\hline $\begin{array}{l}474 \\
523 \\
525 \\
527 \\
532 \quad 5\end{array}$ & $\begin{array}{l}0.07 \\
1.5 \\
.05 \\
.7 \\
1.5\end{array}$ & $\begin{array}{l}0.05 \\
.5 \\
.03 \\
.07 \\
.15\end{array}$ & $\begin{array}{l}0.05 \\
.3 \\
.2 \\
.3 \\
L^{.3}\end{array}$ & $\begin{array}{l}\mathrm{t} \\
0.02 \\
.007 \\
.007 \\
.03\end{array}$ & $\begin{array}{r}70 \\
70 \\
15 \\
1,500 \\
100\end{array}$ & $\begin{array}{l}\mathbf{N} \\
\mathbf{N} \\
\mathbf{N} \\
\mathbf{N} \\
\mathbf{N}\end{array}$ & $\begin{array}{r}700 \\
20 \\
150 \\
30 \\
300\end{array}$ & $\begin{array}{l}\mathrm{L} \\
3 \\
\mathrm{~L} \\
3 \\
7\end{array}$ & $\begin{array}{l}\mathrm{N} \\
\mathrm{N} \\
\mathrm{N} \\
\mathrm{N} \\
5\end{array}$ & $\begin{array}{l}\mathrm{L} \\
\mathrm{N} \\
\mathrm{N} \\
\mathrm{N} \\
5\end{array}$ & $\begin{array}{r}10 \\
2 \\
7 \\
7 \\
10\end{array}$ & $\begin{array}{l}\mathbf{N} \\
\mathbf{N} \\
\mathbf{N} \\
\mathbf{N} \\
\mathbf{N}\end{array}$ \\
\hline $\begin{array}{l}564 \\
566 \\
804 \\
857 \\
879\end{array}$ & $\begin{array}{r}1.5 \\
15 \\
5\end{array}$ & $3^{. .2}$ & $\begin{array}{l}L^{2} .5 \\
2 \\
1\end{array}$ & $\begin{array}{l}.007 \\
.2 \\
.02 \\
.3 \\
.5\end{array}$ & $\begin{array}{r}70 \\
100 \\
L \\
1,500 \\
200\end{array}$ & $\begin{array}{l}\mathbf{N} \\
\mathbf{N} \\
\mathbf{N} \\
\mathbf{N} \\
\mathbf{N}\end{array}$ & $\begin{array}{r}N \\
700 \\
1,000 \\
150 \\
50\end{array}$ & $\begin{array}{l}\mathrm{N} \\
\mathrm{L} \\
\mathrm{N} \\
\mathrm{N} \\
\mathrm{L}\end{array}$ & $\begin{array}{r}\mathrm{L} \\
10 \\
\mathrm{~N} \\
30 \\
15\end{array}$ & $\begin{array}{r}\mathrm{N} \\
100 \\
\mathrm{~L} \\
150 \\
10\end{array}$ & $\begin{array}{r}15 \\
L \\
15 \\
15 \\
7\end{array}$ & $\begin{array}{r}N \\
100 \\
N \\
N \\
300\end{array}$ \\
\hline $\begin{array}{l}885 \\
895\end{array}$ & $\begin{array}{l}5 \\
5\end{array}$ & ${ }^{3} .7$ & $\begin{array}{l}3 \\
2\end{array}$ & $\begin{array}{l}.07 \\
.5\end{array}$ & $\begin{array}{l}700 \\
300\end{array}$ & N & $\begin{array}{l}150 \\
700\end{array}$ & L & $\begin{array}{l}20 \\
15\end{array}$ & $\begin{array}{r}300 \\
15\end{array}$ & 30 & $\begin{array}{r}30 \\
100\end{array}$ \\
\hline \multicolumn{13}{|c|}{ Gneiss and migmatitic gneiss samples } \\
\hline $\begin{array}{l}37 \\
42 \\
65 \\
67 \\
68\end{array}$ & $\begin{array}{l}1.7 \\
1 \\
2 \\
1\end{array}$ & $\begin{array}{l}0.3 \\
.05 \\
.15 \\
.7 \\
.2\end{array}$ & $\begin{array}{l}0.3 \\
.3 \\
.7 \\
1 \\
1\end{array}$ & $\begin{array}{l}0.1 \\
.03 \\
.07 \\
.1 \\
.07\end{array}$ & $\begin{array}{r}100 \\
50 \\
150 \\
200 \\
70\end{array}$ & $\begin{array}{l}\mathbf{N} \\
\mathbf{N} \\
\mathrm{N} \\
\mathrm{N} \\
\mathrm{N}\end{array}$ & $\begin{array}{r}500 \\
70 \\
700 \\
700 \\
700\end{array}$ & $\begin{array}{l}\text { I } \\
\mathrm{L} \\
\mathrm{L} \\
\mathrm{N} \\
\mathrm{N}\end{array}$ & $\begin{array}{r}5 \\
N \\
N \\
15 \\
L\end{array}$ & $\begin{array}{r}5 \\
N \\
L \\
10 \\
N\end{array}$ & $\begin{array}{r}20 \\
7 \\
7 \\
5 \\
7\end{array}$ & $\begin{array}{r}70 \\
N \\
20 \\
30 \\
20\end{array}$ \\
\hline $\begin{array}{l}71 \\
96 \\
101 \\
103 \\
118\end{array}$ & $\begin{array}{l}2 \\
1.5 \\
1.5 \\
3 \\
3\end{array}$ & $\begin{array}{l}1 \\
.3 \\
2^{.3}\end{array}$ & $\begin{array}{l}1 \\
1.5 \\
.7 \\
1.5 \\
1.5\end{array}$ & $\begin{array}{l}.15 \\
.15 \\
.15 \\
.2 \\
.3\end{array}$ & $\begin{array}{r}150 \\
70 \\
150 \\
300 \\
300\end{array}$ & $\begin{array}{l}\mathbf{N} \\
\mathbf{N} \\
\mathbf{N} \\
\mathbf{N} \\
\mathbf{N}\end{array}$ & $\begin{array}{l}500 \\
300 \\
700 \\
700 \\
300\end{array}$ & $\begin{array}{l}\mathrm{L} \\
\mathrm{L} \\
1.5 \\
1.5 \\
\mathrm{~L}\end{array}$ & $\begin{array}{r}7 \\
N \\
L \\
30 \\
15\end{array}$ & $\begin{array}{r}\mathbf{N} \\
5 \\
\mathbf{N} \\
70 \\
70\end{array}$ & $\begin{array}{r}10 \\
15 \\
\mathrm{~L} \\
10 \\
15\end{array}$ & $\begin{array}{r}20 \\
100 \\
100 \\
L \\
L\end{array}$ \\
\hline $\begin{array}{l}136 \\
140 \\
147 \\
149 \\
151\end{array}$ & $\begin{array}{l}1.5 \\
1.5 \\
1.5 \\
1.5 \\
1.5\end{array}$ & $\begin{array}{r}.3 \\
1.5 \\
.3 \\
.7 \\
.3\end{array}$ & $1^{1.15}$ & $\begin{array}{l}.07 \\
.15 \\
.15 \\
.07 \\
.1\end{array}$ & $\begin{array}{r}100 \\
70 \\
150 \\
100 \\
150\end{array}$ & $\begin{array}{l}N \\
L \\
N \\
L \\
N\end{array}$ & $\begin{array}{l}150 \\
700 \\
700 \\
300 \\
700\end{array}$ & $\begin{array}{l}\mathrm{L} \\
\mathbf{L} \\
\mathbf{N} \\
\mathrm{N} \\
\mathrm{L}\end{array}$ & $\begin{array}{l}7 \\
N \\
7 \\
7 \\
7\end{array}$ & $\begin{array}{r}\mathrm{L} \\
\mathrm{L} \\
\mathrm{N} \\
10 \\
7\end{array}$ & $\begin{array}{r}N \\
15 \\
2 \\
5 \\
7\end{array}$ & $\begin{array}{l}20 \\
30 \\
30 \\
20 \\
30\end{array}$ \\
\hline $\begin{array}{l}152 \\
153 \\
168 \\
184 \\
185\end{array}$ & $\begin{array}{l}3 \\
3^{-7} \\
5 \\
2\end{array}$ & $\begin{array}{r}.7 \\
.2 \\
1.7\end{array}$ & $\begin{array}{r}1.5 \\
.7 \\
1.5 \\
1.5 \\
.2\end{array}$ & $\begin{array}{l}.15 \\
.05 \\
.2 \\
.05 \\
.15\end{array}$ & $\begin{array}{r}500 \\
70 \\
200 \\
700 \\
150\end{array}$ & $\begin{array}{r}\mathrm{N} \\
\mathrm{N} \\
\mathbf{1 0} \\
\mathrm{L} \\
\mathrm{N}\end{array}$ & $\begin{array}{r}500 \\
300 \\
200 \\
20 \\
700\end{array}$ & $\begin{array}{l}1.5 \\
1.5 \\
1 \\
\mathrm{~N} \\
\mathrm{~L}\end{array}$ & $\begin{array}{r}15 \\
N \\
15 \\
L \\
5\end{array}$ & $\begin{array}{r}70 \\
N \\
50 \\
50 \\
15\end{array}$ & $\begin{array}{r}7 \\
7 \\
20 \\
20 \\
20\end{array}$ & $\begin{array}{r}L \\
L \\
30 \\
H \\
30\end{array}$ \\
\hline $\begin{array}{l}192 \\
406 \\
408 \\
410 \\
411\end{array}$ & $\begin{array}{l}3 \\
3 \\
3 \\
1 \\
3\end{array}$ & $\begin{array}{r}.1 \\
.7 \\
1.5 \\
.7 \\
.7\end{array}$ & $\begin{array}{l}3 \\
1.5 \\
2 \\
.7 \\
1.5\end{array}$ & $\begin{array}{l}.07 \\
.2 \\
.2 \\
.1 \\
.15\end{array}$ & $\begin{array}{r}50 \\
300 \\
500 \\
150 \\
200\end{array}$ & $\begin{array}{l}\mathbf{N} \\
\mathbf{N} \\
\mathbf{N} \\
\mathbf{N} \\
\mathbf{N}\end{array}$ & $\begin{array}{r}L \\
200 \\
500 \\
700 \\
700\end{array}$ & $\begin{array}{l}\mathrm{N} \\
1 \\
\mathrm{I} \\
\mathrm{L} \\
\mathrm{L}\end{array}$ & $\begin{array}{r}N \\
15 \\
15 \\
L \\
10\end{array}$ & $\begin{array}{l}L \\
70 \\
70 \\
15 \\
15\end{array}$ & $\begin{array}{r}15 \\
15 \\
15 \\
30 \\
7\end{array}$ & $\begin{array}{r}300 \\
20 \\
L \\
20 \\
50\end{array}$ \\
\hline $\begin{array}{l}425 \\
431 \\
432 \\
451 \\
468\end{array}$ & $\begin{array}{l}3 \\
3 \\
3 \\
2 \\
3\end{array}$ & $\begin{array}{l}.5 \\
.7 \\
.7 \\
.3 \\
1.3\end{array}$ & $\begin{array}{l}1 \\
1.5 \\
1.5 \\
.7\end{array}$ & $\begin{array}{l}.3 \\
.3 \\
.3 \\
.1 \\
.7\end{array}$ & $\begin{array}{l}150 \\
300 \\
300 \\
150 \\
500\end{array}$ & $\begin{array}{l}\mathbf{N} \\
\mathbf{N} \\
\mathbf{N} \\
\mathbf{N} \\
\mathbf{N}\end{array}$ & $\begin{array}{r}1,500 \\
300 \\
300 \\
700 \\
700\end{array}$ & $\begin{array}{r}\mathrm{L} \\
1.5 \\
1 \\
1 \\
1.5\end{array}$ & $\begin{array}{r}7 \\
15 \\
15 \\
5 \\
15\end{array}$ & $\begin{array}{l}\mathrm{L} \\
15 \\
15 \\
10 \\
30\end{array}$ & $\begin{array}{l}50 \\
20 \\
30 \\
10 \\
20\end{array}$ & $\begin{array}{r}100 \\
100 \\
100 \\
100 \\
50\end{array}$ \\
\hline $\begin{array}{l}492 \\
499 \\
500 \\
503 \\
504\end{array}$ & $\begin{array}{r}2 \\
1 \\
1 \\
3 \\
10\end{array}$ & $\begin{array}{l}.7 \\
.2 \\
.3 \\
3\end{array}$ & $\begin{array}{l}1 \\
1 \\
2 \\
1.5 \\
3\end{array}$ & $\begin{array}{l}.2 \\
.07 \\
.15 \\
.2 \\
.3\end{array}$ & $\begin{array}{r}200 \\
100 \\
70 \\
200 \\
1,000\end{array}$ & $\begin{array}{l}\mathbf{N} \\
\mathbf{N} \\
\mathbf{N} \\
\mathbf{N} \\
\mathbf{N}\end{array}$ & $\begin{array}{l}200 \\
700 \\
300 \\
150 \\
100\end{array}$ & $\begin{array}{l}\mathbf{1} \\
\mathbf{N} \\
\mathrm{L} \\
\mathrm{N} \\
\mathrm{N}\end{array}$ & $\begin{array}{r}7 \\
\mathrm{~L} \\
7 \\
10 \\
70\end{array}$ & $\begin{array}{r}10 \\
N \\
N \\
50 \\
300\end{array}$ & $\begin{array}{r}15 \\
5 \\
10 \\
15 \\
150\end{array}$ & $\begin{array}{r}\mathrm{L} \\
N \\
\mathrm{~N} \\
50 \\
\mathrm{~N}\end{array}$ \\
\hline $\begin{array}{l}505 \\
512 \\
513 \\
528 \\
530\end{array}$ & $\begin{array}{l}3 \\
5 \\
3 \\
7^{.7}\end{array}$ & $\begin{array}{l}2^{.5} \\
.15 \\
1.5\end{array}$ & $\begin{array}{l}1 \\
5 \\
2^{.3}\end{array}$ & $\begin{array}{l}.3 \\
.5 \\
.3 \\
.07 \\
.7\end{array}$ & $\begin{array}{r}500 \\
300 \\
150 \\
70 \\
500\end{array}$ & $\begin{array}{l}\mathbf{N} \\
\mathbf{N} \\
\mathbf{N} \\
\mathbf{N} \\
\mathbf{N}\end{array}$ & $\begin{array}{r}700 \\
500 \\
i, 000 \\
700 \\
>5,000\end{array}$ & $\begin{array}{l}\mathrm{L} \\
1 \\
1.5 \\
\mathrm{~N} \\
1\end{array}$ & $\begin{array}{r}\mathrm{L} \\
15 \\
15 \\
5 \\
20\end{array}$ & $\begin{array}{r}7 \\
30 \\
50 \\
N \\
30\end{array}$ & $\begin{array}{r}50 \\
20 \\
15 \\
1 \\
15\end{array}$ & $\begin{array}{r}30 \\
70 \\
30 \\
30 \\
200\end{array}$ \\
\hline $\begin{array}{l}535 \\
540 \\
541 \\
543 \\
544\end{array}$ & $\begin{array}{l}10 \\
1.5 \\
5 \\
1 \\
5\end{array}$ & $\begin{array}{l}1.5 \\
1.3 \\
.1 \\
1.5\end{array}$ & $3^{1.3}$ & $\begin{array}{l}.3 \\
.2 \\
.3 \\
.05 \\
.3\end{array}$ & $\begin{array}{r}1,500 \\
150 \\
500 \\
50 \\
700\end{array}$ & $\begin{array}{l}\mathbf{N} \\
\mathbf{N} \\
\mathbf{N} \\
\mathbf{N} \\
\mathbf{N}\end{array}$ & $\begin{array}{r}70 \\
300 \\
300 \\
300 \\
200\end{array}$ & $\begin{array}{l}\mathrm{L} \\
\mathbf{N} \\
\mathbf{N} \\
\mathbf{N} \\
\mathbf{N}\end{array}$ & $\begin{array}{r}15 \\
5 \\
20 \\
N \\
70\end{array}$ & $\begin{array}{r}700 \\
\mathrm{~L} \\
200 \\
\mathrm{~N} \\
150\end{array}$ & $\begin{array}{l}15 \\
20 \\
10 \\
15 \\
70\end{array}$ & $\begin{array}{c}\mathrm{L} \\
N \\
50 \\
\mathrm{~L} \\
N\end{array}$ \\
\hline
\end{tabular}

4) Contains $10 \mathrm{ppm} \mathrm{Sn}$

5) Contains $15 \mathrm{ppm} 5 \mathrm{n}$ 


\begin{tabular}{|c|c|c|c|c|c|c|c|c|c|c|}
\hline \multirow[b]{2}{*}{ Sample } & \multicolumn{8}{|c|}{$\begin{array}{c}\text { Semi quant } j \text { tative spect rographic } \\
\text { analyses--Cont inued } \\
\text { (ppm) }\end{array}$} & \multirow[b]{2}{*}{$\begin{array}{l}\text { Location } \\
\text { Sec-Twp-Rge }\end{array}$} & \multirow[b]{2}{*}{ Remarks } \\
\hline & $\begin{array}{l}\mathrm{Nb} \\
(10) \\
\end{array}$ & $\begin{array}{l}\mathrm{Ni} \\
(5)\end{array}$ & $\begin{array}{l}\mathrm{Pb} \\
(10)\end{array}$ & $\begin{array}{l}\mathbf{s} \bar{c} \\
(5)\end{array}$ & $\begin{array}{c}r \\
(100)\end{array}$ & $\begin{array}{c}v \\
(10)\end{array}$ & $\begin{array}{c}Y \\
(10) \\
\end{array}$ & $\begin{array}{c}\overline{z r} \\
(10)\end{array}$ & & \\
\hline \multicolumn{11}{|c|}{ Pegmatice and apl ite samples--Cont inued } \\
\hline 474 & $\mathbf{N}$ & $\mathrm{L}$ & 100 & $\mathbf{N}$ & L & $\mathbf{L}$ & $\mathrm{N}$ & $\mathrm{N}$ & $24-40-108$ & Pegmatite. \\
\hline 523 & 20 & $\mathrm{~L}$ & 15 & $\mathrm{~L}$ & N & 10 & 10 & 50 & $25-40-108$ & Do. \\
\hline 525 & $\mathrm{~N}$ & L & $i$ & N & $\mathrm{N}$ & l & $\mathrm{N}$ & 10 & $12-37-106$ & Do. \\
\hline 527 & 10 & $\mathrm{~L}$ & 15 & N & N & $\mathrm{L}$ & 70 & 20 & $31-38-105$ & Do. \\
\hline 532 & 50 & 30 & L & 5 & $\mathrm{~N}$ & 20 & $\mathrm{~N}$ & $\mathrm{~N}$ & $13-37-106$ & Pegmatite, Fe st. \\
\hline 564 & $\mathrm{~L}$ & 15 & $\mathrm{~L}$ & $\mathrm{~N}$ & N & 10 & $N$ & N & $30-38-105$ & Pegmatite, chloritic. \\
\hline 566 & $L$ & 30 & 15 & 10 & L & 30 & 30 & 100 & $20-38-105$ & Pegmatite. \\
\hline 804 & $\mathrm{~N}$ & L & 20 & N & N & L & $\mathrm{N}$ & N & $23-41-108$ & Do. \\
\hline 857 & 10 & 50 & 10 & 30 & $\mathrm{~L}$ & 150 & 15 & 30 & $20-37-105$ & Amphibole-rich pegmatite. \\
\hline & $\mathrm{L}$ & 15 & 30 & 10 & 100 & 50 & 30 & 300 & $32-36-106$ & Aplite, dark gray. \\
\hline $\begin{array}{l}885 \\
895\end{array}$ & 10 & $\begin{array}{r}100 \\
15\end{array}$ & $\begin{array}{l}30 \\
10\end{array}$ & $\begin{array}{l}15 \\
15\end{array}$ & $\begin{array}{l}150 \\
200\end{array}$ & $\begin{array}{l}70 \\
70\end{array}$ & $\begin{array}{l}10 \\
70\end{array}$ & $\begin{array}{r}N \\
300\end{array}$ & $\begin{array}{l}30-37-106 \\
20-36-106\end{array}$ & $\begin{array}{l}\text { Amphibole-rich pegmatite. } \\
\text { Aplite, dark gray. }\end{array}$ \\
\hline \multicolumn{11}{|c|}{ Gneiss and migmatitic gneiss samples } \\
\hline 37 & $\mathbf{L}$ & 3 & 30 & $\mathbf{L}$ & N & $L$ & 10 & 150 & $7-38-105$ & Migmatitic. \\
\hline 42 & $\bar{N}$ & 3 & 20 & $\mathbf{N}$ & $\mathrm{N}$ & L & 30 & 30 & $7-38-106$ & Do. \\
\hline 65 & $\mathrm{~L}$ & 2 & 10 & $L$ & L & i. & L & 100 & $7-38-105$ & \\
\hline 67 & $\mathrm{~N}$ & 15 & 15 & 7 & 150 & 50 & 10 & 100 & $8-38-105$ & \\
\hline 68 & $\ddot{L}$ & 3 & 15 & N & 300 & 20 & N & 100 & $9-38-105$ & \\
\hline 71 & 15 & $\mathrm{~L}$ & $\mathrm{~N}$ & 7 & $\mathbf{L}$ & 15 & 15 & 300 & $14-39-106$ & \\
\hline 96 & L & 5 & 15 & 5 & 100 & 20 & 50 & 150 & $3-39-107$ & Migmatitic. \\
\hline 101 & $\mathrm{~L}$ & 2 & 15 & 5 & 150 & 20 & 15 & 150 & $8-37-106$ & \\
\hline 103 & 15 & 70 & 15 & 15 & 100 & 100 & 30 & 30 & $33-38-106$ & \\
\hline 118 & $\mathrm{~L}$ & 20 & 15 & 10 & 150 & 70 & 10 & 150 & $28-40-106$ & Migmatitic. \\
\hline 136 & $\mathbf{N}$ & 7 & $\mathbf{N}$ & L & N & 20 & $\mathbf{N}$ & 70 & $12-38-106$ & \\
\hline 140 & 15 & N & N & 7 & $\mathrm{~N}$ & L & 100 & 300 & $10-39-106$ & \\
\hline 147 & N & 3 & 30 & 5 & 100 & 20 & 15 & 100 & $19-39=105$ & \\
\hline 149 & L & 15 & 10 & $\hat{L}$ & L & 15 & $\mathrm{~N}$ & 50 & $24-39-106$ & \\
\hline 151 & $\bar{L}$ & 7 & 15 & $\underline{L}$ & 300 & 10 & 10 & 150 & $27-39-106$ & \\
\hline 152 & $L$ & 20 & 15 & 15 & 100 & 100 & 30 & 50 & $27-39-106$ & \\
\hline 153 & L & 2 & 30 & N & 100 & L & 10 & 30 & $34-39-106$ & \\
\hline 168 & $\bar{L}$ & 20 & L & 7 & 150 & 70 & 30 & 70 & $10-39-107$ & Migmatitic. \\
\hline 184 & L & 5 & L & 7 & N & 30 & 30 & 150 & $8-40-107$ & \\
\hline 185 & $\mathrm{~L}$ & 15 & 15 & 5 & $\ddot{L}$ & 15 & 10 & 150 & $5-40-107$ & \\
\hline 192 & L & 3 & L & 7 & 500 & 70 & 30 & 70 & $15-38-107$ & Fractured. \\
\hline 406 & 10 & 20 & 15 & 7 & 100 & 70 & L & 150 & $29-40-106$ & \\
\hline 408 & $L$ & 30 & L & 10 & 100 & 70 & 30 & 150 & $21-40-107$ & \\
\hline $\begin{array}{l}410 \\
411\end{array}$ & N & 15 & 15 & $\mathrm{~L}$ & 100 & 20 & N & 30 & $21-40-107$ & Granite(?) \\
\hline & & & & & & & & & & \\
\hline 425 & $L$ & 5 & 20 & 5 & 500 & 50 & 20 & 200 & $35-39-107$ & Contains garnet. \\
\hline $\begin{array}{l}431 \\
432\end{array}$ & 15 & 15 & $\mathrm{~L}$ & 15 & 100 & 30 & 70 & 150 & $35-38-107$ & \\
\hline $\begin{array}{l}432 \\
451\end{array}$ & 10 & 15 & 10 & 10 & 300 & 30 & 30 & 150 & $35-38-107$ & Dark gray. \\
\hline 468 & 30 & 20 & $\begin{array}{l}15 \\
10\end{array}$ & $\begin{array}{r}5 \\
15\end{array}$ & $\begin{array}{l}200 \\
100\end{array}$ & $\begin{array}{r}15 \\
100\end{array}$ & $\begin{array}{r}20 \\
150\end{array}$ & $\begin{array}{l}150 \\
500\end{array}$ & $\begin{array}{l}26-39-106 \\
11-40-108\end{array}$ & \\
\hline 492 & $\mathrm{~L}$ & 7 & N & 5 & 150 & 30 & l & 70 & $13-41-108$ & Migmatitic. \\
\hline 499 & $\mathrm{~N}$ & 5 & 10 & N & 300 & 10 & $\mathrm{~N}$ & 30 & $23-41-108$ & D. \\
\hline 500 & $\mathrm{~N}$ & 15 & 10 & $\hat{L}$ & 500 & 30 & $\mathrm{~N}$ & L & $23-41-108$ & Do. \\
\hline 503 & L & 7 & $i$ & 10 & 200 & 70 & 15 & 70 & $21-39-105$ & \\
\hline 504 & L & 70 & N & 20 & ᄂ & 150 & 15 & 50 & $20-39-105$ & Fe st. \\
\hline 505 & $\mathrm{~L}$ & $\mathbf{N}$ & 10 & 7 & 100 & 30 & 10 & 150 & $20-39-105$ & \\
\hline 512 & 20 & 15 & 10 & 15 & L & 100 & 150 & 300 & $4-39-107$ & Migmatitic. \\
\hline 513 & $\mathrm{~L}$ & 10 & 10 & 7 & 700 & 50 & 10 & 100 & $6-39-107$ & \\
\hline 528 & N & L & 20 & N & L & 15 & N & 30 & $24-37-106$ & \\
\hline 530 & $\mathbf{L}$ & 20 & 30 & 15 & 1,500 & 70 & 50 & 500 & $23-37-106$ & Fe st. \\
\hline 535 & $\mathbf{L}$ & 30 & N & 30 & N & 100 & 20 & 50 & $7-37-105$ & Fe st. \\
\hline 540 & $\mathrm{~N}$ & 5 & 10 & L & 300 & 20 & $N$ & 100 & $4-37-105$ & \\
\hline 541 & $\ddot{L}$ & 70 & 20 & 15 & 150 & 100 & $\mathrm{~N}$ & 100 & $33-38-105$ & \\
\hline 543 & N & $\mathrm{L}$ & 10 & N & $\mathrm{N}$ & 15 & $\mathrm{~N}$ & 50 & $5-37-105$ & \\
\hline 544 & $\ddot{L}$ & 70 & 10 & 15 & 200 & 150 & $\mathrm{~L}$ & $\mathrm{~L}$ & $5-37-105$ & \\
\hline
\end{tabular}

6) Contains $10 \mathrm{ppm}$ Mo. 
TABLE 6-Analyses of felsic rock samples from the

Semiquantitative spectrographic analyses

\begin{tabular}{|c|c|c|c|c|c|c|c|c|c|c|c|c|}
\hline & & & & & & (ppr & & & & & & \\
\hline Sample & $\begin{array}{c}\mathrm{Fe} \\
(.05)\end{array}$ & $\begin{array}{c}\mathrm{Mg} \\
(.02)\end{array}$ & $\begin{array}{c}\mathrm{Ca} \\
(.05)\end{array}$ & $\begin{array}{c}\mathrm{Ti} \\
(.002)\end{array}$ & $\begin{array}{c}M n \\
(10)\end{array}$ & $\begin{array}{c}\mathrm{B} \\
(10)\end{array}$ & $\begin{array}{c}\text { Ba } \\
(20)\end{array}$ & $\begin{array}{l}\text { 日e } \\
\text { (1) }\end{array}$ & $\begin{array}{l}\text { Co } \\
\text { (5) }\end{array}$ & $\begin{array}{l}\mathbf{C r} \\
(5)\end{array}$ & $\begin{array}{l}\text { Cu } \\
\text { (5) }\end{array}$ & $\begin{array}{c}\mathrm{La} \\
(20)\end{array}$ \\
\hline
\end{tabular}

Gneiss and migmatitic gneiss samples--Continued

\begin{tabular}{|c|c|c|c|c|c|c|c|c|c|c|c|}
\hline $\begin{array}{l}545 \\
548 \\
551 \\
552 \\
553\end{array}$ & $\begin{array}{l}0.7 \\
.3 \\
2 \\
3\end{array}$ & $\begin{array}{c}0.15 \\
.1 \\
.7 \\
.7\end{array}$ & $\begin{array}{l}1 \\
.2 \\
1.5 \\
2 \\
2\end{array}$ & $\begin{array}{c}0.07 \\
.02 \\
.3 \\
.15 \\
.2\end{array}$ & $\begin{array}{r}100 \\
50 \\
1,000 \\
200 \\
500\end{array}$ & $\begin{array}{l}\mathbf{N} \\
\mathbf{N} \\
\mathbf{N} \\
\mathbf{N} \\
\mathbf{N}\end{array}$ & $\begin{array}{r}15 \\
1,000 \\
300 \\
500 \\
700\end{array}$ & $\begin{array}{l}\mathrm{L} \\
\mathrm{L} \\
\mathrm{N} \\
\mathrm{N} \\
\mathrm{N}\end{array}$ & $\begin{array}{r}\mathrm{N} \\
\mathrm{N} \\
15 \\
5 \\
7\end{array}$ & $\begin{array}{r}5 \\
\mathrm{~L} \\
500 \\
15 \\
10\end{array}$ & $\begin{array}{r}20 \\
5 \\
10 \\
7 \\
15\end{array}$ \\
\hline
\end{tabular}

\section{Gneiss samples}

\begin{tabular}{|c|c|c|c|c|c|c|c|c|c|c|c|c|}
\hline $\begin{array}{l}554 \\
555 \\
556 \\
558 \\
567\end{array}$ & $\begin{array}{l}5 \\
2 \\
5 \\
1.5 \\
.7\end{array}$ & $\begin{array}{r}1.5 \\
.3 \\
1.5 \\
.7 \\
.2\end{array}$ & $\begin{array}{l}2 \\
1.5 \\
3 \\
1.5 \\
1\end{array}$ & $\begin{array}{l}0.3 \\
.15 \\
.3 \\
.1 \\
.07\end{array}$ & $\begin{array}{l}500 \\
300 \\
700 \\
150 \\
100\end{array}$ & $\begin{array}{l}\mathbf{N} \\
\mathbf{N} \\
\mathbf{N} \\
\mathrm{N} \\
\mathrm{N}\end{array}$ & $\begin{array}{r}700 \\
1,500 \\
300 \\
300 \\
500\end{array}$ & $\begin{array}{l}\text { N } \\
\text { L } \\
N \\
\text { L } \\
\text { L }\end{array}$ & $\begin{array}{r}10 \\
N \\
7 \\
5 \\
N\end{array}$ & $\begin{array}{r}20 \\
L \\
15 \\
L \\
L\end{array}$ & $\begin{array}{r}20 \\
20 \\
30 \\
20 \\
5\end{array}$ & $\begin{array}{r}20 \\
\mathrm{~L} \\
30 \\
70 \\
\mathrm{~N}\end{array}$ \\
\hline $\begin{array}{l}568 \\
570 \\
801 \\
802 \\
803\end{array}$ & $\begin{array}{l}5 \\
1.5 \\
.2 \\
1 \\
2\end{array}$ & $\begin{array}{l}3 \\
.5 \\
.1 \\
.3 \\
.3\end{array}$ & $\begin{array}{r}5 \\
.2 \\
1.5 \\
.7 \\
.7\end{array}$ & $\begin{array}{l}.2 \\
.1 \\
.03 \\
.07 \\
.15\end{array}$ & $\begin{array}{r}700 \\
100 \\
30 \\
50 \\
150\end{array}$ & $\begin{array}{l}\mathrm{N} \\
\mathrm{N} \\
\mathrm{N} \\
\mathrm{N} \\
\mathrm{N}\end{array}$ & $\begin{array}{r}150 \\
1,000 \\
300 \\
3,000 \\
2,000\end{array}$ & $\begin{array}{l}\mathrm{L} \\
\mathrm{L} \\
\mathrm{I} \\
\mathrm{L}\end{array}$ & $\begin{array}{r}20 \\
5 \\
5 \\
5 \\
10\end{array}$ & $\begin{array}{r}300 \\
7 \\
7 \\
L \\
50\end{array}$ & $\begin{array}{r}30 \\
5 \\
7 \\
5 \\
7\end{array}$ & $\begin{array}{r}30 \\
100 \\
N \\
N \\
50\end{array}$ \\
\hline $\begin{array}{l}813 \\
815 \\
816 \\
817 \\
819\end{array} 6$ & $\begin{array}{r}2 \\
2 \\
3 \\
10 \\
3\end{array}$ & $\begin{array}{l}.3 \\
.3 \\
.5 \\
.7 \\
1\end{array}$ & $\begin{array}{l}1.5 \\
1 \\
.2 \\
.7\end{array}$ & $\begin{array}{l}.3 \\
.15 \\
.15 \\
.02 \\
.2\end{array}$ & $\begin{array}{r}100 \\
150 \\
100 \\
1,000 \\
300\end{array}$ & $\begin{array}{l}\mathbf{N} \\
\mathbf{N} \\
\mathbf{N} \\
\mathbf{N} \\
\mathbf{N}\end{array}$ & $\begin{array}{r}700 \\
2,000 \\
1,500 \\
20 \\
150\end{array}$ & $\begin{array}{l}1 \\
\mathrm{~L} \\
1 \\
\mathrm{~L} \\
1\end{array}$ & $\begin{array}{r}5 \\
5 \\
L \\
5 \\
10\end{array}$ & $\begin{array}{r}L \\
L \\
30 \\
50 \\
5\end{array}$ & $\begin{array}{l}15 \\
15 \\
15 \\
50 \\
N\end{array}$ & $\begin{array}{r}20 \\
\mathrm{~L} \\
30 \\
\mathrm{~N} \\
20\end{array}$ \\
\hline $\begin{array}{l}820 \\
831 \\
833 \\
834 \\
836\end{array}$ & $\begin{array}{l}2 \\
5 \\
7 \\
5 \\
1.5\end{array}$ & $\begin{array}{l}2^{.5} \\
.7 \\
.5\end{array}$ & $\begin{array}{l}1.5 \\
3 \\
2 \\
1.5 \\
.5\end{array}$ & $\begin{array}{l}.2 \\
.3 \\
.3 \\
.2 \\
.1\end{array}$ & $\begin{array}{l}200 \\
700 \\
700 \\
500 \\
150\end{array}$ & $\begin{array}{l}N \\
N \\
N \\
N \\
L\end{array}$ & $\begin{array}{r}100 \\
1,000 \\
1,000 \\
700 \\
300\end{array}$ & $\begin{array}{l}\text { I } \\
\text { N } \\
\text { L } \\
\text { L } \\
\text { L }\end{array}$ & $\begin{array}{r}7 \\
20 \\
15 \\
10 \\
\text { L }\end{array}$ & $\begin{array}{r}1 \\
150 \\
1,000 \\
15 \\
20\end{array}$ & $\begin{array}{r}30 \\
5 \\
300 \\
L \\
5\end{array}$ & $\begin{array}{r}30 \\
N \\
20 \\
30 \\
N\end{array}$ \\
\hline $\begin{array}{l}846 \\
847 \\
850 \\
855 \\
856\end{array}$ & $\begin{array}{r}20 \\
5 \\
7 \\
2 \\
5\end{array}$ & $\begin{array}{l}3 \\
1.5 \\
1.5 \\
1^{.5}\end{array}$ & $\begin{array}{l}3^{.3} \\
1.5 \\
1.5\end{array}$ & $\begin{array}{l}.3 \\
.2 \\
.2 \\
.15 \\
.3\end{array}$ & $\begin{array}{r}1,500 \\
700 \\
500 \\
200 \\
500\end{array}$ & $\begin{array}{r}\mathrm{N} \\
\mathrm{N} \\
10 \\
\mathrm{~N} \\
\mathrm{~N}\end{array}$ & $\begin{array}{r}1,000 \\
300 \\
300 \\
1,000 \\
50\end{array}$ & $\begin{array}{l}\mathrm{L} \\
\mathrm{N} \\
\mathrm{L} \\
\mathrm{L} \\
\mathrm{L}\end{array}$ & $\begin{array}{l}15 \\
15 \\
15 \\
10 \\
L\end{array}$ & $\begin{array}{r}700 \\
50 \\
70 \\
5 \\
15\end{array}$ & $\begin{array}{r}70 \\
10 \\
5 \\
5 \\
7\end{array}$ & $\begin{array}{r}\text { N } \\
20 \\
\text { L } \\
50 \\
50\end{array}$ \\
\hline $\begin{array}{l}858 \quad 7 \\
863 \\
883 \\
884 \quad 8 \\
888\end{array}$ & $\begin{array}{r}10 \\
7 \\
3 \\
15 \\
2\end{array}$ & $\begin{array}{l}2 \\
1.5 \\
1.5 \\
5 \\
1\end{array}$ & $\begin{array}{l}2^{.1} \\
1 \\
1 \\
1.5\end{array}$ & $\begin{array}{l}.7 \\
.5 \\
.15 \\
.5 \\
.15\end{array}$ & $\begin{array}{l}300 \\
700 \\
300 \\
300 \\
200\end{array}$ & $\begin{array}{l}\mathbf{N} \\
\mathbf{N} \\
\mathbf{N} \\
\mathbf{N} \\
\mathbf{N}\end{array}$ & $\begin{array}{l}700 \\
700 \\
300 \\
300 \\
700\end{array}$ & $\begin{array}{l}\mathrm{L} \\
1 \\
\mathrm{~L} \\
\mathrm{I} \\
\mathrm{L}\end{array}$ & $\begin{array}{r}20 \\
15 \\
15 \\
100 \\
15\end{array}$ & $\begin{array}{r}1.500 \\
50 \\
70 \\
700 \\
50\end{array}$ & $\begin{array}{r}20 \\
10 \\
20 \\
1,500 \\
7\end{array}$ & $\begin{array}{r}\mathrm{N} \\
30 \\
70 \\
\mathrm{~L} \\
30\end{array}$ \\
\hline 899 & 7 & 5 & .5 & .5 & 500 & N & 50 & N & 15 & 15 & 10 & 100 \\
\hline
\end{tabular}

Mignacite samples

\begin{tabular}{|c|c|c|c|c|c|c|c|c|c|c|c|}
\hline $\begin{array}{l}559 \\
562 \\
563 \\
569 \\
571\end{array}$ & $\begin{array}{l}3 \\
1 \\
5 \\
3 \\
5\end{array}$ & $2^{1.2} .05$ & $\begin{array}{l}1 \\
1 \\
3 \\
2\end{array}$ & $\begin{array}{c}0.15 \\
.1 \\
.3 \\
.2 \\
.2\end{array}$ & $\begin{array}{r}200 \\
70 \\
500 \\
200 \\
300\end{array}$ & $\begin{array}{l}\mathbf{N} \\
\mathbf{N} \\
\mathbf{N} \\
\mathbf{N} \\
\mathbf{N}\end{array}$ & $\begin{array}{r}300 \\
700 \\
30 \\
300 \\
500\end{array}$ & $\begin{array}{l}L \\
N \\
N \\
N \\
L\end{array}$ & $\begin{array}{r}10 \\
N \\
10 \\
N \\
15\end{array}$ & $\begin{array}{l}70 \\
10 \\
70 \\
50 \\
7\end{array}$ & $\begin{array}{r}10 \\
15 \\
15 \\
5 \\
7\end{array}$ \\
\hline $\begin{array}{l}572 \\
573 \\
848 \\
849 \\
852\end{array}$ & $\begin{array}{l}3 \\
3 \\
3 \\
2 \\
3\end{array}$ & $\begin{array}{l}1 \\
1 \\
1 \\
.3 \\
.5\end{array}$ & $\begin{array}{l}2 \\
2 \\
1 \\
1 \\
1.5\end{array}$ & $\begin{array}{l}.15 \\
.3 \\
.2 \\
.15 \\
.2\end{array}$ & $\begin{array}{l}300 \\
300 \\
200 \\
150 \\
300\end{array}$ & $\begin{array}{l}\mathrm{N} \\
\mathrm{N} \\
\mathrm{N} \\
\mathrm{N} \\
\mathrm{L}\end{array}$ & $\begin{array}{r}1,000 \\
1,000 \\
150 \\
500 \\
200\end{array}$ & $\begin{array}{l}\mathrm{L} \\
\mathrm{L} \\
\mathrm{L} \\
\mathrm{L} \\
\mathbf{l}\end{array}$ & $\begin{array}{r}10 \\
15 \\
10 \\
7 \\
10\end{array}$ & $\begin{array}{r}30 \\
20 \\
50 \\
L \\
20\end{array}$ & $\begin{array}{r}7 \\
15 \\
10 \\
7 \\
5\end{array}$ \\
\hline $\begin{array}{l}871 \\
872 \\
873 \\
874 \\
875\end{array}$ & $\begin{array}{l}3 \\
3 \\
3 \\
7 \\
2\end{array}$ & $\begin{array}{l}1 \\
1.5 \\
1.5 \\
3.7 \\
.7\end{array}$ & $\begin{array}{l}1.5 \\
.7 \\
2 \\
3 \\
2\end{array}$ & $\begin{array}{l}.15 \\
.2 \\
.2 \\
.3 \\
.2\end{array}$ & $\begin{array}{r}300 \\
300 \\
500 \\
1,000 \\
300\end{array}$ & $\begin{array}{l}\mathbf{N} \\
\mathbf{N} \\
\mathbf{N} \\
\mathbf{N} \\
\mathbf{N}\end{array}$ & $\begin{array}{r}200 \\
100 \\
1,000 \\
3,000 \\
700\end{array}$ & $\begin{array}{l}L \\
L \\
L \\
N \\
L\end{array}$ & $\begin{array}{l}15 \\
10 \\
15 \\
20 \\
10\end{array}$ & $\begin{array}{r}7 \\
7 \\
\mathrm{~L} \\
70 \\
\mathrm{~L}\end{array}$ & $\begin{array}{r}\mathrm{L} \\
\mathrm{L} \\
15 \\
\mathrm{~L}\end{array}$ \\
\hline
\end{tabular}

7f Contains $50 \mathrm{ppm} \mathrm{Mo.}$

8f Contains $1.5 \mathrm{ppm} \mathrm{Ag.}$ 


\begin{tabular}{|c|c|c|c|c|c|c|c|c|c|c|}
\hline \multirow[b]{2}{*}{ Sample } & \multicolumn{8}{|c|}{$\begin{array}{c}\text { Semiquantitative spectrographic } \\
\text { analyses - - Continued } \\
\text { (ppm) }\end{array}$} & \multirow[b]{2}{*}{$\begin{array}{l}\text { Location } \\
\text { Sec-Twp-Rge }\end{array}$} & \multirow[b]{2}{*}{ Remarks } \\
\hline & $\begin{array}{c}\mathrm{Nb} \\
(10) \\
\end{array}$ & $\begin{array}{l}\mathrm{Ni} \\
(5) \\
\end{array}$ & $\begin{array}{c}\mathrm{Pb} \\
(10)\end{array}$ & $\begin{array}{l}\text { Sc } \\
(5)\end{array}$ & $\begin{array}{c}5 r \\
(100)\end{array}$ & $\begin{array}{c}v \\
(10)\end{array}$ & $\begin{array}{c}Y \\
(10)\end{array}$ & $\begin{array}{l}\mathrm{Zr} \\
(10)\end{array}$ & & \\
\hline \multicolumn{11}{|c|}{ Gneiss and migmatitic gneiss samples--Continued } \\
\hline $\begin{array}{l}545 \\
548 \\
551 \\
552 \\
553\end{array}$ & $\begin{array}{l}\mathrm{N} \\
\mathrm{L} \\
\mathrm{L} \\
\mathrm{N} \\
\mathrm{L}\end{array}$ & $\begin{array}{r}5 \\
7 \\
100 \\
10 \\
10\end{array}$ & $\begin{array}{l}10 \\
20 \\
15 \\
15 \\
30\end{array}$ & $\begin{array}{r}N \\
N \\
15 \\
L \\
7\end{array}$ & $\begin{array}{r}300 \\
100 \\
N \\
300 \\
200\end{array}$ & $\begin{array}{r}L \\
L \\
100 \\
30 \\
30\end{array}$ & $\begin{array}{r}N \\
15 \\
15 \\
N \\
10\end{array}$ & $\begin{array}{r}50 \\
10 \\
150 \\
70 \\
150\end{array}$ & $\begin{array}{l}33-38-105 \\
28-38-105 \\
21-37-106 \\
28-37-106 \\
27-37-106\end{array}$ & \\
\hline \multicolumn{11}{|c|}{ Gneiss samples } \\
\hline $\begin{array}{l}554 \\
555 \\
556 \\
558 \\
567\end{array}$ & $\begin{array}{l}\mathrm{L} \\
\mathrm{N} \\
\mathrm{L} \\
\mathrm{L} \\
\mathrm{N}\end{array}$ & $\begin{array}{r}20 \\
5 \\
15 \\
10 \\
2\end{array}$ & $\begin{array}{l}10 \\
30 \\
10 \\
10 \\
15\end{array}$ & $\begin{array}{r}10 \\
N \\
15 \\
L \\
N\end{array}$ & $\begin{array}{l}150 \\
200 \\
150 \\
200 \\
200\end{array}$ & $\begin{array}{r}100 \\
L \\
100 \\
30 \\
L\end{array}$ & $\begin{array}{l}20 \\
15 \\
15 \\
30 \\
N\end{array}$ & $\begin{array}{r}\mathrm{N} \\
70 \\
20 \\
\mathrm{~N} \\
30\end{array}$ & $\begin{array}{l}3-2-6 \\
3-2-6 \\
15-37-106 \\
22-37-106 \\
34-3-6\end{array}$ & \\
\hline $\begin{array}{l}568 \\
570 \\
801 \\
802 \\
803\end{array}$ & $\begin{array}{l}\mathrm{L} \\
\mathrm{L} \\
\mathrm{N} \\
\mathrm{N} \\
\mathrm{L}\end{array}$ & $\begin{array}{r}100 \\
10 \\
10 \\
10 \\
20\end{array}$ & $\begin{array}{r}20 \\
15 \\
N \\
15 \\
15\end{array}$ & $\begin{array}{c}15 \\
L \\
N \\
L \\
5\end{array}$ & $\begin{array}{l}150 \\
100 \\
300 \\
300 \\
300\end{array}$ & $\begin{array}{l}70 \\
10 \\
10 \\
20 \\
30\end{array}$ & $\begin{array}{r}10 \\
10 \\
N \\
N \\
N\end{array}$ & $\begin{array}{r}10 \\
70 \\
100 \\
30 \\
70\end{array}$ & $\begin{array}{r}5-36-106 \\
29-37-106 \\
25-41-108 \\
26-41-108 \\
27-41-108\end{array}$ & $\begin{array}{l}\text { Migmatitic. } \\
\text { Do. } \\
\text { Do. }\end{array}$ \\
\hline $\begin{array}{l}813 \\
815 \\
816 \\
817 \\
819\end{array}$ & $\begin{array}{l}\mathrm{L} \\
\mathrm{L} \\
\mathrm{N} \\
\mathrm{L} \\
\mathrm{L}\end{array}$ & $\begin{array}{r}5 \\
7 \\
L \\
L \\
50\end{array}$ & $\begin{array}{c}N \\
15 \\
10 \\
N \\
N\end{array}$ & $\begin{array}{r}L \\
5 \\
5 \\
15 \\
10\end{array}$ & $\begin{array}{r}500 \\
500 \\
300 \\
N \\
L\end{array}$ & $\begin{array}{l}10 \\
30 \\
30 \\
70 \\
70\end{array}$ & $\begin{array}{c}N \\
N \\
N \\
70 \\
10\end{array}$ & $\begin{array}{r}300 \\
50 \\
70 \\
100 \\
15\end{array}$ & $\begin{array}{r}19-41-108 \\
10-37-106 \\
1-37-106 \\
1-37-106 \\
36-38-106\end{array}$ & $\begin{array}{c}\text { Fe st. } \\
\text { Do }\end{array}$ \\
\hline $\begin{array}{l}820 \\
831 \\
833 \\
834 \\
836\end{array}$ & $\begin{array}{r}\mathrm{L} \\
10 \\
\mathrm{~L} \\
\mathrm{~L} \\
\mathrm{~N}\end{array}$ & $\begin{array}{l}L \\
30 \\
30 \\
10 \\
15\end{array}$ & $\begin{array}{r}10 \\
20 \\
L \\
20 \\
20\end{array}$ & $\begin{array}{r}5 \\
20 \\
15 \\
7 \\
N\end{array}$ & $\begin{array}{r}\text { N } \\
150 \\
L \\
200 \\
150\end{array}$ & $\begin{array}{r}30 \\
100 \\
100 \\
50 \\
10\end{array}$ & $\begin{array}{r}10 \\
15 \\
N \\
N \\
N\end{array}$ & $\begin{array}{r}200 \\
30 \\
100 \\
150 \\
100\end{array}$ & $\begin{array}{r}26-38-106 \\
5-36-106 \\
5-36-106 \\
31-37-105 \\
29-37-105\end{array}$ & Fe st. \\
\hline $\begin{array}{l}846 \\
847 \\
850 \\
855 \\
856\end{array}$ & $\begin{array}{c}L \\
L \\
L \\
L \\
10\end{array}$ & $\begin{array}{r}100 \\
20 \\
30 \\
7 \\
5\end{array}$ & $\begin{array}{r}10 \\
L \\
L \\
15 \\
20\end{array}$ & $\begin{array}{r}30 \\
15 \\
15 \\
7 \\
15\end{array}$ & $\begin{array}{r}N \\
300 \\
100 \\
300 \\
200\end{array}$ & $\begin{array}{r}150 \\
100 \\
100 \\
30 \\
30\end{array}$ & $\begin{array}{l}70 \\
15 \\
20 \\
10 \\
30\end{array}$ & $\begin{array}{r}100 \\
N \\
50 \\
70 \\
150\end{array}$ & $\begin{array}{l}26-37=106 \\
25-37=106 \\
19-38-105 \\
11-37=106 \\
28-37-105\end{array}$ & $\begin{array}{l}\text { Fe st, biot-rich. } \\
\text { Vague foliation. } \\
\text { Very fine grained. }\end{array}$ \\
\hline $\begin{array}{l}858 \\
863 \\
883 \\
884 \\
888\end{array}$ & $\begin{array}{r}15 \\
\mathrm{~L} \\
\mathrm{~L} \\
10 \\
\mathrm{~L}\end{array}$ & $\begin{array}{r}100 \\
30 \\
30 \\
150 \\
30\end{array}$ & $\begin{array}{l}10 \\
20 \\
30 \\
50 \\
20\end{array}$ & $\begin{array}{r}30 \\
10 \\
10 \\
20 \\
L\end{array}$ & $\begin{array}{r}\mathrm{N} \\
500 \\
\mathrm{~L} \\
\mathrm{~N} \\
200\end{array}$ & $\begin{array}{r}150 \\
100 \\
50 \\
200 \\
30\end{array}$ & $\begin{array}{r}N \\
20 \\
10 \\
L \\
L\end{array}$ & $\begin{array}{l}150 \\
150 \\
150 \\
200 \\
150\end{array}$ & $\begin{array}{r}20-37-105 \\
9-36-106 \\
19-37-106 \\
19-37-106 \\
30-37-106\end{array}$ & $\begin{array}{l}\text { Fest, biot-rich. } \\
\text { Fest, biot-rich. } \\
\text { Microcline augen. }\end{array}$ \\
\hline 899 & 10 & 20 & 10 & 10 & $\mathbf{L}$ & 70 & 20 & 150 & $8-35-106$ & Augen in chlorite. \\
\hline \multicolumn{11}{|c|}{ Migmatite samples } \\
\hline $\begin{array}{l}559 \\
562 \\
563 \\
569 \\
571\end{array}$ & $\begin{array}{l}L \\
N \\
L \\
L \\
L\end{array}$ & $\begin{array}{r}30 \\
7 \\
70 \\
L \\
20\end{array}$ & $\begin{array}{l}15 \\
15 \\
10 \\
20 \\
15\end{array}$ & $\begin{array}{r}10 \\
N \\
10 \\
5 \\
7\end{array}$ & $\begin{array}{r}300 \\
150 \\
L \\
500 \\
500\end{array}$ & $\begin{array}{r}30 \\
L \\
70 \\
70 \\
50\end{array}$ & $\begin{array}{r}20 \\
N \\
15 \\
10 \\
15\end{array}$ & $\begin{array}{r}70 \\
20 \\
70 \\
100 \\
50\end{array}$ & $\begin{array}{r}8-36-106 \\
28-36-106 \\
19-36-106 \\
5-36-106 \\
27-37-106\end{array}$ & $\begin{array}{l}\text { Amph ibolitic. } \\
\text { Epidote-rich. } \\
\text { Amphibolitic. }\end{array}$ \\
\hline $\begin{array}{l}572 \\
573 \\
848 \\
849 \\
852\end{array}$ & $\begin{array}{c}N \\
10 \\
L \\
N \\
L\end{array}$ & $\begin{array}{l}20 \\
15 \\
20 \\
15 \\
15\end{array}$ & $\begin{array}{r}20 \\
20 \\
L \\
20 \\
10\end{array}$ & $\begin{array}{r}7 \\
15 \\
10 \\
N \\
7\end{array}$ & $\begin{array}{r}500 \\
500 \\
150 \\
L \\
300\end{array}$ & $\begin{array}{l}20 \\
70 \\
70 \\
15 \\
30\end{array}$ & $\begin{array}{r}20 \\
50 \\
20 \\
L \\
L\end{array}$ & $\begin{array}{r}70 \\
70 \\
100 \\
150 \\
70\end{array}$ & $\begin{array}{r}23-36-105 \\
23-36-105 \\
6-36-106 \\
34-37-106 \\
32-37-106\end{array}$ & Chloritized. \\
\hline $\begin{array}{l}871 \\
872 \\
873 \\
874 \\
875\end{array}$ & $\begin{array}{l}\mathrm{L} \\
\mathrm{L} \\
\mathrm{L} \\
\mathrm{L} \\
\mathrm{L}\end{array}$ & $\begin{array}{l}7 \\
20 \\
15 \\
30 \\
15\end{array}$ & $\begin{array}{l}15 \\
10 \\
20 \\
20 \\
20\end{array}$ & $\begin{array}{r}5 \\
\mathrm{~L} \\
15 \\
15 \\
\mathrm{~L}\end{array}$ & $\begin{array}{l}300 \\
150 \\
500 \\
700 \\
200\end{array}$ & $\begin{array}{l}50 \\
30 \\
50 \\
70 \\
20\end{array}$ & $\begin{array}{l}N \\
2 \\
15 \\
30 \\
N\end{array}$ & $\begin{array}{r}10 \\
150 \\
70 \\
100 \\
100\end{array}$ & $\begin{array}{c}22-36-106 \\
22-36-106 \\
23-36-106 \\
24-36-106 \\
3-15-6\end{array}$ & $\begin{array}{l}\text { Granitized. } \\
\text { Some epidote. } \\
\text { Mobile phase. }\end{array}$ \\
\hline
\end{tabular}


TABLE 6.-Analyses of felsic rack samples from the

\begin{tabular}{|c|c|c|c|c|c|c|c|c|c|c|c|c|}
\hline \multirow[b]{2}{*}{ Sample } & \multicolumn{12}{|c|}{ Semiquantitative spectrographic analyses } \\
\hline & $\begin{array}{c}\mathrm{Fe} \\
(.05) \\
\end{array}$ & $\begin{array}{c}\mathrm{Mg} \\
(.02) \\
\end{array}$ & $\begin{array}{c}c a \\
(.05) \\
\end{array}$ & $\begin{array}{c}\mathrm{Ti} \\
(.002)\end{array}$ & $\begin{array}{c}M n \\
(10)\end{array}$ & $\begin{array}{r}\text { (pp } \\
\text { B } \\
(10)\end{array}$ & $\begin{array}{c}\text { Ba } \\
(20) \\
\end{array}$ & $\begin{array}{l}\text { Be } \\
\text { (1) }\end{array}$ & $\begin{array}{l}c 0 \\
0.5 \\
(5) \\
\end{array}$ & $\begin{array}{l}c_{0} \\
(5) \\
\end{array}$ & $\begin{array}{ll}c_{0} \\
\text { cu } \\
(5)\end{array}$ & $\begin{array}{l}\text { La } \\
(20) \\
\end{array}$ \\
\hline \multicolumn{13}{|c|}{ Migmatite samples--Cont inued } \\
\hline $\begin{array}{l}876 \\
877 \\
878 \\
882 \\
886\end{array}$ & $\begin{array}{l}1 \\
3 \\
3 \\
3 \\
5\end{array}$ & $\begin{array}{r}0.3 \\
.7 \\
.7 \\
.7 \\
2\end{array}$ & $\begin{array}{l}1.5 \\
1.5 \\
2 \\
1.5 \\
2\end{array}$ & $\begin{array}{c}0.1 \\
.2 \\
.15 \\
.3 \\
.3\end{array}$ & $\begin{array}{r}70 \\
300 \\
200 \\
200 \\
200\end{array}$ & $\begin{array}{l}N \\
N \\
N \\
N \\
N\end{array}$ & $\begin{array}{r}1,000 \\
500 \\
200 \\
70 \\
2,000\end{array}$ & $\begin{array}{l}\mathrm{L} \\
\mathrm{L} \\
\mathrm{L} \\
\mathrm{L}\end{array}$ & $\begin{array}{r}10 \\
10 \\
10 \\
7 \\
10\end{array}$ & $\begin{array}{r}L \\
L \\
L \\
L \\
70\end{array}$ & $\begin{array}{r}7 \\
5 \\
7 \\
5 \\
10\end{array}$ & $\begin{array}{r}70 \\
N \\
N \\
30 \\
150\end{array}$ \\
\hline $\begin{array}{l}889 \\
890 \\
892 \\
893 \\
894\end{array}$ & $\begin{array}{l}1.5 \\
3 \\
.5 \\
1.5 \\
2\end{array}$ & $\begin{array}{r}0.7 \\
1.5 \\
.2 \\
.5 \\
.5\end{array}$ & $\begin{array}{l}1 \\
2 \\
.7 \\
1.5 \\
1.5\end{array}$ & $\begin{array}{r}0.15 \\
.15 \\
.05 \\
.2 \\
.15\end{array}$ & $\begin{array}{r}150 \\
700 \\
70 \\
200 \\
200\end{array}$ & $\begin{array}{l}\text { N } \\
\text { N } \\
\text { N } \\
N \\
N\end{array}$ & $\begin{array}{r}70 \\
70 \\
1,000 \\
700 \\
700\end{array}$ & $\begin{array}{l}N \\
N \\
L \\
L \\
L\end{array}$ & $\begin{array}{r}N \\
5 \\
N \\
10 \\
7\end{array}$ & $\begin{array}{r}\text { N } \\
7 \\
7 \\
7 \\
15\end{array}$ & $\begin{array}{c}10 \\
7 \\
15 \\
20 \\
30\end{array}$ & $\begin{array}{l}N \\
N \\
20 \\
30 \\
20\end{array}$ \\
\hline $\begin{array}{l}896 \\
900 \\
1101 \\
1102 \\
1103\end{array}$ & $\begin{array}{l}3 \\
2 \\
2 \\
3 \\
2\end{array}$ & $\begin{array}{l}.7 \\
.2 \\
.7 \\
.7 \\
.5\end{array}$ & $\begin{array}{l}1.5 \\
.5 \\
1.5 \\
1.5\end{array}$ & $\begin{array}{l}.3 \\
.05 \\
.15 \\
.2 \\
.15\end{array}$ & $\begin{array}{r}200 \\
70 \\
200 \\
300 \\
300\end{array}$ & $\begin{array}{l}\mathrm{N} \\
\mathrm{N} \\
\mathrm{N} \\
\mathrm{N} \\
\mathrm{N}\end{array}$ & $\begin{array}{l}700 \\
700 \\
300 \\
300 \\
700\end{array}$ & $\begin{array}{l}\mathbf{L} \\
\mathbf{L} \\
\mathbf{L} \\
\mathbf{L}\end{array}$ & $\begin{array}{r}10 \\
N \\
L \\
10 \\
10\end{array}$ & $\begin{array}{r}20 \\
N \\
L \\
5 \\
L\end{array}$ & $\begin{array}{r}20 \\
7 \\
\mathrm{~L} \\
5 \\
10\end{array}$ & $\begin{array}{l}30 \\
50 \\
N \\
N \\
\text { L }\end{array}$ \\
\hline $\begin{array}{l}1104 \\
1105 \\
1107 \\
1109 \\
1110\end{array}$ & $\begin{array}{l}2 \\
3 \\
2 \\
2\end{array}$ & $\begin{array}{l}.7 \\
.05 \\
1.5\end{array}$ & $\begin{array}{l}2.3 \\
2.3 \\
1.5\end{array}$ & $\begin{array}{l}.05 \\
.03 \\
.2 \\
.15 \\
.15\end{array}$ & $\begin{array}{r}700 \\
70 \\
300 \\
200 \\
200\end{array}$ & $\begin{array}{l}\text { N } \\
\text { N } \\
\text { N } \\
\text { N } \\
\text { N }\end{array}$ & $\begin{array}{l}700 \\
700 \\
700 \\
200 \\
300\end{array}$ & $\begin{array}{l}\mathrm{L} \\
\mathbf{L} \\
\mathrm{L} \\
\mathrm{L}\end{array}$ & $\begin{array}{r}5 \\
N \\
10 \\
10 \\
10\end{array}$ & $\begin{array}{r}5 \\
L \\
20 \\
20 \\
L\end{array}$ & $\begin{array}{l}7 \\
1 \\
5 \\
5 \\
1\end{array}$ & $\begin{array}{r}100 \\
20 \\
20 \\
30 \\
70\end{array}$ \\
\hline 1111 & 1 & .1 & 1 & .07 & 70 & N & 700 & $\mathrm{~N}$ & 5 & N & L & 20 \\
\hline
\end{tabular}


Glacier Primitive Aret, Fremont Connt)-Continued

\begin{tabular}{|c|c|c|c|c|c|c|c|c|c|c|}
\hline \multirow[b]{2}{*}{ Sample } & \multicolumn{8}{|c|}{$\begin{array}{c}\text { Semiquant itat ive spect rographic } \\
\text { analyses--Cont inued } \\
\text { (ppm) }\end{array}$} & \multirow[b]{2}{*}{$\begin{array}{c}\text { Locat ion } \\
\text { Sec-Twp-Rge }\end{array}$} & \multirow[b]{2}{*}{ Remisrks } \\
\hline & $\begin{array}{l}\mathrm{Nb} \\
(10)\end{array}$ & $\begin{array}{l}\mathrm{Ni} \\
(5) \\
\end{array}$ & $\begin{array}{c}\mathrm{Pb} \\
(10)\end{array}$ & $\begin{array}{l}S c \\
\text { Sc } \\
\end{array}$ & $\begin{array}{r}5 r \\
(100)\end{array}$ & $\begin{array}{c}v \\
(10)\end{array}$ & $\begin{array}{c}Y \\
(10) \\
\end{array}$ & $\begin{array}{c}\mathrm{Zr} \\
(10) \\
\end{array}$ & & \\
\hline \multicolumn{11}{|c|}{ Migmatite samples--Cont inued } \\
\hline $\begin{array}{l}876 \\
877 \\
878 \\
882 \\
886\end{array}$ & $\begin{array}{l}N \\
L \\
L \\
L \\
L\end{array}$ & $\begin{array}{l}10 \\
10 \\
20 \\
10 \\
20\end{array}$ & $\begin{array}{l}20 \\
15 \\
30 \\
10 \\
20\end{array}$ & $\begin{array}{l}\mathrm{L} \\
\mathrm{N} \\
\mathrm{L} \\
\mathrm{L} \\
10\end{array}$ & $\begin{array}{l}300 \\
200 \\
300 \\
300 \\
500\end{array}$ & $\begin{array}{l}10 \\
30 \\
20 \\
30 \\
50\end{array}$ & $\begin{array}{r}N \\
N \\
\text { L } \\
30\end{array}$ & $\begin{array}{r}70 \\
70 \\
L \\
150 \\
150\end{array}$ & $\begin{array}{r}12-35-106 \\
1-35-106 \\
32-36-106 \\
4-35-106 \\
30-37-106\end{array}$ & $\begin{array}{l}\text { Mobile phase. } \\
\text { Do. } \\
\text { Gneiss phase. } \\
\text { Altered. } \\
\text { Garnet-bearing. }\end{array}$ \\
\hline $\begin{array}{l}889 \\
890 \\
892 \\
893 \\
894\end{array}$ & $\begin{array}{c}L \\
L \\
N \\
10 \\
N\end{array}$ & $\begin{array}{r}5 \\
20 \\
15 \\
15 \\
10\end{array}$ & $\begin{array}{l}L \\
L \\
20 \\
15 \\
15\end{array}$ & $\begin{array}{r}\text { N } \\
15 \\
N \\
7 \\
7\end{array}$ & $\begin{array}{l}150 \\
200 \\
300 \\
300 \\
200\end{array}$ & $\begin{array}{l}20 \\
10 \\
20 \\
20 \\
30\end{array}$ & $\begin{array}{r}\text { N } \\
30 \\
N \\
15 \\
N\end{array}$ & $\begin{array}{r}20 \\
10 \\
100 \\
100 \\
70\end{array}$ & $\begin{array}{r}4-35-106 \\
5-35-106 \\
6-35-106 \\
30-36-106 \\
19-36-106\end{array}$ & $\begin{array}{c}\text { Altered. } \\
\text { Mobile phase. } \\
\text { Gneiss phase. } \\
\text { Do. }\end{array}$ \\
\hline $\begin{array}{r}896 \\
900 \\
1101 \\
1102 \\
1103\end{array}$ & $\begin{array}{l}\text { N } \\
\text { L } \\
\text { L } \\
\text { L }\end{array}$ & $\begin{array}{r}20 \\
7 \\
7 \\
10 \\
10\end{array}$ & $\begin{array}{l}20 \\
15 \\
10 \\
15 \\
20\end{array}$ & $\begin{array}{l}5 \\
N \\
6 \\
N \\
L\end{array}$ & $\begin{array}{l}700 \\
200 \\
150 \\
500 \\
300\end{array}$ & $\begin{array}{l}30 \\
10 \\
15 \\
30 \\
30\end{array}$ & $\begin{array}{l}30 \\
\mathrm{~N} \\
\mathrm{~L} \\
\mathrm{~L} \\
20\end{array}$ & $\begin{array}{r}70 \\
20 \\
50 \\
100 \\
70\end{array}$ & $\begin{array}{r}7-36-106 \\
9-35-106 \\
4-35-106 \\
3-35-106 \\
33-36-106\end{array}$ & $\begin{array}{l}\text { Mobile phase. } \\
\text { Chloritized. } \\
\text { Altered. } \\
\text { Gneiss phase. }\end{array}$ \\
\hline $\begin{array}{l}1104 \\
1105 \\
1107 \\
1109 \\
1110\end{array}$ & $\begin{array}{l}L \\
N \\
L \\
L \\
L\end{array}$ & $\begin{array}{l}10 \\
1 \\
15 \\
20 \\
10\end{array}$ & $\begin{array}{l}20 \\
15 \\
20 \\
10 \\
15\end{array}$ & $\begin{array}{c}\mathrm{L} \\
\mathrm{N} \\
10 \\
\mathrm{~L} \\
5\end{array}$ & $\begin{array}{l}700 \\
300 \\
500 \\
200 \\
200\end{array}$ & $\begin{array}{r}30 \\
L \\
50 \\
15 \\
20\end{array}$ & $\begin{array}{r}20 \\
15 \\
30 \\
L \\
L\end{array}$ & $\begin{array}{r}N \\
30 \\
70 \\
100 \\
100\end{array}$ & $\begin{array}{c}9-35-106 \\
9-35-106 \\
2-35-106 \\
22-1-6 \\
2-36-106\end{array}$ & $\begin{array}{c}\text { Altered. } \\
\text { Do. } \\
\text { Altered. } \\
\text { Gneiss phase. }\end{array}$ \\
\hline 1111 & L & 7 & 15 & N & 150 & L & L & 100 & $31-37-106$ & Do. \\
\hline
\end{tabular}


TABLE 7.-Andyses of mafic and alsramafic rock samples

\begin{tabular}{|c|c|c|c|c|c|c|c|c|c|c|c|c|}
\hline \multicolumn{13}{|c|}{ tative spectrographic analyses } \\
\hline \multirow[b]{2}{*}{ Sample } & \multicolumn{4}{|c|}{ (Percent) } & \multicolumn{8}{|c|}{$(\mathrm{ppm})$} \\
\hline & $\begin{array}{c}F e \\
(0.5)\end{array}$ & $\begin{array}{c}\mathrm{Mg} \\
(.02)\end{array}$ & $\begin{array}{c}\mathrm{Ca} \\
(.05)\end{array}$ & $\begin{array}{c}\mathrm{Ti} \\
(.002)\end{array}$ & $\begin{array}{c}\mathrm{Mn} \\
(10) \\
\end{array}$ & $\begin{array}{c}\mathrm{B} \\
(10) \\
\end{array}$ & $\begin{array}{c}\mathrm{Ba} \\
(20) \\
\end{array}$ & $\begin{array}{l}\mathrm{Be} \\
\text { (1) }\end{array}$ & $\begin{array}{r}\text { co } \\
-(5) \\
\end{array}$ & $\begin{array}{l}\mathrm{Cr} \\
\text { (5) }\end{array}$ & $\begin{array}{r}\text { Cu } \\
\text { (5) } \\
\end{array}$ & $\begin{array}{r}\mathrm{La} \\
(20) \\
\end{array}$ \\
\hline \multicolumn{13}{|c|}{ Diabase and similar mafic rock samples } \\
\hline 24 & 7 & 5 & 7 & 0.3 & 700 & N & 70 & $\mathbf{N}$ & 70 & 150 & 70 & N \\
\hline 32 & 7 & 5 & 5 & .3 & 700 & L & 30 & N & 70 & 200 & 70 & $\mathrm{~N}$ \\
\hline 38 & 10 & 2 & 3 & 1 & 700 & $\grave{\imath}$ & 700 & $L$ & 70 & 10 & 30 & 70 \\
\hline 46 & 7 & 5 & 5 & .3 & 700 & N & 30 & $\mathrm{~N}$ & 70 & 150 & 70 & $\mathrm{~N}$ \\
\hline 47 & 3 & 5 & 3 & .3 & 500 & N & 20 & N & 30 & 150 & 50 & N \\
\hline 55 & 7 & 3 & 7 & .2 & 700 & N & L & $\mathbf{N}$ & 50 & 300 & 30 & N \\
\hline 111 & 5 & 3 & 3 & .3 & 700 & $\mathrm{~N}$ & 50 & N & 30 & 500 & 30 & $\mathrm{~N}$ \\
\hline 122 & 5 & 3 & 5 & .2 & 700 & N & L & N & 50 & 150 & 50 & $\mathrm{~N}$ \\
\hline 125 & 7 & 1.5 & 3 & .5 & 300 & N & 70 & $\ddot{L}$ & 50 & 7 & 300 & 70 \\
\hline 127 & 7 & 1.5 & 10 & .3 & 700 & L & 30 & $\mathbf{L}$ & 30 & 100 & 100 & N \\
\hline 128 & 7 & 5 & 5 & .3 & 700 & 10 & 50 & $\mathrm{~N}$ & 70 & 200 & 30 & N \\
\hline 182 & 3 & 3 & 0.5 & .7 & 300 & N & 20 & L & 15 & 30 & 10 & 30 \\
\hline 415 & 15 & 5 & 3 & 1 & 1,000 & N & 300 & $\mathbf{N}$ & 70 & 5 & 30 & 100 \\
\hline 420 & 7 & 7 & 3 & .3 & 700 & N & 100 & $\mathrm{~N}$ & 70 & 200 & 70 & $\mathrm{~N}$ \\
\hline 427 & 3 & 5 & 3 & .3 & 300 & N & 5,000 & 2 & 30 & 100 & 30 & 300 \\
\hline 4,33 & 7 & 2 & 1.5 & .5 & 700 & $\mathrm{~N}$ & 700 & N & 100 & 30 & 20 & 30 \\
\hline 448 & 7 & 3 & 3 & .7 & 1,000 & $\mathrm{~N}$ & 500 & $\mathrm{H}$ & 30 & 10 & 15 & 100 \\
\hline 472 & 7 & 5 & 5 & .5 & $i, 500$ & N & 200 & $\hat{N}$ & 70 & 1,000 & 70 & $\mathrm{~N}$ \\
\hline 476 & 15 & 2 & 5 & 1 & 2,000 & L & 150 & N & 70 & 100 & 200 & $\mathrm{~N}$ \\
\hline 508 & 7 & 3 & 5 & .2 & 700 & N & 300 & $\mathrm{~N}$ & 70 & 300 & 70 & n \\
\hline 514 & 7 & 3 & 10 & .3 & 1,500 & $\mathrm{~N}$ & 70 & N & 70 & 200 & 100 & $\mathrm{~N}$ \\
\hline 516 & 10 & 3 & 7 & .7 & 1,500 & 15 & 70 & $\ddot{L}$ & 70 & 200 & 100 & $\mathrm{~N}$ \\
\hline 529 & 10 & 1.5 & 3 & .7 & 2,000 & N & 70 & $\hat{N}$ & 70 & 20 & 30 & $\mathrm{~N}$ \\
\hline 536 & 10 & 5 & 3 & .5 & 1,500 & N & 70 & $\mathrm{~N}$ & 150 & 700 & 30 & N \\
\hline 546 & 10 & 3 & 5 & .5 & 1,500 & $\mathrm{~N}$ & 50 & $\mathrm{~N}$ & 100 & 500 & 15 & $\mathrm{~N}$ \\
\hline 547 & 10 & 5 & 7 & .2 & 100 & $\mathrm{~N}$ & 50 & N & 30 & 700 & 70 & $N$ \\
\hline .557 & 7 & 3 & 2 & .3 & 700 & N & 1,000 & i & 15 & 300 & 5 & 200 \\
\hline Bii & 15 & 2 & 3 & .5 & 1,500 & N & 150 & $\mathrm{~N}$ & 100 & 300 & 100 & $\mathrm{~N}$ \\
\hline 826 & 10 & 3 & 5 & .5 & 1,500 & L & 70 & $\mathbf{N}$ & 350 & 500 & 70 & N \\
\hline 851 & 20 & 3 & 3 & .5 & 3,500 & L & 150 & $\mathrm{~N}$ & 30 & 150 & 50 & N \\
\hline \multicolumn{13}{|c|}{ Biotite schist samples } \\
\hline 15 & 7 & 5 & 1 & 0.5 & 500 & N & 300 & $\mathbf{L}$ & 50 & 5 & 30 & L \\
\hline 16 & 5 & i & 2 & .2 & 500 & N & 300 & $\mathrm{~L}$ & 15 & 30 & 5 & 20 \\
\hline 19 & 3 & 1 & 2 & .2 & 300 & N & 500 & $i$ & 15 & 15 & 15 & 20 \\
\hline $23 \mathrm{y}$ & 7 & 1.5 & 0.15 & .15 & 300 & L & 500 & 3 & 15 & 300 & 15 & N \\
\hline $25 y$ & 7 & 3 & .07 & .15 & 500 & L & 300 & $\mathrm{~L}$ & 30 & 500 & 30 & N \\
\hline $31 y$ & 7 & 3 & .3 & .2 & 500 & L & 200 & $\mathrm{~L}$ & 30 & 700 & 70 & $\mathrm{~N}$ \\
\hline $35 \overline{1}$ & 3 & .7 & & .15 & 200 & $\mathrm{~N}$ & 200 & $i$ & 10 & 100 & 30 & 30 \\
\hline 45 & 3 & 1 & $i$ & .2 & 300 & N & 700 & L & 15 & 20 & 30 & 20 \\
\hline 72 & 3 & .7 & 1.5 & .2 & 150 & N & 700 & 1 & 10 & N & 7 & 150 \\
\hline 76 & 10 & 5 & 3 & .3 & 700 & N & 150 & $\mathrm{~N}$ & 70 & 150 & 50 & N \\
\hline 1142 & 3 & 3 & .7 & .2 & 300 & N & 50 & 1 & 30 & 70 & 15 & N \\
\hline 115 & 7 & 5 & 3 & .2 & 700 & N & 70 & L & 50 & $\mathrm{~L}$ & 20 & $\grave{L}$ \\
\hline 133 & 1.5 & 5 & .05 & .03 & 200 & $\mathrm{~N}$ & 150 & 1.5 & 5 & 5 & $\mathrm{~N}$ & 30 \\
\hline 155 & 7 & 3 & 1.5 & .5 & 700 & $\mathrm{~N}$ & 150 & L & 50 & 20 & 30 & N \\
\hline 167 & 7 & 3 & 3 & .5 & 700 & $\ddot{L}$ & 70 & L & 50 & 70 & 30 & N \\
\hline & & 1 & 3 & $>1$ & 1,000 & 10 & 200 & N & 20 & 10 & 200 & L \\
\hline 436 & 3 & 1.5 & .5 & .2 & 500 & $\mathrm{~N}$ & 20 & 1.5 & 10 & 15 & 20 & 50 \\
\hline $4373 /$ & 7 & 1.5 & 2 & .5 & 700 & N & 100 & $\mathrm{~L}$ & 50 & 70 & 30 & N \\
\hline 4384 & 2 & .5 & 1 & .15 & 150 & N & 100 & $i$ & 20 & 30 & 200 & 30 \\
\hline 440 & 7 & .5 & .3 & .1 & 70 & $\mathrm{~N}$ & 150 & i & L & 70 & 150 & N \\
\hline
\end{tabular}

y 2 n detected but below determination limit.

2) Contains 15 ppm Sn. 
Semiquantitative spectrographic analyses --Cont inued

\begin{tabular}{|c|c|c|c|c|c|c|c|c|c|c|}
\hline$\underline{\text { Sam }}$ & $\begin{array}{l}\text { No } \\
(10)\end{array}$ & $\begin{array}{c}\mathrm{Ni} \\
(5) \\
\end{array}$ & $\begin{array}{c}\mathrm{Pb} \\
(10)\end{array}$ & $\begin{array}{l}5 c \\
(5)\end{array}$ & $\begin{array}{c}5 r \\
(100)\end{array}$ & $\begin{array}{c}v \\
(10) \\
\end{array}$ & $\begin{array}{c}Y \\
(10) \\
\end{array}$ & $\begin{array}{c}\mathrm{Zr} \\
(10)\end{array}$ & $\begin{array}{c}\text { Locat ion } \\
\text { Sec-Twp-Rge }\end{array}$ & Remarks \\
\hline \multicolumn{11}{|c|}{ Diabase and similar mafic rock samples } \\
\hline $\begin{array}{l}24 \\
32 \\
38 \\
46 \\
47\end{array}$ & $\begin{array}{r}L \\
L \\
15 \\
L \\
N\end{array}$ & $\begin{array}{l}70 \\
70 \\
20 \\
70 \\
70\end{array}$ & $\begin{array}{l}N \\
L \\
L \\
L \\
L\end{array}$ & $\begin{array}{l}30 \\
30 \\
20 \\
30 \\
20\end{array}$ & $\begin{array}{l}100 \\
100 \\
700 \\
100 \\
100\end{array}$ & $\begin{array}{l}150 \\
150 \\
100 \\
150 \\
150\end{array}$ & $\begin{array}{l}15 \\
20 \\
30 \\
15 \\
15\end{array}$ & $\begin{array}{r}70 \\
50 \\
100 \\
30 \\
30\end{array}$ & $\begin{array}{r}13-38-106 \\
13-38-106 \\
1-38-106 \\
25-39-107 \\
25-39-107\end{array}$ & $\begin{array}{l}\text { Diabase. } \\
\text { Do. } \\
\text { Glomeroporphyritic. } \\
\text { Diabase. } \\
\text { Do. }\end{array}$ \\
\hline $\begin{array}{r}55 \\
111 \\
122 \\
125 \\
127\end{array}$ & $\begin{array}{l}\text { N } \\
\text { L } \\
\text { N } \\
\text { L } \\
\text { N }\end{array}$ & $\begin{array}{r}100 \\
70 \\
100 \\
50 \\
70\end{array}$ & $\begin{array}{c}\mathrm{L} \\
10 \\
N \\
15 \\
10\end{array}$ & $\begin{array}{l}30 \\
30 \\
20 \\
20 \\
20\end{array}$ & $\begin{array}{r}L \\
100 \\
L \\
300 \\
300\end{array}$ & $\begin{array}{r}150 \\
150 \\
150 \\
70 \\
150\end{array}$ & $\begin{array}{r}15 \\
15 \\
15 \\
100 \\
30\end{array}$ & $\begin{array}{r}20 \\
30 \\
30 \\
150 \\
20\end{array}$ & $\begin{array}{l}29-39-106 \\
13-38-106 \\
10-38-106 \\
10-38-106 \\
10-38-106\end{array}$ & $\begin{array}{l}\text { Mafic porphyry; float. } \\
\text { Diabase. } \\
\text { Do. } \\
\text { Do. } \\
\text { Do. }\end{array}$ \\
\hline $\begin{array}{l}128 \\
182 \\
415 \\
420 \\
427\end{array}$ & $\begin{array}{r}N \\
10 \\
10 \\
L \\
L\end{array}$ & $\begin{array}{r}100 \\
15 \\
20 \\
70 \\
150\end{array}$ & $\begin{array}{l}N \\
L \\
L \\
L \\
70\end{array}$ & $\begin{array}{l}30 \\
15 \\
20 \\
30 \\
10\end{array}$ & $\begin{array}{r}150 \\
\mathrm{~N} \\
300 \\
150 \\
3,000\end{array}$ & $\begin{array}{r}150 \\
50 \\
100 \\
150 \\
30\end{array}$ & $\begin{array}{l}15 \\
10 \\
30 \\
10 \\
20\end{array}$ & $\begin{array}{r}30 \\
300 \\
100 \\
30 \\
200\end{array}$ & $\begin{array}{r}36-39-107 \\
2-41-107 \\
15-38-106 \\
16-39-107 \\
35-39-107\end{array}$ & $\begin{array}{l}\text { Do. } \\
\text { Mafic dike. } \\
\text { Glomeroporphyritic. } \\
\text { Diabase. } \\
\text { Do. }\end{array}$ \\
\hline $\begin{array}{l}433 \\
448 \\
472 \\
476 \\
508\end{array}$ & $\begin{array}{r}10 \\
L \\
N \\
L \\
L\end{array}$ & $\begin{array}{r}30 \\
7 \\
300 \\
70 \\
150\end{array}$ & $\begin{array}{r}N \\
10 \\
N \\
N \\
15\end{array}$ & $\begin{array}{l}15 \\
15 \\
70 \\
70 \\
30\end{array}$ & $\begin{array}{r}700 \\
500 \\
150 \\
200 \\
L\end{array}$ & $\begin{array}{r}100 \\
70 \\
300 \\
700 \\
150\end{array}$ & $\begin{array}{l}20 \\
30 \\
15 \\
70 \\
20\end{array}$ & $\begin{array}{r}50 \\
70 \\
50 \\
150 \\
30\end{array}$ & $\begin{array}{r}34-38-107 \\
20-38-106 \\
32-41-108 \\
21-41-108 \\
6-38-106\end{array}$ & $\begin{array}{l}\text { Glome roporphyritic. } \\
\text { Do. } \\
\text { Diabase. } \\
\text { Do. } \\
\text { Mafic dike. }\end{array}$ \\
\hline $\begin{array}{l}514 \\
516 \\
529 \\
536 \\
546\end{array}$ & $\begin{array}{l}L \\
L \\
L \\
N \\
2\end{array}$ & $\begin{array}{r}70 \\
70 \\
20 \\
150 \\
70\end{array}$ & $\begin{array}{l}\mathrm{N} \\
\mathrm{N} \\
\mathrm{N} \\
\mathrm{N} \\
\mathrm{N}\end{array}$ & $\begin{array}{l}50 \\
50 \\
70 \\
70 \\
30\end{array}$ & $\begin{array}{r}150 \\
300 \\
L \\
200 \\
N\end{array}$ & $\begin{array}{l}150 \\
200 \\
300 \\
200 \\
300\end{array}$ & $\begin{array}{l}15 \\
20 \\
30 \\
20 \\
20\end{array}$ & $\begin{array}{l}50 \\
70 \\
50 \\
20 \\
50\end{array}$ & $\begin{array}{r}12-39-108 \\
35-40-108 \\
29-38-105 \\
7-37-105 \\
28-38-105\end{array}$ & $\begin{array}{l}\text { Diabase near fault. } \\
\text { Diabase. } \\
\text { Do. } \\
\text { Do. } \\
\text { Do. }\end{array}$ \\
\hline $\begin{array}{l}547 \\
557 \\
811 \\
826 \\
851\end{array}$ & $\begin{array}{l}L \\
L \\
L \\
L\end{array}$ & $\begin{array}{r}70 \\
70 \\
100 \\
150 \\
50\end{array}$ & $\begin{array}{l}10 \\
15 \\
N \\
N \\
L\end{array}$ & $\begin{array}{l}30 \\
15 \\
50 \\
50 \\
50\end{array}$ & $\begin{array}{r}150 \\
300 \\
100 \\
150 \\
L\end{array}$ & $\begin{array}{r}150 \\
70 \\
200 \\
200 \\
200\end{array}$ & $\begin{array}{l}20 \\
70 \\
20 \\
15 \\
50\end{array}$ & $\begin{array}{r}15 \\
150 \\
70 \\
50 \\
50\end{array}$ & $\begin{array}{l}15-3-6 \\
14-37-106 \\
35-41-107 \\
19-38-105 \\
20-38-105\end{array}$ & $\begin{array}{l}\text { Do. } \\
\text { Do. } \\
\text { Do. } \\
\text { Do. } \\
\text { Hornblende-rich dike. }\end{array}$ \\
\hline \multicolumn{11}{|c|}{ Biotite schist samples } \\
\hline $\begin{array}{l}15 \\
16 \\
19 \\
23 \\
25\end{array}$ & $\begin{array}{l}\mathbf{L} \\
\mathbf{L} \\
\mathbf{L} \\
\mathrm{N} \\
\mathrm{N}\end{array}$ & $\begin{array}{r}70 \\
15 \\
15 \\
100 \\
100\end{array}$ & $\begin{array}{r}10 \\
L \\
15 \\
L \\
30\end{array}$ & $\begin{array}{r}30 \\
10 \\
10 \\
5 \\
15\end{array}$ & $\begin{array}{r}\mathrm{L} \\
200 \\
150 \\
\mathrm{~N} \\
\mathrm{~N}\end{array}$ & $\begin{array}{r}150 \\
70 \\
70 \\
50 \\
100\end{array}$ & $\begin{array}{r}15 \\
15 \\
15 \\
N \\
15\end{array}$ & $\begin{array}{r}150 \\
100 \\
100 \\
20 \\
70\end{array}$ & $\begin{array}{r}17-37-106 \\
16-37-106 \\
4-37-106 \\
34-38-106 \\
34-38-106\end{array}$ & $\begin{array}{l}\text { Biotite-rich gneiss. } \\
\text { Do. } \\
\text { Do. } \\
\text { Biotite-sericite-quartz. } \\
\text { Do. }\end{array}$ \\
\hline $\begin{array}{l}31 \\
35 \\
45 \\
72 \\
76\end{array}$ & $\begin{array}{c}\mathrm{L} \\
\mathrm{L} \\
\mathrm{L} \\
10 \\
\mathrm{H}\end{array}$ & $\begin{array}{r}150 \\
70 \\
20 \\
1 \\
100\end{array}$ & $\begin{array}{l}N \\
15 \\
15 \\
15 \\
10\end{array}$ & $\begin{array}{r}20 \\
10 \\
10 \\
7 \\
30\end{array}$ & $\begin{array}{r}N \\
L \\
100 \\
100 \\
L\end{array}$ & $\begin{array}{r}150 \\
70 \\
70 \\
50 \\
150\end{array}$ & $\begin{array}{l}20 \\
10 \\
20 \\
30 \\
20\end{array}$ & $\begin{array}{r}70 \\
100 \\
150 \\
300 \\
50\end{array}$ & $\begin{array}{l}26-38-106 \\
13-38-106 \\
25-39-107 \\
14-39-106 \\
32-39-106\end{array}$ & $\begin{array}{l}\text { Biotite in shear. } \\
\text { Do. } \\
\text { Biotite-rich gneiss. } \\
\text { Biotite-schist lens. } \\
\text { Do. }\end{array}$ \\
\hline $\begin{array}{l}114 \\
115 \\
133 \\
155 \\
167\end{array}$ & $\begin{array}{r}15 \\
L \\
20 \\
L \\
L\end{array}$ & $\begin{array}{l}50 \\
70 \\
10 \\
20 \\
70\end{array}$ & $\begin{array}{r}10 \\
10 \\
L \\
10 \\
10\end{array}$ & $\begin{array}{r}15 \\
20 \\
7 \\
20 \\
15\end{array}$ & $\begin{array}{r}N \\
N \\
N \\
100 \\
L\end{array}$ & $\begin{array}{r}70 \\
150 \\
15 \\
150 \\
100\end{array}$ & $\begin{array}{l}30 \\
30 \\
30 \\
50 \\
30\end{array}$ & $\begin{array}{r}50 \\
30 \\
200 \\
200 \\
70\end{array}$ & $\begin{array}{r}14-38-106 \\
11-38-106 \\
20-39-106 \\
3-38-106 \\
15-39-107\end{array}$ & $\begin{array}{l}\text { Do. } \\
\text { Do. } \\
\text { Mica schist. } \\
\text { Biotite-rich gneiss. } \\
\text { Do. }\end{array}$ \\
\hline $\begin{array}{l}193 \\
436 \\
437 \\
438 \\
440\end{array}$ & $\begin{array}{r}20 \\
20 \\
L \\
L \\
10\end{array}$ & $\begin{array}{l}\mathrm{L} \\
\mathrm{L} \\
30 \\
20 \\
\mathrm{~L}\end{array}$ & $\begin{array}{r}10 \\
N \\
L \\
15 \\
15\end{array}$ & $\begin{array}{r}50 \\
10 \\
20 \\
5 \\
7\end{array}$ & $\begin{array}{r}N \\
100 \\
L \\
100 \\
100\end{array}$ & $\begin{array}{r}150 \\
30 \\
200 \\
30 \\
15\end{array}$ & $\begin{array}{r}>200 \\
70 \\
50 \\
30 \\
\mathrm{~N}\end{array}$ & $\begin{array}{l}300 \\
700 \\
100 \\
100 \\
300\end{array}$ & $\begin{array}{r}1-37-107 \\
25-38-107 \\
25-38-107 \\
25-38-107 \\
30-38-106\end{array}$ & $\begin{array}{l}\text { Biotite in shear. } \\
\text { Biotite-schist lens. } \\
\text { Do. } \\
\text { Biotite schist and pyrite. } \\
\text { Biotite schist and gossen. }\end{array}$ \\
\hline
\end{tabular}

3) Contains $200 \mathrm{ppm} 2 \mathrm{n}$.

4. Contains 5 ppm Mo. 
TABLE 7.-Analyses of mafic and ulramafic rock samples from

\begin{tabular}{|c|c|c|c|c|c|c|c|c|c|c|c|c|}
\hline \multicolumn{13}{|c|}{ Semiquantitative spectrographic analyses } \\
\hline & \multicolumn{4}{|c|}{ (Percent) } & \multicolumn{8}{|c|}{$(\mathrm{ppm})$} \\
\hline Sample. & $\begin{array}{c}\mathrm{Fe} \\
(0.5)\end{array}$ & $\begin{array}{c}\mathrm{Mg} \\
(.02) \\
\end{array}$ & $\begin{array}{c}c a \\
(.05) \\
\end{array}$ & $\begin{array}{c}\mathrm{Ti} \\
(.002) \\
\end{array}$ & $\begin{array}{l}\text { Mn } \\
(10)\end{array}$ & $\begin{array}{c}\mathrm{B} \\
(10)\end{array}$ & $\begin{array}{r}\text { Ba } \\
(20) \\
\end{array}$ & $\begin{array}{l}8 \mathrm{e} \\
(1)\end{array}$ & $\begin{array}{l}\text { Co } \\
\text { (5) }\end{array}$ & $\begin{array}{l}C r \\
(5)\end{array}$ & $\begin{array}{l}\text { Cu } \\
(5)\end{array}$ & $\begin{array}{l}\mathrm{La} \\
(20) \\
\end{array}$ \\
\hline \multicolumn{13}{|c|}{ Biotite schist sangles--Continued } \\
\hline $\begin{array}{l}4475 \\
533 \\
5506 \\
565 \\
814\end{array}$ & $\begin{array}{r}15 \\
5 \\
5 \\
7 \\
2\end{array}$ & $\begin{array}{l}1 \\
2 \\
1.5 \\
3 \\
0.7\end{array}$ & $\begin{array}{l}0.07 \\
1 \\
3 \\
.7 \\
.1\end{array}$ & $\begin{array}{l}0.2 \\
.2 \\
.3 \\
.3 \\
.02\end{array}$ & $\begin{array}{l}200 \\
700 \\
500 \\
700 \\
150\end{array}$ & $\begin{array}{l}30 \\
N \\
N \\
N \\
N\end{array}$ & $\begin{array}{r}70 \\
500 \\
700 \\
50 \\
500\end{array}$ & $\begin{array}{l}N \\
N \\
N \\
N \\
5\end{array}$ & $\begin{array}{r}700 \\
50 \\
20 \\
30 \\
\mathrm{~N}\end{array}$ & $\begin{array}{r}200 \\
700 \\
500 \\
500 \\
L\end{array}$ & $\begin{array}{r}700 \\
20 \\
100 \\
L \\
70\end{array}$ & $\begin{array}{r}\mathrm{N} \\
\mathrm{L} \\
70 \\
70 \\
\mathrm{~L}\end{array}$ \\
\hline $\begin{array}{l}818 \\
859\end{array}$ & $\begin{array}{l}10 \\
10\end{array}$ & $\begin{array}{r}10 \\
7\end{array}$ & $2^{.7}$ & $\begin{array}{l}.1 \\
.3\end{array}$ & $\begin{array}{r}700 \\
1,000\end{array}$ & $\mathbf{N}$ & $\begin{array}{r}20 \\
500\end{array}$ & $\begin{array}{l}\mathbf{N} \\
\mathbf{N}\end{array}$ & $\begin{array}{r}150 \\
50\end{array}$ & $\begin{array}{l}2,000 \\
1,500\end{array}$ & $\begin{array}{r}15 \\
\mathrm{~L}\end{array}$ & $\begin{array}{l}\mathrm{N} \\
\mathrm{N}\end{array}$ \\
\hline \multicolumn{13}{|c|}{ Amphibolite samples } \\
\hline $\begin{array}{r}87 \\
106 \\
110 \\
132 \\
138\end{array}$ & $\begin{array}{l}7 \\
3 \\
7 \\
5 \\
7\end{array}$ & $\begin{array}{l}5 \\
7 \\
5 \\
5 \\
7\end{array}$ & $\begin{array}{l}3 \\
5 \\
5 \\
1 \\
5\end{array}$ & $\begin{array}{l}0.7 \\
.2 \\
.3 \\
.5 \\
.15\end{array}$ & $\begin{array}{l}500 \\
700 \\
700 \\
300 \\
700\end{array}$ & $\begin{array}{l}\mathbf{N} \\
\mathbf{N} \\
\mathbf{N} \\
\mathrm{N} \\
\mathbf{N}\end{array}$ & $\begin{array}{r}150 \\
50 \\
70 \\
L \\
70\end{array}$ & $\begin{array}{l}\mathbf{N} \\
\mathrm{N} \\
\mathrm{N} \\
\mathrm{L} \\
\mathrm{N}\end{array}$ & $\begin{array}{l}30 \\
50 \\
70 \\
30 \\
70\end{array}$ & $\begin{array}{l}20 \\
150 \\
150 \\
150 \\
500\end{array}$ & $\begin{array}{r}20 \\
5 \\
70 \\
L \\
30\end{array}$ & $\begin{array}{r}20 \\
\mathrm{~L} \\
\mathrm{~N} \\
70 \\
\mathrm{~N}\end{array}$ \\
\hline $\begin{array}{l}139 \\
158 y \\
166 \\
169 \\
183\end{array}$ & $\begin{array}{l}5 \\
3 \\
7 \\
7 \\
7\end{array}$ & $\begin{array}{l}2 \\
3 \\
5 \\
7 \\
7\end{array}$ & $\begin{array}{l}2 \\
7 \\
5 \\
5\end{array}$ & $\begin{array}{l}.3 \\
.15 \\
.5 \\
.2 \\
.5\end{array}$ & $\begin{array}{r}700 \\
200 \\
700 \\
1,000 \\
700\end{array}$ & $\begin{array}{l}10 \\
N \\
\text { L } \\
N \\
N\end{array}$ & $\begin{array}{r}150 \\
L \\
300 \\
50 \\
300\end{array}$ & $\begin{array}{l}L \\
L \\
N \\
L \\
N\end{array}$ & $\begin{array}{r}30 \\
100 \\
70 \\
50 \\
50\end{array}$ & $\begin{array}{l}70 \\
150 \\
300 \\
500 \\
300\end{array}$ & $\begin{array}{r}15 \\
\mathrm{~L} \\
100 \\
15 \\
50\end{array}$ & $\begin{array}{r}20 \\
N \\
N \\
N \\
30\end{array}$ \\
\hline $\begin{array}{l}186 \\
194 \\
195 \\
422 \\
449\end{array}$ & $\begin{array}{r}5 \\
7 \\
10 \\
7 \\
7\end{array}$ & $\begin{array}{l}3 \\
5 \\
3 \\
7 \\
3\end{array}$ & $\begin{array}{l}5^{.1} \\
1 \\
5 \\
3\end{array}$ & $\begin{array}{l}.2 \\
.2 \\
.3 \\
.15 \\
.2\end{array}$ & $\begin{array}{l}300 \\
700 \\
700 \\
700 \\
700\end{array}$ & $\begin{array}{l}\mathbf{N} \\
\mathbf{N} \\
\mathbf{N} \\
\mathbf{N} \\
\mathrm{N}\end{array}$ & $\begin{array}{r}70 \\
100 \\
700 \\
70 \\
150\end{array}$ & $\begin{array}{l}1 \\
\mathrm{~L} \\
1.5 \\
\mathrm{~N} \\
\mathrm{~N}\end{array}$ & $\begin{array}{l}15 \\
50 \\
30 \\
70 \\
50\end{array}$ & $\begin{array}{r}150 \\
15 \\
3,000 \\
150 \\
300\end{array}$ & $\begin{array}{l}15 \\
15 \\
70 \\
30 \\
30\end{array}$ & $\begin{array}{l}30 \\
\mathbf{N} \\
\mathbf{N} \\
\mathrm{N}\end{array}$ \\
\hline $\begin{array}{l}470 \\
506 \\
509 \\
538 \\
560\end{array}$ & $\begin{array}{l}7 \\
7 \\
7 \\
7 \\
3\end{array}$ & $\begin{array}{l}1.5 \\
2 \\
3 \\
5 \\
3\end{array}$ & $\begin{array}{l}5 \\
7 \\
3 \\
5 \\
3\end{array}$ & $\begin{array}{l}1 \\
.3 \\
.15 \\
.15 \\
.2\end{array}$ & $\begin{array}{r}1,500 \\
700 \\
700 \\
1,000 \\
1,000\end{array}$ & $\begin{array}{l}\mathbf{N} \\
\mathbf{N} \\
\mathbf{N} \\
\mathbf{N} \\
\mathbf{N}\end{array}$ & $\begin{array}{r}150 \\
100 \\
150 \\
30 \\
700\end{array}$ & $\begin{array}{l}\mathbf{L} \\
\mathbf{N} \\
\mathbf{N} \\
\mathbf{N} \\
\mathbf{N}\end{array}$ & $\begin{array}{r}30 \\
50 \\
70 \\
150 \\
20\end{array}$ & $\begin{array}{r}20 \\
100 \\
500 \\
3,000 \\
500\end{array}$ & $\begin{array}{r}50 \\
100 \\
15 \\
L \\
7\end{array}$ & $\begin{array}{r}N \\
N \\
N \\
N \\
100\end{array}$ \\
\hline $\begin{array}{l}561 \\
809 \\
842 \\
868 \%\end{array}$ & $\begin{array}{r}3 \\
15 \\
15 \\
20\end{array}$ & $\begin{array}{l}1.5 \\
5 \\
5 \\
5\end{array}$ & $\begin{array}{l}2 \\
3 \\
5 \\
1\end{array}$ & $\begin{array}{l}.2 \\
.7 \\
.3 \\
.15\end{array}$ & $\begin{array}{r}300 \\
1,500 \\
1,000 \\
1,500\end{array}$ & $\begin{array}{l}\mathbf{N} \\
N \\
L \\
L\end{array}$ & $\begin{array}{r}700 \\
70 \\
200 \\
300\end{array}$ & $\begin{array}{l}\mathrm{N} \\
\mathrm{L} \\
\mathrm{N} \\
\mathrm{N}\end{array}$ & $\begin{array}{r}10 \\
150 \\
30 \\
70\end{array}$ & $\begin{array}{r}30 \\
1,500 \\
500 \\
700\end{array}$ & $\begin{array}{r}15 \\
100 \\
L \\
10\end{array}$ & $\begin{array}{l}50 \\
\mathrm{~N} \\
\mathrm{~N} \\
\mathrm{~N}\end{array}$ \\
\hline \multicolumn{13}{|c|}{ Ultramafic rock samples } \\
\hline $\begin{array}{l}13 \frac{1}{13} \\
215 \\
34 \\
60 \\
90\end{array}$ & $\begin{array}{l}5 \\
7 \\
5 \\
5 \\
5\end{array}$ & $\begin{array}{r}10 \\
10 \\
7 \\
10 \\
>10\end{array}$ & $\begin{array}{l}5 \\
1.5 \\
1.5 \\
2.2\end{array}$ & $\begin{array}{l}.05 \\
.05 \\
.07 \\
.005 \\
.05\end{array}$ & $\begin{array}{r}7,500 \\
500 \\
700 \\
700 \\
700\end{array}$ & $\begin{array}{l}\mathbf{N} \\
\mathbf{N} \\
\mathbf{L} \\
\mathbf{N}\end{array}$ & $\begin{array}{c}30 \\
L \\
L \\
L \\
20\end{array}$ & $\begin{array}{l}\mathbf{N} \\
\mathbf{N} \\
\mathbf{N} \\
\mathbf{N} \\
\mathbf{N}\end{array}$ & $\begin{array}{r}50 \\
70 \\
70 \\
70 \\
200\end{array}$ & $\begin{array}{r}2,000 \\
3,000 \\
3,000 \\
700 \\
5,000\end{array}$ & $\begin{array}{r}\mathrm{L} \\
15 \\
\mathrm{~L} \\
\mathrm{~L} \\
30\end{array}$ & $\begin{array}{l}N \\
N \\
N \\
N \\
N\end{array}$ \\
\hline $\begin{array}{l}150 \\
459 \\
460 \\
462 \\
501\end{array}$ & $\begin{array}{r}5 \\
20 \\
7 \\
>20 \\
7\end{array}$ & $\begin{array}{l}7 \\
0.7 \\
5 \\
1 \\
3\end{array}$ & $\begin{array}{l}3 \\
2^{.07} \\
5\end{array}$ & $\begin{array}{l}.15 \\
.1 \\
.07 \\
.03 \\
.2\end{array}$ & $\begin{array}{l}700 \\
100 \\
500 \\
150 \\
700\end{array}$ & $\begin{array}{r}N \\
N \\
10 \\
N \\
30\end{array}$ & $\begin{array}{r}70 \\
50 \\
L \\
50 \\
150\end{array}$ & $\begin{array}{l}N \\
N \\
5 \\
L \\
N\end{array}$ & $\begin{array}{r}70 \\
30 \\
30 \\
15 \\
100\end{array}$ & $\begin{array}{r}1,000 \\
5,000 \\
1,500 \\
>5,000 \\
500\end{array}$ & $\begin{array}{r}15 \\
7 \\
10 \\
1 \\
70\end{array}$ & $\begin{array}{l}\mathbf{N} \\
\mathbf{N} \\
\mathbf{N} \\
\mathbf{N} \\
\mathbf{N}\end{array}$ \\
\hline $\begin{array}{l}502 \\
507 \\
524 \\
534 \\
539\end{array}$ & $\begin{array}{r}10 \\
7 \\
10 \\
7 \\
10\end{array}$ & $\begin{array}{r}3 \\
7 \\
>10 \\
7 \\
7\end{array}$ & $\begin{array}{l}5 \\
2 \\
1.5 \\
5 \\
3\end{array}$ & $\begin{array}{l}.3 \\
.1 \\
.15 \\
.3 \\
.5\end{array}$ & $\begin{array}{r}1,000 \\
700 \\
1,500 \\
1,500 \\
1,500\end{array}$ & $\begin{array}{l}\mathrm{L} \\
\mathbf{N} \\
\mathrm{L} \\
\mathrm{N} \\
\mathrm{N}\end{array}$ & $\begin{array}{r}100 \\
50 \\
30 \\
150 \\
30\end{array}$ & $\begin{array}{l}\mathrm{N} \\
\mathrm{N} \\
\mathrm{N} \\
\mathrm{N} \\
\mathrm{N}\end{array}$ & $\begin{array}{l}150 \\
200 \\
150 \\
100 \\
150\end{array}$ & $\begin{array}{r}300 \\
3,000 \\
3,000 \\
3,000 \\
3,000\end{array}$ & $\begin{array}{r}150 \\
15 \\
5 \\
50 \\
300\end{array}$ & $\begin{array}{l}N \\
N \\
N \\
N \\
N\end{array}$ \\
\hline $\begin{array}{l}821 \\
822 \\
823 \\
835 \\
837\end{array}$ & $\begin{array}{r}7 \\
7 \\
7 \\
7 \\
10\end{array}$ & $\begin{array}{r}10 \\
7 \\
7 \\
7 \\
7\end{array}$ & $\begin{array}{l}1 \\
1.5 \\
2 \\
5.2\end{array}$ & $\begin{array}{l}.1 \\
.1 \\
.2 \\
.2 \\
.03\end{array}$ & $\begin{array}{r}1,000 \\
700 \\
700 \\
1,000 \\
500\end{array}$ & $\begin{array}{l}\mathbf{N} \\
\mathbf{N} \\
\mathbf{N} \\
\mathbf{N} \\
\mathbf{N}\end{array}$ & $\begin{array}{r}\mathbf{N} \\
\mathbf{N} \\
\mathbf{N} \\
20 \\
\mathbf{L}\end{array}$ & $\begin{array}{l}\mathbf{N} \\
\mathbf{N} \\
\mathbf{N} \\
\mathbf{N} \\
\mathbf{N}\end{array}$ & $\begin{array}{r}150 \\
150 \\
150 \\
50 \\
70\end{array}$ & $\begin{array}{r}>5,000 \\
>5,000 \\
3,000 \\
3,000 \\
>5,000\end{array}$ & $\begin{array}{r}70 \\
200 \\
30 \\
L \\
L\end{array}$ & $\begin{array}{l}\mathbf{N} \\
\mathbf{N} \\
\mathbf{N} \\
\mathbf{N} \\
\mathbf{N}\end{array}$ \\
\hline
\end{tabular}

5) Contains $100 \mathrm{ppm}$ Mo.

6. Contains $7 \mathrm{ppm}$ Mo. 
Semiquantitative spectrographic anslyses--Continued

\begin{tabular}{|c|c|c|c|c|c|c|c|c|}
\hline & \multicolumn{6}{|c|}{$(\mathrm{ppm})$} & \multirow[b]{2}{*}{$\begin{array}{c}\text { Location } \\
\text { Sec-Twp-Rge }\end{array}$} & \multirow[b]{2}{*}{ Remarks } \\
\hline $\begin{array}{cc}\mathrm{Nb} \\
\text { Sample } & (10)\end{array}$ & $\begin{array}{l}\mathrm{Ni} \\
(5)\end{array}$ & $\begin{array}{l}\text { Pि } \\
\text { (10) }\end{array}$ & $\begin{array}{ll}5 c & 5 r \\
(5) & (100)\end{array}$ & $\begin{array}{c}V \\
(10)\end{array}$ & $\begin{array}{c}Y \\
(10)\end{array}$ & $\begin{array}{l}\mathrm{Zr} \\
(10)\end{array}$ & & \\
\hline
\end{tabular}

Biotite schist samples--Continued

\begin{tabular}{|c|c|}
\hline $\begin{array}{l}447 \\
533 \\
550 \\
565 \\
814\end{array}$ & $\begin{array}{r}10 \\
L \\
1 \\
L \\
N\end{array}$ \\
\hline $\begin{array}{l}818 \\
859\end{array}$ & $\frac{2}{10}$ \\
\hline
\end{tabular}

300
150
30
150
$\mathrm{~N}$
3,000
200

$\begin{array}{rrrr}15 & 10 & N & 100 \\ \text { L } & 15 & N & 100 \\ 50 & 15 & 200 & 150 \\ 10 & 20 & 100 & 100\end{array}$

$\begin{array}{ll}50 & 200 \\ 15 & 100 \\ 15 & 100 \\ 30 & 150 \\ N & 100\end{array}$

20-38-106

$13-37-106$

$21-37-106$

20-38-105

$26-38-106$

$31-38-105$

$20-37-105$

Amphibolite samples

13

1

87
06
10
32
38
39
58
66
169
83
86
94
95
422
49
470
506
509
38
560
561
899
412
868

$L$
$L$
$L$

50
100
70
100
150

$\begin{array}{rrr}15 & 30 & 150 \\ 10 & 30 & 100 \\ \text { L. } & 30 & 200 \\ \text { L } & 10 & \\ \mathrm{~N} & 30\end{array}$

$\begin{array}{rr}150 & 200 \\ 100 & 150 \\ 200 & 150 \\ N & 7\end{array}$

200

150

100

$\begin{array}{lr}50 & 150 \\ 20 & 50 \\ 20 & 70 \\ 30 & 150 \\ 15 & 10\end{array}$

50
50
70
150

1-39-107

23-38-106

$13-38-106$

29-39-106

$12-38-106$

15-39-106

19-39-106

15-39-107

$14-39-107$

$18-40-107$

5-40-107

1-37-107

1-37-107

27-39-107

21-38-106

$12-40-108$

20-39-105

29-39-105

$19-37-105$

7-36-106

2-36-105

$34-41-107$

$35-37-106$

$15-36-106$

\section{Ultramafic rock samples}

21
34
60
90

150
459
460
462
501
502
507
524
534
539
821
822
823
835
837

1,000

700

1.500

3,000

3,000

150
200
1,500

1,500

$\begin{array}{lll}N & 30 \\ & N & 15\end{array}$

150 N 15

$150+N$

$100 L 30$

2,000

3,000

300

1,000

10

$$
\begin{array}{r}
2,000 \\
1,500 \\
500 \\
700
\end{array}
$$

2.000

$\begin{array}{ll}N & 30 \\ N & 20 \\ N & 30 \\ N & 15 \\ L & 7\end{array}$

24-39-106

21-40-107

$21-40-107$

6-40-107

13-39-106

$1-38-106$

23-41-108

$13-37-106$

$19-37-105$

19-38-105

$19-38-105$

19-38-105

$36-37-106$

$35-37-106$

Biot ite-quartz-pyrite.

Biotite-rich inclusion.

Biotite-rich shear.

Biotite-rich shear (altered).

Biotite schist lens.

Do.

Irregular mass.

Dike (?)

Irregular mass.

Ultramafic(?).

I rregular mass.

Do

Iron-stained.

Irregular mass.

Do.

Do.

Do.

Sheared.

Irregular mass (?).

Do.

Layer in gneiss.

Irregular mass.

Do.

Layer in gneiss.

Irreguiar mass.

Biotite schist(?)

Layer in granite.

With scattered plagioclase.

In fold crest.

Anthophyllite-chlorite.

Irregular body.

In fault zone.

Talc-chlorite.

Do.

Dikelike body.

Magnetite-rich body. Do.

Float.

Dike like body.

Do.

Do.

Do.

Tremolite-chlorite.

Do.

Do.

Do.

Dikelike body.

Serpentine.

y Contains $30 \mathrm{ppm}$ Mo.

8) Contains $300 \mathrm{ppm} \mathrm{Zn}$. 
Semiquantitative spectrographic analyses

\begin{tabular}{|c|c|c|c|c|c|c|c|c|c|c|c|c|}
\hline & \multicolumn{4}{|c|}{ (Percent) } & \multicolumn{8}{|c|}{$(\mathrm{ppm})$} \\
\hline Sample & $\begin{array}{c}\overline{F e} \\
(0.5)\end{array}$ & $\begin{array}{c}\mathrm{Mg} \\
(.02)\end{array}$ & $\begin{array}{c}\mathrm{Ca} \\
(.05) \\
\end{array}$ & $\begin{array}{c}\mathrm{Ti} \\
(.002) \\
\end{array}$ & $\begin{array}{c}M_{n} \\
(10)\end{array}$ & $\begin{array}{c}B \\
\text { (10) }\end{array}$ & $\begin{array}{c}\mathbf{B a} \\
(20)\end{array}$ & $\begin{array}{l}\mathrm{Be} \\
\text { (1) }\end{array}$ & $\begin{array}{l}\text { Co } \\
\text { (5) }\end{array}$ & $\begin{array}{l}C \overrightarrow{C r} \\
(5)\end{array}$ & $\begin{array}{l}\mathrm{Cu} \\
(5)\end{array}$ & $\begin{array}{c}\text { La } \\
(20)\end{array}$ \\
\hline
\end{tabular}

Ultramafic rock samples--Cont i nued

\begin{tabular}{|c|c|c|c|c|c|c|c|c|c|c|c|c|}
\hline $\begin{array}{l}8384 \\
839 \\
840 \\
841 \\
844\end{array}$ & $\begin{array}{r}5 \\
20 \\
15 \\
10 \\
20\end{array}$ & $\begin{array}{l}5 \\
7 \\
7 \\
7 \\
7\end{array}$ & $\begin{array}{l}7 \\
0.1 \\
3 \\
5 \\
1.5\end{array}$ & $\begin{array}{l}0.02 \\
.015 \\
.1 \\
.1 \\
.15\end{array}$ & $\begin{array}{r}1,000 \\
500 \\
1,500 \\
3,000 \\
1,000\end{array}$ & $\begin{array}{l}\mathbf{N} \\
\mathbf{L} \\
\mathbf{N} \\
\mathbf{N} \\
\mathbf{N}\end{array}$ & $\begin{array}{r}200 \\
50 \\
N \\
100 \\
30\end{array}$ & $\begin{array}{l}\mathbf{I} \\
\mathrm{L} \\
\mathrm{N} \\
\mathrm{N} \\
\mathrm{N}\end{array}$ & $\begin{array}{r}30 \\
70 \\
70 \\
20 \\
200\end{array}$ & $\begin{array}{r}300 \\
>5,000 \\
>5,000 \\
3,000 \\
>5,000\end{array}$ & $\begin{array}{r}\mathrm{L} \\
N \\
N \\
15 \\
200\end{array}$ & $\begin{array}{l}\mathrm{N} \\
\mathrm{N} \\
\mathrm{N} \\
\mathrm{N} \\
\mathrm{N}\end{array}$ \\
\hline $\begin{array}{l}845 \\
860 \\
866 \\
867 \\
869\end{array}$ & $\begin{array}{r}20 \\
7 \\
7 \\
7 \\
10\end{array}$ & $\begin{array}{l}5 \\
7 \\
7 \\
3 \\
5\end{array}$ & $\begin{array}{l}2 \\
.7 \\
1.5 \\
5 \\
3\end{array}$ & $\begin{array}{l}.015 \\
.03 \\
.1 \\
.15 \\
.15\end{array}$ & $\begin{array}{r}700 \\
700 \\
1,000 \\
1,000 \\
1,000\end{array}$ & $\begin{array}{l}\mathrm{N} \\
\mathrm{N} \\
\mathrm{N} \\
\mathrm{N} \\
\mathrm{N}\end{array}$ & $\begin{array}{r}L \\
N \\
L \\
20 \\
100\end{array}$ & $\begin{array}{l}\mathbf{L} \\
\mathbf{N} \\
\mathbf{N} \\
\mathbf{L}\end{array}$ & $\begin{array}{r}500 \\
70 \\
70 \\
20 \\
50\end{array}$ & $\begin{array}{r}700 \\
>5,000 \\
5,000 \\
2,000 \\
200\end{array}$ & $\begin{array}{r}2,000 \\
L \\
10 \\
L \\
15\end{array}$ & $\begin{array}{l}\mathbf{N} \\
\mathrm{N} \\
\mathrm{N} \\
\mathrm{N} \\
\mathrm{N}\end{array}$ \\
\hline $\begin{array}{l}870 \\
8879 \\
\end{array}$ & $\begin{array}{l}15 \\
20 \\
\end{array}$ & 10 & $\begin{array}{l}1.5 \\
3 \\
\end{array}$ & $\begin{array}{l}.3 \\
.2 \\
\end{array}$ & $\begin{array}{l}1,000 \\
1,500\end{array}$ & $\begin{array}{l}\mathbf{N} \\
\mathbf{N} \\
\end{array}$ & $\begin{array}{r}50 \\
1 \\
\end{array}$ & $\begin{array}{l}\mathbf{N} \\
\mathbf{N}\end{array}$ & $\begin{array}{r}50 \\
150 \\
\end{array}$ & $\begin{array}{r}300 \\
=5,000 \\
\end{array}$ & $\begin{array}{l}15 \\
10 \\
\end{array}$ & $\begin{array}{l}\mathbf{N} \\
\mathbf{N} \\
\end{array}$ \\
\hline
\end{tabular}

9f Contains 500 ppm $\mathrm{Zn}$.

TABLE 8.-Analyses of miscellaneous rock samples

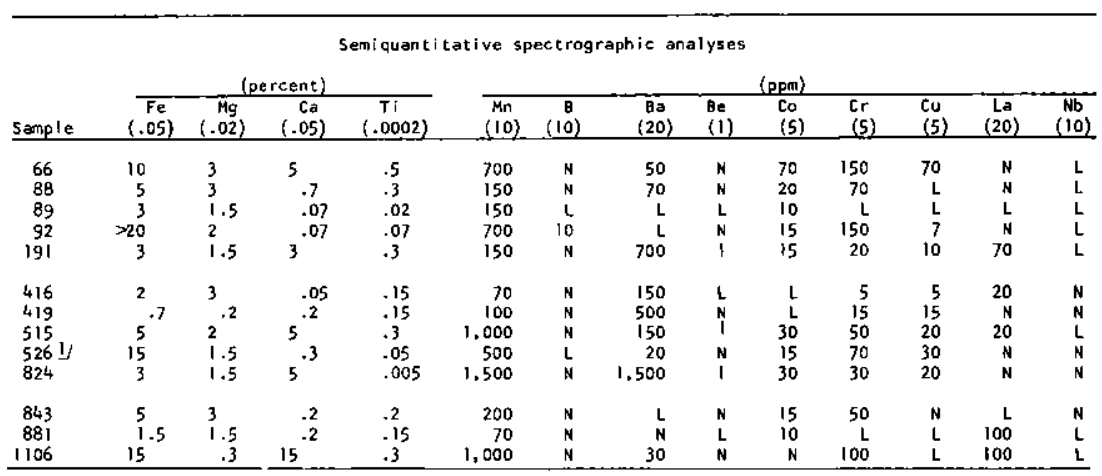

y Contains 200 ppn $2 \pi$. Matrix contains an anthophyllite-like amphibole. 
the Glacier Primitive Area, Fremont County-Continued

Semiquantitative spectrographic analyses--Continued

\begin{tabular}{|c|c|c|c|c|c|c|c|c|c|c|}
\hline Sample & $\begin{array}{c}\mathrm{Nb} \\
(10)\end{array}$ & $\begin{array}{l}\mathrm{Ni} \\
(5)\end{array}$ & $\begin{array}{c}\mathrm{Pb} \\
(10)\end{array}$ & $\begin{array}{c}\text { Sp } \\
S c \\
(5)\end{array}$ & $\frac{2 m) .}{5 r}$ & $\begin{array}{c}v \\
(10)\end{array}$ & $\begin{array}{c}Y \\
(10) \\
\end{array}$ & $\begin{array}{c}2 r \\
(10)\end{array}$ & $\begin{array}{l}\text { Location } \\
\text { Sec-Twp-Rge }\end{array}$ & Remarks \\
\hline \multicolumn{11}{|c|}{ Ultramafic rock samples--Continued } \\
\hline $\begin{array}{l}838 \\
839 \\
840 \\
841 \\
844\end{array}$ & $\begin{array}{r}N \\
L \\
L \\
10 \\
L\end{array}$ & $\begin{array}{r}700 \\
1,500 \\
2,000 \\
1,000 \\
5,000\end{array}$ & $\begin{array}{l}15 \\
\mathrm{~L} \\
\mathrm{~N} \\
\mathrm{~L}\end{array}$ & $\begin{array}{r}5 \\
N \\
7 \\
15 \\
15\end{array}$ & $\begin{array}{r}200 \\
N \\
N \\
N \\
N\end{array}$ & $\begin{array}{l}20 \\
20 \\
20 \\
20 \\
70\end{array}$ & $\begin{array}{r}50 \\
N \\
L \\
30 \\
10\end{array}$ & $\begin{array}{r}\mathrm{L} \\
\mathrm{N} \\
\mathrm{N} \\
\mathrm{N} \\
15\end{array}$ & $\begin{array}{l}35-37-106 \\
35-37-106 \\
35-37-106 \\
35-37-106 \\
26-37-106\end{array}$ & $\begin{array}{l}\text { Tremol ite. } \\
\text { Serpentine vein. } \\
\text { Talc-chlorite. } \\
\text { Tremol ite vein. } \\
\text { Tremolite-serpentine. }\end{array}$ \\
\hline $\begin{array}{l}845 \\
860 \\
866 \\
867 \\
869\end{array}$ & $\begin{array}{r}L \\
L \\
10 \\
L\end{array}$ & $\begin{array}{r}5,000 \\
700 \\
700 \\
50 \\
70\end{array}$ & $\begin{array}{r}10 \\
\mathrm{~L} \\
\mathrm{~N} \\
\mathrm{~L} \\
15\end{array}$ & $\begin{array}{l}\mathrm{L} \\
10 \\
20 \\
50 \\
50\end{array}$ & $\begin{array}{r}N \\
N \\
N \\
N \\
200\end{array}$ & $\begin{array}{r}L \\
50 \\
70 \\
500 \\
150\end{array}$ & $\begin{array}{r}N \\
N \\
L \\
30 \\
20\end{array}$ & $\begin{array}{c}N \\
N \\
10 \\
10 \\
30\end{array}$ & $\begin{array}{l}26-37-106 \\
20-37-105 \\
15-36-106 \\
15-36-106 \\
15-36-106\end{array}$ & $\begin{array}{l}\text { Tremolite crystals. } \\
\text { Tremolite-chlorite. } \\
\text { Do. } \\
\text { Tremolite vein. } \\
\text { Anthophyllite vein. }\end{array}$ \\
\hline $\begin{array}{l}870 \\
887\end{array}$ & $L$ & $\begin{array}{r}100 \\
2,000\end{array}$ & $\begin{array}{r}10 \\
L\end{array}$ & $\begin{array}{l}50 \\
30\end{array}$ & $\begin{array}{l}\mathbf{N} \\
\mathbf{N}\end{array}$ & $\begin{array}{l}150 \\
100\end{array}$ & $\begin{array}{l}30 \\
10\end{array}$ & $\begin{array}{r}150 \\
\mathrm{~N}\end{array}$ & $\begin{array}{l}15-36-106 \\
30-37-106\end{array}$ & $\begin{array}{l}\text { Do. } \\
\text { Tremolite-serpent ine body. }\end{array}$ \\
\hline
\end{tabular}

from she Glacier Primitive Area, Fremont County

Semiquantitative spectrographic analyses--Continued

\begin{tabular}{|c|c|c|c|c|c|c|c|c|c|}
\hline \multirow[b]{2}{*}{ Sample } & \multicolumn{7}{|c|}{ (ppm) } & \multirow[b]{2}{*}{$\begin{array}{c}\text { Location } \\
\text { Sec-Twp-Rge }\end{array}$} & \multirow[b]{2}{*}{ Remarks } \\
\hline & $\begin{array}{l}\mathrm{Ni} \\
(5)\end{array}$ & $\begin{array}{c}\mathrm{Pb} \\
(10)\end{array}$ & $\begin{array}{l}\mathrm{Sc} \\
(5)\end{array}$ & $\begin{array}{c}5 r \\
(100)\end{array}$ & $\begin{array}{c}v \\
(10)\end{array}$ & $\begin{array}{c}\mathbf{Y} \\
(10) \\
\end{array}$ & $\begin{array}{c}\mathrm{Zr} \\
(10) \\
\end{array}$ & & \\
\hline $\begin{array}{r}66 \\
88 \\
89 \\
92 \\
191\end{array}$ & $\begin{array}{l}70 \\
70 \\
30 \\
50 \\
15\end{array}$ & $\begin{array}{r}10 \\
N \\
L \\
L \\
10\end{array}$ & $\begin{array}{r}30 \\
10 \\
L \\
10 \\
10\end{array}$ & $\begin{array}{r}\mathrm{L} \\
100 \\
\mathrm{~N} \\
\mathrm{~N} \\
700\end{array}$ & $\begin{array}{r}200 \\
70 \\
30 \\
50 \\
30\end{array}$ & $\begin{array}{r}20 \\
10 \\
N \\
10 \\
30\end{array}$ & $\begin{array}{r}15 \\
150 \\
50 \\
15 \\
150\end{array}$ & $\begin{array}{r}18-38-105 \\
1-39-107 \\
1-39-107 \\
1-39-107 \\
3-38-107\end{array}$ & $\begin{array}{l}\text { Metadi abase }(?) \\
\text { Dense green rock. } \\
\text { Do. } \\
\text { Taconite float, } \\
\text { Dense green rock. }\end{array}$ \\
\hline $\begin{array}{l}416 \\
419 \\
515 \\
526 \\
824\end{array}$ & $\begin{array}{r}15 \\
15 \\
50 \\
15 \\
150\end{array}$ & $\begin{array}{r}N \\
N \\
10 \\
N \\
L\end{array}$ & $\begin{array}{r}7 \\
\mathrm{~L} \\
30 \\
7 \\
\mathrm{~N}\end{array}$ & $\begin{array}{r}N \\
\mathrm{~L} \\
300 \\
\mathrm{~N} \\
700\end{array}$ & $\begin{array}{r}50 \\
15 \\
100 \\
50 \\
L\end{array}$ & $\begin{array}{r}\mathrm{L} \\
10 \\
15 \\
15 \\
\mathrm{~N}\end{array}$ & $\begin{array}{r}150 \\
20 \\
30 \\
10 \\
\mathrm{~N}\end{array}$ & $\begin{array}{r}9-40-107 \\
7-38-105 \\
12-39-108 \\
12-37-106 \\
19-38-105\end{array}$ & $\begin{array}{l}\text { Do. } \\
\text { Red syenite dike. } \\
\text { Chloritic schist. } \\
\text { Rusty schist. } \\
\text { Anorthosite. }\end{array}$ \\
\hline $\begin{array}{r}843 \\
881 \\
1106\end{array}$ & $\begin{array}{r}50 \\
10 \\
1\end{array}$ & $\begin{array}{r}\mathrm{L} \\
15\end{array}$ & $\begin{array}{r}7 \\
5 \\
30\end{array}$ & $\begin{array}{l}\mathrm{N} \\
\mathrm{N} \\
\mathrm{L}\end{array}$ & $\begin{array}{r}50 \\
20 \\
300\end{array}$ & $\begin{array}{r}30 \\
\mathrm{~N} \\
>200\end{array}$ & $\begin{array}{r}150 \\
20 \\
200\end{array}$ & $\begin{array}{l}34-37-106 \\
33-36-106 \\
14-35-106\end{array}$ & $\begin{array}{l}\text { Albite-chlorite rock. } \\
\text { Albite-chlorite rock. } \\
\text { Pure andradite. }\end{array}$ \\
\hline
\end{tabular}



[Analyses in footnotes: gold by atomic absorption spectrometry, T. A. Roemer and W. H. Ficklin; silver by atomic absorption spectrometry,
497 and 498 by semiquantitative spectrographic analysis. Abbreviations used: biot, biotite;

\begin{tabular}{|c|c|c|c|c|c|c|c|c|c|c|c|c|c|c|c|}
\hline \multicolumn{16}{|c|}{ Semiquantitative spectrographic analyses } \\
\hline & \multicolumn{4}{|c|}{ (Percent) } & \multicolumn{11}{|c|}{ (ppm) } \\
\hline Sample & $\begin{array}{c}\mathrm{Fe} \\
(.05)\end{array}$ & $\begin{array}{c}\mathrm{Mg} \\
(.02)\end{array}$ & $\begin{array}{c}\mathrm{Ca} \\
(.05)\end{array}$ & $\begin{array}{c}\mathrm{Ti} \\
(.002) \\
\end{array}$ & $\begin{array}{c}\text { Mn } \\
(10) \\
\end{array}$ & $\begin{array}{c}\mathrm{Ag} \\
(.5) \\
\end{array}$ & $\begin{array}{c}\text { A5 } \\
(200) \\
\end{array}$ & $\begin{array}{c}8 \\
(10)\end{array}$ & $\begin{array}{r}8 a \\
(20) \\
\end{array}$ & $\begin{array}{l}\text { Be } \\
(1)\end{array}$ & $\begin{array}{l}\text { Co } \\
(5)\end{array}$ & $\begin{array}{l}C r \\
(5)\end{array}$ & $\begin{array}{l}\text { Cu } \\
(5)\end{array}$ & $\begin{array}{c}\text { La } \\
(20)\end{array}$ & $\begin{array}{l}10 \\
(5)\end{array}$ \\
\hline \multicolumn{16}{|c|}{ Breccita samples } \\
\hline $\begin{array}{r}11 \\
91 \\
112 \\
175 \\
402\end{array}$ & $\begin{array}{l}0.3 \\
2 \\
.3 \\
.5\end{array}$ & $\begin{array}{l}0.3 \\
.3 \\
.3 \\
.07 \\
.3\end{array}$ & $\begin{array}{l}0.15 \\
.2 \\
.05 \\
.7 \\
1.5\end{array}$ & $\begin{array}{l}0.02 \\
.15 \\
.015 \\
.03 \\
.1\end{array}$ & $\begin{array}{l}70 \\
50 \\
50 \\
50 \\
70\end{array}$ & $\begin{array}{l}\mathrm{N} \\
\mathrm{N} \\
\mathrm{N} \\
\mathrm{N} \\
\mathrm{N}\end{array}$ & $\begin{array}{l}N \\
N \\
N \\
N \\
N\end{array}$ & $\begin{array}{l}N \\
N \\
N \\
L \\
N\end{array}$ & $\begin{array}{r}50 \\
100 \\
L \\
700 \\
700\end{array}$ & $\begin{array}{l}\mathrm{N} \\
\mathrm{N} \\
\mathrm{L} \\
\mathrm{L} \\
\mathrm{I}\end{array}$ & $\begin{array}{l}\mathrm{N} \\
\mathrm{L} \\
\mathrm{N} \\
\mathrm{N} \\
\mathrm{L}\end{array}$ & $\begin{array}{l}5 \\
\mathrm{~L} \\
\mathrm{~L} \\
7 \\
\mathrm{~L}\end{array}$ & $\begin{array}{r}5 \\
10 \\
L \\
5 \\
10\end{array}$ & $\begin{array}{r}\mathbf{N} \\
70 \\
\mathbf{N} \\
\mathbf{N} \\
70\end{array}$ & $\begin{array}{l}\mathrm{N} \\
\mathrm{N} \\
\mathrm{N} \\
\mathrm{N} \\
\mathrm{N}\end{array}$ \\
\hline $\begin{array}{l}428 \\
435 \\
439 \\
450 \\
461\end{array}$ & $\begin{array}{l}.5 \\
1.5 \\
.15 \\
.3 \\
.3\end{array}$ & $\begin{array}{r}.2 \\
1.5 \\
.2 \\
.5 \\
.2\end{array}$ & $\begin{array}{l}.1 \\
.2 \\
.07 \\
.07 \\
.05\end{array}$ & $\begin{array}{l}.03 \\
.02 \\
.03 \\
.01 \\
.015\end{array}$ & $\begin{array}{r}20 \\
150 \\
10 \\
50 \\
70\end{array}$ & $\begin{array}{l}\mathbf{N} \\
\mathbf{N} \\
\mathbf{N} \\
\mathbf{N} \\
\mathbf{N}\end{array}$ & $\begin{array}{l}\mathrm{N} \\
\mathrm{N} \\
\mathrm{N} \\
\mathrm{N} \\
\mathrm{N}\end{array}$ & $\begin{array}{l}\mathbf{N} \\
\mathbf{N} \\
\mathrm{N} \\
\mathrm{N} \\
\mathrm{N}\end{array}$ & $\begin{array}{r}30 \\
L \\
L \\
L \\
30\end{array}$ & $\begin{array}{l}\mathrm{L} \\
1 \\
\mathrm{~L} \\
1 \\
\mathrm{~N}\end{array}$ & $\begin{array}{l}\text { N } \\
7 \\
\text { N } \\
\text { L } \\
\text { N }\end{array}$ & $\begin{array}{r}L \\
15 \\
10 \\
7 \\
10\end{array}$ & $\begin{array}{r}5 \\
7 \\
\mathrm{~L} \\
15 \\
7\end{array}$ & $\begin{array}{l}\mathrm{N} \\
\mathrm{N} \\
\mathrm{N} \\
\mathrm{N} \\
\mathrm{N}\end{array}$ & $\begin{array}{l}\mathrm{N} \\
\mathrm{N} \\
\mathrm{N} \\
\mathrm{N} \\
\mathrm{N}\end{array}$ \\
\hline $\begin{array}{l}463 \\
464 \\
467 \\
478 \\
479\end{array}$ & $\begin{array}{l}1.5 \\
7 \\
10 \\
10 \\
3\end{array}$ & $\begin{array}{r}.1 \\
1.5 \\
1.5 \\
.3\end{array}$ & $\mathrm{~L}^{.07}$ & $\begin{array}{l}\mathrm{L} \\
.07 \\
.03 \\
.1 \\
.03\end{array}$ & $\begin{array}{r}50 \\
200 \\
150 \\
200 \\
70\end{array}$ & $\begin{array}{l}\mathrm{N} \\
\mathrm{N} \\
\mathrm{N} \\
\mathrm{N} \\
\mathrm{N}\end{array}$ & $\begin{array}{l}\mathrm{N} \\
\mathrm{N} \\
\mathrm{N} \\
\mathrm{N} \\
\mathrm{N}\end{array}$ & $\begin{array}{r}\mathrm{L} \\
10 \\
\mathrm{~L} \\
\mathrm{~N} \\
\mathrm{~N}\end{array}$ & $\begin{array}{l}70 \\
20 \\
30 \\
50 \\
50\end{array}$ & $\begin{array}{c}\mathrm{L} \\
\mathrm{L} \\
1 \\
15 \\
1.5\end{array}$ & $\begin{array}{l}N \\
7 \\
10 \\
15 \\
15\end{array}$ & $\begin{array}{r}150 \\
2,000 \\
1,500 \\
30 \\
20\end{array}$ & $\begin{array}{l}L \\
15 \\
15 \\
15 \\
15\end{array}$ & $\begin{array}{r}\mathrm{N} \\
\mathrm{N} \\
\mathrm{N} \\
\mathrm{N} \\
70\end{array}$ & $\begin{array}{l}\mathrm{N} \\
\mathrm{N} \\
\mathrm{N} \\
\mathrm{N} \\
\mathrm{N}\end{array}$ \\
\hline $\begin{array}{l}480 \\
481 \\
482 \\
483 \\
4911\end{array}$ & $\begin{array}{r}7 \\
5 \\
10 \\
20 \\
1\end{array}$ & $\begin{array}{l}. .1 \\
2 \\
1.5 \\
.07\end{array}$ & $\begin{array}{l}.05 \\
.07 \\
.07 \\
. .3\end{array}$ & $\begin{array}{l}.007 \\
.07 \\
.1 \\
.07 \\
.15\end{array}$ & $\begin{array}{r}70 \\
300 \\
300 \\
150 \\
20\end{array}$ & $\begin{array}{l}\mathbf{N} \\
\mathbf{N} \\
\mathbf{N} \\
\mathrm{N} \\
\mathrm{N}\end{array}$ & $\begin{array}{r}N \\
N \\
N \\
N \\
500\end{array}$ & $\begin{array}{r}N \\
N \\
N \\
10 \\
N\end{array}$ & $\begin{array}{r}\mathrm{L} \\
70 \\
50 \\
100 \\
5,000\end{array}$ & $\begin{array}{l}\mathrm{L} \\
\mathrm{L} \\
\mathrm{L} \\
\mathrm{L} \\
\mathrm{L}\end{array}$ & $\begin{array}{r}L \\
30 \\
20 \\
50 \\
L\end{array}$ & $\begin{array}{l}2 \\
30 \\
70 \\
70 \\
15\end{array}$ & $\begin{array}{r}2 \\
5 \\
15 \\
15 \\
15\end{array}$ & $\begin{array}{c}\mathrm{N} \\
\mathrm{N} \\
\mathrm{N} \\
\mathrm{N} \\
30\end{array}$ & $\begin{array}{r}10 \\
N \\
N \\
N \\
100\end{array}$ \\
\hline $\begin{array}{l}493 \\
494 \\
495 \\
496 \\
497\end{array}$ & $3_{15}^{.7} .1$ & $\begin{array}{l}.3 \\
.05 \\
.3 \\
.7 \\
.7\end{array}$ & $\begin{array}{l}20 \\
20 \\
20 \\
.3 \\
.1\end{array}$ & $\begin{array}{l}.05 \\
.015 \\
.015 \\
.1 \\
.15\end{array}$ & $\begin{array}{r}500 \\
N \\
100 \\
300 \\
300\end{array}$ & $\begin{array}{l}\mathrm{N} \\
\mathrm{N} \\
\mathrm{N} \\
\mathrm{N} \\
\mathrm{N}\end{array}$ & $\begin{array}{r}\mathrm{N} \\
300 \\
\mathrm{~N} \\
\mathrm{~N} \\
300\end{array}$ & $\begin{array}{c}N \\
N \\
N \\
L \\
10\end{array}$ & $\begin{array}{r}150 \\
5,000 \\
20 \\
200 \\
70\end{array}$ & $\begin{array}{l}\mathrm{N} \\
\mathrm{N} \\
\mathrm{N} \\
\mathrm{L} \\
\mathrm{j} .5\end{array}$ & $\begin{array}{r}N \\
N \\
N \\
20 \\
150\end{array}$ & $\begin{array}{r}5 \\
N \\
N \\
100 \\
300\end{array}$ & $\begin{array}{c}\mathrm{L} \\
\mathrm{L} \\
\mathrm{L} \\
15 \\
10\end{array}$ & $\begin{array}{r}\mathrm{N} \\
\mathrm{N} \\
\mathrm{N} \\
\mathrm{N} \\
50\end{array}$ & $\begin{array}{l}\mathrm{N} \\
\mathrm{N} \\
\mathrm{N} \\
\mathrm{N} \\
\mathrm{N}\end{array}$ \\
\hline $\begin{array}{l}498^{3 /} \\
519 \\
520 \\
810 \\
827\end{array}$ & $\begin{array}{c}3 \\
1 \\
15^{-.5}\end{array}$ & $\begin{array}{l}.2 \\
.5 \\
.03 \\
.15 \\
.15\end{array}$ & $\begin{array}{l}.07 \\
.2 \\
.1 \\
.3\end{array}$ & $\begin{array}{l}.03 \\
.1 \\
.07 \\
.03 \\
.1\end{array}$ & $\begin{array}{l}50 \\
70 \\
20 \\
20 \\
30\end{array}$ & $\begin{array}{l}\mathrm{N} \\
\mathrm{N} \\
\mathrm{N} \\
\mathrm{N} \\
\mathrm{N}\end{array}$ & $\begin{array}{r}\mathrm{N} \\
\mathrm{N} \\
\mathrm{N} \\
\mathrm{N} \\
1,500\end{array}$ & $\begin{array}{r}\mathbf{N} \\
\mathbf{N} \\
\mathbf{N} \\
\mathrm{N} \\
10\end{array}$ & $\begin{array}{r}30 \\
30 \\
150 \\
300 \\
5,000\end{array}$ & $\begin{array}{l}\mathrm{L} \\
\mathrm{I} .5 \\
\mathrm{~L} \\
\mathrm{I} \\
\mathrm{L}\end{array}$ & $\begin{array}{l}\mathrm{L} \\
\mathrm{N} \\
\mathrm{N} \\
\mathrm{N} \\
\mathrm{L}\end{array}$ & $\begin{array}{r}15 \\
N \\
5 \\
L \\
20\end{array}$ & $\begin{array}{r}L \\
10 \\
15 \\
5 \\
15\end{array}$ & $\begin{array}{r}N \\
50 \\
20 \\
N \\
L\end{array}$ & $\begin{array}{r}\mathrm{N} \\
\mathrm{N} \\
\mathrm{N} \\
\mathrm{N} \\
50\end{array}$ \\
\hline $\begin{array}{r}828 \\
832 \\
853 \\
1108\end{array}$ & $\begin{array}{l}3 \\
1.5 \\
.2\end{array}$ & $1^{.03}$ & $\begin{array}{l}10 \\
.15 \\
.05 \\
.2\end{array}$ & $\begin{array}{l}.02 \\
.1 \\
.01 \\
.15\end{array}$ & $\begin{array}{r}10 \\
100 \\
15 \\
300\end{array}$ & $\begin{array}{l}\mathrm{N} \\
\mathrm{N} \\
\mathrm{N} \\
\mathrm{N}\end{array}$ & $\begin{array}{l}\mathrm{L} \\
\mathbf{N} \\
\mathrm{N} \\
\mathrm{N}\end{array}$ & $\begin{array}{l}\mathrm{N} \\
\mathrm{N} \\
\mathrm{N} \\
\mathrm{N}\end{array}$ & $\begin{array}{r}100 \\
N \\
20\end{array}$ & $\begin{array}{l}L \\
L \\
L \\
L\end{array}$ & $\begin{array}{r}N \\
10 \\
N \\
1\end{array}$ & $\begin{array}{r}L \\
10 \\
L \\
30\end{array}$ & $\begin{array}{r}10 \\
N \\
5 \\
5\end{array}$ & $\begin{array}{r}\mathbf{N} \\
\mathbf{N} \\
\mathbf{N} \\
20\end{array}$ & $\begin{array}{l}\mathrm{N} \\
\mathrm{N} \\
\mathrm{N} \\
\mathrm{N}\end{array}$ \\
\hline \multicolumn{16}{|c|}{ Vein samples } \\
\hline $\begin{array}{l}22 \\
30 \\
36 \\
39 \\
40\end{array}$ & $\begin{array}{r}10 \\
5 \\
3 \\
5 \\
10\end{array}$ & $\begin{array}{l}1.5 \\
\mathrm{I}^{.03} \\
.2\end{array}$ & $\begin{array}{l}0.5 \\
7 \\
i \\
.2 \\
.05\end{array}$ & $\begin{array}{l}0.05 \\
.15 \\
.3 \\
.03 \\
.15\end{array}$ & $\begin{array}{r}700 \\
300 \\
300 \\
100 \\
50\end{array}$ & $\begin{array}{c}N \\
N \\
N \\
5 \\
15\end{array}$ & $\begin{array}{l}\mathrm{N} \\
\mathrm{N} \\
\mathrm{N} \\
\mathrm{N} \\
\mathrm{N}\end{array}$ & $\begin{array}{r}15 \\
\mathrm{~N} \\
\mathrm{~L} \\
\mathrm{~N} \\
\mathrm{~L}\end{array}$ & $\begin{array}{r}50 \\
300 \\
300 \\
200 \\
30\end{array}$ & $\begin{array}{l}\mathrm{N} \\
\mathrm{L} \\
\mathrm{L} \\
\mathrm{I} \\
\mathrm{L}\end{array}$ & $\begin{array}{r}7 \\
5 \\
15 \\
N \\
N\end{array}$ & $\begin{array}{r}200 \\
7 \\
150 \\
20 \\
30\end{array}$ & $\begin{array}{r}30 \\
5 \\
300 \\
50 \\
100\end{array}$ & $\begin{array}{r}N \\
100 \\
20 \\
50 \\
L\end{array}$ & $\begin{array}{l}\mathbf{N} \\
\mathbf{N} \\
\mathrm{N} \\
\mathrm{N} \\
\mathrm{N}\end{array}$ \\
\hline $\begin{array}{l}43 \\
53 \\
54 \\
56 \\
57\end{array}$ & $\begin{array}{r}10 \\
20 \\
15 \\
3 \\
20\end{array}$ & $\begin{array}{l}.7 \\
.07 \\
.05 \\
.5 \\
.7\end{array}$ & $\begin{array}{l}.3 \\
.07 \\
.07 \\
.05\end{array}$ & $\begin{array}{l}.15 \\
.005 \\
.015 \\
.003 \\
.1\end{array}$ & $\begin{array}{l}100 \\
150 \\
300 \\
150 \\
500\end{array}$ & $\begin{array}{l}1 \\
N \\
N \\
N \\
N\end{array}$ & $\begin{array}{l}\mathrm{N} \\
\mathrm{N} \\
\mathrm{N} \\
\mathrm{N} \\
\mathrm{N}\end{array}$ & $\begin{array}{r}\mathrm{L} \\
10 \\
\mathrm{~L} \\
\mathrm{~N} \\
10\end{array}$ & $\begin{array}{r}100 \\
\mathrm{~L} \\
70 \\
\mathrm{~L} \\
70\end{array}$ & $\begin{array}{l}L \\
L \\
3 \\
L \\
L\end{array}$ & $\begin{array}{l}N \\
15 \\
15 \\
5 \\
15\end{array}$ & $\begin{array}{r}20 \\
7 \\
15 \\
L \\
150\end{array}$ & $\begin{array}{r}70 \\
2 \\
1,000 \\
5 \\
15\end{array}$ & $\begin{array}{l}\mathrm{L} \\
\mathrm{L} \\
N \\
N \\
\mathrm{~L}\end{array}$ & $\begin{array}{l}\mathrm{N} \\
\mathbf{N} \\
\mathrm{N} \\
\mathrm{N} \\
\mathrm{N}\end{array}$ \\
\hline $\begin{array}{c}59 \\
64 \\
79 \\
108 \\
1164\end{array}$ & $\begin{array}{l}3 \\
7 \\
10 \\
1.5 \\
2\end{array}$ & $\begin{array}{l}.5 \\
.3 \\
.1 \\
.15 \\
.2\end{array}$ & $\begin{array}{l}.05 \\
.7 \\
.15 \\
.5\end{array}$ & $\begin{array}{l}.07 \\
.2 \\
.1 \\
.03 \\
.2\end{array}$ & $\begin{array}{r}100 \\
100 \\
20 \\
50 \\
150\end{array}$ & $\begin{array}{l}\text { N } \\
\text { N } \\
\text { L } \\
0.5 \\
5\end{array}$ & $\begin{array}{l}\mathbf{N} \\
\mathbf{N} \\
\mathbf{N} \\
\mathrm{N} \\
\mathrm{N}\end{array}$ & $\begin{array}{c}\text { N } \\
L \\
10 \\
L \\
N\end{array}$ & $\begin{array}{r}300 \\
200 \\
200 \\
70 \\
150\end{array}$ & $\begin{array}{l}\mathrm{N} \\
\mathrm{L} \\
\mathrm{L} \\
1 \\
\mathrm{~L}\end{array}$ & $\begin{array}{l}\mathrm{N} \\
\mathrm{N} \\
\mathrm{N} \\
\mathrm{N} \\
\mathrm{N}\end{array}$ & $\begin{array}{r}70 \\
50 \\
150 \\
50 \\
5\end{array}$ & $\begin{array}{r}50 \\
100 \\
150 \\
30 \\
20\end{array}$ & $\begin{array}{r}70 \\
20 \\
\mathrm{~N} \\
\mathrm{~N} \\
30\end{array}$ & $\begin{array}{l}N \\
N \\
N \\
5 \\
N\end{array}$ \\
\hline $\begin{array}{l}172 \\
181 \\
187 \\
196 \\
413\end{array}$ & $\begin{array}{c}3 \\
>20 \\
5_{2}^{.5}\end{array}$ & $\begin{array}{r}\mathrm{L} \\
.1 \\
.3 \\
1.5 \\
.7\end{array}$ & $\begin{array}{c}\mathrm{L} \\
\mathrm{L} \\
10 \\
I^{\prime} \\
.07\end{array}$ & $\begin{array}{l}.007 \\
.03 \\
.02 \\
.7 \\
.03\end{array}$ & $\begin{array}{r}50 \\
50 \\
500 \\
150 \\
150\end{array}$ & $\begin{array}{l}\mathbf{N} \\
\mathbf{N} \\
\mathbf{N} \\
\mathbf{N} \\
\mathbf{N}\end{array}$ & $\begin{array}{l}\mathbf{N} \\
\mathbf{N} \\
\mathrm{N} \\
\mathrm{N} \\
\mathrm{N}\end{array}$ & $\begin{array}{r}\mathbf{N} \\
30 \\
\mathbf{N} \\
\mathbf{N} \\
\mathbf{N}\end{array}$ & $\begin{array}{r}30 \\
30 \\
N \\
100 \\
30\end{array}$ & $\begin{array}{l}\mathrm{N} \\
\mathrm{L} \\
7 \\
1 \\
\mathrm{~L}\end{array}$ & $\begin{array}{r}N \\
100 \\
300 \\
30 \\
15\end{array}$ & $\begin{array}{r}\mathrm{L} \\
5 \\
20 \\
300 \\
5\end{array}$ & $\begin{array}{l}5 \\
\mathrm{~L} \\
15 \\
15 \\
10\end{array}$ & $\begin{array}{r}\mathrm{L} \\
\mathrm{N} \\
, 000 \\
\mathrm{~L} \\
70\end{array}$ & $\begin{array}{l}\mathbf{N} \\
\mathbf{N} \\
\mathbf{N} \\
\mathbf{N} \\
\mathbf{N}\end{array}$ \\
\hline
\end{tabular}

If Contains 0.016 percent $U$.

2f Contains about 0.2 percent $U$. 
Z. C. Stephenson and J. V. Desmond; uranium of sample 491 by paper chromatography, R. L. Miller; uranium of samples bx, breccia; Fe st, iron stained; bem, hematite; mag, magnetite; py, pyrite; qtz, quartz]

Semiquantitative spectrographic analyses--Continued

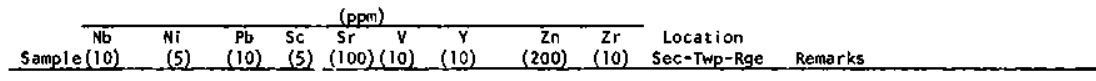

\section{Breccia samples}

\begin{tabular}{|c|c|c|c|c|c|c|}
\hline $\begin{array}{r}11 \\
91 \\
112 \\
175 \\
402\end{array}$ & $\begin{array}{l}\text { L } \\
\text { L } \\
\text { L } \\
\text { L } \\
\text { L }\end{array}$ & $\begin{array}{r}2 \\
50 \\
5 \\
2 \\
3\end{array}$ & $\begin{array}{c}N \\
N \\
N \\
10 \\
50\end{array}$ & $\begin{array}{l}\text { N } \\
N \\
L \\
N \\
L\end{array}$ & $\begin{array}{r}\mathbf{N} \\
\mathbf{N} \\
\mathbf{N} \\
100 \\
\mathbf{L}\end{array}$ & $\begin{array}{r}\mathrm{L} \\
10 \\
\mathrm{~L} \\
50 \\
10\end{array}$ \\
\hline $\begin{array}{l}428 \\
435 \\
439 \\
450 \\
461\end{array}$ & $\begin{array}{l}N \\
L \\
L \\
\text { L }\end{array}$ & $\begin{array}{r}5 \\
10 \\
L \\
L \\
7\end{array}$ & $\begin{array}{l}\mathrm{N} \\
\mathrm{N} \\
\mathrm{N} \\
\mathrm{N} \\
\mathrm{N}\end{array}$ & $\begin{array}{l}\text { N } \\
\text { L } \\
\text { L } \\
N \\
N\end{array}$ & $\begin{array}{l}N \\
N \\
N \\
N \\
N\end{array}$ & $\begin{array}{r}10 \\
30 \\
1 \\
L \\
10\end{array}$ \\
\hline $\begin{array}{l}463 \\
464 \\
467 \\
478 \\
479\end{array}$ & $\begin{array}{l}\mathbf{L} \\
\mathrm{L} \\
\mathrm{L} \\
\mathrm{N} \\
\mathrm{N}\end{array}$ & $\begin{array}{r}\mathrm{L} \\
300 \\
200 \\
70 \\
20\end{array}$ & $\begin{array}{l}\mathbf{N} \\
\mathrm{N} \\
\mathrm{N} \\
\mathrm{L} \\
\mathrm{N}\end{array}$ & $\begin{array}{r}\text { N } \\
5 \\
7 \\
15 \\
\text { L }\end{array}$ & $\begin{array}{l}N \\
N \\
N \\
N \\
N\end{array}$ & $\begin{array}{l}15 \\
70 \\
70 \\
70 \\
30\end{array}$ \\
\hline $\begin{array}{l}480 \\
481 \\
482 \\
483 \\
491\end{array}$ & $\begin{array}{l}\mathbf{L} \\
\mathbf{L} \\
\mathbf{L} \\
\mathbf{L} \\
\mathbf{L}\end{array}$ & $\begin{array}{r}1 \\
70 \\
70 \\
70 \\
15\end{array}$ & $\begin{array}{r}\mathbf{N} \\
\mathrm{L} \\
\mathbf{N} \\
\mathbf{N} \\
30\end{array}$ & $\begin{array}{r}L \\
30 \\
15 \\
10 \\
7\end{array}$ & $\begin{array}{r}\mathbf{N} \\
\mathbf{N} \\
\mathrm{N} \\
\mathrm{L} \\
100\end{array}$ & $\begin{array}{r}50 \\
50 \\
70 \\
50 \\
300\end{array}$ \\
\hline $\begin{array}{l}493 \\
494 \\
495 \\
496 \\
497\end{array}$ & $\begin{array}{l}\text { N } \\
N \\
N \\
\text { L } \\
N\end{array}$ & $\begin{array}{r}\mathbf{N} \\
\mathbf{L} \\
\mathbf{N} \\
70 \\
200\end{array}$ & $\begin{array}{r}\mathrm{N} \\
\mathrm{N} \\
\mathrm{N} \\
\mathrm{N} \\
1,500\end{array}$ & $\begin{array}{l}\mathrm{L} \\
\mathrm{L} \\
N \\
10 \\
20\end{array}$ & $\begin{array}{r}300 \\
100 \\
500 \\
\mathrm{~N} \\
\mathrm{~N}\end{array}$ & $\begin{array}{r}L \\
L \\
10 \\
50 \\
300\end{array}$ \\
\hline $\begin{array}{l}498 \\
519 \\
520 \\
810 \\
827\end{array}$ & $\begin{array}{l}N \\
L \\
L \\
N \\
L\end{array}$ & $\begin{array}{r}\mathrm{L} \\
\mathrm{L} \\
\mathrm{N} \\
7 \\
20\end{array}$ & $\begin{array}{l}15 \\
\mathrm{~L} \\
\mathrm{~N} \\
\mathrm{~N} \\
\mathrm{~N}\end{array}$ & $\begin{array}{l}\mathrm{L} \\
5 \\
\mathrm{~N} \\
\mathrm{~N} \\
\mathrm{~N}\end{array}$ & $\begin{array}{r}\text { N } \\
150 \\
L \\
N \\
\text { N }\end{array}$ & $\begin{array}{r}70 \\
30 \\
15 \\
1 \\
30\end{array}$ \\
\hline $\begin{array}{r}828 \\
832 \\
853 \\
1108\end{array}$ & $\begin{array}{l}\text { L } \\
\text { L } \\
\text { N } \\
\text { L }\end{array}$ & $\begin{array}{r}\mathbf{N} \\
15 \\
7 \\
30\end{array}$ & $\begin{array}{c}\mathrm{N} \\
\mathrm{L} \\
\mathrm{N}\end{array}$ & $\begin{array}{l}\text { N } \\
\text { L } \\
\text { N } \\
7\end{array}$ & $\begin{array}{l}\mathrm{N} \\
\mathrm{N} \\
\mathrm{N} \\
\mathrm{N}\end{array}$ & $\begin{array}{r}L \\
30 \\
L \\
30\end{array}$ \\
\hline
\end{tabular}

\section{Vein samples}

$\begin{array}{rrrrrrrrrrr}22 & \text { N } & 70 & \mathrm{~L} & 10 & \mathrm{~N} & 30 & 10 & \mathrm{~L} & 30 & 34-38-106 \\ 30 & \mathrm{~L} & 2 & 10 & 5 & 700 & 70 & 20 & \mathrm{~N} & 30 & 27-38-106 \\ 36 & \mathrm{~L} & 70 & 15 & 15 & 150 & 70 & 15 & \mathrm{~N} & 150 & 13-38-106 \\ 39 & \mathrm{~L} & \mathrm{~L} & 500 & \mathrm{~N} & \mathrm{~N} & 30 & 50 & 10,000 & 150 & 11-38-106 \\ 40 & \mathrm{~L} & \mathrm{~L} & 150 & \mathrm{~L} & \mathrm{~N} & 50 & \mathrm{~L} & 700 & 150 & 11-38-106 \\ 43 & \mathrm{~L} & \mathrm{~L} & 10 & 7 & \mathrm{~N} & 70 & 30 & \mathrm{~N} & 700 & 7-37-106 \\ 53 & \mathrm{~L} & \mathrm{~L} & 10 & \mathrm{~L} & \mathrm{~N} & 30 & 15 & \mathrm{~N} & \mathrm{~N} & 29-39-106 \\ 54 & \mathrm{~L} & 15 & 10 & \mathrm{~L} & \mathrm{~N} & 200 & 15 & \mathrm{~N} & \mathrm{~N} & 29-39-106 \\ 56 & \mathrm{~L} & \mathrm{~L} & \mathrm{~L} & \mathrm{~N} & \mathrm{~N} & 15 & 15 & \mathrm{~N} & \mathrm{~N} & 29-39-106 \\ 57 & \mathrm{~L} & 30 & 10 & 10 & \mathrm{~L} & 30 & 30 & \mathrm{~N} & 50 & 29-39-106 \\ & & & & & & & & & & \\ 59 & \mathrm{~L} & 20 & 10 & 5 & \mathrm{~N} & 30 & 20 & \mathrm{~N} & 100 & 32-39-106 \\ 65 & 20 & \mathrm{~L} & 20 & 7 & \mathrm{~N} & 70 & 100 & \mathrm{~N} & 200 & 28-39-106 \\ 79 & \mathrm{~L} & \mathrm{~L} & 10 & \mathrm{~L} & \mathrm{~N} & 50 & \mathrm{~N} & \mathrm{~N} & 20 & 33-39-106 \\ 13 & \mathrm{~L} & \mathrm{~L} & 150 & \mathrm{~L} & \mathrm{~N} & 20 & \mathrm{~L} & \mathrm{~N} & 150 & 23-38-106 \\ 116 & \mathrm{I} & \mathrm{L} & 1,500 & 5 & \mathrm{~N} & 30 & 70 & 300 & 300 & 11-38-106 \\ & & & & & & & & & & \\ 172 & \mathrm{~N} & \mathrm{~L} & \mathrm{~N} & \mathrm{~N} & \mathrm{~N} & 30 & \mathrm{~N} & \mathrm{~N} & \mathrm{~N} & 19-40-106 \\ 181 & \mathrm{~L} & \mathrm{~L} & 15 & 15 & \mathrm{~N} & 70 & \mathrm{~N} & \mathrm{~N} & \mathrm{~N} & 2-41-107 \\ 187 & \mathrm{~N} & 70 & \mathrm{~N} & \mathrm{~N} & \mathrm{~N} & \mathrm{~L} & >200 & \mathrm{~N} & 30 & 32-41-107 \\ 196 & \mathrm{I} & \mathrm{I} & 10 & 15 & \mathrm{~N} & 150 & 50 & \mathrm{~N} & 500 & 7-37-106 \\ 413 & \mathrm{~L} & 15 & \mathrm{~L} & \mathrm{~L} & \mathrm{~N} & 15 & 10 & \mathrm{~N} & 20 & 35-41-107\end{array}$

Qtz-chlorite bx.

Purplish atz bx.

Qtz-chlorite bx.

Fe st fault bx.

Barren granite bx.

Qtz-chlorite bx.

Do.

Do.

Do.

Qtz-chlorite bx; float.

Bx from prospect cut.

Do

Do.

Bx from mine dump

Do.

Do.

Do.

Do

Do.

Bx from prospect pit.

$8 x$ in Ross Lakes fault

Bx from mine dump.

Bx near faults.

$B x$ from mine dump.

Do.

Do.

Bx from Jakeys Fork fault.

Do.

Bx from Jakeys Fork fault.

Bx from Ross Lakes fault.

22-41-107

5-36-106

$1-36-106$

Do.

Qtz-chlorite bx.

Do.

Do.

fe st biot in fault.

Qtz-epidote vein.

Fe st faulted gneiss.

Fy-gossan vein.

Gossan vein.

Fe st gneiss; float.

Qtz-specularite float.

Gossan; float.

Qtz-specularite float.

$$
\text { Do. }
$$

Gossan from fault.

Gossan vein.

D.

Fe st biot in fault.

Sulfide vein.

Qtz-specularite vein. Do.

Fe st zone.

Pyritic zone.

Vein qtz in fault.

3) U looked for but not detected.

4) Contains $15 \mathrm{ppm} \mathrm{Bi}$. 


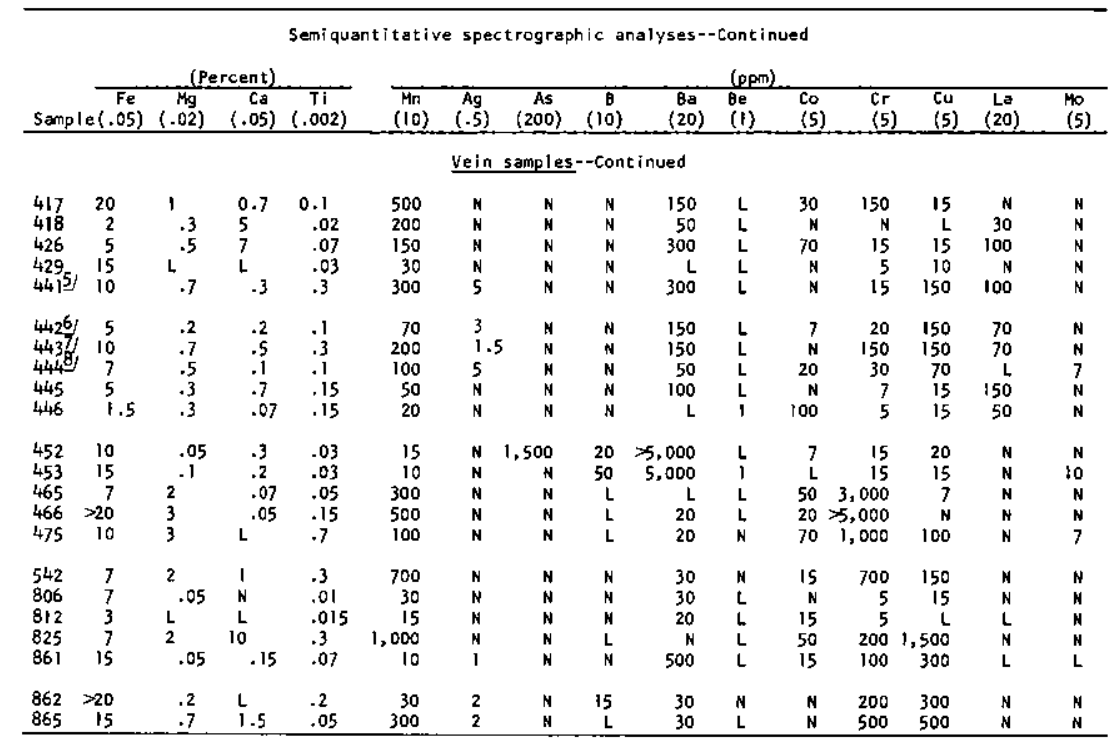

5) Contains $8.0 \mathrm{ppm} \mathrm{Ag}$ and $0.3 \mathrm{ppm} \mathrm{Au}$.

6. Contains $5.2 \mathrm{ppm} \mathrm{Ag}$ and $0.08 \mathrm{ppm} \mathrm{Au}$. 
Semiquantitative spectrographic analyses--Continued

\begin{tabular}{|c|c|c|c|c|c|c|c|c|c|}
\hline \multirow{2}{*}{$\begin{array}{c}\mathrm{Nb} \\
\text { Sample }(10)\end{array}$} & \multicolumn{6}{|c|}{ (ppm) } & \multirow[b]{2}{*}{$\begin{array}{c}\mathrm{Zr} \\
(10)\end{array}$} & \multirow[b]{2}{*}{$\begin{array}{c}\text { Locat ion } \\
\text { Sec-Twp-Rge }\end{array}$} & \multirow[b]{2}{*}{ Remarks } \\
\hline & $\begin{array}{l}\mathrm{Ni} \\
\text { (5) }\end{array}$ & $\begin{array}{c}\mathrm{Pb} \\
(10)\end{array}$ & $\begin{array}{l}5 c \\
\text { (5) }\end{array}$ & $\begin{array}{cc}\mathrm{Sr} & \\
(100)(10)\end{array}$ & $\begin{array}{c}Y \\
(10)\end{array}$ & $\begin{array}{r}2 n \\
(200)\end{array}$ & & & \\
\hline
\end{tabular}

\begin{tabular}{|c|c|c|c|c|c|c|c|c|c|c|c|}
\hline $\begin{array}{l}417 \\
418 \\
426 \\
429 \\
441\end{array}$ & $\begin{array}{r}N \\
N \\
L \\
L \\
10\end{array}$ & $\begin{array}{r}30 \\
10 \\
5 \\
\mathrm{~L} \\
\mathrm{~N}\end{array}$ & $\begin{array}{r}10 \\
N \\
15 \\
L \\
500\end{array}$ & $\begin{array}{r}10 \\
5 \\
10 \\
L \\
7\end{array}$ & $\begin{array}{r}N \\
500 \\
700 \\
N \\
N\end{array}$ & $\begin{array}{r}70 \\
70 \\
70 \\
100 \\
70\end{array}$ & $\begin{array}{r}10 \\
15 \\
15 \\
N \\
50\end{array}$ & 1,000 & $\begin{array}{r}20 \\
N \\
100 \\
30 \\
300\end{array}$ & $\begin{array}{r}9-40-107 \\
4-40-107 \\
35-39-107 \\
36-39-107 \\
11-38-107\end{array}$ & $\begin{array}{l}\text { Qtz-specularite float. } \\
\text { Qtz-epidote vein. } \\
\quad \text { Do. } \\
\text { Qtz-specularite vein } \\
5-f t \text { channel sample. }\end{array}$ \\
\hline $\begin{array}{l}442 \\
443 \\
444 \\
445 \\
446\end{array}$ & $\begin{array}{r}\mathrm{L} \\
10 \\
\mathrm{~L} \\
\mathrm{~L} \\
\mathrm{~L}\end{array}$ & $\begin{array}{r}\mathrm{L} \\
\mathrm{L} \\
15 \\
\mathrm{~L} \\
5\end{array}$ & $\begin{array}{r}700 \\
300 \\
150 \\
30 \\
100\end{array}$ & $\begin{array}{l}\mathrm{L} \\
7 \\
5 \\
7 \\
\mathrm{~L}\end{array}$ & $\begin{array}{l}N \\
N \\
N \\
L \\
N\end{array}$ & $\begin{array}{l}30 \\
50 \\
30 \\
70 \\
10\end{array}$ & $\begin{array}{r}15 \\
150 \\
10 \\
15 \\
L\end{array}$ & $\begin{array}{r}3,000 \\
700 \\
3,000 \\
N \\
N\end{array}$ & $\begin{array}{l}200 \\
150 \\
300 \\
150 \\
150\end{array}$ & $\begin{array}{l}11-38-107 \\
11-38-107 \\
11-38-107 \\
29-39-106 \\
19-39-106\end{array}$ & $\begin{array}{l}\text { 4-ft channel sample. } \\
\text { Do. } \\
\text { 3-ft channel sample. } \\
\text { Mag-hem-qtz vein. } \\
\text { Py-gossan vein. }\end{array}$ \\
\hline $\begin{array}{l}452 \\
453 \\
465 \\
466 \\
475\end{array}$ & $\begin{array}{l}\mathbf{L} \\
\mathbf{L} \\
\mathbf{L} \\
\mathbf{L} \\
\mathbf{L}\end{array}$ & $\begin{array}{r}50 \\
15 \\
1,000 \\
1,000 \\
300\end{array}$ & $\begin{array}{r}10 \\
10 \\
N \\
N \\
N\end{array}$ & $\begin{array}{r}L \\
L \\
5 \\
20 \\
10\end{array}$ & $\begin{array}{r}300 \\
150 \\
N \\
N \\
N\end{array}$ & $\begin{array}{r}\mathrm{L} \\
\mathrm{L} \\
50 \\
150 \\
150\end{array}$ & $\begin{array}{r}15 \\
L \\
L \\
15 \\
N\end{array}$ & $\begin{array}{l}\mathbf{N} \\
\mathbf{N} \\
\mathbf{N} \\
\mathbf{N} \\
\mathbf{N}\end{array}$ & $\begin{array}{r}10 \\
L \\
N \\
30 \\
70\end{array}$ & $\begin{array}{r}26-41-107 \\
26-41-107 \\
7-40-107 \\
7-40-107 \\
18-40-107\end{array}$ & $\begin{array}{l}\text { Gossan from fault. } \\
\text { Do. } \\
\text { Chlorite-py vein. } \\
\text { Mag vein in bx. } \\
\text { Gossan in biot schist. }\end{array}$ \\
\hline $\begin{array}{l}542 \\
806 \\
812 \\
825 \\
861\end{array}$ & $\begin{array}{l}\mathrm{L} \\
\mathrm{L} \\
\mathrm{L} \\
\mathrm{L} \\
\mathrm{L}\end{array}$ & $\begin{array}{r}70 \\
N \\
\mathrm{~L} \\
70 \\
7\end{array}$ & $\begin{array}{c}N \\
N \\
N \\
L \\
10\end{array}$ & $\begin{array}{r}30 \\
N \\
N \\
30 \\
L\end{array}$ & $\begin{array}{r}\mathbf{N} \\
\mathbf{N} \\
\mathbf{N} \\
300 \\
\mathbf{N}\end{array}$ & $\begin{array}{r}150 \\
70 \\
10 \\
150 \\
50\end{array}$ & $\begin{array}{r}10 \\
N \\
N \\
10 \\
N\end{array}$ & $\begin{array}{l}\mathbf{N} \\
\mathbf{N} \\
\mathbf{N} \\
\mathbf{N} \\
\mathbf{N}\end{array}$ & $\begin{array}{r}30 \\
\mathrm{~N} \\
\mathrm{~L} \\
15 \\
200\end{array}$ & $\begin{array}{r}7-37-105 \\
33-41-107 \\
28-41-107 \\
19-38-105 \\
29-37-105\end{array}$ & $\begin{array}{l}\text { Gossan-py vein. } \\
\text { Qtz-hem vein. } \\
\text { Qtz-specularite vein. } \\
\text { Qtz-epidote-py vein. } \\
\text { Gossan vein. }\end{array}$ \\
\hline $\begin{array}{l}862 \\
865\end{array}$ & $L$ & 20 & $\begin{array}{r}200 \\
10\end{array}$ & $\begin{array}{l}\mathrm{L} \\
15\end{array}$ & $\begin{array}{l}\mathbf{N} \\
\mathrm{N}\end{array}$ & $\begin{array}{r}100 \\
70\end{array}$ & $\mathrm{~L}$ & $\begin{array}{l}\mathbf{N} \\
\mathbf{N}\end{array}$ & $\begin{array}{r}150 \\
10\end{array}$ & $\begin{array}{l}29-37-105 \\
10-36=106\end{array}$ & $\begin{array}{l}\text { Do. } \\
\text { Do. }\end{array}$ \\
\hline
\end{tabular}

y Contains $2.4 \mathrm{ppm} \mathrm{Ag,} 0.08 \mathrm{ppm} \mathrm{Au}$, and $15 \mathrm{ppm} \mathrm{Sn}$.

8f Contains $9.2 \mathrm{ppm} \mathrm{Ag}$ and $0.06 \mathrm{ppm} \mathrm{Au}$. 
TABLE 10,-Analyses of stream-sediment and soil samples

[CxHM analyses, A, ]. Toevs. Townships marked

Semiquantitative spectrographic analyses

\begin{tabular}{|c|c|c|c|c|c|c|c|c|c|c|c|c|c|c|c|}
\hline \multirow[b]{2}{*}{ Sample } & \multicolumn{4}{|c|}{ (percent) } & \multicolumn{10}{|c|}{ (ppm) } & \\
\hline & $\begin{array}{c}\mathrm{Fe} \\
(.05)\end{array}$ & $\begin{array}{c}\mathrm{Mg} \\
(.02)\end{array}$ & $\begin{array}{c}\mathrm{Ca} \\
(.05)\end{array}$ & $\begin{array}{c}\mathrm{Ti} \\
(.002)\end{array}$ & $\begin{array}{c}\text { Mn } \\
\text { (10) }\end{array}$ & $\begin{array}{c}8 \\
(10)\end{array}$ & $\begin{array}{c}\text { Ba } \\
\text { (20) }\end{array}$ & $\begin{array}{l}\mathbf{B e} \\
\text { (1) }\end{array}$ & $\begin{array}{l}\text { Co } \\
\text { (5) }\end{array}$ & $\begin{array}{l}\mathrm{Cr} \\
\text { (5) }\end{array}$ & $\begin{array}{l}\mathrm{Cu} \\
\text { (5) }\end{array}$ & $\begin{array}{c}\text { La } \\
\text { (20) }\end{array}$ & $\begin{array}{l}\text { Mo } \\
\text { (5) }\end{array}$ & $\begin{array}{c}\mathrm{Nb} \\
(10)\end{array}$ & $\begin{array}{l}\mathrm{Ni} \\
(5)\end{array}$ \\
\hline
\end{tabular}

Soil samples

\begin{tabular}{|c|c|c|c|c|c|c|c|c|c|c|c|c|c|c|c|}
\hline $\begin{array}{l}206 \\
207 \\
216 \\
221 \\
223\end{array}$ & $\begin{array}{l}3 \\
2 \\
3 \\
3 \\
2\end{array}$ & $\begin{array}{r}1.5 \\
.7 \\
.7 \\
1.5 \\
.7\end{array}$ & $\begin{array}{l}1 \\
1 \\
.5 \\
1.5 \\
.7\end{array}$ & $\begin{array}{l}0.2 \\
.2 \\
.15 \\
.2 \\
.15\end{array}$ & $\begin{array}{l}200 \\
200 \\
300 \\
500 \\
300\end{array}$ & $\begin{array}{r}\mathbf{N} \\
\mathbf{L} \\
\mathrm{L} \\
\mathrm{L} \\
50\end{array}$ & $\begin{array}{l}150 \\
300 \\
300 \\
300 \\
700\end{array}$ & $\begin{array}{l}\mathbf{L} \\
1 \\
1 \\
1.5 \\
1\end{array}$ & $\begin{array}{l}15 \\
10 \\
15 \\
15 \\
10\end{array}$ & $\begin{array}{r}70 \\
30 \\
30 \\
100 \\
30\end{array}$ & $\begin{array}{r}15 \\
10 \\
7 \\
30 \\
10\end{array}$ & $\begin{array}{l}70 \\
50 \\
70 \\
50 \\
30\end{array}$ & $\begin{array}{l}\mathbf{N} \\
\mathbf{N} \\
\mathbf{N} \\
\mathbf{N} \\
\mathbf{N}\end{array}$ & $\begin{array}{l}\mathrm{L} \\
\mathrm{L} \\
\mathrm{L} \\
\mathrm{L} \\
\mathrm{L}\end{array}$ & $\begin{array}{l}70 \\
30 \\
15 \\
50 \\
15\end{array}$ \\
\hline $\begin{array}{l}225 \\
226 \\
227 \\
236 \\
302\end{array}$ & $\begin{array}{l}3 \\
1.5 \\
2 \\
1.5 \\
2\end{array}$ & $\begin{array}{l}2 \\
2 \\
3 \\
.7 \\
.7\end{array}$ & $\begin{array}{l}2 \\
2 \\
2 \\
1^{.5}\end{array}$ & $\begin{array}{l}.2 \\
.15 \\
.15 \\
.15 \\
.15\end{array}$ & $\begin{array}{l}500 \\
300 \\
300 \\
200 \\
500\end{array}$ & $\begin{array}{r}30 \\
30 \\
30 \\
L \\
30\end{array}$ & $\begin{array}{l}700 \\
500 \\
500 \\
200 \\
700\end{array}$ & $\begin{array}{l}1 \\
1 \\
1 \\
1 \\
1\end{array}$ & $\begin{array}{r}10 \\
5 \\
7 \\
7 \\
\text { L }\end{array}$ & $\begin{array}{l}50 \\
50 \\
50 \\
20 \\
30\end{array}$ & $\begin{array}{r}15 \\
10 \\
10 \\
7 \\
7\end{array}$ & $\begin{array}{l}30 \\
20 \\
30 \\
50 \\
20\end{array}$ & $\begin{array}{l}\mathbf{N} \\
\mathbf{N} \\
\mathbf{N} \\
\mathbf{N} \\
\mathbf{N}\end{array}$ & $\begin{array}{l}\mathrm{L} \\
\mathrm{L} \\
\mathrm{L} \\
\mathrm{L} \\
\mathrm{L}\end{array}$ & $\begin{array}{r}15 \\
10 \\
10 \\
15 \\
7\end{array}$ \\
\hline $\begin{array}{l}303 \\
304 \\
715\end{array}$ & $\begin{array}{l}1.5 \\
3 \\
3\end{array}$ & .3 & $\begin{array}{r}1.5 \\
.5\end{array}$ & $\begin{array}{l}.15 \\
.15 \\
.3\end{array}$ & $\begin{array}{l}300 \\
500 \\
300\end{array}$ & $\begin{array}{l}20 \\
70 \\
15\end{array}$ & $\begin{array}{l}200 \\
700 \\
500\end{array}$ & $\begin{array}{l}1 \\
1\end{array}$ & $\begin{array}{r}L \\
10 \\
30\end{array}$ & $\begin{array}{r}30 \\
30 \\
200\end{array}$ & $\begin{array}{r}7 \\
10 \\
15\end{array}$ & $\begin{array}{r}L \\
20 \\
20\end{array}$ & $\begin{array}{l}\mathrm{N} \\
\mathrm{N} \\
\mathrm{N}\end{array}$ & $\begin{array}{l}\mathrm{N} \\
\mathrm{L}\end{array}$ & $\begin{array}{l}L \\
15 \\
70\end{array}$ \\
\hline
\end{tabular}

Silt samples

\begin{tabular}{|c|c|c|c|c|c|c|c|c|c|c|c|c|c|c|c|}
\hline $\begin{array}{l}205 \\
295 \\
306 \\
308 \\
311\end{array}$ & $\begin{array}{l}2 \\
3 \\
5 \\
5 \\
5\end{array}$ & $\begin{array}{l}1.5 \\
1.5 \\
1.7 \\
1.7\end{array}$ & $\begin{array}{l}1 \\
1.5 \\
1 \\
2 \\
1.5\end{array}$ & $\begin{array}{l}0.2 \\
.5 \\
.15 \\
.2 \\
.2\end{array}$ & $\begin{array}{r}150 \\
1,000 \\
500 \\
500 \\
500\end{array}$ & $\begin{array}{r}\mathbf{N} \\
\mathbf{N} \\
70 \\
50 \\
30\end{array}$ & $\begin{array}{l}150 \\
150 \\
500 \\
700 \\
700\end{array}$ & $\begin{array}{l}\text { L } \\
\text { L } \\
\text { L } \\
\text { L }\end{array}$ & $\begin{array}{l}15 \\
15 \\
15 \\
15 \\
15\end{array}$ & $\begin{array}{l}70 \\
70 \\
70 \\
50 \\
70\end{array}$ & $\begin{array}{r}5 \\
15 \\
15 \\
10 \\
15\end{array}$ & $\begin{array}{l}50 \\
70 \\
20 \\
30 \\
50\end{array}$ & $\begin{array}{l}\mathbf{N} \\
\mathbf{N} \\
\mathbf{N} \\
\mathbf{N} \\
\mathbf{N}\end{array}$ & $\begin{array}{l}L \\
L \\
L \\
L \\
L\end{array}$ & $\begin{array}{l}70 \\
30 \\
20 \\
15 \\
20\end{array}$ \\
\hline $\begin{array}{l}312 \\
318 \\
334 \\
344 \\
345\end{array}$ & $\begin{array}{l}5 \\
2 \\
3 \\
3 \\
3\end{array}$ & $\begin{array}{l}1 \\
.7 \\
.7 \\
1.5 \\
1.5\end{array}$ & $\begin{array}{r}1.5 \\
.7 \\
.5 \\
.7 \\
.7\end{array}$ & $\begin{array}{l}.2 \\
.15 \\
.15 \\
.15 \\
.15\end{array}$ & $\begin{array}{l}500 \\
150 \\
200 \\
300 \\
500\end{array}$ & $\begin{array}{l}50 \\
\text { H } \\
L \\
L \\
L\end{array}$ & $\begin{array}{l}700 \\
300 \\
300 \\
500 \\
500\end{array}$ & $\begin{array}{l}1 \\
1 \\
1 \\
1 \\
1\end{array}$ & $\begin{array}{r}15 \\
\mathrm{~L} \\
7 \\
15 \\
20\end{array}$ & $\begin{array}{r}70 \\
5 \\
20 \\
70 \\
70\end{array}$ & $\begin{array}{l}15 \\
15 \\
15 \\
15 \\
15\end{array}$ & $\begin{array}{r}30 \\
30 \\
200 \\
70 \\
100\end{array}$ & $\begin{array}{l}\mathbf{N} \\
\mathbf{N} \\
\mathbf{N} \\
\mathbf{N} \\
\mathbf{N}\end{array}$ & $\begin{array}{l}\text { L } \\
\text { L } \\
\text { L } \\
\text { L } \\
\text { L }\end{array}$ & $\begin{array}{r}15 \\
5 \\
10 \\
30 \\
30\end{array}$ \\
\hline $\begin{array}{l}352 \\
767 \\
776 \\
957 \\
959\end{array}$ & $\begin{array}{l}3 \\
7 \\
3 \\
3 \\
5\end{array}$ & $\begin{array}{l}3^{.7} \\
1.5 \\
1.5 \\
2^{-5}\end{array}$ & $\begin{array}{l}2^{.7} \\
1.5 \\
1.5 \\
1.5\end{array}$ & $\begin{array}{l}.2 \\
.3 \\
.2 \\
.2 \\
.2\end{array}$ & $\begin{array}{l}300 \\
700 \\
300 \\
200 \\
700\end{array}$ & $\begin{array}{r}L \\
H \\
N \\
10 \\
L\end{array}$ & $\begin{array}{l}300 \\
300 \\
300 \\
700 \\
500\end{array}$ & $\begin{array}{l}1 \\
\mathrm{~L} \\
\mathrm{~L} \\
1 \\
\mathrm{~L}\end{array}$ & $\begin{array}{l}15 \\
15 \\
15 \\
15 \\
20\end{array}$ & $\begin{array}{r}70 \\
300 \\
200 \\
300 \\
200\end{array}$ & $\begin{array}{r}20 \\
20 \\
7 \\
15 \\
30\end{array}$ & $\begin{array}{r}50 \\
70 \\
30 \\
150 \\
150\end{array}$ & $\begin{array}{l}N \\
N \\
N \\
N \\
N\end{array}$ & $\begin{array}{l}\mathrm{L} \\
\mathbf{L} \\
\mathbf{L} \\
\mathbf{L} \\
\mathbf{L}\end{array}$ & $\begin{array}{r}20 \\
100 \\
70 \\
70 \\
50\end{array}$ \\
\hline $\begin{array}{r}960 \\
994 \\
1047 \\
1060 \\
1062\end{array}$ & $\begin{array}{r}10 \\
5 \\
3 \\
3 \\
3\end{array}$ & $\begin{array}{l}3 \\
1.5 \\
1.5 \\
1.5 \\
1\end{array}$ & $\begin{array}{l}1 \\
1.5 \\
1.5 \\
2 \\
1\end{array}$ & $\begin{array}{l}.3 \\
.3 \\
.3 \\
.15 \\
.2\end{array}$ & $\begin{array}{r}1,000 \\
1,000 \\
300 \\
500 \\
500\end{array}$ & $\begin{array}{c}10 \\
L \\
N \\
L \\
L\end{array}$ & $\begin{array}{l}500 \\
500 \\
300 \\
700 \\
700\end{array}$ & $\begin{array}{l}L \\
L \\
L \\
L \\
1\end{array}$ & $\begin{array}{l}20 \\
15 \\
15 \\
10 \\
15\end{array}$ & $\begin{array}{r}200 \\
150 \\
1,000 \\
70 \\
70\end{array}$ & $\begin{array}{r}70 \\
10 \\
7 \\
7 \\
10\end{array}$ & $\begin{array}{r}150 \\
70 \\
L \\
150 \\
100\end{array}$ & $\begin{array}{l}\mathbf{N} \\
\mathbf{N} \\
\mathbf{N} \\
\mathbf{N} \\
\mathbf{N}\end{array}$ & $\begin{array}{r}15 \\
\text { L } \\
L \\
L \\
L\end{array}$ & $\begin{array}{r}70 \\
50 \\
100 \\
20 \\
30\end{array}$ \\
\hline 1080 & 3 & 1 & .7 & .3 & 300 & 15 & 300 & $\mathbf{L}$ & 10 & 20 & 10 & 70 & $N$ & $\mathrm{~L}$ & 20 \\
\hline
\end{tabular}

\section{Organic silt samples}

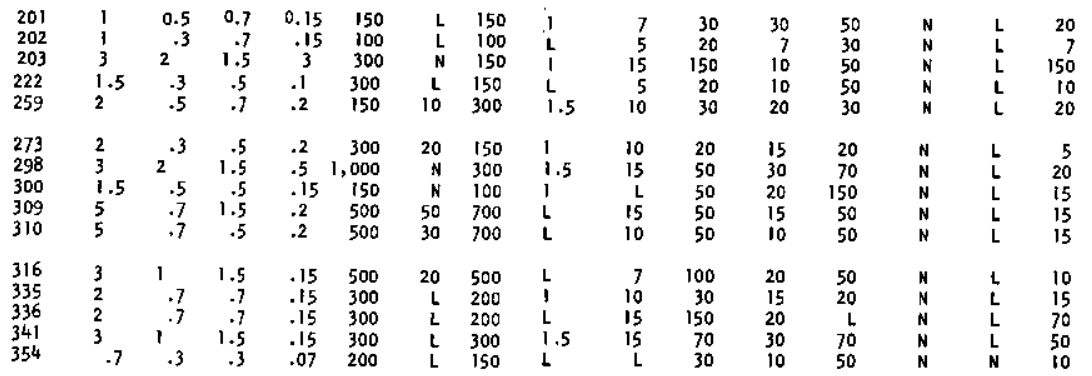


from the Glacier Primitive Area, Fremon County

" $\mathrm{S}$ " are south of the Wind River base meridian]

Semiquantitative spectrographic analyses--Continued

\begin{tabular}{|c|c|c|c|c|c|c|c|c|c|}
\hline \multirow[b]{2}{*}{ Sample } & \multicolumn{6}{|c|}{ (ppm) } & \multirow{2}{*}{$\frac{(\mathrm{pgm})}{\mathrm{C} \times \mathrm{HM}}$} & \multirow[b]{2}{*}{$\begin{array}{l}\text { Locat ion } \\
\text { Sec-Twp-Rge }\end{array}$} & \multirow[b]{2}{*}{ Orainage basin } \\
\hline & $\begin{array}{l}\mathrm{Pb} \\
(10)\end{array}$ & $\begin{array}{l}\text { Sc } \\
\text { (5) }\end{array}$ & $\begin{array}{c}S r \\
(100)\end{array}$ & $\begin{array}{c}V \\
(10)\end{array}$ & $\begin{array}{c}Y \\
(10)\end{array}$ & $\begin{array}{c}2 r \\
(10)\end{array}$ & & & \\
\hline
\end{tabular}

Soil samples

\begin{tabular}{|c|c|c|c|c|c|c|c|c|c|}
\hline $\begin{array}{l}206 \\
207 \\
216 \\
221 \\
223\end{array}$ & $\begin{array}{l}15 \\
20 \\
30 \\
30 \\
50\end{array}$ & $\begin{array}{r}7 \\
7 \\
7 \\
15 \\
7\end{array}$ & $\begin{array}{r}100 \\
100 \\
L \\
100 \\
N\end{array}$ & $\begin{array}{l}30 \\
30 \\
30 \\
70 \\
20\end{array}$ & $\begin{array}{l}15 \\
20 \\
20 \\
30 \\
15\end{array}$ & $\begin{array}{l}150 \\
200 \\
150 \\
200 \\
150\end{array}$ & $\begin{array}{l}1 \\
1 \\
3 \\
3 \\
1\end{array}$ & $\begin{array}{r}12-38-107 \\
18-38-106 \\
32-39-106 \\
3-38-106 \\
34-40-106\end{array}$ & $\begin{array}{c}\text { Dinwoody Cr. } \\
\text { Do. } \\
\text { Do. } \\
\text { Do. } \\
\text { Blue Hole or. }\end{array}$ \\
\hline $\begin{array}{l}225 \\
226 \\
227 \\
236 \\
302\end{array}$ & $\begin{array}{l}50 \\
20 \\
30 \\
15 \\
20\end{array}$ & $\begin{array}{l}7 \\
5 \\
5 \\
5 \\
6\end{array}$ & $\begin{array}{l}N \\
N \\
L \\
L \\
L\end{array}$ & $\begin{array}{l}30 \\
20 \\
20 \\
15 \\
15\end{array}$ & $\begin{array}{l}20 \\
15 \\
20 \\
20 \\
15\end{array}$ & $\begin{array}{l}150 \\
150 \\
150 \\
150 \\
150\end{array}$ & $\begin{array}{l}1 \\
3 \\
1 \\
1 \\
1\end{array}$ & $\begin{array}{l}26-40-106 \\
26-40-106 \\
25-40-106 \\
13-39-107 \\
13-40-107\end{array}$ & $\begin{array}{c}\text { Do. } \\
\text { Oo. } \\
\text { Do. } \\
\text { Torrey Cr. } \\
\text { Do. }\end{array}$ \\
\hline $\begin{array}{l}303 \\
304 \\
715\end{array}$ & $\begin{array}{l}15 \\
15 \\
10\end{array}$ & $\begin{array}{r}L \\
5 \\
10\end{array}$ & $\begin{array}{r}\mathrm{N} \\
100\end{array}$ & $\begin{array}{l}15 \\
20 \\
50\end{array}$ & $\begin{array}{l}10 \\
20 \\
15\end{array}$ & $\begin{array}{l}100 \\
150 \\
200\end{array}$ & $\begin{array}{l}3 \\
1 \\
3\end{array}$ & $\begin{array}{l}13-40-107 \\
18-40-106 \\
34-41-107\end{array}$ & $\begin{array}{c}\text { Do. } \\
\text { Do. } \\
\text { Jakeys Fork. }\end{array}$ \\
\hline \multicolumn{10}{|c|}{ silt samples } \\
\hline $\begin{array}{l}205 \\
295 \\
306 \\
308 \\
311\end{array}$ & $\begin{array}{l}10 \\
20 \\
15 \\
15 \\
20\end{array}$ & $\begin{array}{r}7 \\
15 \\
7 \\
7 \\
10\end{array}$ & $\begin{array}{r}100 \\
100 \\
N \\
N \\
N\end{array}$ & $\begin{array}{l}30 \\
70 \\
30 \\
15 \\
50\end{array}$ & $\begin{array}{l}15 \\
30 \\
15 \\
20 \\
20\end{array}$ & $\begin{array}{l}150 \\
300 \\
100 \\
150 \\
150\end{array}$ & $\begin{array}{l}1 \\
4 \\
1 \\
1 \\
1\end{array}$ & $\begin{array}{r}12-38-107 \\
7-30-107 \\
7-40-106 \\
7-40-106 \\
8-40-106\end{array}$ & $\begin{array}{c}\text { Oinwoody } \mathrm{Cr} \text {. } \\
\text { Jakeys Fork. } \\
\text { Torrey Cr. } \\
\text { Do. } \\
\text { Do. }\end{array}$ \\
\hline $\begin{array}{l}312 \\
318 \\
334 \\
344 \\
345\end{array}$ & $\begin{array}{r}20 \\
10 \\
30 \\
50 \\
100\end{array}$ & $\begin{array}{r}7 \\
L \\
7 \\
10 \\
10\end{array}$ & $\begin{array}{r}100 \\
L \\
L \\
100 \\
100\end{array}$ & $\begin{array}{l}30 \\
10 \\
30 \\
50 \\
50\end{array}$ & $\begin{array}{r}20 \\
10 \\
150 \\
30 \\
30\end{array}$ & $\begin{array}{l}150 \\
150 \\
300 \\
150 \\
100\end{array}$ & $\begin{array}{l}1 \\
1 \\
1 \\
1 \\
1\end{array}$ & $\begin{array}{r}8-40-106 \\
6-38-106 \\
28-39-106 \\
25-39-106 \\
24-39-107\end{array}$ & $\begin{array}{c}\text { Do. } \\
\text { Dimwoody Cr. } \\
\text { Do. } \\
\text { Torrey Cr. } \\
\text { Do. }\end{array}$ \\
\hline $\begin{array}{l}352 \\
767 \\
776 \\
957 \\
959\end{array}$ & $\begin{array}{l}30 \\
30 \\
20 \\
20 \\
70\end{array}$ & $\begin{array}{r}10 \\
10 \\
7 \\
15 \\
15\end{array}$ & $\begin{array}{r}L \\
100 \\
L \\
200 \\
200\end{array}$ & $\begin{array}{r}50 \\
100 \\
50 \\
50 \\
50\end{array}$ & $\begin{array}{l}30 \\
20 \\
20 \\
30 \\
30\end{array}$ & $\begin{array}{r}300 \\
70 \\
150 \\
150 \\
100\end{array}$ & $\begin{array}{l}3 \\
5 \\
1 \\
3 \\
5\end{array}$ & $\begin{array}{r}12-39-107 \\
5-36-106 \\
30-37-105 \\
23-37-106 \\
18-36-106\end{array}$ & $\begin{array}{l}\text { Do. } \\
\text { Bull Lake Cr. } \\
\text { Do. } \\
\text { Do. } \\
\text { Do. }\end{array}$ \\
\hline $\begin{array}{r}960 \\
994 \\
1047 \\
1060 \\
1062\end{array}$ & $\begin{array}{r}100 \\
50 \\
20 \\
30 \\
70\end{array}$ & $\begin{array}{l}15 \\
15 \\
15 \\
15 \\
15\end{array}$ & $\begin{array}{l}150 \\
200 \\
100 \\
700 \\
300\end{array}$ & $\begin{array}{r}100 \\
70 \\
70 \\
50 \\
70\end{array}$ & $\begin{array}{l}30 \\
30 \\
15 \\
30 \\
30\end{array}$ & $\begin{array}{r}150 \\
100 \\
50 \\
100 \\
150\end{array}$ & $\begin{array}{r}8 \\
17 \\
3 \\
7 \\
11\end{array}$ & $\begin{array}{r}18-36-106 \\
5-35-106 \\
31-38-105 \\
7-35-106 \\
8-35-106\end{array}$ & $\begin{array}{c}\text { Do. } \\
\text { Do. } \\
\text { Ory Cr. } \\
\text { Bull Lake Cr. } \\
\text { Do. }\end{array}$ \\
\hline 1080 & 30 & 7 & 150 & 70 & 20 & 150 & 5 & $15-35-106$ & Do. \\
\hline \multicolumn{10}{|c|}{ Organic silt } \\
\hline $\begin{array}{l}201 \\
202 \\
203 \\
222 \\
259\end{array}$ & $\begin{array}{l}15 \\
15 \\
10 \\
20 \\
30\end{array}$ & $\begin{array}{r}7 \\
5 \\
10 \\
5 \\
7\end{array}$ & $\begin{array}{r}\text { N } \\
100 \\
N \\
\mathrm{~L}\end{array}$ & $\begin{array}{l}30 \\
20 \\
50 \\
20 \\
30\end{array}$ & $\begin{array}{l}30 \\
15 \\
20 \\
30 \\
15\end{array}$ & $\begin{array}{l}150 \\
150 \\
150 \\
100 \\
100\end{array}$ & $\begin{array}{l}1 \\
1 \\
1 \\
3 \\
1\end{array}$ & $\begin{array}{l}11-38-106 \\
11-38-106 \\
11-38-106 \\
4-38-106 \\
4-38-106\end{array}$ & $\begin{array}{c}\text { Dimmoody } \mathrm{Cr} . \\
\text { Do. } \\
\text { Do. } \\
\text { Do. } \\
\text { Do. }\end{array}$ \\
\hline $\begin{array}{l}273 \\
298 \\
300 \\
309 \\
310\end{array}$ & $\begin{array}{l}50 \\
30 \\
50 \\
15 \\
15\end{array}$ & $\begin{array}{r}5 \\
15 \\
5 \\
7 \\
7\end{array}$ & $\begin{array}{r}L \\
200 \\
N \\
L \\
N\end{array}$ & $\begin{array}{l}70 \\
70 \\
50 \\
20 \\
30\end{array}$ & $\begin{array}{l}15 \\
20 \\
30 \\
20 \\
20\end{array}$ & $\begin{array}{r}100 \\
300 \\
50 \\
150 \\
150\end{array}$ & $\begin{array}{l}1 \\
2 \\
5 \\
1 \\
1\end{array}$ & $\begin{array}{r}21-38-106 \\
6-39-106 \\
1-39-108 \\
7-40-106 \\
7-40-106\end{array}$ & $\begin{array}{c}\text { Do. } \\
\text { Jakeys Fork. } \\
\text { Do. } \\
\text { Torrey Cr. } \\
\text { Do. }\end{array}$ \\
\hline $\begin{array}{l}316 \\
335 \\
336 \\
341 \\
354\end{array}$ & $\begin{array}{l}20 \\
30 \\
20 \\
50 \\
30\end{array}$ & $\begin{array}{r}5 \\
7 \\
7 \\
10 \\
\mathrm{~L}\end{array}$ & $\begin{array}{r}100 \\
\mathbf{L} \\
\mathbf{N} \\
100 \\
\mathrm{~N}\end{array}$ & $\begin{array}{l}20 \\
30 \\
30 \\
30 \\
15\end{array}$ & $\begin{array}{l}15 \\
30 \\
15 \\
30 \\
20\end{array}$ & $\begin{array}{l}150 \\
150 \\
150 \\
150 \\
100\end{array}$ & $\begin{array}{l}1 \\
1 \\
1 \\
3 \\
1\end{array}$ & $\begin{array}{l}33-41-106 \\
28-30-106 \\
31-39-105 \\
32-39-106 \\
25-40-107\end{array}$ & $\begin{array}{c}\text { Do. } \\
\text { Dirmoody } \mathrm{Cr} . \\
\text { Do. } \\
\text { Do. } \\
\text { Torrey Cr. }\end{array}$ \\
\hline
\end{tabular}


Semiquantitative spectrographic analyses

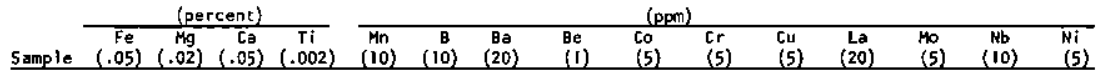

Organic silt samples--Continued

\begin{tabular}{|c|c|c|c|c|c|c|c|c|c|c|c|c|c|c|c|}
\hline $\begin{array}{l}355 \\
3751 \\
382 \\
398 \\
602\end{array}$ & $\begin{array}{l}0.2 \\
2 \\
1 \\
5 \\
3\end{array}$ & $\begin{array}{r}.07 \\
.5 \\
.3 \\
1.5 \\
1\end{array}$ & $\begin{array}{r}0.2 \\
.7 \\
.5 \\
.7 \\
1.5\end{array}$ & $\begin{array}{c}0.03 \\
.3 \\
.15 \\
.3 \\
.5\end{array}$ & $\begin{array}{l}100 \\
300 \\
300 \\
300 \\
500\end{array}$ & $\begin{array}{r}L \\
H \\
15 \\
15 \\
10\end{array}$ & $\begin{array}{r}50 \\
150 \\
150 \\
300 \\
300\end{array}$ & $\begin{array}{l}\mathrm{L} \\
\mathrm{L} \\
1.5 \\
1.5\end{array}$ & $\begin{array}{r}L \\
15 \\
7 \\
15 \\
15\end{array}$ & $\begin{array}{r}10 \\
20 \\
20 \\
100 \\
150\end{array}$ & $\begin{array}{r}7 \\
15 \\
10 \\
30 \\
30\end{array}$ & $\begin{array}{l}30 \\
70 \\
70 \\
70 \\
30\end{array}$ & $\begin{array}{l}\mathbf{N} \\
\mathbf{N} \\
\mathbf{N} \\
\mathrm{N} \\
\mathrm{L}\end{array}$ & $\begin{array}{c}\mathrm{N} \\
\mathrm{L} \\
\mathrm{N} \\
15 \\
\mathrm{~L}\end{array}$ & $\begin{array}{r}\mathrm{L} \\
7 \\
7 \\
50 \\
70\end{array}$ \\
\hline $\begin{array}{l}607 \\
611 \\
615 \\
618 \\
631\end{array}$ & $\begin{array}{l}1.5 \\
3 \\
3 \\
1 \\
3\end{array}$ & $\begin{array}{l}.5 \\
.7 \\
.15 \\
.7\end{array}$ & $\begin{array}{l}1 \\
1.5 \\
1.5 \\
.7 \\
.7\end{array}$ & $\begin{array}{l}.2 \\
.5 \\
.5 \\
.15 \\
.3\end{array}$ & $\begin{array}{l}150 \\
500 \\
500 \\
150 \\
300\end{array}$ & $\begin{array}{l}N \\
N \\
10 \\
10 \\
15\end{array}$ & $\begin{array}{l}200 \\
300 \\
300 \\
300 \\
200\end{array}$ & $\begin{array}{l}1 \\
1.5 \\
1.5 \\
1.5 \\
1\end{array}$ & $\begin{array}{r}7 \\
15 \\
15 \\
L \\
15\end{array}$ & $\begin{array}{r}70 \\
100 \\
150 \\
15 \\
70\end{array}$ & $\begin{array}{l}10 \\
10 \\
15 \\
10 \\
20\end{array}$ & $\begin{array}{r}30 \\
70 \\
150 \\
20 \\
70\end{array}$ & $\begin{array}{l}N \\
N \\
7 \\
N \\
N\end{array}$ & $\begin{array}{l}L \\
L \\
L \\
N \\
L\end{array}$ & $\begin{array}{r}20 \\
50 \\
20 \\
7 \\
30\end{array}$ \\
\hline $\begin{array}{l}652 \\
655 \\
657 \\
659 \\
660\end{array}$ & $\begin{array}{l}3 \\
1.5 \\
2 \\
2 \\
\quad .7\end{array}$ & $\begin{array}{l}.5 \\
.5 \\
.7 \\
.7 \\
.2\end{array}$ & $\begin{array}{l}.3 \\
.7 \\
.7 \\
.7 \\
.3\end{array}$ & $\begin{array}{l}.3 \\
.15 \\
.3 \\
.3 \\
.07\end{array}$ & $\begin{array}{r}150 \\
200 \\
300 \\
300 \\
70\end{array}$ & $\begin{array}{r}50 \\
10 \\
10 \\
15 \\
\mathrm{~L}\end{array}$ & $\begin{array}{l}500 \\
150 \\
300 \\
200 \\
100\end{array}$ & $\begin{array}{l}1.5 \\
1.5 \\
1.5 \\
2\end{array}$ & $\begin{array}{l}10 \\
10 \\
15 \\
15 \\
N\end{array}$ & $\begin{array}{r}50 \\
70 \\
70 \\
150 \\
20\end{array}$ & $\begin{array}{l}10 \\
15 \\
15 \\
15 \\
15\end{array}$ & $\begin{array}{r}50 \\
70 \\
50 \\
70 \\
150\end{array}$ & $\begin{array}{l}\mathbf{N} \\
\mathbf{N} \\
\mathbf{N} \\
\mathbf{N} \\
\mathbf{N}\end{array}$ & $\begin{array}{r}L \\
L \\
L \\
10 \\
L\end{array}$ & $\begin{array}{l}15 \\
20 \\
20 \\
70 \\
10\end{array}$ \\
\hline $\begin{array}{l}663 \\
667 \\
669 \\
697 \\
705\end{array}$ & $\begin{array}{l}1 \\
3 \\
3 \\
5 \\
3\end{array}$ & $\begin{array}{r}.2 \\
1.5 \\
.7 \\
.3\end{array}$ & $\begin{array}{l}.5 \\
1.5 \\
1.5 \\
.5\end{array}$ & $\begin{array}{l}.2 \\
.3 \\
.3 \\
.5 \\
.3\end{array}$ & $\begin{array}{l}300 \\
500 \\
700 \\
700 \\
200\end{array}$ & $\begin{array}{c}L \\
L \\
L \\
15\end{array}$ & $\begin{array}{l}100 \\
300 \\
500 \\
200 \\
300\end{array}$ & $\begin{array}{l}1 \\
1 \\
2 \\
1 \\
1\end{array}$ & $\begin{array}{r}5 \\
20 \\
15 \\
20 \\
10\end{array}$ & $\begin{array}{r}15 \\
200 \\
70 \\
300 \\
200\end{array}$ & $\begin{array}{r}10 \\
15 \\
15 \\
100 \\
10\end{array}$ & $\begin{array}{l}70 \\
50 \\
50 \\
30 \\
70\end{array}$ & $\begin{array}{l}\mathrm{L} \\
\mathrm{N} \\
\mathrm{N} \\
\mathrm{N} \\
\mathrm{N}\end{array}$ & $\begin{array}{r}L \\
L \\
10 \\
L \\
L\end{array}$ & $\begin{array}{r}7 \\
70 \\
20 \\
100 \\
50\end{array}$ \\
\hline $\begin{array}{l}709 \\
721 \\
728 \\
739 \\
740\end{array}$ & $\begin{array}{l}3 \\
1.5 \\
1.5 \\
5 \\
2\end{array}$ & $2_{.7}^{.7} .35$ & $\begin{array}{l}1 \\
.7 \\
.3 \\
.7 \\
.7\end{array}$ & $\begin{array}{l}.3 \\
.2 \\
.2 \\
.3 \\
.2\end{array}$ & $\begin{array}{r}500 \\
300 \\
700 \\
1,000 \\
500\end{array}$ & $\begin{array}{r}L \\
L \\
10 \\
10 \\
L\end{array}$ & $\begin{array}{l}500 \\
300 \\
500 \\
300 \\
150\end{array}$ & $\begin{array}{l}\mathrm{I} \\
\mathrm{L} \\
1.5\end{array}$ & $\begin{array}{r}10 \\
10 \\
5 \\
15 \\
10\end{array}$ & $\begin{array}{r}150 \\
30 \\
20 \\
150 \\
200\end{array}$ & $\begin{array}{r}15 \\
5 \\
L \\
20 \\
10\end{array}$ & $\begin{array}{r}100 \\
50 \\
20 \\
50 \\
50\end{array}$ & $\begin{array}{l}\mathbf{N} \\
\mathbf{N} \\
\mathbf{N} \\
\mathbf{N} \\
\mathbf{N}\end{array}$ & $\begin{array}{l}\mathrm{L} \\
N \\
N \\
L \\
L\end{array}$ & $\begin{array}{r}30 \\
30 \\
5 \\
70 \\
50\end{array}$ \\
\hline $\begin{array}{l}744 \\
745 \\
746 \\
747 \\
759\end{array}$ & $\begin{array}{l}2 \\
1.5 \\
2_{3}^{.7}\end{array}$ & $\begin{array}{l}.7 \\
.3 \\
.15 \\
1.5 \\
1.5\end{array}$ & $\begin{array}{l}.7 \\
.3 \\
.3 \\
.5 \\
.1\end{array}$ & $\begin{array}{l}.2 \\
.1 \\
.05 \\
.15 \\
.2\end{array}$ & $\begin{array}{l}300 \\
300 \\
200 \\
150 \\
700\end{array}$ & $\begin{array}{l}\mathbf{L} \\
\mathbf{L} \\
\mathbf{N} \\
\mathbf{N} \\
\mathbf{N}\end{array}$ & $\begin{array}{l}200 \\
150 \\
100 \\
200 \\
200\end{array}$ & $\begin{array}{l}1 \\
1 \\
1 \\
1 \\
1\end{array}$ & $\begin{array}{r}7 \\
7 \\
\mathrm{~L} \\
10 \\
30\end{array}$ & $\begin{array}{r}150 \\
100 \\
50 \\
300 \\
300\end{array}$ & $\begin{array}{r}15 \\
15 \\
5 \\
5 \\
10\end{array}$ & $\begin{array}{l}70 \\
70 \\
20 \\
30 \\
20\end{array}$ & $\begin{array}{l}\mathbf{N} \\
\mathbf{N} \\
\mathbf{N} \\
\mathrm{N} \\
\mathrm{N}\end{array}$ & $\begin{array}{l}\text { N } \\
N \\
N \\
L \\
L\end{array}$ & $\begin{array}{r}50 \\
30 \\
10 \\
70 \\
150\end{array}$ \\
\hline $\begin{array}{l}768 \\
772 \\
781 \\
794 \\
795\end{array}$ & $\begin{array}{l}7 \\
1.5 \\
3 \\
3 \\
1\end{array}$ & $\begin{array}{r}3 \\
.7 \\
.7 \\
1.5 \\
.3\end{array}$ & $\begin{array}{r}1.5 \\
.5 \\
.7 \\
.7 \\
.5\end{array}$ & $\begin{array}{l}.3 \\
.15 \\
.2 \\
.2 \\
.15\end{array}$ & $\begin{array}{l}700 \\
300 \\
150 \\
300 \\
100\end{array}$ & $\begin{array}{l}N \\
\mathrm{~L} \\
N \\
\mathrm{~L}\end{array}$ & $\begin{array}{l}500 \\
200 \\
500 \\
500 \\
200\end{array}$ & $\begin{array}{l}\mathrm{L} \\
\mathrm{l} \\
\mathrm{L} \\
\mathrm{L} \\
\mathrm{L}\end{array}$ & $\begin{array}{r}15 \\
10 \\
5 \\
15 \\
N\end{array}$ & $\begin{array}{r}300 \\
50 \\
30 \\
200 \\
50\end{array}$ & $\begin{array}{r}20 \\
20 \\
7 \\
15 \\
10\end{array}$ & $\begin{array}{r}70 \\
100 \\
50 \\
30 \\
50\end{array}$ & $\begin{array}{l}\mathrm{N} \\
\mathrm{N} \\
\mathrm{N} \\
\mathrm{N} \\
\mathrm{N}\end{array}$ & $\begin{array}{c}10 \\
L \\
L \\
L \\
N\end{array}$ & $\begin{array}{l}70 \\
30 \\
20 \\
50 \\
30\end{array}$ \\
\hline $\begin{array}{l}796 \\
797 \\
800 \\
901 \\
903\end{array}$ & $\begin{array}{l}3.7 \\
1.5 \\
3 \\
2\end{array}$ & $\begin{array}{l}.75 \\
.5 \\
1\end{array}$ & $\begin{array}{l}1.3 \\
1^{.7}\end{array}$ & $\begin{array}{l}.2 \\
.07 \\
.2 \\
.5 \\
.3\end{array}$ & $\begin{array}{l}500 \\
150 \\
150 \\
300 \\
700\end{array}$ & $\begin{array}{r}\mathrm{N} \\
\mathrm{N} \\
\mathrm{N} \\
\mathrm{IS} \\
\mathrm{L}\end{array}$ & $\begin{array}{l}200 \\
100 \\
150 \\
700 \\
200\end{array}$ & $\begin{array}{l}\mathbf{L} \\
\mathbf{L} \\
\mathbf{L} \\
1 \\
1\end{array}$ & $\begin{array}{r}15 \\
N \\
5 \\
15 \\
15\end{array}$ & $\begin{array}{r}200 \\
30 \\
50 \\
200 \\
200\end{array}$ & $\begin{array}{r}15 \\
7 \\
5 \\
15 \\
10\end{array}$ & $\begin{array}{l}50 \\
50 \\
50 \\
70 \\
30\end{array}$ & $\begin{array}{l}\mathrm{N} \\
\mathbf{N} \\
\mathrm{N} \\
\mathrm{N} \\
\mathrm{N}\end{array}$ & $\begin{array}{r}\mathrm{L} \\
\mathrm{N} \\
\mathrm{N} \\
10 \\
\mathrm{~L}\end{array}$ & $\begin{array}{r}70 \\
15 \\
30 \\
70 \\
100\end{array}$ \\
\hline $\begin{array}{l}906 \\
908 \\
912 \\
913 \\
914\end{array}$ & $\begin{array}{l}3 \\
3 \\
3 \\
1.5 \\
5\end{array}$ & $\begin{array}{l}1 \\
1 \\
1.5 \\
.3 \\
1.5\end{array}$ & $1^{.7} 2^{.3}$ & $\begin{array}{l}.3 \\
.3 \\
.2 \\
.07 \\
.5\end{array}$ & $\begin{array}{r}1,000 \\
300 \\
700 \\
200 \\
700\end{array}$ & $\begin{array}{r}10 \\
N \\
10 \\
10 \\
N\end{array}$ & $\begin{array}{l}200 \\
300 \\
200 \\
150 \\
300\end{array}$ & $\begin{array}{l}1.5 \\
1 \\
1 \\
1 \\
1\end{array}$ & $\begin{array}{l}50 \\
20 \\
30 \\
10 \\
30\end{array}$ & $\begin{array}{l}300 \\
200 \\
500 \\
150 \\
300\end{array}$ & $\begin{array}{l}15 \\
30 \\
20 \\
15 \\
15\end{array}$ & $\begin{array}{l}50 \\
20 \\
70 \\
30 \\
20\end{array}$ & $\begin{array}{l}\mathrm{N} \\
\mathrm{N} \\
\mathrm{N} \\
\mathrm{N} \\
\mathrm{N}\end{array}$ & $\begin{array}{c}L \\
L \\
10 \\
L \\
L\end{array}$ & $\begin{array}{r}150 \\
100 \\
200 \\
50 \\
150\end{array}$ \\
\hline $\begin{array}{l}919 \\
921 \\
934 \\
965 \\
968\end{array}$ & $\begin{array}{l}5 \\
3 \\
5 \\
3 \\
7\end{array}$ & $\begin{array}{l}1.5 \\
1 \\
1.5 \\
1.5 \\
3\end{array}$ & $\begin{array}{l}2 \\
1 \\
1.5 \\
1.5 \\
2\end{array}$ & $\begin{array}{l}.3 \\
.3 \\
.3 \\
.2 \\
.2\end{array}$ & $\begin{array}{l}700 \\
700 \\
700 \\
500 \\
700\end{array}$ & $\begin{array}{r}\mathrm{N} \\
\mathrm{N} \\
\mathrm{L} \\
10 \\
\mathrm{~N}\end{array}$ & $\begin{array}{l}150 \\
200 \\
300 \\
300 \\
300\end{array}$ & $\begin{array}{l}\mathrm{L} \\
\mathrm{I} \\
\mathrm{L} \\
\mathrm{1} \\
\mathrm{I} .5\end{array}$ & $\begin{array}{r}20 \\
20 \\
15 \\
7 \\
15\end{array}$ & $\begin{array}{r}500 \\
150 \\
100 \\
70 \\
500\end{array}$ & $\begin{array}{l}5 \\
15 \\
15 \\
10 \\
15\end{array}$ & $\begin{array}{r}20 \\
20 \\
50 \\
20 \\
150\end{array}$ & $\begin{array}{l}\mathbf{N} \\
\mathbf{N} \\
\mathbf{N} \\
\mathbf{N} \\
\mathbf{N}\end{array}$ & $\begin{array}{l}\mathbf{L} \\
\mathbf{L} \\
\mathbf{L} \\
\mathrm{L} \\
\mathrm{L}\end{array}$ & $\begin{array}{r}100 \\
100 \\
30 \\
30 \\
100\end{array}$ \\
\hline $\begin{array}{r}985 \\
988 \\
996 \\
998 \\
1003\end{array}$ & $\begin{array}{l}3 \\
3 \\
5 \\
7\end{array}$ & $\begin{array}{l}.7 \\
.1 \\
.7 \\
1.5 \\
2\end{array}$ & $\begin{array}{l}1.5 \\
.2 \\
1 \\
1.5 \\
1.5\end{array}$ & $\begin{array}{l}.3 \\
.1 \\
.2 \\
.3 \\
.3\end{array}$ & $\begin{array}{r}300 \\
30 \\
300 \\
500 \\
1,000\end{array}$ & $\begin{array}{c}\mathrm{L} \\
\mathrm{N} \\
\mathrm{L} \\
10 \\
10\end{array}$ & $\begin{array}{r}300 \\
30 \\
200 \\
500 \\
500\end{array}$ & $\begin{array}{l}\mathrm{L} \\
\mathrm{L} \\
\mathrm{L} \\
\mathrm{L} \\
\mathrm{L}\end{array}$ & $\begin{array}{r}10 \\
N \\
10 \\
15 \\
30\end{array}$ & $\begin{array}{r}70 \\
5 \\
15 \\
150 \\
300\end{array}$ & $\begin{array}{r}15 \\
L \\
7 \\
15 \\
150\end{array}$ & $\begin{array}{l}70 \\
50 \\
50 \\
70 \\
50\end{array}$ & $\begin{array}{l}N \\
N \\
N \\
N \\
N\end{array}$ & $\begin{array}{l}L \\
L \\
L \\
L \\
L\end{array}$ & $\begin{array}{r}30 \\
1 \\
20 \\
70 \\
100\end{array}$ \\
\hline $\begin{array}{l}1021 \\
1022 \\
1023 \\
1025 \\
1036\end{array}$ & $\begin{array}{l}2 \\
3 \\
1.5 \\
3 \\
3\end{array}$ & $\begin{array}{r}.7 \\
.7 \\
.3 \\
.7 \\
1.5\end{array}$ & $1_{1}^{.3}$ & $\begin{array}{l}.15 \\
.2 \\
.1 \\
.2 \\
.2\end{array}$ & $\begin{array}{r}200 \\
300 \\
150 \\
1,500 \\
700\end{array}$ & $\begin{array}{c}\text { N } \\
N \\
N \\
L \\
10\end{array}$ & $\begin{array}{l}200 \\
300 \\
300 \\
300 \\
500\end{array}$ & $\begin{array}{l}\mathrm{L} \\
\mathrm{L} \\
\mathrm{L} \\
\mathbf{I} \\
\mathbf{I}\end{array}$ & $\begin{array}{r}5 \\
15 \\
L \\
10 \\
15\end{array}$ & $\begin{array}{r}20 \\
70 \\
30 \\
15 \\
100\end{array}$ & $\begin{array}{r}10 \\
7 \\
5 \\
15 \\
30\end{array}$ & $\begin{array}{r}70 \\
50 \\
20 \\
50 \\
100\end{array}$ & $\begin{array}{l}\mathrm{N} \\
\mathrm{N} \\
\mathrm{N} \\
\mathrm{N} \\
\mathrm{N}\end{array}$ & $\begin{array}{l}\text { N } \\
\text { L } \\
\text { N } \\
N \\
\text { L }\end{array}$ & $\begin{array}{l}30 \\
30 \\
15 \\
20 \\
30\end{array}$ \\
\hline
\end{tabular}

1] Contains $200 \mathrm{ppm} 2 \mathrm{n}$. 
Semiquantitative spectrographic analyses--Continued

\begin{tabular}{|c|c|c|c|c|c|c|c|c|c|}
\hline \multirow[b]{2}{*}{ Sample } & \multicolumn{6}{|c|}{ (ppm) } & \multirow{2}{*}{$\frac{(p p m)}{C x h m}$} & \multirow[b]{2}{*}{$\begin{array}{c}\text { Location } \\
\text { Sec-Twp-Rge }\end{array}$} & \\
\hline & $\begin{array}{r}\mathrm{Pb} \\
(10)\end{array}$ & $\begin{array}{l}\text { Sc } \\
\text { (5) }\end{array}$ & $\begin{array}{c}S r \\
(100)\end{array}$ & $\begin{array}{c}V \\
(10)\end{array}$ & $\begin{array}{c}Y \\
(10)\end{array}$ & $\begin{array}{c}2 r \\
(10)\end{array}$ & & & Drainage basin \\
\hline
\end{tabular}

Organic silt samples--cont inued

\begin{tabular}{|c|c|c|c|c|c|c|c|c|c|}
\hline $\begin{array}{l}355 \\
375 \\
382 \\
398 \\
602\end{array}$ & $\begin{array}{l}15 \\
15 \\
30 \\
50 \\
30\end{array}$ & $\begin{array}{r}L \\
7 \\
14 \\
15 \\
15\end{array}$ & $\begin{array}{r}N \\
L \\
100 \\
100\end{array}$ & $\begin{array}{r}10 \\
70 \\
30 \\
70 \\
100\end{array}$ & $\begin{array}{l}15 \\
30 \\
15 \\
70 \\
20\end{array}$ & $\begin{array}{r}30 \\
70 \\
200 \\
200 \\
200\end{array}$ & $\begin{array}{r}1 \\
100 \\
! \\
5 \\
3\end{array}$ & $\begin{array}{r}30-40-106 \\
11-38-106 \\
13-39-107 \\
2-39-107 \\
35-40-107\end{array}$ & $\begin{array}{c}\text { Torrey Cr. } \\
\text { Dinwoody Cr. } \\
\text { Torrey Cr. } \\
\text { Do. } \\
\text { Do. }\end{array}$ \\
\hline $\begin{array}{l}607 \\
611 \\
615 \\
618 \\
631\end{array}$ & $\begin{array}{l}10 \\
15 \\
10 \\
10 \\
15\end{array}$ & $\begin{array}{r}7 \\
15 \\
15 \\
1 \\
10\end{array}$ & $\begin{array}{r}100 \\
100 \\
150 \\
100 \\
L\end{array}$ & $\begin{array}{l}50 \\
70 \\
70 \\
30 \\
70\end{array}$ & $\begin{array}{l}15 \\
50 \\
20 \\
15 \\
30\end{array}$ & $\begin{array}{l}150 \\
500 \\
150 \\
150 \\
150\end{array}$ & $\begin{array}{r}5 \\
3 \\
3 \\
10 \\
5\end{array}$ & $\begin{array}{l}31-41-107 \\
36-41-108 \\
27-41-108 \\
27-41-108 \\
24-40-108\end{array}$ & $\begin{array}{l}\text { Jakeys Fork. } \\
\text { Do. } \\
\text { Warm Spg Cr. } \\
\text { Do. } \\
\text { Jakeys Fork. }\end{array}$ \\
\hline $\begin{array}{l}652 \\
655 \\
657 \\
659 \\
660\end{array}$ & $\begin{array}{l}30 \\
15 \\
30 \\
20 \\
15\end{array}$ & $\begin{array}{r}10 \\
7 \\
15 \\
10 \\
5\end{array}$ & $\begin{array}{r}100 \\
100 \\
100 \\
100 \\
L\end{array}$ & $\begin{array}{l}30 \\
30 \\
70 \\
70 \\
30\end{array}$ & $\begin{array}{r}20 \\
30 \\
30 \\
30 \\
100\end{array}$ & $\begin{array}{r}300 \\
300 \\
200 \\
150 \\
70\end{array}$ & $\begin{array}{l}8 \\
8 \\
3 \\
1 \\
3\end{array}$ & $\begin{array}{l}36-40-108 \\
30-40-107 \\
23-40-107 \\
14-40-107 \\
14-40-107\end{array}$ & $\begin{array}{l}\text { Do. } \\
\text { Do. } \\
\text { Do. } \\
\text { Do. } \\
\text { Do. }\end{array}$ \\
\hline $\begin{array}{l}663 \\
667 \\
669 \\
697 \\
705\end{array}$ & $\begin{array}{l}20 \\
30 \\
20 \\
20 \\
15\end{array}$ & $\begin{array}{r}5 \\
15 \\
15 \\
10 \\
10\end{array}$ & $\begin{array}{r}L \\
150 \\
300 \\
150 \\
N\end{array}$ & $\begin{array}{r}30 \\
70 \\
70 \\
100 \\
70\end{array}$ & $\begin{array}{l}30 \\
20 \\
30 \\
20 \\
50\end{array}$ & $\begin{array}{r}200 \\
150 \\
300 \\
70 \\
200\end{array}$ & $\begin{array}{l}3 \\
8 \\
1 \\
3 \\
3\end{array}$ & $\begin{array}{l}25-40-108 \\
31-40-107 \\
31-41-108 \\
13-38-106 \\
33-41-107\end{array}$ & $\begin{array}{l}\text { Do. } \\
\text { Do. } \\
\text { Warm Spg Cr. } \\
\text { Dry Cr. } \\
\text { Jakeys Fork. }\end{array}$ \\
\hline $\begin{array}{l}709 \\
721 \\
728 \\
739 \\
740\end{array}$ & $\begin{array}{r}15 \\
\mathrm{~L} \\
\mathrm{~L} \\
100 \\
70\end{array}$ & $\begin{array}{r}7 \\
5 \\
5 \\
15 \\
7\end{array}$ & $\begin{array}{r}100 \\
300 \\
L \\
100 \\
L\end{array}$ & $\begin{array}{l}50 \\
50 \\
30 \\
70 \\
50\end{array}$ & $\begin{array}{l}30 \\
15 \\
15 \\
20 \\
15\end{array}$ & $\begin{array}{r}300 \\
150 \\
100 \\
70 \\
150\end{array}$ & $\begin{array}{l}5 \\
3 \\
3 \\
8 \\
1\end{array}$ & $\begin{array}{r}33-41-107 \\
19-41-107 \\
20-41-108 \\
3-37-106 \\
3-37-106\end{array}$ & $\begin{array}{l}\text { Do. } \\
\text { Warm Spg. Cr. } \\
\text { Do. } \\
\text { Dry Cr. } \\
\text { Do. }\end{array}$ \\
\hline $\begin{array}{l}744 \\
745 \\
746 \\
747 \\
759\end{array}$ & $\begin{array}{l}70 \\
70 \\
10 \\
10 \\
30\end{array}$ & $\begin{array}{r}7 \\
7 \\
5 \\
7 \\
15\end{array}$ & $\begin{array}{l}\mathrm{N} \\
\mathbf{N} \\
\mathbf{N} \\
\mathrm{L} \\
\mathrm{L}\end{array}$ & $\begin{array}{l}70 \\
50 \\
30 \\
50 \\
100\end{array}$ & $\begin{array}{l}20 \\
20 \\
10 \\
15 \\
20\end{array}$ & $\begin{array}{r}70 \\
30 \\
20 \\
150 \\
70\end{array}$ & $\begin{array}{l}3 \\
1 \\
3 \\
3 \\
3\end{array}$ & $\begin{array}{r}3-37-106 \\
2-37-106 \\
2-37-106 \\
1-37-106 \\
26-38-106\end{array}$ & $\begin{array}{l}\text { Do. } \\
\text { Do. } \\
\text { Do. } \\
\text { Do. } \\
\text { Do. }\end{array}$ \\
\hline $\begin{array}{l}768 \\
772 \\
781 \\
794 \\
795\end{array}$ & $\begin{array}{l}30 \\
70 \\
20 \\
20 \\
15\end{array}$ & $\begin{array}{r}15 \\
7 \\
7 \\
10 \\
5\end{array}$ & $\begin{array}{r}150 \\
L \\
L \\
L \\
N\end{array}$ & $\begin{array}{r}100 \\
30 \\
30 \\
70 \\
30\end{array}$ & $\begin{array}{l}15 \\
30 \\
15 \\
10 \\
10\end{array}$ & $\begin{array}{r}70 \\
100 \\
100 \\
100 \\
70\end{array}$ & $\begin{array}{l}5 \\
1 \\
1 \\
1 \\
1\end{array}$ & $\begin{array}{c}4-36-106 \\
31-37-105 \\
24-39-107 \\
3-2-106 \\
3-2-6\end{array}$ & $\begin{array}{c}\text { Bull Lake Cr. } \\
\text { Do. } \\
\text { Torrey Cr. } \\
\text { Bob Cr. } \\
\text { Do. }\end{array}$ \\
\hline $\begin{array}{l}796 \\
797 \\
800 \\
901 \\
903\end{array}$ & $\begin{array}{l}20 \\
15 \\
10 \\
30 \\
15\end{array}$ & $\begin{array}{r}15 \\
5 \\
7 \\
15 \\
7\end{array}$ & $\begin{array}{r}\mathrm{L} \\
\mathrm{N} \\
\mathrm{L} \\
300 \\
\mathrm{~L}\end{array}$ & $\begin{array}{l}50 \\
20 \\
30 \\
70 \\
70\end{array}$ & $\begin{array}{l}15 \\
10 \\
15 \\
20 \\
15\end{array}$ & $\begin{array}{l}500 \\
500 \\
150 \\
300 \\
200\end{array}$ & $\begin{array}{l}3 \\
1 \\
1 \\
N \\
5\end{array}$ & $\begin{array}{l}3-2-6 \\
35-3-6 \\
35-3-6 \\
11-37-106 \\
12-37-106\end{array}$ & $\begin{array}{l}\text { Do. } \\
\text { Do. } \\
\text { Do. } \\
\text { Dry Cr. } \\
\text { Do. }\end{array}$ \\
\hline $\begin{array}{l}906 \\
908 \\
912 \\
913 \\
914\end{array}$ & $\begin{array}{r}20 \\
L \\
15 \\
15 \\
L\end{array}$ & $\begin{array}{r}15 \\
15 \\
15 \\
5 \\
15\end{array}$ & $\begin{array}{r}L \\
L \\
N \\
N \\
100\end{array}$ & $\begin{array}{r}70 \\
70 \\
70 \\
50 \\
100\end{array}$ & $\begin{array}{l}20 \\
15 \\
30 \\
15 \\
30\end{array}$ & $\begin{array}{l}300 \\
100 \\
300 \\
150 \\
300\end{array}$ & $\begin{array}{l}3 \\
5 \\
3 \\
1 \\
3\end{array}$ & $\begin{array}{l}31-38-105 \\
30-38-105 \\
25-38-106 \\
25-38-106 \\
30-38-105\end{array}$ & $\begin{array}{l}\text { Do. } \\
\text { Do. } \\
\text { Do. } \\
\text { Do. } \\
\text { Do. }\end{array}$ \\
\hline $\begin{array}{l}919 \\
921 \\
934 \\
965 \\
968\end{array}$ & $\begin{array}{l}N \\
15 \\
20 \\
15 \\
30\end{array}$ & $\begin{array}{l}15 \\
10 \\
10 \\
10 \\
20\end{array}$ & $\begin{array}{r}L \\
N \\
100 \\
L \\
100\end{array}$ & $\begin{array}{r}70 \\
70 \\
100 \\
70 \\
100\end{array}$ & $\begin{array}{l}15 \\
15 \\
15 \\
20 \\
30\end{array}$ & $\begin{array}{l}150 \\
100 \\
100 \\
150 \\
700\end{array}$ & $\begin{array}{l}3 \\
3 \\
1 \\
5 \\
5\end{array}$ & $\begin{array}{r}31-38-105 \\
30-38-105 \\
26-37-106 \\
9-36-106 \\
15-36-106\end{array}$ & $\begin{array}{l}\text { Do. } \\
\text { Do. } \\
\text { Bull Lake Cr. } \\
\text { Do. } \\
\text { Do. }\end{array}$ \\
\hline $\begin{array}{r}985 \\
988 \\
996 \\
998 \\
1003\end{array}$ & $\begin{array}{l}20 \\
10 \\
20 \\
50 \\
70\end{array}$ & $\begin{array}{r}10 \\
L \\
7 \\
15 \\
15\end{array}$ & $\begin{array}{r}150 \\
100 \\
100 \\
200 \\
L\end{array}$ & $\begin{array}{r}50 \\
10 \\
50 \\
70 \\
100\end{array}$ & $\begin{array}{l}20 \\
10 \\
15 \\
20 \\
30\end{array}$ & $\begin{array}{r}200 \\
70 \\
100 \\
150 \\
150\end{array}$ & $\begin{array}{l}5 \\
14 \\
11 \\
14 \\
14\end{array}$ & $\begin{array}{r}28-36-106 \\
20-36-106 \\
4-35-106 \\
20-36-106 \\
19-37-105\end{array}$ & $\begin{array}{l}\text { Do. } \\
\text { Do. } \\
\text { Do. } \\
\text { Do. } \\
\text { Do. }\end{array}$ \\
\hline $\begin{array}{l}1021 \\
1022 \\
1023 \\
1025 \\
1036\end{array}$ & $\begin{array}{r}30 \\
15 \\
10 \\
70 \\
150\end{array}$ & $\begin{array}{r}7 \\
10 \\
\mathrm{~L} \\
7 \\
15\end{array}$ & $\begin{array}{r}L \\
100 \\
L \\
100 \\
100\end{array}$ & $\begin{array}{l}50 \\
70 \\
30 \\
50 \\
70\end{array}$ & $\begin{array}{l}20 \\
20 \\
15 \\
20 \\
30\end{array}$ & $\begin{array}{r}50 \\
100 \\
30 \\
50 \\
100\end{array}$ & $\begin{array}{l}8 \\
5 \\
5 \\
3 \\
3\end{array}$ & $\begin{array}{r}3-36-106 \\
1-36-106 \\
2-36-106 \\
12-35-106 \\
32-36-106\end{array}$ & $\begin{array}{l}\text { Do. } \\
\text { Do. } \\
\text { Do. } \\
\text { Do. } \\
\text { Do. }\end{array}$ \\
\hline
\end{tabular}


Semi quantitative spectrographic analyses

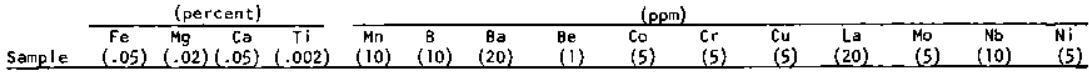

Organic silt samples--Continued

\begin{tabular}{|c|c|c|c|c|c|c|c|c|c|c|c|c|c|c|c|}
\hline $\begin{array}{l}1044 \\
1049 \\
1051 \\
1073\end{array}$ & $\begin{array}{l}3 \\
5 \\
5 \\
2\end{array}$ & $\begin{array}{r}1 \\
1.5 \\
1.5 \\
.3\end{array}$ & $\begin{array}{l}1 \\
1.5 \\
1.5 \\
.7\end{array}$ & $\begin{array}{r}0.3 \\
.3 \\
.3 \\
.2\end{array}$ & $\begin{array}{l}300 \\
300 \\
300 \\
150\end{array}$ & $\begin{array}{r}10 \\
N \\
N \\
10\end{array}$ & $\begin{array}{l}300 \\
300 \\
200 \\
300\end{array}$ & $\begin{array}{l}\mathrm{I} \\
\mathrm{L} \\
\mathrm{L} \\
\mathrm{L}\end{array}$ & $\begin{array}{r}15 \\
15 \\
15 \\
L\end{array}$ & $\begin{array}{r}70 \\
700 \\
300 \\
50\end{array}$ & $\begin{array}{r}10 \\
10 \\
15 \\
7\end{array}$ & $\begin{array}{r}100 \\
100 \\
150 \\
50\end{array}$ & $\begin{array}{l}\mathrm{N} \\
\mathrm{N} \\
\mathrm{N} \\
\mathrm{N}\end{array}$ & $\begin{array}{l}\mathrm{L} \\
\mathrm{L} \\
\mathrm{L}\end{array}$ & $\begin{array}{r}30 \\
100 \\
100 \\
15\end{array}$ \\
\hline \multicolumn{16}{|c|}{ Sand samples } \\
\hline $\begin{array}{l}117 \\
210 \\
211 \\
212 \\
213\end{array}$ & $\begin{array}{l}2 \\
2 \\
1.5 \\
1.5 \\
1.5\end{array}$ & $\begin{array}{r}1.5 \\
.5 \\
.3 \\
.2 \\
.3\end{array}$ & $\begin{array}{l}0.7 \\
.7 \\
.7 \\
.7 \\
.7\end{array}$ & $\begin{array}{r}0.2 \\
.2 \\
.2 \\
.15 \\
.15\end{array}$ & $\begin{array}{l}300 \\
200 \\
150 \\
150 \\
150\end{array}$ & $\begin{array}{l}\mathrm{L} \\
\mathrm{N} \\
\mathrm{N} \\
\mathrm{N} \\
\mathrm{N}\end{array}$ & $\begin{array}{l}200 \\
300 \\
300 \\
500 \\
300\end{array}$ & $\begin{array}{l}1 \\
1 \\
1 \\
1\end{array}$ & $\begin{array}{r}15 \\
7 \\
L \\
L \\
7\end{array}$ & $\begin{array}{l}70 \\
20 \\
15 \\
10 \\
10\end{array}$ & $\begin{array}{l}15 \\
10 \\
15 \\
10 \\
10\end{array}$ & $\begin{array}{r}30 \\
100 \\
50 \\
50 \\
50\end{array}$ & $\begin{array}{l}\mathbf{N} \\
\mathbf{N} \\
\mathbf{N} \\
\mathbf{N} \\
\mathbf{N}\end{array}$ & $\begin{array}{l}L \\
L \\
L \\
L\end{array}$ & $\begin{array}{l}30 \\
10 \\
10 \\
10 \\
15\end{array}$ \\
\hline $\begin{array}{l}214 \\
224 \\
228 \\
232 \\
233\end{array}$ & $\begin{array}{l}3 \\
1.5 \\
.7 \\
2\end{array}$ & $\begin{array}{l}1 \\
1 \\
.3 \\
.7 \\
.7\end{array}$ & $\begin{array}{l}1.5 \\
2 \\
.7 \\
.5 \\
.7\end{array}$ & $\begin{array}{l}.3 \\
.15 \\
.15 \\
.15 \\
.15\end{array}$ & $\begin{array}{r}300 \\
300 \\
50 \\
150 \\
200\end{array}$ & $\begin{array}{r}\mathrm{L} \\
30 \\
50 \\
\mathrm{~N} \\
\mathrm{~N}\end{array}$ & $\begin{array}{l}300 \\
500 \\
150 \\
300 \\
300\end{array}$ & $\begin{array}{l}1 \\
L \\
L \\
L \\
L\end{array}$ & $\begin{array}{r}15 \\
7 \\
\mathrm{~L} \\
10 \\
10\end{array}$ & $\begin{array}{l}70 \\
20 \\
20 \\
30 \\
50\end{array}$ & $\begin{array}{r}15 \\
7 \\
5 \\
5 \\
10\end{array}$ & $\begin{array}{l}50 \\
30 \\
20 \\
30 \\
30\end{array}$ & $\begin{array}{l}\mathbf{N} \\
\mathbf{N} \\
\mathbf{N} \\
\mathbf{N} \\
\mathbf{N}\end{array}$ & $\begin{array}{l}\mathrm{L} \\
\mathrm{L} \\
\mathrm{L} \\
\mathrm{L}\end{array}$ & $\begin{array}{r}70 \\
10 \\
5 \\
15 \\
15\end{array}$ \\
\hline $\begin{array}{l}240 \\
244 \\
245 \\
247 \\
253\end{array}$ & $\begin{array}{l}1.5 \\
3 \\
3 \\
3 \\
5\end{array}$ & $\begin{array}{l}1^{.3} \\
1.5 \\
1.5\end{array}$ & $\begin{array}{l}1^{.5} \\
1.5 \\
.7\end{array}$ & $\begin{array}{l}.15 \\
.3 \\
.2 \\
.3 \\
.3\end{array}$ & $\begin{array}{l}300 \\
500 \\
300 \\
500 \\
700\end{array}$ & $\begin{array}{l}\mathrm{L} \\
\mathrm{L} \\
\mathrm{L} \\
\mathrm{N}\end{array}$ & $\begin{array}{l}200 \\
300 \\
300 \\
300 \\
300\end{array}$ & $\begin{array}{l}\mathrm{L} \\
\mathrm{L} \\
\mathrm{L} \\
\mathrm{I} \\
\mathrm{I}\end{array}$ & $\begin{array}{r}7 \\
15 \\
15 \\
15 \\
20\end{array}$ & $\begin{array}{r}20 \\
150 \\
70 \\
200 \\
150\end{array}$ & $\begin{array}{l}7 \\
10 \\
15 \\
15 \\
15\end{array}$ & $\begin{array}{r}30 \\
100 \\
50 \\
200 \\
70\end{array}$ & $\begin{array}{l}\mathbf{N} \\
\mathbf{N} \\
\mathbf{N} \\
\mathrm{N} \\
\mathrm{N}\end{array}$ & $\begin{array}{r}\text { L } \\
\text { L } \\
\text { L } \\
20 \\
\text { L }\end{array}$ & $\begin{array}{r}10 \\
20 \\
20 \\
100 \\
70\end{array}$ \\
\hline $\begin{array}{l}254 \\
255 \\
256 \\
257 \\
258\end{array}$ & $\begin{array}{l}3 \\
2 \\
3 \\
3 \\
3\end{array}$ & $\begin{array}{l}.7 \\
.7 \\
.7 \\
.7 \\
.7\end{array}$ & $\begin{array}{l}1.5 \\
.7 \\
1 \\
1\end{array}$ & $\begin{array}{l}.3 \\
.3 \\
.2 \\
.2 \\
.2\end{array}$ & $\begin{array}{l}300 \\
700 \\
700 \\
700 \\
300\end{array}$ & $\begin{array}{r}L \\
20 \\
L \\
L\end{array}$ & $\begin{array}{l}200 \\
300 \\
500 \\
500 \\
200\end{array}$ & $\begin{array}{l}1 \\
1 \\
1 \\
1 \\
1.5\end{array}$ & $\begin{array}{l}15 \\
15 \\
15 \\
15\end{array}$ & $\begin{array}{l}N \\
30 \\
70 \\
70 \\
70\end{array}$ & $\begin{array}{l}15 \\
15 \\
10 \\
15 \\
15\end{array}$ & $\begin{array}{l}50 \\
30 \\
70 \\
50 \\
50\end{array}$ & $\begin{array}{l}\mathbf{N} \\
\mathbf{N} \\
\mathbf{N} \\
\mathbf{N} \\
\mathbf{N}\end{array}$ & $\begin{array}{l}\mathrm{L} \\
\mathrm{L} \\
\mathrm{L} \\
\mathrm{L} \\
\mathrm{L}\end{array}$ & $\begin{array}{l}15 \\
30 \\
20 \\
30 \\
20\end{array}$ \\
\hline $\begin{array}{l}260 \\
262 \\
263 \\
264 \\
265\end{array}$ & $\begin{array}{l}2 \\
5 \\
3 \\
3 \\
1.5\end{array}$ & $\begin{array}{l}1.7 \\
1.5 \\
1.5\end{array}$ & $\begin{array}{l}1.5 \\
1.7 \\
1 \\
1\end{array}$ & $\begin{array}{l}.2 \\
.3 \\
.3 \\
.3 \\
.3\end{array}$ & $\begin{array}{l}150 \\
300 \\
500 \\
500 \\
150\end{array}$ & $\begin{array}{l}N \\
L \\
N \\
L \\
N\end{array}$ & $\begin{array}{l}500 \\
500 \\
300 \\
300 \\
500\end{array}$ & $\begin{array}{l}1 \\
\mathrm{~L} \\
1 \\
1 \\
1\end{array}$ & $\begin{array}{r}10 \\
20 \\
15 \\
20 \\
5\end{array}$ & $\begin{array}{r}30 \\
300 \\
30 \\
50 \\
50\end{array}$ & $\begin{array}{r}10 \\
15 \\
15 \\
150 \\
15\end{array}$ & $\begin{array}{r}100 \\
100 \\
150 \\
50 \\
70\end{array}$ & $\begin{array}{l}\mathbf{N} \\
\mathbf{N} \\
\mathbf{N} \\
\mathrm{N} \\
\mathrm{N}\end{array}$ & $\begin{array}{r}\text { L } \\
\text { L } \\
10 \\
15 \\
\text { L }\end{array}$ & $\begin{array}{r}7 \\
15 \\
20 \\
30 \\
5\end{array}$ \\
\hline $\begin{array}{l}267 \\
268 \\
269 \\
270 \\
272\end{array}$ & $\begin{array}{l}2 \\
1.5 \\
5 \\
3 \\
2\end{array}$ & $\begin{array}{r}.5 \\
.7 \\
1.5 \\
.7 \\
.7\end{array}$ & $\begin{array}{r}.5 \\
.7 \\
.7 \\
.7\end{array}$ & $\begin{array}{l}.2 \\
.2 \\
.5 \\
.3 \\
.2\end{array}$ & $\begin{array}{l}300 \\
150 \\
700 \\
300 \\
500\end{array}$ & $\begin{array}{r}70 \\
50 \\
N \\
30 \\
N\end{array}$ & $\begin{array}{l}500 \\
700 \\
300 \\
300 \\
200\end{array}$ & $\begin{array}{l}2 \\
1.5 \\
1 \\
1\end{array}$ & $\begin{array}{l}10 \\
10 \\
15 \\
10 \\
10\end{array}$ & $\begin{array}{l}70 \\
20 \\
70 \\
30 \\
30\end{array}$ & $\begin{array}{r}15 \\
10 \\
15 \\
20 \\
7\end{array}$ & $\begin{array}{l}30 \\
30 \\
50 \\
70 \\
50\end{array}$ & $\begin{array}{r}\mathbf{N} \\
\mathbf{N} \\
\mathrm{N} \\
10 \\
\mathrm{~N}\end{array}$ & $\begin{array}{r}\text { L } \\
\text { L } \\
\text { L } \\
10 \\
\text { L }\end{array}$ & $\begin{array}{r}5 \\
7 \\
20 \\
15 \\
10\end{array}$ \\
\hline $\begin{array}{l}274 \\
275 \\
276 \\
277 \\
278\end{array}$ & $\begin{array}{l}3 \\
1.5 \\
1.5 \\
1.5 \\
1.5\end{array}$ & $\begin{array}{r}1.5 \\
.7 \\
.7 \\
.5 \\
.7\end{array}$ & $\begin{array}{l}1.5 \\
1 \\
1 \\
1 \\
1\end{array}$ & $\begin{array}{l}.2 \\
.15 \\
.15 \\
.3 \\
.15\end{array}$ & $\begin{array}{l}500 \\
200 \\
150 \\
150 \\
150\end{array}$ & $\begin{array}{l}\mathbf{N} \\
\mathbf{N} \\
\mathbf{N} \\
\mathbf{N} \\
\mathbf{N}\end{array}$ & $\begin{array}{l}300 \\
300 \\
500 \\
300 \\
300\end{array}$ & $\begin{array}{l}1 \\
1.5 \\
1 \\
1 \\
1\end{array}$ & $\begin{array}{r}15 \\
5 \\
5 \\
5 \\
5\end{array}$ & $\begin{array}{r}50 \\
30 \\
150 \\
70 \\
50\end{array}$ & $\begin{array}{r}15 \\
7 \\
\mathrm{~L} \\
15 \\
15\end{array}$ & $\begin{array}{l}70 \\
50 \\
70 \\
70 \\
50\end{array}$ & $\begin{array}{l}N \\
N \\
N \\
N \\
N\end{array}$ & $\begin{array}{r}\mathrm{L} \\
\mathrm{L} \\
\mathrm{N} \\
10 \\
\mathrm{~L}\end{array}$ & $\begin{array}{l}15 \\
10 \\
10 \\
10 \\
10\end{array}$ \\
\hline $\begin{array}{l}279 \\
280 \\
281 \\
283 \\
285\end{array}$ & $\begin{array}{r}3 \\
.5 \\
.7 \\
1.5 \\
1.5\end{array}$ & $\begin{array}{l}.7 \\
.3 \\
.5 \\
.3 \\
.7\end{array}$ & $\begin{array}{r}1.5 \\
.7 \\
.7 \\
.7\end{array}$ & $\begin{array}{l}.3 \\
.07 \\
.15 \\
.15 \\
.3\end{array}$ & $\begin{array}{l}300 \\
100 \\
200 \\
300 \\
200\end{array}$ & $\begin{array}{r}N \\
50 \\
N \\
N \\
N\end{array}$ & $\begin{array}{l}300 \\
150 \\
300 \\
300 \\
300\end{array}$ & $\begin{array}{l}\text { I } \\
1 \\
L \\
1 \\
1\end{array}$ & $\begin{array}{l}7 \\
\mathrm{~N} \\
\mathrm{~L} \\
\mathrm{~N} \\
7\end{array}$ & $\begin{array}{l}70 \\
20 \\
15 \\
15 \\
30\end{array}$ & $\begin{array}{l}15 \\
10 \\
15 \\
15 \\
15\end{array}$ & $\begin{array}{r}150 \\
\mathrm{~L} \\
30 \\
70 \\
70\end{array}$ & $\begin{array}{l}\mathbf{N} \\
\mathbf{N} \\
\mathbf{N} \\
\mathbf{N} \\
\mathbf{N}\end{array}$ & $\begin{array}{r}\mathrm{L} \\
\mathbf{N} \\
\mathrm{N} \\
\mathrm{L} \\
10\end{array}$ & $\begin{array}{r}15 \\
\mathrm{~L} \\
7 \\
\mathrm{~L} \\
10\end{array}$ \\
\hline $\begin{array}{l}287 \\
289 \\
291 \\
293 \\
294\end{array}$ & $\begin{array}{l}1 \\
1.5 \\
1 \\
1 \\
3\end{array}$ & $\begin{array}{l}.7 \\
.5 \\
.5 \\
.3 \\
.1\end{array}$ & $\begin{array}{l}1.5 \\
1 \\
1 \\
1 \\
1.5\end{array}$ & $\begin{array}{l}.3 \\
.2 \\
.1 \\
.3 \\
.7\end{array}$ & $\begin{array}{r}200 \\
1,500 \\
150 \\
150 \\
700\end{array}$ & $\begin{array}{l}\mathbf{N} \\
\mathbf{N} \\
\mathbf{N} \\
\mathbf{N} \\
\mathbf{N}\end{array}$ & $\begin{array}{l}300 \\
200 \\
300 \\
300 \\
150\end{array}$ & $\begin{array}{l}1 \\
\mathrm{~L} \\
1.5 \\
1 \\
1\end{array}$ & $\begin{array}{r}5 \\
5 \\
7 \\
5 \\
10\end{array}$ & $\begin{array}{r}50 \\
100 \\
30 \\
20 \\
70\end{array}$ & $\begin{array}{l}15 \\
10 \\
30 \\
15 \\
15\end{array}$ & $\begin{array}{r}150 \\
30 \\
50 \\
70 \\
70\end{array}$ & $\begin{array}{l}\mathbf{N} \\
\mathbf{N} \\
\mathbf{N} \\
\mathbf{N} \\
\mathbf{N}\end{array}$ & $\begin{array}{l}\mathrm{L} \\
\mathrm{L} \\
\mathrm{L} \\
\mathrm{L} \\
15\end{array}$ & $\begin{array}{r}10 \\
7 \\
7 \\
7 \\
15\end{array}$ \\
\hline $\begin{array}{l}296 \\
301 \\
313 \\
315 \\
317\end{array}$ & $\begin{array}{l}5 \\
2 \\
5 \\
5 \\
5\end{array}$ & ${ }_{1}^{2} .7$ & $\begin{array}{l}1.5 \\
5 \\
1.5 \\
1.5 \\
1\end{array}$ & $\begin{array}{l}.5 \\
.15 \\
.15 \\
.15 \\
.3\end{array}$ & $\begin{array}{l}700 \\
300 \\
500 \\
500 \\
700\end{array}$ & $\begin{array}{r}N \\
30 \\
30 \\
50 \\
L\end{array}$ & $\begin{array}{l}300 \\
500 \\
500 \\
500 \\
300\end{array}$ & $\begin{array}{l}L \\
1 \\
L \\
1\end{array}$ & $\begin{array}{l}30 \\
10 \\
15 \\
15 \\
15\end{array}$ & $\begin{array}{r}300 \\
50 \\
70 \\
50 \\
200\end{array}$ & $\begin{array}{l}70 \\
10 \\
15 \\
15 \\
20\end{array}$ & $\begin{array}{r}200 \\
30 \\
30 \\
30 \\
100\end{array}$ & $\begin{array}{l}\mathrm{N} \\
\mathrm{N} \\
\mathrm{N} \\
\mathrm{N} \\
\mathrm{N}\end{array}$ & $\begin{array}{l}L \\
L \\
L \\
L \\
10\end{array}$ & $\begin{array}{r}100 \\
15 \\
15 \\
15 \\
70\end{array}$ \\
\hline $\begin{array}{l}319 \\
321 \\
324 \\
325 \\
328\end{array}$ & $\begin{array}{l}3 \\
2 \\
2 \\
3 \\
1.5\end{array}$ & $\begin{array}{l}.7 \\
.5 \\
.7 \\
.5 \\
.5\end{array}$ & $\begin{array}{l}1.7 \\
1.5 \\
1.5 \\
1.5\end{array}$ & $\begin{array}{l}.15 \\
.2 \\
.15 \\
.3 \\
.2\end{array}$ & $\begin{array}{l}300 \\
300 \\
200 \\
200 \\
150\end{array}$ & $\begin{array}{l}\text { L } \\
N \\
\text { L } \\
L\end{array}$ & $\begin{array}{l}500 \\
300 \\
300 \\
500 \\
500\end{array}$ & $\begin{array}{l}1.5 \\
1 \\
\mathrm{~L} \\
1 \\
\mathrm{~L}\end{array}$ & $\begin{array}{l}5 \\
10 \\
10 \\
10 \\
10\end{array}$ & $\begin{array}{r}50 \\
20 \\
150 \\
50 \\
70\end{array}$ & $\begin{array}{r}10 \\
7 \\
5 \\
10 \\
7\end{array}$ & $\begin{array}{l}70 \\
30 \\
30 \\
70 \\
50\end{array}$ & $\begin{array}{l}\mathbf{N} \\
\mathbf{N} \\
\mathrm{N} \\
\mathrm{N} \\
\mathrm{N}\end{array}$ & $\begin{array}{l}\mathrm{L} \\
\mathrm{L} \\
\mathrm{L} \\
\mathrm{L} \\
\mathrm{L}\end{array}$ & $\begin{array}{r}10 \\
15 \\
70 \\
5 \\
20\end{array}$ \\
\hline
\end{tabular}


Semiquantitative spectrographic analyses--Continued

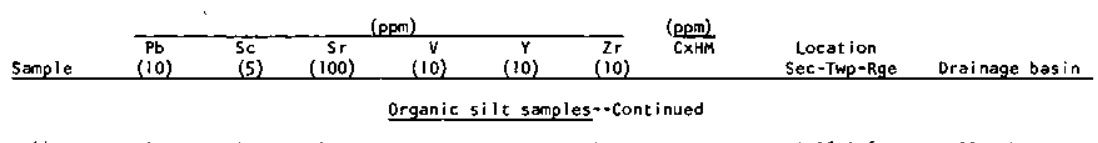

$\begin{array}{llllllllll}1044 & 30 & 10 & 150 & 70 & 70 & 100 & 7 & 21-36-106 & \text { Bull Lake Cr. } \\ 1049 & 20 & 15 & 150 & 70 & 20 & 100 & 1 & 30-38-105 & \text { Ory Cr. } \\ 1051 & 20 & 15 & 100 & 70 & 30 & 100 & 3 & 20-38-105 & \text { Do. } \\ 1073 & 15 & 10 & 150 & 70 & 15 & 200 & 3 & 10-35-106 & \text { Bul1 Lake Cr. }\end{array}$

\section{Sand samples}

\begin{tabular}{|c|c|c|c|c|c|}
\hline $\begin{array}{l}117 \\
210 \\
211 \\
212 \\
213\end{array}$ & $\begin{array}{l}30 \\
70 \\
15 \\
15 \\
30\end{array}$ & $\begin{array}{l}7 \\
7 \\
5 \\
L \\
5\end{array}$ & $\begin{array}{r}\mathrm{L} \\
100 \\
100 \\
\mathrm{~L} \\
100\end{array}$ & $\begin{array}{l}50 \\
30 \\
20 \\
15 \\
20\end{array}$ & $\begin{array}{l}30 \\
30 \\
30 \\
15 \\
20\end{array}$ \\
\hline $\begin{array}{l}214 \\
224 \\
228 \\
232 \\
233\end{array}$ & $\begin{array}{r}50 \\
15 \\
L \\
15 \\
15\end{array}$ & $\begin{array}{r}10 \\
5 \\
5 \\
7 \\
7\end{array}$ & $\begin{array}{r}150 \\
\mathbf{N} \\
\mathbf{N} \\
100 \\
100\end{array}$ & $\begin{array}{l}70 \\
20 \\
15 \\
20 \\
20\end{array}$ & $\begin{array}{l}30 \\
20 \\
15 \\
20 \\
20\end{array}$ \\
\hline $\begin{array}{l}240 \\
244 \\
245 \\
247 \\
253\end{array}$ & $\begin{array}{l}30 \\
50 \\
20 \\
50 \\
20\end{array}$ & $\begin{array}{r}5 \\
10 \\
10 \\
10 \\
10\end{array}$ & $\begin{array}{r}N \\
100 \\
L \\
100 \\
L\end{array}$ & $\begin{array}{l}30 \\
50 \\
50 \\
70 \\
70\end{array}$ & $\begin{array}{r}20 \\
70 \\
50 \\
150 \\
50\end{array}$ \\
\hline $\begin{array}{l}254 \\
255 \\
256 \\
257 \\
258\end{array}$ & $\begin{array}{l}15 \\
15 \\
15 \\
15 \\
20\end{array}$ & $\begin{array}{r}10 \\
10 \\
7 \\
10 \\
7\end{array}$ & $\begin{array}{r}100 \\
N \\
100 \\
100 \\
150\end{array}$ & $\begin{array}{l}70 \\
70 \\
70 \\
70 \\
50\end{array}$ & $\begin{array}{l}15 \\
20 \\
30 \\
30 \\
15\end{array}$ \\
\hline $\begin{array}{r}260 \\
262 \\
-253 \\
264 \\
265\end{array}$ & $\begin{array}{l}15 \\
50 \\
30 \\
70 \\
15\end{array}$ & $\begin{array}{r}7 \\
7 \\
10 \\
10 \\
5\end{array}$ & $\begin{array}{l}200 \\
100 \\
100 \\
100 \\
100\end{array}$ & $\begin{array}{l}20 \\
50 \\
70 \\
50 \\
20\end{array}$ & $\begin{array}{l}30 \\
30 \\
50 \\
50 \\
20\end{array}$ \\
\hline $\begin{array}{l}267 \\
268 \\
269 \\
270 \\
272\end{array}$ & $\begin{array}{l}15 \\
15 \\
15 \\
20 \\
30\end{array}$ & $\begin{array}{r}7 \\
7 \\
10 \\
5 \\
5\end{array}$ & $\begin{array}{r}L \\
L \\
200 \\
100 \\
L\end{array}$ & $\begin{array}{r}20 \\
30 \\
100 \\
70 \\
30\end{array}$ & $\begin{array}{l}20 \\
30 \\
30 \\
30 \\
20\end{array}$ \\
\hline $\begin{array}{l}274 \\
275 \\
276 \\
277 \\
278\end{array}$ & $\begin{array}{l}20 \\
10 \\
15 \\
15 \\
15\end{array}$ & $\begin{array}{r}10 \\
7 \\
5 \\
7 \\
5\end{array}$ & $\begin{array}{l}150 \\
200 \\
200 \\
150 \\
150\end{array}$ & $\begin{array}{l}50 \\
20 \\
20 \\
30 \\
30\end{array}$ & $\begin{array}{l}30 \\
30 \\
30 \\
30 \\
30\end{array}$ \\
\hline $\begin{array}{l}279 \\
280 \\
281 \\
283 \\
285\end{array}$ & $\begin{array}{l}15 \\
10 \\
10 \\
15 \\
15\end{array}$ & $\begin{array}{r}10 \\
\text { L } \\
5 \\
5 \\
7\end{array}$ & $\begin{array}{r}100 \\
N \\
100 \\
150 \\
150\end{array}$ & $\begin{array}{l}30 \\
10 \\
15 \\
20 \\
30\end{array}$ & $\begin{array}{r}100 \\
15 \\
15 \\
20 \\
30\end{array}$ \\
\hline $\begin{array}{l}287 \\
289 \\
291 \\
293 \\
294\end{array}$ & $\begin{array}{l}15 \\
10 \\
15 \\
15 \\
30\end{array}$ & $\begin{array}{r}5 \\
5 \\
15 \\
5 \\
20\end{array}$ & $\begin{array}{r}150 \\
L \\
150 \\
150 \\
100\end{array}$ & $\begin{array}{l}20 \\
15 \\
15 \\
20 \\
70\end{array}$ & $\begin{array}{l}30 \\
20 \\
20 \\
20 \\
50\end{array}$ \\
\hline $\begin{array}{l}296 \\
301 \\
313 \\
315 \\
317\end{array}$ & $\begin{array}{l}30 \\
50 \\
15 \\
15 \\
70\end{array}$ & $\begin{array}{r}20 \\
5 \\
7 \\
7 \\
15\end{array}$ & $\begin{array}{r}150 \\
100 \\
L \\
L \\
L\end{array}$ & $\begin{array}{r}150 \\
20 \\
20 \\
30 \\
70\end{array}$ & $\begin{array}{r}30 \\
15 \\
15 \\
30 \\
100\end{array}$ \\
\hline $\begin{array}{l}319 \\
321 \\
324 \\
325 \\
328\end{array}$ & $\begin{array}{l}30 \\
30 \\
10 \\
10 \\
10\end{array}$ & $\begin{array}{l}5 \\
7 \\
7 \\
7 \\
7\end{array}$ & $\begin{array}{r}100 \\
L \\
150 \\
100 \\
150\end{array}$ & $\begin{array}{l}30 \\
20 \\
20 \\
30 \\
20\end{array}$ & $\begin{array}{l}15 \\
70 \\
15 \\
50 \\
20\end{array}$ \\
\hline
\end{tabular}

$150 \quad 11-38-106$

$8-38-106$

$14-38-107$

$14-38-107$

$13-38-107$

13-38-107

34-40-106

25-40-106

15-39-107

$14-39-107$

$21-40-107$

$16-40-107$

$10-40-107$

$10-40-107$

33-41-107

10-40-107

31-41-107

$32-41-107$

$32-41-107$

$4-38-106$

35-38- 107

25-38-107

25-38-107

$30-38-106$

29-38-106

$12-39-106$

6-39-105

20-38- 106

$29-38-106$

28-38-106

20-38-106

24-39-106

19-39-105

19-39-105

20-39-105

$20-39-105$
$21-39-105$

$21-39-105$

$21-39-105$

2-38-106

2-38-106

2-38-106

35-39-106

$26-39-106$

7-39-107

12-39-108

$13-40-106$

33-41-106

33-41-106

8-37-106

7-38-106

8-38-106

7-37-106

$6-37-106$

5-37-106
Dinwoody $\mathrm{Cr}$.

Do.

Do.

Do.

Do.

Do.

Blue Hole $\mathrm{Cr}$. Do.

Torrey $\mathrm{Cr}$.

Do.

Jakeys Fork.

Do.

Do.

Do.

Do

Do

Dinwoody $\mathrm{Cr}$.

Do.

Do.

Do.

Do.

Red $\mathrm{Cr}$.

Dinwoody $\mathrm{Cr}$.

Do.

Do.

Do.

Do.

Do.

Do.

Do.

Do.

Do.

Do.

Do.

Do.

Roaring Fork.

Do.

Torrey $\mathrm{Cr}$.

Do.

Di nwoody Cr.

Do

Do.

Do.

Do. 
Semiquantitative spectrographic analyses

\begin{tabular}{|c|c|c|c|c|c|c|c|c|c|c|c|c|c|c|c|}
\hline \multirow[b]{2}{*}{ Semple } & \multicolumn{4}{|c|}{ (percent) } & \multicolumn{9}{|c|}{ (ppm) } & \multirow[b]{2}{*}{$\begin{array}{l}\mathrm{Nb} \\
(10)\end{array}$} & \\
\hline & $\begin{array}{c}\mathrm{Fe} \\
(.05)\end{array}$ & $\begin{array}{c}\mathrm{Mg} \\
(.02)\end{array}$ & $\begin{array}{c}\mathrm{Ca} \\
(.05)\end{array}$ & $\begin{array}{c}\mathrm{Ti} \\
(.002)\end{array}$ & $\begin{array}{l}M n \\
(10)\end{array}$ & $\begin{array}{c}8 \\
(10) \\
\end{array}$ & $\begin{array}{c}8 \mathrm{Ba} \\
(20)\end{array}$ & $\begin{array}{l}\text { Be } \\
\text { (1) }\end{array}$ & $\begin{array}{l}\text { Co } \\
(5)\end{array}$ & $\begin{array}{l}c r \\
(5)\end{array}$ & $\begin{array}{l}C u \\
(5)\end{array}$ & $\begin{array}{l}\text { La } \\
\text { (20) }\end{array}$ & $\begin{array}{l}\text { Mo } \\
\text { (5) }\end{array}$ & & $\begin{array}{l}\mathrm{Ni} \\
(5)\end{array}$ \\
\hline
\end{tabular}

Sand Samples--Continued

\begin{tabular}{|c|c|c|c|c|c|c|c|c|c|c|c|c|c|c|}
\hline $\begin{array}{l}329 \\
330 \\
331 \\
333 \\
337\end{array}$ & $\begin{array}{l}1.5 \\
3 \\
2 \\
2 \\
3\end{array}$ & $\begin{array}{r}0.5 \\
.7 \\
.7 \\
.7 \\
1.7\end{array}$ & $\begin{array}{l}0.7 \\
1 \\
1.5 \\
1.5\end{array}$ & $\begin{array}{c}0.2 \\
.7 \\
.2 \\
.2 \\
.15\end{array}$ & $\begin{array}{l}300 \\
300 \\
200 \\
300 \\
500\end{array}$ & $\begin{array}{c}10 \\
L \\
L \\
K \\
L\end{array}$ & $\begin{array}{l}100 \\
200 \\
500 \\
300 \\
200\end{array}$ & $\begin{array}{l}1 \\
\mathrm{~L} \\
\mathrm{~L} \\
1 \\
\mathrm{~L}\end{array}$ & $\begin{array}{l}7 \\
15 \\
15 \\
15 \\
15\end{array}$ & $\begin{array}{r}50 \\
100 \\
100 \\
100 \\
300\end{array}$ & $\begin{array}{l}15 \\
15 \\
15 \\
15 \\
20\end{array}$ & $\begin{array}{r}30 \\
150 \\
50 \\
50 \\
30\end{array}$ & $\begin{array}{l}\mathrm{N} \\
\mathrm{N} \\
\mathrm{N} \\
\mathrm{N} \\
\mathrm{N}\end{array}$ & $\begin{array}{r}\text { L } \\
15 \\
\text { L } \\
\text { L } \\
\text { L }\end{array}$ \\
\hline $\begin{array}{l}339 \\
342 \\
343 \\
346 \\
347\end{array}$ & $\begin{array}{l}3 \\
3 \\
3 \\
2 \\
2\end{array}$ & $\begin{array}{l}1 \\
.7 \\
.7 \\
.7\end{array}$ & $\begin{array}{l}1.5 \\
.7 \\
.7 \\
.7\end{array}$ & $\begin{array}{l}.2 \\
.15 \\
.15 \\
.15 \\
.15\end{array}$ & $\begin{array}{l}300 \\
300 \\
300 \\
200 \\
200\end{array}$ & $\begin{array}{l}\mathrm{L} \\
\mathrm{L} \\
\mathrm{N} \\
\mathrm{N}\end{array}$ & $\begin{array}{l}300 \\
200 \\
500 \\
300 \\
300\end{array}$ & $\begin{array}{l}1 \\
1.5 \\
1 \\
1 \\
4\end{array}$ & $\begin{array}{l}20 \\
20 \\
15 \\
15 \\
10\end{array}$ & $\begin{array}{l}70 \\
70 \\
70 \\
50 \\
15\end{array}$ & $\begin{array}{l}30 \\
30 \\
10 \\
20 \\
10\end{array}$ & $\begin{array}{r}70 \\
70 \\
100 \\
50 \\
50\end{array}$ & $\begin{array}{l}\mathrm{N} \\
\mathrm{N} \\
\mathrm{N} \\
\mathrm{N} \\
\mathrm{N}\end{array}$ & $\begin{array}{l}\mathrm{L} \\
\mathrm{L} \\
\mathrm{L} \\
\mathrm{L} \\
\mathrm{L}\end{array}$ \\
\hline $\begin{array}{l}348 \\
349 \\
350 \\
351 \\
353\end{array}$ & $\begin{array}{l}3 \\
2 \\
3 \\
2 \\
1.5\end{array}$ & $\begin{array}{l}1 \\
.7 \\
.7 \\
.7 \\
.3\end{array}$ & $\begin{array}{l}.5 \\
.5 \\
.7 \\
.7 \\
.5\end{array}$ & $\begin{array}{l}.15 \\
.15 \\
.3 \\
.2 \\
.1\end{array}$ & $\begin{array}{l}150 \\
300 \\
300 \\
300 \\
200\end{array}$ & $\begin{array}{l}N \\
L \\
N \\
L \\
L\end{array}$ & $\begin{array}{l}300 \\
300 \\
500 \\
300 \\
200\end{array}$ & $\begin{array}{l}\mathrm{L} \\
\mathbf{1} \\
\mathbf{1} \\
1 \\
\mathrm{~L}\end{array}$ & $\begin{array}{l}10 \\
10 \\
15 \\
15 \\
7\end{array}$ & $\begin{array}{l}50 \\
30 \\
70 \\
70 \\
30\end{array}$ & $\begin{array}{r}15 \\
20 \\
7 \\
10 \\
10\end{array}$ & $\begin{array}{l}70 \\
70 \\
70 \\
50 \\
30\end{array}$ & $\begin{array}{l}\mathrm{N} \\
\mathrm{N} \\
\mathrm{N} \\
\mathrm{N} \\
\mathrm{N}\end{array}$ & $\begin{array}{l}\text { L } \\
\text { L } \\
\text { L } \\
\text { L } \\
\text { L }\end{array}$ \\
\hline $\begin{array}{l}356 \\
357 \\
358 \\
359 \\
360\end{array}$ & $\begin{array}{l}3 \\
1.5 \\
3 \\
2 \\
1.5\end{array}$ & $\begin{array}{l}.7 \\
.7 \\
.7 \\
.7 \\
.5\end{array}$ & $\begin{array}{r}.7 \\
.7 \\
.7 \\
.3\end{array}$ & $\begin{array}{l}.5 \\
.3 \\
.3 \\
.2 \\
.1\end{array}$ & $\begin{array}{l}300 \\
200 \\
300 \\
300 \\
150\end{array}$ & $\begin{array}{r}10 \\
L \\
L \\
10 \\
N\end{array}$ & $\begin{array}{l}300 \\
500 \\
500 \\
300 \\
300\end{array}$ & $\begin{array}{l}1 \\
1 \\
1 \\
1 \\
1\end{array}$ & $\begin{array}{r}15 \\
7 \\
15 \\
15 \\
10\end{array}$ & $\begin{array}{l}70 \\
30 \\
50 \\
50 \\
20\end{array}$ & $\begin{array}{r}7 \\
L \\
15 \\
15 \\
10\end{array}$ & $\begin{array}{r}150 \\
20 \\
50 \\
150 \\
50\end{array}$ & $\begin{array}{l}N \\
N \\
N \\
N \\
N\end{array}$ & $\begin{array}{r}10 \\
\mathrm{~L} \\
\mathrm{~L} \\
\mathrm{~L} \\
\mathrm{~N}\end{array}$ \\
\hline $\begin{array}{l}361 \\
362 \\
365 \\
366 \\
367\end{array}$ & $\begin{array}{l}2 \\
3 \\
3 \\
3 \\
2\end{array}$ & $\begin{array}{l}.7 \\
.5 \\
.7 \\
.7 \\
.5\end{array}$ & $\begin{array}{l}.3 \\
.3 \\
.7 \\
.7\end{array}$ & $\begin{array}{l}.1 \\
.15 \\
.2 \\
.5 \\
.2\end{array}$ & $\begin{array}{l}200 \\
150 \\
300 \\
500 \\
300\end{array}$ & $\begin{array}{r}\mathrm{L} \\
\mathrm{N} \\
\mathrm{L} \\
15 \\
30\end{array}$ & $\begin{array}{l}500 \\
300 \\
150 \\
200 \\
300\end{array}$ & $\begin{array}{l}i \\
\text { L } \\
\text { L } \\
1\end{array}$ & $\begin{array}{l}10 \\
10 \\
15 \\
15 \\
15\end{array}$ & $\begin{array}{l}20 \\
30 \\
50 \\
70 \\
30\end{array}$ & $\begin{array}{r}15 \\
7 \\
10 \\
15 \\
15\end{array}$ & $\begin{array}{r}70 \\
100 \\
30 \\
150 \\
30\end{array}$ & $\begin{array}{l}\mathbf{N} \\
\mathbf{N} \\
\mathbf{N} \\
\mathbf{N} \\
\mathbf{N}\end{array}$ & $\begin{array}{l}\text { L } \\
\text { N } \\
\text { L } \\
\text { L } \\
\text { L }\end{array}$ \\
\hline $\begin{array}{l}368 \\
369 \\
370 \\
372 \\
376\end{array}$ & $\begin{array}{l}2 \\
1.5 \\
2 \\
2 \\
3\end{array}$ & $\begin{array}{l}.7 \\
.7 \\
.5 \\
1 \\
1\end{array}$ & $\begin{array}{l}.7 \\
.7 \\
.7 \\
1\end{array}$ & $\begin{array}{l}.3 \\
.3 \\
.2 \\
.3 \\
.2\end{array}$ & $\begin{array}{l}200 \\
300 \\
150 \\
200 \\
300\end{array}$ & $\begin{array}{c}N \\
N \\
N \\
N \\
N\end{array}$ & $\begin{array}{l}200 \\
150 \\
300 \\
300 \\
150\end{array}$ & $\begin{array}{l}1 \\
L \\
1 \\
1 \\
1\end{array}$ & $\begin{array}{r}15 \\
10 \\
5 \\
20 \\
20\end{array}$ & $\begin{array}{r}30 \\
20 \\
15 \\
70 \\
100\end{array}$ & $\begin{array}{l}15 \\
10 \\
15 \\
15 \\
10\end{array}$ & $\begin{array}{l}50 \\
50 \\
70 \\
50 \\
20\end{array}$ & $\begin{array}{l}\mathbf{N} \\
\mathbf{N} \\
\mathbf{N} \\
\mathbf{N} \\
\mathbf{N}\end{array}$ & $\begin{array}{l}\text { L } \\
\text { L } \\
\text { L } \\
\text { L } \\
\text { L }\end{array}$ \\
\hline $\begin{array}{l}377 \\
378 \\
379 \\
383 \\
385\end{array}$ & $\begin{array}{l}3 \\
3 \\
2 \\
3 \\
1\end{array}$ & $\begin{array}{r}.7 \\
1^{.7} \\
.3\end{array}$ & $\begin{array}{l}1.5 \\
1.5 \\
1 \\
1 \\
1\end{array}$ & $\begin{array}{l}.3 \\
.3 \\
.2 \\
.3 \\
.15\end{array}$ & $\begin{array}{l}500 \\
300 \\
300 \\
700 \\
100\end{array}$ & $\begin{array}{l}\mathrm{L} \\
N \\
\mathrm{~L} \\
N\end{array}$ & $\begin{array}{l}200 \\
200 \\
300 \\
300 \\
300\end{array}$ & $\begin{array}{l}1.5 \\
1 \\
1 \\
1 \\
L\end{array}$ & $\begin{array}{r}20 \\
20 \\
15 \\
20 \\
5\end{array}$ & $\begin{array}{l}70 \\
70 \\
70 \\
70 \\
15\end{array}$ & $\begin{array}{l}15 \\
15 \\
15 \\
20 \\
10\end{array}$ & $\begin{array}{r}20 \\
30 \\
70 \\
100 \\
30\end{array}$ & $\begin{array}{l}\mathbf{N} \\
\mathbf{N} \\
\mathbf{N} \\
\mathbf{N}\end{array}$ & $\begin{array}{r}L \\
10 \\
L \\
L \\
L\end{array}$ \\
\hline $\begin{array}{l}387 \\
389 \\
391 \\
392 \\
394\end{array}$ & $\begin{array}{l}1.5 \\
2^{.7} \\
2 \\
3\end{array}$ & $\begin{array}{l}.5 \\
.5 \\
.3 \\
.7 \\
.7\end{array}$ & $3_{1}^{.7}$ & $\begin{array}{l}.15 \\
.15 \\
.2 \\
.15 \\
.3\end{array}$ & $\begin{array}{l}150 \\
150 \\
150 \\
300 \\
300\end{array}$ & $\begin{array}{r}N \\
N \\
70 \\
100 \\
10\end{array}$ & $\begin{array}{l}300 \\
300 \\
500 \\
700 \\
500\end{array}$ & $\begin{array}{l}1 \\
1 \\
1.5 \\
1 \\
1\end{array}$ & $\begin{array}{c}5 \\
L \\
10 \\
15 \\
15\end{array}$ & $\begin{array}{r}30 \\
30 \\
70 \\
70 \\
100\end{array}$ & $\begin{array}{r}10 \\
5 \\
15 \\
15 \\
15\end{array}$ & $\begin{array}{r}20 \\
30 \\
50 \\
30 \\
100\end{array}$ & $\begin{array}{l}\mathbf{N} \\
\mathbf{N} \\
\mathbf{N} \\
\mathbf{N} \\
\mathbf{N}\end{array}$ & $\begin{array}{l}\mathrm{L} \\
\mathrm{L} \\
\mathrm{L} \\
\mathrm{L} \\
\mathrm{L}\end{array}$ \\
\hline $\begin{array}{l}396 \\
399 \\
400 \\
605 \\
609\end{array}$ & $\begin{array}{l}3 \\
3 \\
3 \\
3 \\
3\end{array}$ & $\begin{array}{l}1.5 \\
1.5 \\
1.5 \\
1 \\
1.5\end{array}$ & $\begin{array}{l}1.5 \\
1.5 \\
1.5 \\
1.5 \\
1.5\end{array}$ & $\begin{array}{l}.5 \\
.3 \\
.5 \\
.3 \\
.5\end{array}$ & $\begin{array}{r}700 \\
700 \\
1,500 \\
300 \\
500\end{array}$ & $\begin{array}{l}N \\
N \\
N \\
N \\
N\end{array}$ & $\begin{array}{l}200 \\
300 \\
200 \\
300 \\
300\end{array}$ & $\begin{array}{l}1.5 \\
1 \\
1.5 \\
2 \\
1.5\end{array}$ & $\begin{array}{l}15 \\
15 \\
15 \\
20 \\
20\end{array}$ & $\begin{array}{l}100 \\
150 \\
100 \\
150 \\
150\end{array}$ & $\begin{array}{l}15 \\
15 \\
15 \\
15 \\
15\end{array}$ & $\begin{array}{r}100 \\
70 \\
70 \\
100 \\
70\end{array}$ & $\begin{array}{l}\mathbf{N} \\
\mathbf{N} \\
\mathbf{N} \\
\mathbf{N} \\
7\end{array}$ & $\begin{array}{r}20 \\
\mathrm{~L} \\
\mathrm{~L} \\
\mathrm{~L} \\
\mathrm{~L}\end{array}$ \\
\hline $\begin{array}{l}610 \\
621 \\
623 \\
627 \\
628\end{array}$ & $\begin{array}{l}3 \\
1.5 \\
3 \\
3 \\
3\end{array}$ & $\begin{array}{r}1.5 \\
.5 \\
.7 \\
.7 \\
1\end{array}$ & $\begin{array}{l}1.5 \\
1.5 \\
1.5 \\
1.5 \\
1.5\end{array}$ & $\begin{array}{l}.7 \\
.3 \\
.5 \\
.3 \\
.5\end{array}$ & $\begin{array}{l}700 \\
300 \\
700 \\
700 \\
300\end{array}$ & $\begin{array}{l}N \\
N \\
N \\
L \\
N\end{array}$ & $\begin{array}{l}300 \\
300 \\
300 \\
300 \\
300\end{array}$ & $\begin{array}{l}1.5 \\
1 \\
1.5 \\
1.5\end{array}$ & $\begin{array}{r}20 \\
5 \\
20 \\
15 \\
15\end{array}$ & $\begin{array}{r}300 \\
20 \\
150 \\
150 \\
200\end{array}$ & $\begin{array}{l}15 \\
10 \\
15 \\
15 \\
15\end{array}$ & $\begin{array}{r}700 \\
20 \\
200 \\
100 \\
150\end{array}$ & $\begin{array}{l}\mathbf{N} \\
\mathbf{N} \\
\mathbf{N} \\
\mathbf{N} \\
\mathbf{N}\end{array}$ & $\begin{array}{c}L \\
L \\
10 \\
L \\
L\end{array}$ \\
\hline $\begin{array}{l}629 \\
630 \\
632 \\
636 \\
637\end{array}$ & $\begin{array}{l}3 \\
2 \\
3 \\
3 \\
3\end{array}$ & $\begin{array}{r}1.5 \\
.5 \\
.7 \\
1.5 \\
1.5\end{array}$ & $\begin{array}{l}2 \\
1 \\
1 \\
1.5 \\
1.5\end{array}$ & $\begin{array}{l}.3 \\
.3 \\
.3 \\
.5 \\
.5\end{array}$ & $\begin{array}{r}700 \\
700 \\
1,500 \\
500 \\
700\end{array}$ & $\begin{array}{l}N \\
L \\
N \\
L \\
L\end{array}$ & $\begin{array}{l}300 \\
200 \\
300 \\
300 \\
200\end{array}$ & $\begin{array}{l}1.5 \\
1.5 \\
1 \\
1 \\
1.5\end{array}$ & $\begin{array}{l}20 \\
15 \\
20 \\
20 \\
20\end{array}$ & $\begin{array}{r}150 \\
50 \\
150 \\
200 \\
300\end{array}$ & $\begin{array}{l}15 \\
20 \\
15 \\
20 \\
30\end{array}$ & $\begin{array}{r}50 \\
100 \\
150 \\
100 \\
30\end{array}$ & $\begin{array}{c}N \\
N \\
N \\
N \\
10\end{array}$ & $\begin{array}{r}L \\
10 \\
L \\
10 \\
10\end{array}$ \\
\hline $\begin{array}{l}642 \\
643 \\
645 \\
646 \\
647\end{array}$ & $\begin{array}{l}3 \\
3 \\
3 \\
3 \\
3\end{array}$ & $\begin{array}{l}3 \\
.7 \\
.7 \\
1.5\end{array}$ & $\begin{array}{l}1.5 \\
1.5 \\
1.5 \\
1.5 \\
1.5\end{array}$ & $\begin{array}{l}.5 \\
.2 \\
.5 \\
.3 \\
.2\end{array}$ & $\begin{array}{l}700 \\
700 \\
700 \\
700 \\
300\end{array}$ & $\begin{array}{c}N \\
N \\
N \\
N \\
10\end{array}$ & $\begin{array}{l}300 \\
200 \\
300 \\
300 \\
300\end{array}$ & $\begin{array}{l}1 \\
1 \\
1 \\
1 \\
1.5\end{array}$ & $\begin{array}{l}30 \\
10 \\
15 \\
15 \\
15\end{array}$ & $\begin{array}{r}700 \\
70 \\
100 \\
150 \\
150\end{array}$ & $\begin{array}{l}20 \\
10 \\
15 \\
15 \\
15\end{array}$ & $\begin{array}{r}50 \\
300 \\
700 \\
300 \\
70\end{array}$ & $\begin{array}{l}\mathbf{N} \\
\mathbf{N} \\
\mathbf{N} \\
\mathbf{N} \\
\mathbf{N}\end{array}$ & $\begin{array}{l}L \\
L \\
L \\
L \\
L\end{array}$ \\
\hline
\end{tabular}


Semiquantitative spectrographic analyses--Cont inued

\begin{tabular}{|c|c|c|c|c|c|c|c|c|c|}
\hline \multirow[b]{2}{*}{ Sample } & \multicolumn{6}{|c|}{$(\mathrm{ppm})$} & \multirow{2}{*}{$\frac{(\mathrm{ppm})}{\mathrm{C} \times \mathrm{HM}}$} & \multirow[b]{2}{*}{$\begin{array}{l}\text { Locat ion } \\
\text { Sec-Twp-Rge }\end{array}$} & \multirow[b]{2}{*}{ Drainage basin } \\
\hline & $\begin{array}{c}\mathrm{Pb} \\
(10)\end{array}$ & $\begin{array}{l}5 c \\
(5)\end{array}$ & $\begin{array}{c}5 r \\
(100)\end{array}$ & $\begin{array}{c}V \\
(10)\end{array}$ & $\begin{array}{c}\gamma \\
(10)\end{array}$ & $\begin{array}{c}2 r \\
(10)\end{array}$ & & & \\
\hline
\end{tabular}

Sand samples $\cdots$ Conti nued

\begin{tabular}{|c|c|c|c|c|c|c|c|c|c|}
\hline $\begin{array}{l}329 \\
330 \\
331 \\
333 \\
337\end{array}$ & $\begin{array}{l}20 \\
15 \\
15 \\
15 \\
20\end{array}$ & $\begin{array}{r}7 \\
15 \\
7 \\
7 \\
10\end{array}$ & $\begin{array}{r}N \\
100 \\
150 \\
150 \\
L\end{array}$ & $\begin{array}{l}30 \\
70 \\
30 \\
30 \\
30\end{array}$ & $\begin{array}{l}20 \\
70 \\
20 \\
30 \\
15\end{array}$ & $\begin{array}{l}150 \\
700 \\
150 \\
200 \\
150\end{array}$ & $\begin{array}{l}5 \\
1 \\
1 \\
1 \\
1\end{array}$ & $\begin{array}{l}32-38-106 \\
28-38-106 \\
28-38-106 \\
22-38-106 \\
31-39-105\end{array}$ & $\begin{array}{c}\text { Dinwoody } \mathrm{Cr} \text {. } \\
\text { Do. } \\
\text { Do. } \\
\text { Do. } \\
\text { Do. }\end{array}$ \\
\hline $\begin{array}{l}339 \\
342 \\
343 \\
346 \\
347\end{array}$ & $\begin{array}{l}30 \\
30 \\
50 \\
30 \\
50\end{array}$ & $\begin{array}{r}10 \\
10 \\
7 \\
7 \\
5\end{array}$ & $\begin{array}{r}150 \\
100 \\
150 \\
L \\
100\end{array}$ & $\begin{array}{l}50 \\
30 \\
50 \\
30 \\
20\end{array}$ & $\begin{array}{l}20 \\
30 \\
50 \\
20 \\
20\end{array}$ & $\begin{array}{l}100 \\
300 \\
150 \\
150 \\
100\end{array}$ & $\begin{array}{l}1 \\
8 \\
1 \\
1 \\
1\end{array}$ & $\begin{array}{l}28-39-106 \\
33-39-106 \\
33-38-106 \\
19-39-106 \\
19-39-106\end{array}$ & $\begin{array}{c}\text { Do. } \\
\text { Do. } \\
\text { Do. } \\
\text { Torrey } \mathrm{Cr} \text {. } \\
\text { Do. }\end{array}$ \\
\hline $\begin{array}{l}348 \\
349 \\
350 \\
351 \\
353\end{array}$ & $\begin{array}{l}30 \\
30 \\
30 \\
30 \\
30\end{array}$ & $\begin{array}{l}7 \\
7 \\
7 \\
7 \\
5\end{array}$ & $\begin{array}{r}\text { L } \\
\text { L } \\
100 \\
L \\
L\end{array}$ & $\begin{array}{l}30 \\
30 \\
50 \\
50 \\
20\end{array}$ & $\begin{array}{l}20 \\
20 \\
20 \\
20 \\
15\end{array}$ & $\begin{array}{l}100 \\
150 \\
150 \\
150 \\
150\end{array}$ & $\begin{array}{r}1 \\
1 \\
-3 \\
3 \\
3\end{array}$ & $\begin{array}{r}17-39-106 \\
8-39-106 \\
5-39-106 \\
32-40-106 \\
36-40-106\end{array}$ & $\begin{array}{l}\text { Do. } \\
\text { Do. } \\
\text { Do. } \\
\text { Do. } \\
\text { Do. }\end{array}$ \\
\hline $\begin{array}{l}356 \\
357 \\
358 \\
359 \\
360\end{array}$ & $\begin{array}{l}20 \\
15 \\
70 \\
50 \\
15\end{array}$ & $\begin{array}{r}10 \\
5 \\
10 \\
7 \\
5\end{array}$ & $\begin{array}{r}100 \\
L \\
150 \\
150 \\
L\end{array}$ & $\begin{array}{l}50 \\
30 \\
50 \\
50 \\
20\end{array}$ & $\begin{array}{l}50 \\
20 \\
30 \\
20 \\
10\end{array}$ & $\begin{array}{r}150 \\
150 \\
150 \\
150 \\
70\end{array}$ & $\begin{array}{l}1 \\
1 \\
1 \\
1 \\
1\end{array}$ & $\begin{array}{l}28-40-106 \\
21-40-106 \\
26-40-107 \\
23-40-107 \\
14-40-107\end{array}$ & $\begin{array}{l}\text { Do. } \\
\text { Do. } \\
\text { Jakeys Fork. } \\
\text { Do. } \\
\text { Do. }\end{array}$ \\
\hline $\begin{array}{l}361 \\
362 \\
365 \\
366 \\
367\end{array}$ & $\begin{array}{l}15 \\
20 \\
10 \\
30 \\
20\end{array}$ & $\begin{array}{l}5 \\
5 \\
7 \\
7 \\
7\end{array}$ & $\begin{array}{r}\text { L } \\
\text { N } \\
100 \\
L \\
L\end{array}$ & $\begin{array}{l}30 \\
30 \\
50 \\
70 \\
30\end{array}$ & $\begin{array}{l}15 \\
15 \\
15 \\
70 \\
20\end{array}$ & $\begin{array}{l}150 \\
150 \\
150 \\
500 \\
150\end{array}$ & $\begin{array}{l}1 \\
1 \\
1 \\
1 \\
1\end{array}$ & $\begin{array}{r}11-40-107 \\
2-40-107 \\
9-40-107 \\
21-40-106 \\
29-40-106\end{array}$ & $\begin{array}{c}\text { Do. } \\
\text { Do. } \\
\text { Do. } \\
\text { Torrey Cr. } \\
\text { Do. }\end{array}$ \\
\hline $\begin{array}{l}368 \\
369 \\
370 \\
372 \\
376\end{array}$ & $\begin{array}{l}20 \\
30 \\
15 \\
10 \\
10\end{array}$ & $\begin{array}{l}7 \\
7 \\
5 \\
7 \\
7\end{array}$ & $\begin{array}{r}150 \\
L \\
150 \\
100 \\
L\end{array}$ & $\begin{array}{l}30 \\
30 \\
20 \\
30 \\
50\end{array}$ & $\begin{array}{l}30 \\
15 \\
30 \\
30 \\
20\end{array}$ & $\begin{array}{l}100 \\
100 \\
300 \\
150 \\
200\end{array}$ & $\begin{array}{l}1 \\
1 \\
1 \\
1 \\
1\end{array}$ & $\begin{array}{r}26-40-107 \\
15-38-107 \\
1-37-107 \\
7-38-106 \\
11-38-106\end{array}$ & $\begin{array}{c}\text { Tourist Cr. } \\
\text { Dinwoody Cr. } \\
\text { Do. } \\
\text { Do. } \\
\text { Do. }\end{array}$ \\
\hline $\begin{array}{l}377 \\
378 \\
379 \\
383 \\
385\end{array}$ & $\begin{array}{l}20 \\
15 \\
30 \\
20 \\
15\end{array}$ & $\begin{array}{r}10 \\
15 \\
7 \\
10 \\
L\end{array}$ & $\begin{array}{r}L \\
100 \\
150 \\
L \\
150\end{array}$ & $\begin{array}{l}70 \\
50 \\
50 \\
70 \\
15\end{array}$ & $\begin{array}{l}30 \\
30 \\
20 \\
70 \\
10\end{array}$ & $\begin{array}{r}300 \\
200 \\
100 \\
200 \\
50\end{array}$ & $\begin{array}{l}1 \\
1 \\
1 \\
1 \\
1\end{array}$ & $\begin{array}{r}2-38-106 \\
2-38-106 \\
23-39-107 \\
27-39-106 \\
26-39-106\end{array}$ & $\begin{array}{c}\text { Do. } \\
\text { Do. } \\
\text { Torrey } \mathrm{Cr} \text {. } \\
\text { Dinwoody } \mathrm{Cr} \text {. } \\
\text { Do. }\end{array}$ \\
\hline $\begin{array}{l}387 \\
389 \\
391 \\
392 \\
394\end{array}$ & $\begin{array}{l}10 \\
10 \\
15 \\
20 \\
20\end{array}$ & $\begin{array}{r}7 \\
5 \\
10 \\
7 \\
10\end{array}$ & $\begin{array}{r}150 \\
100 \\
\mathrm{~L} \\
100 \\
150\end{array}$ & $\begin{array}{l}15 \\
15 \\
20 \\
30 \\
50\end{array}$ & $\begin{array}{l}20 \\
15 \\
20 \\
20 \\
70\end{array}$ & $\begin{array}{r}200 \\
30 \\
700 \\
200 \\
200\end{array}$ & $\begin{array}{l}1 \\
1 \\
1 \\
1 \\
1\end{array}$ & $\begin{array}{l}26-39-106 \\
24-39-106 \\
29-39-105 \\
10-4-6 \\
33-41-107\end{array}$ & $\begin{array}{c}\text { Do. } \\
\text { Do. } \\
\text { Do. } \\
\text { Do. } \\
\text { Jakeys Fork. }\end{array}$ \\
\hline $\begin{array}{l}396 \\
399 \\
400 \\
605 \\
609\end{array}$ & $\begin{array}{l}30 \\
30 \\
50 \\
20 \\
15\end{array}$ & $\begin{array}{l}15 \\
15 \\
15 \\
15 \\
15\end{array}$ & $\begin{array}{r}100 \\
200 \\
150 \\
1 \\
100\end{array}$ & $\begin{array}{r}100 \\
70 \\
70 \\
70 \\
100\end{array}$ & $\begin{array}{r}70 \\
70 \\
50 \\
150 \\
30\end{array}$ & $\begin{array}{l}300 \\
300 \\
300 \\
500 \\
200\end{array}$ & $\begin{array}{r}1 \\
3 \\
10 \\
3 \\
3\end{array}$ & $\begin{array}{r}3-39-107 \\
34-40-107 \\
35-40-107 \\
25-41-107 \\
36-41-108\end{array}$ & $\begin{array}{c}\text { Torrey Cr. } \\
\text { Do. } \\
\text { Do. } \\
\text { Jakeys Fork. } \\
\text { Do. }\end{array}$ \\
\hline $\begin{array}{l}610 \\
621 \\
623 \\
627 \\
628\end{array}$ & $\begin{array}{l}30 \\
10 \\
30 \\
15 \\
15\end{array}$ & $\begin{array}{r}20 \\
7 \\
15 \\
15 \\
15\end{array}$ & $\begin{array}{l}150 \\
200 \\
200 \\
100 \\
300\end{array}$ & $\begin{array}{r}100 \\
50 \\
70 \\
70 \\
70\end{array}$ & $\begin{array}{r}150 \\
15 \\
30 \\
20 \\
20\end{array}$ & $\begin{array}{r}1,000 \\
300 \\
300 \\
200 \\
300\end{array}$ & $\begin{array}{l}3 \\
5 \\
3 \\
5 \\
3\end{array}$ & $\begin{array}{l}35-41-108 \\
28-41-108 \\
29-41-108 \\
29-41-108 \\
30-41-108\end{array}$ & $\begin{array}{c}\text { Warm Spg Cr. } \\
\text { Do. } \\
\text { Do. } \\
\text { Do. } \\
\text { Do. }\end{array}$ \\
\hline $\begin{array}{l}629 \\
630 \\
632 \\
636 \\
637\end{array}$ & $\begin{array}{l}15 \\
30 \\
30 \\
20 \\
20\end{array}$ & $\begin{array}{l}20 \\
10 \\
15 \\
15 \\
15\end{array}$ & $\begin{array}{r}200 \\
100 \\
L \\
100 \\
100\end{array}$ & $\begin{array}{l}70 \\
50 \\
70 \\
70 \\
70\end{array}$ & $\begin{array}{r}200 \\
70 \\
50 \\
150 \\
30\end{array}$ & $\begin{array}{r}300 \\
1,000 \\
300 \\
200 \\
500\end{array}$ & $\begin{array}{r}3 \\
13 \\
13 \\
5 \\
3\end{array}$ & $\begin{array}{r}24-40-108 \\
30-40-107 \\
24-40-108 \\
13-40-108 \\
7-40-107\end{array}$ & $\begin{array}{c}\text { Jakeys Fork. } \\
\text { Do. } \\
\text { Do. } \\
\text { Do. } \\
\text { Do. }\end{array}$ \\
\hline $\begin{array}{l}642 \\
643 \\
645 \\
646 \\
647\end{array}$ & $\begin{array}{l}20 \\
15 \\
50 \\
30 \\
20\end{array}$ & $\begin{array}{l}20 \\
10 \\
15 \\
15 \\
15\end{array}$ & $\begin{array}{l}100 \\
100 \\
150 \\
100 \\
100\end{array}$ & $\begin{array}{r}100 \\
50 \\
70 \\
70 \\
70\end{array}$ & $\begin{array}{l}30 \\
20 \\
30 \\
30 \\
30\end{array}$ & $\begin{array}{l}300 \\
300 \\
300 \\
500 \\
300\end{array}$ & $\begin{array}{r}3 \\
13 \\
8 \\
10 \\
3\end{array}$ & $\begin{array}{r}6-40-107 \\
26-41-108 \\
23-41-108 \\
24-41-108 \\
24-41-108\end{array}$ & $\begin{array}{l}\text { Do. } \\
\text { Little Warm Spg Cr. } \\
\text { Do. } \\
\text { Do. } \\
\text { Do. }\end{array}$ \\
\hline
\end{tabular}


Semiquantitative spectrographic analyses

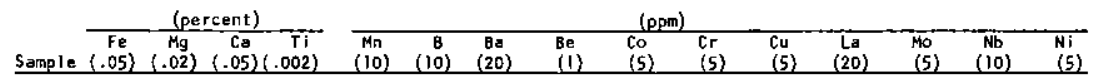

\section{Sand samples--Cont inued}

\begin{tabular}{|c|c|c|c|c|c|c|c|c|c|c|c|c|c|c|c|}
\hline $\begin{array}{l}648 \\
649 \\
650 \\
651 \\
653\end{array}$ & $\begin{array}{l}3 \\
3 \\
3 \\
3 \\
3\end{array}$ & $\begin{array}{l}1 \\
1 \\
1 \\
1.5 \\
1\end{array}$ & $\begin{array}{l}1 \\
1.5 \\
1.5 \\
1 \\
1.5\end{array}$ & $\begin{array}{r}0.3 \\
.3 \\
.2 \\
.3 \\
.3\end{array}$ & $\begin{array}{l}300 \\
500 \\
700 \\
300 \\
500\end{array}$ & $\begin{array}{r}\mathrm{L} \\
10 \\
\mathrm{~N} \\
10 \\
\mathrm{~N}\end{array}$ & $\begin{array}{l}300 \\
300 \\
300 \\
500 \\
300\end{array}$ & $\begin{array}{l}1.5 \\
1 \\
1 \\
1 \\
1\end{array}$ & $\begin{array}{l}15 \\
20 \\
15 \\
15 \\
15\end{array}$ & $\begin{array}{r}150 \\
300 \\
150 \\
200 \\
70\end{array}$ & $\begin{array}{l}15 \\
20 \\
20 \\
20 \\
15\end{array}$ & $\begin{array}{r}70 \\
150 \\
50 \\
100 \\
70\end{array}$ & $\begin{array}{l}\mathbf{N} \\
\mathrm{N} \\
\mathrm{N} \\
\mathrm{L} \\
\mathrm{N}\end{array}$ & $\begin{array}{l}L \\
L \\
L \\
L \\
L\end{array}$ & $\begin{array}{l}70 \\
50 \\
70 \\
70 \\
20\end{array}$ \\
\hline $\begin{array}{l}654 \\
665 \\
666 \\
673 \\
674\end{array}$ & $\begin{array}{l}2 \\
3 \\
3 \\
3 \\
3\end{array}$ & $\begin{array}{r}.7 \\
.7 \\
1.5 \\
.7 \\
1.5\end{array}$ & $\begin{array}{l}.5 \\
.7 \\
1.5 \\
1.5 \\
1.5\end{array}$ & $\begin{array}{r}.3 \\
.2 \\
3 \\
.5 \\
.3\end{array}$ & $\begin{array}{l}200 \\
200 \\
700 \\
500 \\
700\end{array}$ & $\begin{array}{l}30 \\
N \\
L \\
N \\
N\end{array}$ & $\begin{array}{l}500 \\
100 \\
200 \\
300 \\
300\end{array}$ & $\begin{array}{l}1 \\
1 \\
1 \\
1 \\
1.5\end{array}$ & $\begin{array}{l}15 \\
10 \\
15 \\
15 \\
20\end{array}$ & $\begin{array}{r}70 \\
15 \\
150 \\
100 \\
200\end{array}$ & $\begin{array}{l}7 \\
15 \\
15 \\
10 \\
15\end{array}$ & $\begin{array}{r}30 \\
70 \\
50 \\
50 \\
100\end{array}$ & $\begin{array}{l}N \\
N \\
N \\
N \\
N\end{array}$ & $\begin{array}{l}\mathbf{L} \\
\mathbf{L} \\
\mathbf{L} \\
\mathbf{L} \\
\mathbf{L}\end{array}$ & $\begin{array}{l}20 \\
15 \\
70 \\
30 \\
70\end{array}$ \\
\hline $\begin{array}{l}675 \\
677 \\
678 \\
679 \\
681\end{array}$ & $\begin{array}{l}3 \\
3 \\
7 \\
3 \\
2\end{array}$ & $\begin{array}{r}1.5 \\
1.5 \\
.7 \\
1.5 \\
.7\end{array}$ & $\begin{array}{l}1.5 \\
1.5 \\
1 \\
1.5 \\
.7\end{array}$ & $\begin{array}{l}.3 \\
.3 \\
.3 \\
.3 \\
.3\end{array}$ & $\begin{array}{l}700 \\
500 \\
300 \\
700 \\
150\end{array}$ & $\begin{array}{r}\mathrm{L} \\
\mathrm{N} \\
10 \\
10 \\
\mathrm{~L}\end{array}$ & $\begin{array}{l}300 \\
300 \\
300 \\
300 \\
700\end{array}$ & $\begin{array}{l}1 \\
2 \\
1.5 \\
2 \\
1.5\end{array}$ & $\begin{array}{l}20 \\
15 \\
15 \\
15 \\
10\end{array}$ & $\begin{array}{r}200 \\
150 \\
100 \\
150 \\
70\end{array}$ & $\begin{array}{l}15 \\
10 \\
15 \\
15 \\
10\end{array}$ & $\begin{array}{r}200 \\
30 \\
30 \\
150 \\
70\end{array}$ & $\begin{array}{l}\mathbf{N} \\
\mathbf{N} \\
\mathbf{N} \\
\mathbf{N} \\
\mathbf{N}\end{array}$ & $\begin{array}{l}\mathbf{L} \\
\mathbf{L} \\
\mathbf{L} \\
\mathbf{L}\end{array}$ & 20 \\
\hline $\begin{array}{l}682 \\
684 \\
706 \\
707 \\
711\end{array}$ & $\begin{array}{l}3 \\
3 \\
5 \\
7 \\
3\end{array}$ & $\begin{array}{l}1 \\
1 \\
.7 \\
.7 \\
.7\end{array}$ & $\begin{array}{l}1 \\
1 \\
.7 \\
.7 \\
.7\end{array}$ & $\begin{array}{l}.3 \\
.3 \\
.5 \\
.5 \\
.3\end{array}$ & $\begin{array}{l}300 \\
300 \\
700 \\
700 \\
700\end{array}$ & $\begin{array}{r}30 \\
L \\
10 \\
L \\
L\end{array}$ & $\begin{array}{l}300 \\
500 \\
300 \\
300 \\
500\end{array}$ & $\begin{array}{l}1.5 \\
1 \\
1 \\
1\end{array}$ & $\begin{array}{l}15 \\
15 \\
20 \\
20 \\
15\end{array}$ & $\begin{array}{r}70 \\
150 \\
150 \\
150 \\
150\end{array}$ & $\begin{array}{l}15 \\
15 \\
15 \\
15 \\
15\end{array}$ & $\begin{array}{r}70 \\
70 \\
70 \\
70 \\
100\end{array}$ & $\begin{array}{l}\mathbf{N} \\
\mathbf{N} \\
\mathbf{N} \\
\mathbf{N} \\
\mathbf{N}\end{array}$ & $\begin{array}{l}\text { L } \\
\text { L } \\
\text { L } \\
\text { L } \\
\text { L }\end{array}$ & $\begin{array}{l}30 \\
50 \\
70 \\
50 \\
70\end{array}$ \\
\hline $\begin{array}{l}712 \\
713 \\
716 \\
717 \\
719\end{array}$ & $\begin{array}{l}5 \\
5 \\
5 \\
5 \\
5\end{array}$ & $\begin{array}{l}.7 \\
1.5 \\
1.5 \\
1.5 \\
1\end{array}$ & $\begin{array}{l}.7 \\
.7 \\
.7 \\
.7 \\
.7\end{array}$ & $\begin{array}{l}.3 \\
.3 \\
.3 \\
.5 \\
.3\end{array}$ & $\begin{array}{r}1,500 \\
300 \\
500 \\
500 \\
500\end{array}$ & $\begin{array}{r}10 \\
\mathrm{~L} \\
\mathrm{~L} \\
\mathrm{~N} \\
\mathrm{~N}\end{array}$ & $\begin{array}{l}500 \\
200 \\
300 \\
300 \\
300\end{array}$ & $\begin{array}{l}1 \\
1.5 \\
1 \\
1 \\
1\end{array}$ & $\begin{array}{l}50 \\
70 \\
30 \\
30 \\
30\end{array}$ & $\begin{array}{l}200 \\
200 \\
300 \\
300 \\
200\end{array}$ & $\begin{array}{r}15 \\
15 \\
7 \\
7 \\
10\end{array}$ & $\begin{array}{r}100 \\
100 \\
70 \\
200 \\
70\end{array}$ & $\begin{array}{l}\mathbf{N} \\
\mathbf{N} \\
\mathbf{N} \\
\mathbf{N} \\
\mathbf{N}\end{array}$ & $\begin{array}{l}\mathrm{L} \\
\mathrm{L} \\
\mathrm{N} \\
\mathrm{N} \\
\mathrm{L}\end{array}$ & $\begin{array}{r}100 \\
70 \\
100 \\
100 \\
100\end{array}$ \\
\hline $\begin{array}{l}720 \\
724 \\
732 \\
733 \\
734\end{array}$ & $\begin{array}{l}3 \\
7 \\
1.5 \\
3 \\
2\end{array}$ & $\begin{array}{l}1 \\
.7 \\
.1 \\
.5 \\
.3\end{array}$ & $\begin{array}{l}.7 \\
.3 \\
.7 \\
.3\end{array}$ & $\begin{array}{l}.3 \\
.5 \\
.2 \\
.2 \\
.2\end{array}$ & $\begin{array}{l}300 \\
500 \\
300 \\
100 \\
200\end{array}$ & $\begin{array}{l}\mathrm{L} \\
\mathrm{L} \\
10 \\
10 \\
15\end{array}$ & $\begin{array}{l}300 \\
300 \\
300 \\
300 \\
700\end{array}$ & $\begin{array}{l}\text { I } \\
\text { I } \\
\text { L } \\
\text { L } \\
\text { i }\end{array}$ & $\begin{array}{r}20 \\
20 \\
7 \\
15 \\
15\end{array}$ & $\begin{array}{r}150 \\
150 \\
30 \\
70 \\
30\end{array}$ & $\begin{array}{r}10 \\
30 \\
7 \\
10 \\
7\end{array}$ & $\begin{array}{l}50 \\
50 \\
30 \\
30 \\
50\end{array}$ & $\begin{array}{l}\mathbf{N} \\
\mathbf{N} \\
\mathbf{N} \\
\mathbf{N} \\
\mathbf{N}\end{array}$ & $\begin{array}{l}\text { N } \\
\text { L } \\
\text { L } \\
\text { N } \\
\text { L }\end{array}$ & $\begin{array}{r}100 \\
30 \\
20 \\
50 \\
30\end{array}$ \\
\hline $\begin{array}{l}735 \\
737 \\
741 \\
758 \\
764\end{array}$ & $\begin{array}{l}5 \\
3 \\
3 \\
3 \\
1.5\end{array}$ & $\begin{array}{r}2 \\
1.5 \\
1.5 \\
.7 \\
.1\end{array}$ & $\begin{array}{c}2 \\
.5 \\
1.5 \\
.7 \\
.07\end{array}$ & $\begin{array}{l}.3 \\
.3 \\
.2 \\
.3 \\
.2\end{array}$ & $\begin{array}{l}500 \\
500 \\
500 \\
500 \\
150\end{array}$ & $\begin{array}{r}N \\
10 \\
N \\
2 \\
15\end{array}$ & $\begin{array}{l}200 \\
300 \\
300 \\
200 \\
500\end{array}$ & $\begin{array}{l}1 \\
1 \\
1 \\
1.5 \\
1.5\end{array}$ & $\begin{array}{l}50 \\
30 \\
15 \\
15 \\
10\end{array}$ & $\begin{array}{l}700 \\
200 \\
200 \\
150 \\
200\end{array}$ & $\begin{array}{r}7 \\
30 \\
7 \\
10 \\
L\end{array}$ & $\begin{array}{r}30 \\
150 \\
20 \\
50 \\
30\end{array}$ & $\begin{array}{l}\mathbf{N} \\
\mathbf{N} \\
\mathbf{N} \\
\mathbf{N} \\
\mathbf{N}\end{array}$ & $\begin{array}{l}\mathbf{L} \\
\mathbf{L} \\
\mathbf{L} \\
\mathbf{L} \\
\mathbf{L}\end{array}$ & $\begin{array}{r}200 \\
150 \\
70 \\
70\end{array}$ \\
\hline $\begin{array}{l}765 \\
769 \\
770 \\
773 \\
779\end{array}$ & $\begin{array}{l}3 \\
7 \\
5 \\
5 \\
7\end{array}$ & $\begin{array}{l}3^{.2} \\
2 \\
1.5\end{array}$ & $\begin{array}{l}2^{-7} \\
2 \\
1 \\
2\end{array}$ & $\begin{array}{l}.3 \\
.3 \\
.5 \\
.2 \\
.5\end{array}$ & $\begin{array}{r}300 \\
\mathrm{t}, 000 \\
700 \\
700 \\
700\end{array}$ & $\begin{array}{r}15 \\
N \\
N \\
N \\
N\end{array}$ & $\begin{array}{l}700 \\
300 \\
200 \\
500 \\
300\end{array}$ & $\begin{array}{l}1.5 \\
L \\
L \\
L \\
L\end{array}$ & $\begin{array}{l}10 \\
20 \\
15 \\
15 \\
15\end{array}$ & $\begin{array}{r}20 \\
500 \\
300 \\
300 \\
300\end{array}$ & $\begin{array}{l}15 \\
10 \\
10 \\
15 \\
15\end{array}$ & $\begin{array}{r}20 \\
30 \\
50 \\
30 \\
100\end{array}$ & $\begin{array}{l}N \\
N \\
N \\
N \\
N\end{array}$ & $\begin{array}{c}\mathrm{L} \\
\mathrm{L} \\
\mathrm{L} \\
\mathrm{L} \\
10\end{array}$ & $\begin{array}{l}10 \\
70 \\
70 \\
50 \\
70\end{array}$ \\
\hline $\begin{array}{l}782 \\
783 \\
785 \\
787 \\
788\end{array}$ & $\begin{array}{l}3 \\
3 \\
2 \\
7 \\
7\end{array}$ & $\begin{array}{l}1 \\
1 \\
i\end{array}$ & $\begin{array}{l}1 \\
1 \\
1 \\
2 \\
1.5\end{array}$ & $\begin{array}{l}.2 \\
.3 \\
.3 \\
.3 \\
.3\end{array}$ & $\begin{array}{l}300 \\
300 \\
200 \\
300 \\
300\end{array}$ & $\begin{array}{l}\mathbf{N} \\
\mathbf{N} \\
\mathbf{N} \\
\mathbf{N} \\
\mathbf{N}\end{array}$ & $\begin{array}{l}300 \\
300 \\
300 \\
300 \\
300\end{array}$ & $\begin{array}{l}\mathrm{L} \\
\mathrm{l} \\
\mathrm{L} \\
\mathrm{L} \\
\mathrm{L}\end{array}$ & $\begin{array}{r}10 \\
10 \\
5 \\
15 \\
15\end{array}$ & $\begin{array}{l}70 \\
70 \\
15 \\
70 \\
70\end{array}$ & $\begin{array}{r}5 \\
7 \\
1 \\
10 \\
10\end{array}$ & $\begin{array}{r}100 \\
70 \\
200 \\
50 \\
150\end{array}$ & $\begin{array}{l}\mathbf{N} \\
\mathbf{N} \\
\mathbf{N} \\
\mathbf{N} \\
\mathbf{N}\end{array}$ & $\begin{array}{r}L \\
L \\
10 \\
10 \\
L\end{array}$ & $\begin{array}{l}30 \\
30 \\
10 \\
30 \\
30\end{array}$ \\
\hline $\begin{array}{l}790 \\
792 \\
793 \\
798 \\
904\end{array}$ & $\begin{array}{l}3 \\
2 \\
7 \\
3 \\
5\end{array}$ & $\begin{array}{r}1 \\
.7 \\
1.5 \\
.7 \\
1.5\end{array}$ & $\begin{array}{l}2 \\
1 \\
1.5 \\
1.5 \\
.7\end{array}$ & $\begin{array}{l}.3 \\
.1 \\
.3 \\
.1 \\
.3\end{array}$ & $\begin{array}{l}500 \\
300 \\
700 \\
700 \\
700\end{array}$ & $\begin{array}{l}\mathbf{N} \\
N \\
\mathbf{L} \\
\mathbf{N} \\
\mathbf{N}\end{array}$ & $\begin{array}{l}500 \\
300 \\
300 \\
300 \\
200\end{array}$ & $\begin{array}{l}\mathrm{L} \\
\mathrm{L} \\
\mathrm{L} \\
\mathrm{L} \\
\mathrm{l}\end{array}$ & $\begin{array}{l}5 \\
10 \\
15 \\
15 \\
50\end{array}$ & $\begin{array}{r}30 \\
20 \\
100 \\
100 \\
1,500\end{array}$ & $\begin{array}{r}7 \\
10 \\
20 \\
7 \\
20\end{array}$ & $\begin{array}{r}150 \\
20 \\
70 \\
20 \\
50\end{array}$ & $\begin{array}{l}\mathrm{N} \\
\mathrm{N} \\
\mathrm{N} \\
\mathrm{N} \\
\mathrm{N}\end{array}$ & $\begin{array}{l}\mathrm{L} \\
\mathbf{L} \\
\mathbf{L} \\
\mathrm{L} \\
\mathrm{L}\end{array}$ & $\begin{array}{r}20 \\
20 \\
50 \\
30 \\
200\end{array}$ \\
\hline $\begin{array}{l}922 \\
924 \\
925 \\
927 \\
929\end{array}$ & $\begin{array}{l}3 \\
3 \\
5 \\
3 \\
5\end{array}$ & $\begin{array}{l}1 \\
1.5 \\
2 \\
1.5 \\
1.5\end{array}$ & $\begin{array}{l}3^{.5} \\
1 \\
2 \\
1.5\end{array}$ & $\begin{array}{l}.3 \\
.3 \\
.3 \\
.3 \\
.2\end{array}$ & $\begin{array}{l}500 \\
700 \\
700 \\
500 \\
500\end{array}$ & $\begin{array}{l}\mathbf{N} \\
\mathbf{N} \\
\mathrm{L} \\
\mathrm{N} \\
\mathrm{N}\end{array}$ & $\begin{array}{l}300 \\
700 \\
300 \\
300 \\
300\end{array}$ & $\begin{array}{l}1 \\
1 \\
L \\
L \\
1\end{array}$ & $\begin{array}{r}15 \\
7 \\
15 \\
15 \\
15\end{array}$ & $\begin{array}{r}150 \\
100 \\
300 \\
70 \\
300\end{array}$ & $\begin{array}{r}15 \\
7 \\
20 \\
7 \\
15\end{array}$ & $\begin{array}{r}100 \\
30 \\
100 \\
150 \\
50\end{array}$ & $\begin{array}{l}\mathbf{N} \\
\mathbf{N} \\
\mathbf{N} \\
\mathbf{N} \\
\mathrm{N}\end{array}$ & $\begin{array}{r}\mathrm{L} \\
\mathrm{L} \\
\mathrm{L} \\
10 \\
\mathrm{~L}\end{array}$ & $\begin{array}{l}30 \\
30 \\
70 \\
30 \\
50\end{array}$ \\
\hline $\begin{array}{l}930 \\
931 \\
933 \\
935 \\
937\end{array}$ & $\begin{array}{l}2 \\
3 \\
3 \\
2 \\
3\end{array}$ & $\begin{array}{r}.7 \\
.7 \\
.7 \\
1.5 \\
1.5\end{array}$ & $\begin{array}{l}1.5 \\
1 \\
1.5 \\
1.5 \\
2\end{array}$ & $\begin{array}{l}.1 \\
.2 \\
.2 \\
.2 \\
.3\end{array}$ & $\begin{array}{l}200 \\
300 \\
300 \\
300 \\
300\end{array}$ & $\begin{array}{l}\mathbf{N} \\
\mathrm{N} \\
\mathrm{N} \\
\mathrm{N} \\
\mathrm{N}\end{array}$ & $\begin{array}{l}500 \\
300 \\
300 \\
300 \\
300\end{array}$ & $\begin{array}{l}\text { l } \\
L \\
L \\
L \\
N\end{array}$ & $\begin{array}{r}7 \\
10 \\
7 \\
10 \\
7\end{array}$ & $\begin{array}{r}20 \\
30 \\
30 \\
200 \\
150\end{array}$ & $\begin{array}{l}5 \\
5 \\
5 \\
5 \\
5\end{array}$ & $\begin{array}{l}30 \\
20 \\
30 \\
50 \\
20\end{array}$ & $\begin{array}{l}\mathbf{N} \\
\mathbf{N} \\
\mathbf{N} \\
\mathbf{N} \\
\mathbf{N}\end{array}$ & $\begin{array}{l}N \\
L \\
L \\
N \\
L\end{array}$ & $\begin{array}{l}15 \\
30 \\
20 \\
70 \\
30\end{array}$ \\
\hline
\end{tabular}


the Glacier Primitive Areat, Fremom Cothty-Continued

Semiquantitative spectrographic analyses--Cont inued

\begin{tabular}{|c|c|c|c|c|c|c|c|c|c|}
\hline Sample & $\begin{array}{c}\mathrm{Pb} \\
(10)\end{array}$ & $\begin{array}{l}5 c \\
\text { (5) }\end{array}$ & $\begin{array}{c}5 \bar{r} \\
(100)\end{array}$ & $\begin{array}{c}V \\
(10)\end{array}$ & $\begin{array}{c}Y \\
(10)\end{array}$ & $\begin{array}{l}\bar{z} r \\
(10)\end{array}$ & $\frac{(\mathrm{ppm})}{\mathrm{C} \times \mathrm{HM}}$ & $\begin{array}{l}\text { Location } \\
\text { Sec-Twp-Rge }\end{array}$ & Drainage basin \\
\hline
\end{tabular}

Sand samples--Cont inued

\begin{tabular}{|c|c|c|c|c|c|c|c|c|c|}
\hline $\begin{array}{l}648 \\
649 \\
650 \\
651 \\
653\end{array}$ & $\begin{array}{l}15 \\
30 \\
30 \\
30 \\
20\end{array}$ & $\begin{array}{l}15 \\
20 \\
15 \\
15 \\
15\end{array}$ & $\begin{array}{l}100 \\
150 \\
200 \\
150 \\
100\end{array}$ & $\begin{array}{l}70 \\
70 \\
70 \\
70 \\
70\end{array}$ & $\begin{array}{r}30 \\
50 \\
30 \\
100 \\
30\end{array}$ & $\begin{array}{l}700 \\
700 \\
500 \\
200 \\
300\end{array}$ & $\begin{array}{l}3 \\
3 \\
3 \\
1 \\
3\end{array}$ & $\begin{array}{r}19-41-107 \\
24-41-108 \\
24-4 i-108 \\
1-39-108 \\
30-40-107\end{array}$ & $\begin{array}{l}\text { Little Warm Spg Cr. } \\
\text { Do. } \\
\text { Do. } \\
\text { Jakeys Fork. } \\
\text { Do. }\end{array}$ \\
\hline $\begin{array}{l}654 \\
665 \\
666 \\
673 \\
674\end{array}$ & $\begin{array}{r}20 \\
L \\
20 \\
15 \\
15\end{array}$ & $\begin{array}{l}7 \\
7 \\
15 \\
10 \\
20\end{array}$ & $\begin{array}{l}100 \\
100 \\
150 \\
100 \\
150\end{array}$ & $\begin{array}{r}50 \\
30 \\
70 \\
70 \\
100\end{array}$ & $\begin{array}{l}20 \\
10 \\
20 \\
15 \\
30\end{array}$ & $\begin{array}{l}300 \\
150 \\
300 \\
500 \\
700\end{array}$ & $\begin{array}{l}3 \\
1 \\
1 \\
1 \\
1\end{array}$ & $\begin{array}{r}7-40-107 \\
30-40-107 \\
19-40-107 \\
31-41-108 \\
24-41-108\end{array}$ & $\begin{array}{l}\text { Do. } \\
\text { Do. } \\
\text { Do. } \\
\text { Warm Spg Cr. } \\
\text { Little Warm Spg Cr. }\end{array}$ \\
\hline $\begin{array}{l}675 \\
677 \\
678 \\
679 \\
681\end{array}$ & $\begin{array}{l}30 \\
15 \\
15 \\
15 \\
15\end{array}$ & $\begin{array}{l}15 \\
15 \\
15 \\
15 \\
10\end{array}$ & $\begin{array}{l}100 \\
100 \\
100 \\
100 \\
100\end{array}$ & $\begin{array}{r}100 \\
70 \\
70 \\
70 \\
30\end{array}$ & $\begin{array}{l}30 \\
20 \\
30 \\
30 \\
50\end{array}$ & $\begin{array}{l}300 \\
500 \\
700 \\
700 \\
700\end{array}$ & $\begin{array}{l}3 \\
5 \\
3 \\
5 \\
1\end{array}$ & $\begin{array}{r}19-41-107 \\
19-41-107 \\
19-41-107 \\
20-41-107 \\
16-41-107\end{array}$ & $\begin{array}{l}\text { Do. } \\
\text { Do. } \\
\text { Do. } \\
\text { Do. } \\
\text { Do. }\end{array}$ \\
\hline $\begin{array}{l}682 \\
684 \\
706 \\
707 \\
711\end{array}$ & $\begin{array}{r}15 \\
15 \\
15 \\
2 \\
20\end{array}$ & $\begin{array}{l}10 \\
10 \\
15 \\
15 \\
15\end{array}$ & $\begin{array}{r}100 \\
100 \\
L \\
100 \\
L\end{array}$ & $\begin{array}{l}50 \\
70 \\
70 \\
70 \\
70\end{array}$ & $\begin{array}{l}30 \\
20 \\
15 \\
20 \\
50\end{array}$ & $\begin{array}{l}300 \\
200 \\
700 \\
300 \\
500\end{array}$ & $\begin{array}{l}3 \\
8 \\
3 \\
1 \\
3\end{array}$ & $\begin{array}{l}16-41-107 \\
17-41-107 \\
23-41-108 \\
22-41-108 \\
33-41-107\end{array}$ & $\begin{array}{l}\text { Do. } \\
\text { Do. } \\
\text { Canyon Cr. } \\
\text { Warm Spg Cr. } \\
\text { Jakeys Fork. }\end{array}$ \\
\hline $\begin{array}{l}712 \\
713 \\
716 \\
717 \\
719\end{array}$ & $\begin{array}{r}50 \\
L \\
10 \\
L \\
L\end{array}$ & $\begin{array}{l}15 \\
15 \\
15 \\
15 \\
15\end{array}$ & $\begin{array}{r}100 \\
100 \\
100 \\
L \\
L\end{array}$ & $\begin{array}{l}70 \\
70 \\
70 \\
70 \\
70\end{array}$ & $\begin{array}{l}30 \\
30 \\
20 \\
70 \\
50\end{array}$ & $\begin{array}{l}100 \\
300 \\
300 \\
300 \\
500\end{array}$ & $\begin{array}{l}1 \\
1 \\
3 \\
1 \\
3\end{array}$ & $\begin{array}{r}33-41-107 \\
4-40-107 \\
34-41-107 \\
35-41-107 \\
35-41-107\end{array}$ & $\begin{array}{l}\text { Do. } \\
\text { Do. } \\
\text { Do. } \\
\text { Do. } \\
\text { Do. }\end{array}$ \\
\hline $\begin{array}{l}720 \\
724 \\
732 \\
733 \\
734\end{array}$ & $\begin{array}{r}N \\
15 \\
L \\
10 \\
10\end{array}$ & $\begin{array}{r}10 \\
15 \\
5 \\
7 \\
7\end{array}$ & $\begin{array}{r}\mathrm{L} \\
150 \\
\mathrm{~L} \\
\mathrm{~N} \\
100\end{array}$ & $\begin{array}{r}70 \\
100 \\
30 \\
30 \\
30\end{array}$ & $\begin{array}{l}15 \\
20 \\
10 \\
10 \\
15\end{array}$ & $\begin{array}{r}200 \\
\mathrm{I}, 000 \\
300 \\
200 \\
300\end{array}$ & $\begin{array}{l}3 \\
1 \\
1 \\
3 \\
3\end{array}$ & $\begin{array}{r}25-41-107 \\
16-41-108 \\
15-41-107 \\
10-41-107 \\
6-41-107\end{array}$ & $\begin{array}{l}\text { Do. } \\
\text { Wildcat Cr. } \\
\text { Little Warm Spg Cr. } \\
\text { Do. } \\
\text { Do. }\end{array}$ \\
\hline $\begin{array}{l}735 \\
737 \\
741 \\
758 \\
764\end{array}$ & $\begin{array}{l}10 \\
70 \\
30 \\
20 \\
15\end{array}$ & $\begin{array}{r}15 \\
10 \\
15 \\
15 \\
7\end{array}$ & $\begin{array}{r}200 \\
100 \\
200 \\
L \\
L\end{array}$ & $\begin{array}{l}70 \\
70 \\
70 \\
70 \\
30\end{array}$ & $\begin{array}{l}30 \\
20 \\
15 \\
20 \\
20\end{array}$ & $\begin{array}{r}100 \\
50 \\
100 \\
300 \\
700\end{array}$ & $\begin{array}{r}3 \\
15 \\
1 \\
10 \\
3\end{array}$ & $\begin{array}{r}10-37-106 \\
10-37-106 \\
2-37-106 \\
25-38-106 \\
27-41-107\end{array}$ & $\begin{array}{c}\text { Dry Cr. } \\
\text { Do. } \\
\text { Do. } \\
\text { Do. } \\
\text { Limekiln Gulch. }\end{array}$ \\
\hline $\begin{array}{l}765 \\
769 \\
770 \\
773 \\
779\end{array}$ & $\begin{array}{l}10 \\
15 \\
20 \\
20 \\
20\end{array}$ & $\begin{array}{l}7 \\
30 \\
15 \\
10 \\
20\end{array}$ & $\begin{array}{r}L \\
150 \\
100 \\
100 \\
100\end{array}$ & $\begin{array}{r}30 \\
150 \\
100 \\
70 \\
150\end{array}$ & $\begin{array}{l}15 \\
30 \\
30 \\
20 \\
50\end{array}$ & $\begin{array}{r}300 \\
200 \\
70 \\
150 \\
500\end{array}$ & $\begin{array}{l}1 \\
1 \\
1 \\
3 \\
1\end{array}$ & $\begin{array}{r}23-41-107 \\
4-36-106 \\
36-37-106 \\
31-37-105 \\
36-41-108\end{array}$ & $\begin{array}{l}\text { Do. } \\
\text { Bull Lake Cr. } \\
\text { Do. } \\
\text { Do. } \\
\text { Jakeys Fork. }\end{array}$ \\
\hline $\begin{array}{l}782 \\
783 \\
785 \\
787 \\
788\end{array}$ & $\begin{array}{l}20 \\
20 \\
15 \\
20 \\
30\end{array}$ & $\begin{array}{l}10 \\
10 \\
10 \\
15 \\
15\end{array}$ & $\begin{array}{l}L \\
100 \\
150 \\
200 \\
300\end{array}$ & $\begin{array}{l}50 \\
50 \\
50 \\
70 \\
70\end{array}$ & $\begin{array}{l}30 \\
30 \\
50 \\
30 \\
30\end{array}$ & $\begin{array}{l}150 \\
200 \\
100 \\
300 \\
300\end{array}$ & $\begin{array}{l}1 \\
1 \\
1 \\
3 \\
3\end{array}$ & $\begin{array}{r}24-39-107 \\
14-39-107 \\
11-38-106 \\
34-37-106 \\
1-36-107\end{array}$ & $\begin{array}{c}\text { Torrey } \mathrm{Cr} \text {. } \\
\text { Do. } \\
\text { Dinwoody } \mathrm{Cr} \text {. } \\
\text { Bull Lake } \mathrm{Cr} \text {. } \\
\text { Do. }\end{array}$ \\
\hline $\begin{array}{l}790 \\
792 \\
793 \\
798 \\
904\end{array}$ & $\begin{array}{l}20 \\
20 \\
70 \\
20 \\
15\end{array}$ & $\begin{array}{r}7 \\
7 \\
20 \\
10 \\
15\end{array}$ & $\begin{array}{r}150 \\
100 \\
100 \\
100 \\
\mathrm{~L}\end{array}$ & $\begin{array}{l}30 \\
30 \\
70 \\
70 \\
70\end{array}$ & $\begin{array}{l}30 \\
30 \\
30 \\
15 \\
20\end{array}$ & $\begin{array}{r}150 \\
70 \\
20 \\
150 \\
200\end{array}$ & $\begin{array}{l}3 \\
3 \\
1 \\
5 \\
3\end{array}$ & $\begin{array}{c}34-37-106 \\
34-37-106 \\
33-37-106 \\
34-38-6 \\
6-37-105\end{array}$ & $\begin{array}{l}\text { Do. } \\
\text { Do. } \\
\text { Do. } \\
\text { Bob Cr. } \\
\text { Dry } \mathrm{Cr} .\end{array}$ \\
\hline $\begin{array}{l}922 \\
924 \\
925 \\
927 \\
929\end{array}$ & $\begin{array}{l}10 \\
20 \\
50 \\
20 \\
30\end{array}$ & $\begin{array}{l}10 \\
15 \\
15 \\
15 \\
15\end{array}$ & $\begin{array}{r}5 \\
500 \\
100 \\
200 \\
L\end{array}$ & $\begin{array}{l}70 \\
70 \\
70 \\
70 \\
70\end{array}$ & $\begin{array}{l}30 \\
20 \\
20 \\
30 \\
30\end{array}$ & $\begin{array}{r}1,000 \\
100 \\
150 \\
70 \\
150\end{array}$ & $\begin{array}{l}5 \\
3 \\
3 \\
3 \\
1\end{array}$ & $\begin{array}{r}30-41-106 \\
5-36-106 \\
35-37-106 \\
35-37-106 \\
34-37-106\end{array}$ & $\begin{array}{l}\text { Jakeys Fork. } \\
\text { Bull Lake Cr. } \\
\text { Do. } \\
\text { Do. } \\
\text { Do. }\end{array}$ \\
\hline $\begin{array}{l}930 \\
931 \\
933 \\
935 \\
937\end{array}$ & $\begin{array}{l}15 \\
15 \\
15 \\
15 \\
15\end{array}$ & $\begin{array}{r}7 \\
7 \\
10 \\
7 \\
7\end{array}$ & $\begin{array}{r}150 \\
100 \\
100 \\
150 \\
L\end{array}$ & $\begin{array}{l}30 \\
50 \\
50 \\
30 \\
30\end{array}$ & $\begin{array}{l}10 \\
20 \\
15 \\
15 \\
30\end{array}$ & $\begin{array}{r}70 \\
150 \\
150 \\
100 \\
70\end{array}$ & $\begin{array}{l}1 \\
3 \\
1 \\
1 \\
5\end{array}$ & $\begin{array}{l}34-37-106 \\
27-37-106 \\
26-37-106 \\
25-37-106 \\
30-37-105\end{array}$ & $\begin{array}{l}\text { Do. } \\
\text { Do. } \\
\text { Do. } \\
\text { Do. } \\
\text { Do. }\end{array}$ \\
\hline
\end{tabular}




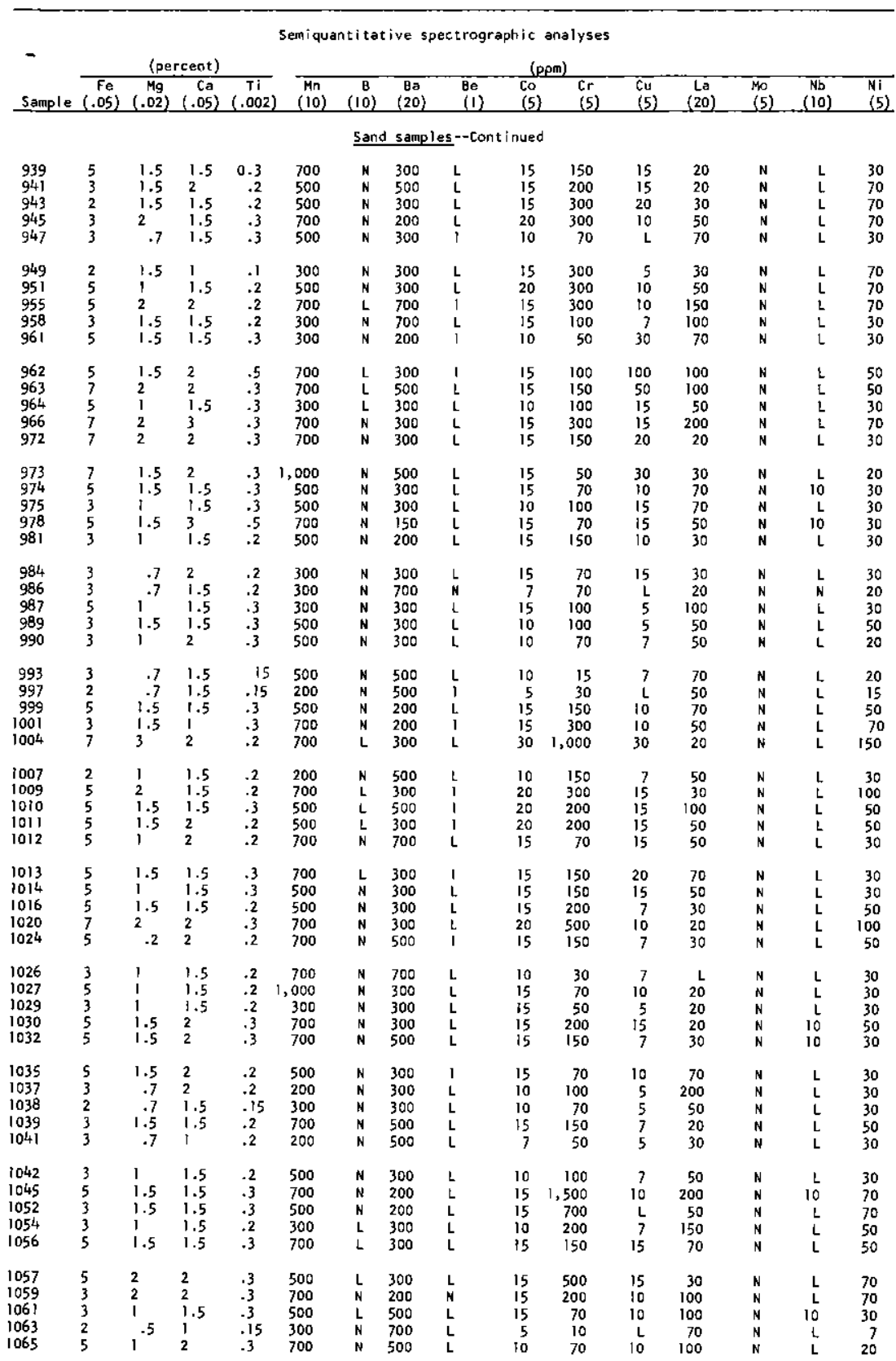


the Glacier Primitive Area, Fremont County-Continued

\begin{tabular}{|c|c|c|c|c|c|c|c|c|c|}
\hline \multirow[b]{2}{*}{ Sample } & \multicolumn{9}{|c|}{ Semiquantitative spectrographic analyses--Cont inued } \\
\hline & $\begin{array}{c}\mathrm{Pb} \\
(10)\end{array}$ & $\begin{array}{l}5 c \\
(5)\end{array}$ & 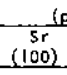 & $\begin{array}{l}\frac{v}{v} \\
(10)\end{array}$ & $\begin{array}{c}Y \\
(10)\end{array}$ & $\begin{array}{c}2 \\
(10) \\
\end{array}$ & $\frac{(\mathrm{ppm})}{\mathrm{C} \times \mathrm{HM}}$ & $\begin{array}{c}\text { Location } \\
\text { Sec-Twp-Rge }\end{array}$ & Drainage basir \\
\hline \multicolumn{10}{|c|}{ Sand samples--Cont inued } \\
\hline $\begin{array}{l}939 \\
941 \\
943 \\
945 \\
947\end{array}$ & $\begin{array}{l}20 \\
15 \\
15 \\
30 \\
20\end{array}$ & $\begin{array}{l}15 \\
10 \\
10 \\
15 \\
10\end{array}$ & $\begin{array}{r}150 \\
100 \\
L \\
L \\
200\end{array}$ & $\begin{array}{l}70 \\
50 \\
30 \\
70 \\
50\end{array}$ & $\begin{array}{l}20 \\
10 \\
30 \\
30 \\
30\end{array}$ & $\begin{array}{r}100 \\
50 \\
100 \\
150 \\
150\end{array}$ & $\begin{array}{l}1 \\
1 \\
3 \\
3 \\
1\end{array}$ & $\begin{array}{l}21-37-106 \\
21-37-106 \\
22-37-106 \\
27-37-106 \\
26-37-106\end{array}$ & $\begin{array}{l}\text { Bull Lake } \mathrm{Cr} \text {. } \\
\text { Do. } \\
\text { Do. } \\
\text { Do. } \\
\text { Do. }\end{array}$ \\
\hline $\begin{array}{l}949 \\
951 \\
955 \\
958 \\
961\end{array}$ & $\begin{array}{l}15 \\
15 \\
30 \\
20 \\
20\end{array}$ & $\begin{array}{r}10 \\
15 \\
15 \\
15 \\
7\end{array}$ & $\begin{array}{l}100 \\
200 \\
300 \\
100\end{array}$ & $\begin{array}{l}20 \\
70 \\
70 \\
50 \\
50\end{array}$ & $\begin{array}{l}10 \\
30 \\
30 \\
30 \\
30\end{array}$ & $\begin{array}{r}100 \\
20 \\
200 \\
70 \\
150\end{array}$ & $\begin{array}{l}3 \\
3 \\
5 \\
5 \\
5\end{array}$ & $\begin{array}{r}21-37-106 \\
20-38-105 \\
14-37-106 \\
7-36-106 \\
18-36-106\end{array}$ & $\begin{array}{l}\text { Do. } \\
\text { Dry Cr. } \\
\text { Do. } \\
\text { Bull Lake Cr. } \\
\text { Do. }\end{array}$ \\
\hline $\begin{array}{l}962 \\
963 \\
964 \\
966 \\
972\end{array}$ & $\begin{array}{r}150 \\
50 \\
15 \\
20 \\
20\end{array}$ & $\begin{array}{l}15 \\
20 \\
15 \\
30 \\
15\end{array}$ & $\begin{array}{l}150 \\
200 \\
100 \\
100 \\
150\end{array}$ & $\begin{array}{r}70 \\
100 \\
70 \\
100 \\
70\end{array}$ & $\begin{array}{l}30 \\
30 \\
20 \\
30 \\
15\end{array}$ & $\begin{array}{l}300 \\
150 \\
150 \\
150 \\
150\end{array}$ & $\begin{array}{r}14 \\
5 \\
3 \\
5 \\
3\end{array}$ & $\begin{array}{l}17-36-106 \\
17-36-106 \\
15-36-106 \\
10-36-106 \\
22-36-106\end{array}$ & $\begin{array}{l}\text { Do. } \\
\text { Do. } \\
\text { Do. } \\
\text { Do. } \\
\text { Do. }\end{array}$ \\
\hline $\begin{array}{l}973 \\
974 \\
975 \\
978 \\
981\end{array}$ & $\begin{array}{l}15 \\
30 \\
30 \\
15 \\
15\end{array}$ & $\begin{array}{l}15 \\
15 \\
10 \\
30 \\
10\end{array}$ & $\begin{array}{l}200 \\
300 \\
200 \\
100 \\
150\end{array}$ & $\begin{array}{r}70 \\
70 \\
70 \\
100 \\
70\end{array}$ & $\begin{array}{l}20 \\
30 \\
15 \\
70 \\
15\end{array}$ & $\begin{array}{r}150 \\
200 \\
70 \\
300 \\
200\end{array}$ & $\begin{array}{l}3 \\
9 \\
3 \\
3 \\
5\end{array}$ & $\begin{array}{l}22-36-106 \\
22-36-106 \\
22-36-106 \\
23-36-106 \\
23-36=106\end{array}$ & $\begin{array}{l}\text { Do. } \\
\text { Do. } \\
\text { Do. } \\
\text { Do. } \\
\text { Do. }\end{array}$ \\
\hline $\begin{array}{l}984 \\
986 \\
987 \\
989 \\
990\end{array}$ & $\begin{array}{l}15 \\
15 \\
15 \\
15 \\
20\end{array}$ & $\begin{array}{r}10 \\
5 \\
15 \\
15 \\
7\end{array}$ & $\begin{array}{l}200 \\
150 \\
150 \\
150 \\
200\end{array}$ & $\begin{array}{l}50 \\
15 \\
70 \\
70 \\
50\end{array}$ & $\begin{array}{l}20 \\
15 \\
20 \\
30 \\
20\end{array}$ & $\begin{array}{r}70 \\
70 \\
150 \\
70 \\
70\end{array}$ & $\begin{array}{l}3 \\
1 \\
1 \\
1 \\
3\end{array}$ & $\begin{array}{r}29-36-106 \\
28-36-106 \\
20-36-106 \\
21-36-106 \\
4-35-106\end{array}$ & $\begin{array}{l}\text { Do. } \\
\text { Do. } \\
\text { Do. } \\
\text { Do. } \\
\text { Do. }\end{array}$ \\
\hline $\begin{array}{r}993 \\
997 \\
999 \\
1001 \\
1004\end{array}$ & $\begin{array}{l}15 \\
15 \\
20 \\
30 \\
30\end{array}$ & $\begin{array}{l}10 \\
10 \\
15 \\
10 \\
20\end{array}$ & $\begin{array}{r}200 \\
300 \\
150 \\
100 \\
L\end{array}$ & $\begin{array}{r}50 \\
30 \\
70 \\
70 \\
100\end{array}$ & $\begin{array}{l}20 \\
10 \\
20 \\
20 \\
20\end{array}$ & $\begin{array}{r}150 \\
50 \\
50 \\
150 \\
100\end{array}$ & $\begin{array}{l}1 \\
5 \\
7 \\
2 \\
7\end{array}$ & $\begin{array}{l}5-35-106 \\
30-36-106 \\
21-36-106 \\
28-37-105 \\
29-37-105\end{array}$ & $\begin{array}{l}\text { Bull Lake Cr. } \\
\text { Do. } \\
\text { Do. } \\
\text { Do. } \\
\text { Do. }\end{array}$ \\
\hline $\begin{array}{l}1007 \\
1009 \\
1010 \\
1011 \\
1012\end{array}$ & $\begin{array}{l}20 \\
50 \\
30 \\
50 \\
50\end{array}$ & $\begin{array}{l}10 \\
20 \\
20 \\
20 \\
15\end{array}$ & $\begin{array}{r}300 \\
L \\
150 \\
200 \\
200\end{array}$ & $\begin{array}{l}30 \\
70 \\
70 \\
70 \\
70\end{array}$ & $\begin{array}{l}20 \\
20 \\
30 \\
20 \\
20\end{array}$ & $\begin{array}{l}100 \\
300 \\
300 \\
200 \\
150\end{array}$ & $\begin{array}{l}5 \\
5 \\
5 \\
5 \\
3\end{array}$ & $\begin{array}{r}29-37-105 \\
8-36-106 \\
17-36-106 \\
17-36-106 \\
16-36-106\end{array}$ & $\begin{array}{l}\text { Do. } \\
\text { Do. } \\
\text { Do. } \\
\text { Do. } \\
\text { Do. }\end{array}$ \\
\hline $\begin{array}{l}1013 \\
1014 \\
1016 \\
1020 \\
1024\end{array}$ & $\begin{array}{r}100 \\
50 \\
20 \\
20 \\
20\end{array}$ & $\begin{array}{l}15 \\
15 \\
15 \\
20 \\
15\end{array}$ & $\begin{array}{l}150 \\
200 \\
100 \\
100 \\
300\end{array}$ & $\begin{array}{l}70 \\
70 \\
70 \\
70 \\
70\end{array}$ & $\begin{array}{l}20 \\
20 \\
20 \\
20 \\
20\end{array}$ & $\begin{array}{r}100 \\
150 \\
70 \\
200 \\
200\end{array}$ & $\begin{array}{l}5 \\
5 \\
3 \\
5 \\
3\end{array}$ & $\begin{array}{c}16-36-106 \\
16-36-106 \\
2-36-106 \\
32-37-105 \\
3-15-6\end{array}$ & $\begin{array}{l}\text { Do. } \\
\text { Do. } \\
\text { Do. } \\
\text { Do. } \\
\text { Do. }\end{array}$ \\
\hline $\begin{array}{l}1026 \\
1027 \\
1029 \\
1030 \\
1032\end{array}$ & $\begin{array}{l}20 \\
30 \\
15 \\
30 \\
30\end{array}$ & $\begin{array}{l}7 \\
15 \\
15 \\
15 \\
15\end{array}$ & $\begin{array}{l}200 \\
200 \\
200 \\
200 \\
150\end{array}$ & $\begin{array}{l}50 \\
70 \\
50 \\
70 \\
70\end{array}$ & $\begin{array}{l}15 \\
30 \\
30 \\
30 \\
30\end{array}$ & $\begin{array}{r}50 \\
70 \\
100 \\
150 \\
50\end{array}$ & $\begin{array}{l}5 \\
5 \\
5 \\
3 \\
3\end{array}$ & $\begin{array}{r}12-35-106 \\
1-35-106 \\
2-35-106 \\
35-36-106 \\
32-36-106\end{array}$ & $\begin{array}{l}\text { Do. } \\
\text { Do. } \\
\text { Do. } \\
\text { Do. } \\
\text { Do. }\end{array}$ \\
\hline $\begin{array}{l}1035 \\
1037 \\
1038 \\
1039 \\
1041\end{array}$ & $\begin{array}{l}50 \\
15 \\
15 \\
30 \\
15\end{array}$ & $\begin{array}{l}15 \\
10 \\
15 \\
15 \\
10\end{array}$ & $\begin{array}{l}200 \\
150 \\
200 \\
200 \\
200\end{array}$ & $\begin{array}{l}50 \\
50 \\
30 \\
30 \\
30\end{array}$ & $\begin{array}{l}30 \\
20 \\
20 \\
30 \\
10\end{array}$ & $\begin{array}{l}100 \\
150 \\
100 \\
100 \\
100\end{array}$ & $\begin{array}{l}3 \\
3 \\
3 \\
3 \\
1\end{array}$ & $\begin{array}{r}32-36-106 \\
32-36-106 \\
33-36-106 \\
33-36-106 \\
4-35-106\end{array}$ & $\begin{array}{l}\text { Do. } \\
\text { Do. } \\
\text { Do. } \\
\text { Do. } \\
\text { Do. }\end{array}$ \\
\hline $\begin{array}{l}1042 \\
1045 \\
1052 \\
1054 \\
1056\end{array}$ & $\begin{array}{l}30 \\
15 \\
15 \\
20 \\
15\end{array}$ & $\begin{array}{l}10 \\
20 \\
15 \\
10 \\
15\end{array}$ & $\begin{array}{l}150 \\
100 \\
150 \\
150 \\
150\end{array}$ & $\begin{array}{l}50 \\
70 \\
70 \\
50 \\
70\end{array}$ & $\begin{array}{r}30 \\
100 \\
30 \\
20 \\
20\end{array}$ & $\begin{array}{r}100 \\
200 \\
150 \\
70 \\
150\end{array}$ & $\begin{array}{l}3 \\
3 \\
1 \\
3 \\
9\end{array}$ & $\begin{array}{r}4-35-106 \\
6-37-105 \\
20-38-105 \\
4-37-105 \\
34-3-6\end{array}$ & $\begin{array}{l}\text { Do. } \\
\text { Dry Cr. } \\
\text { Do. } \\
\text { Dob Cr. } \\
\text { Do. }\end{array}$ \\
\hline $\begin{array}{l}1057 \\
1059 \\
1061 \\
1063 \\
1065\end{array}$ & $\begin{array}{l}30 \\
15 \\
30 \\
15 \\
30\end{array}$ & $\begin{array}{r}15 \\
15 \\
15 \\
5 \\
15\end{array}$ & $\begin{array}{l}200 \\
150 \\
300 \\
500 \\
500\end{array}$ & $\begin{array}{r}100 \\
100 \\
100 \\
30 \\
100\end{array}$ & $\begin{array}{l}30 \\
15 \\
30 \\
30 \\
50\end{array}$ & $\begin{array}{r}70 \\
200 \\
100 \\
20 \\
70\end{array}$ & $\begin{array}{r}3 \\
3 \\
5 \\
1 \\
11\end{array}$ & $\begin{array}{r}16-37-105 \\
15-36-106 \\
8-35-106 \\
9-35-106 \\
9-35-106\end{array}$ & $\begin{array}{l}\text { Do. } \\
\text { Bull Lake Cr. } \\
\text { Do. } \\
\text { Do. } \\
\text { Do. }\end{array}$ \\
\hline
\end{tabular}


Semiquantitative spectrographic analyses

\begin{tabular}{|c|c|c|c|c|c|c|c|c|c|c|c|c|c|c|c|}
\hline \multirow[b]{2}{*}{ Sample } & \multicolumn{4}{|c|}{ (percent) } & \multicolumn{10}{|c|}{ (ppm) } & \\
\hline & $\begin{array}{c}\mathrm{Fe} \\
(.05)\end{array}$ & $\begin{array}{c}\mathrm{Mg} \\
(.02)\end{array}$ & $\begin{array}{c}\mathrm{Ca} \\
(.05)\end{array}$ & $\begin{array}{c}\mathrm{Ti} \\
(.002)\end{array}$ & $\begin{array}{c}M n \\
(10)\end{array}$ & $\begin{array}{c}\mathbf{B} \\
(10)\end{array}$ & $\begin{array}{c}\mathrm{Ba} \\
(20)\end{array}$ & $\begin{array}{l}\mathrm{Be} \\
\text { (I) }\end{array}$ & $\begin{array}{l}\text { Co } \\
\text { (5) }\end{array}$ & $\begin{array}{l}\mathrm{Cr} \\
(5)\end{array}$ & $\begin{array}{l}\mathrm{Cu} \\
(5)\end{array}$ & $\begin{array}{c}\mathrm{La} \\
(20)\end{array}$ & $\begin{array}{l}\text { Mo } \\
\text { (5) }\end{array}$ & $\begin{array}{c}\mathrm{Nb} \\
(10\}\end{array}$ & $\begin{array}{l}\mathrm{Ni} \\
(5)\end{array}$ \\
\hline
\end{tabular}

Sand samples--Continued

$\begin{array}{llllll}1067 & 3 & 1 & 1.5 & .2 & 500 \\ 1068 & 3 & 1 & 1.5 & .3 & 500 \\ 1069 & 1.5 & .7 & 1 & .15 & 200 \\ 1072 & 2 & .7 & 1 & .2 & 150 \\ 1078 & 3 & 1 & 1.5 & .3 & 500 \\ 1079 & 1 & .5 & .5 & .07 & 150 \\ 1081 & 2 & .5 & 1.5 & .2 & 300 \\ 1002 & 5 & 1 & 1.5 & .3 & 700 \\ 1083 & 3 & 1.5 & 2 & .3 & 700 \\ 1084 & 2 & .5 & 2 & .1 & 200 \\ 1085 & 1 & .5 & 2 & .1 & 200 \\ 1088 & 1.5 & .3 & 1 & .15 & 1,000 \\ 1090 & 5 & 5 & 7 & .3 & 1,000 \\ 1091 & 3 & 1 & 3 & .2 & 700 \\ 1092 & 3 & 1 & 2 & .2 & 300\end{array}$

\begin{tabular}{|c|c|c|c|c|c|c|c|c|c|}
\hline N & 300 & I & 20 & 100 & 7 & 100 & $\mathbf{N}$ & 10 & So \\
\hline N & 300 & L & 10 & 100 & 7 & 70 & $\mathbf{N}$ & L & 30 \\
\hline $\mathbf{N}$ & 500 & $\mathrm{~N}$ & 5 & 20 & $i$ & 50 & $\mathbf{N}$ & L & 10 \\
\hline N & 300 & L & 5 & 30 & L & 50 & N & $L$ & 15 \\
\hline N & 300 & l & 10 & 30 & 7 & 50 & $\mathbf{N}$ & $l$ & 30 \\
\hline N & 300 & $\mathbf{N}$ & $\mathbf{H}$ & 7 & $\mathbf{N}$ & L & $N$ & $\mathbf{N}$ & 7 \\
\hline N & 500 & L & 7 & 7 & L & 70 & $\mathbf{N}$ & L & 10 \\
\hline L & 500 & L & 15 & 50 & 7 & 100 & $\mathrm{~N}$ & L & 20 \\
\hline $\mathrm{N}$ & 300 & L & 15 & 300 & 7 & 100 & $\mathbf{N}$ & L & 70 \\
\hline N & 700 & L & 7 & 15 & L & L & $N$ & L & 15 \\
\hline N & 1,000 & L & L & 15 & $\mathbf{N}$ & $\mathbf{N}$ & $N$ & L. & 10 \\
\hline L & 150 & 1 & 10 & 30 & 15 & 100 & $\mathbf{N}$ & L & 15 \\
\hline $\mathrm{N}$ & 200 & L & 20 & 500 & 10 & 150 & $\mathbf{N}$ & L & 150 \\
\hline N & 700 & L & 15 & 100 & 7 & 70 & $\mathbf{N}$ & 2 & 30 \\
\hline N & 500 & L & 10 & 70 & 5 & 150 & $N$ & L & 30 \\
\hline
\end{tabular}

\section{Organic sand samples}

\begin{tabular}{|c|c|c|c|c|c|c|c|c|c|c|c|c|c|c|}
\hline $\begin{array}{l}208 \\
209 \\
217 \\
218 \\
219\end{array}$ & $\begin{array}{l}3 \\
2 \\
3 \\
1.5 \\
1.5\end{array}$ & $\begin{array}{r}1 \\
.3 \\
1.5 \\
.2 \\
.7\end{array}$ & $\begin{array}{l}1 \\
1 \\
1.5 \\
.2 \\
.7\end{array}$ & $\begin{array}{c}0.2 \\
.3 \\
.2 \\
.2 \\
.15\end{array}$ & $\begin{array}{l}300 \\
100 \\
500 \\
150 \\
200\end{array}$ & $\begin{array}{r}\text { L } \\
N \\
L \\
70 \\
N\end{array}$ & $\begin{array}{l}500 \\
300 \\
300 \\
700 \\
300\end{array}$ & $\begin{array}{l}\text { L } \\
\text { L } \\
\text { l. } \\
\text { L }\end{array}$ & $\begin{array}{r}15 \\
5 \\
15 \\
10 \\
10\end{array}$ & $\begin{array}{r}70 \\
15 \\
300 \\
30 \\
30\end{array}$ & $\begin{array}{l}30 \\
10 \\
15 \\
15 \\
15\end{array}$ & $\begin{array}{r}70 \\
150 \\
30 \\
30 \\
30\end{array}$ & $\begin{array}{l}N \\
N \\
N \\
N \\
15\end{array}$ & $\begin{array}{r}\mathrm{L} \\
\mathrm{L} \\
\mathrm{L} \\
10 \\
\mathrm{~L}\end{array}$ \\
\hline $\begin{array}{l}220 \\
229 \\
230 \\
231 \\
237\end{array}$ & $\begin{array}{l}3 \\
1.5 \\
1.5 \\
1.5 \\
3\end{array}$ & $\begin{array}{l}1 \\
2 \\
1.5 \\
2.5 \\
1.5\end{array}$ & $\begin{array}{l}1 \\
2 \\
2 \\
2 \\
\quad .7\end{array}$ & $\begin{array}{l}.2 \\
.15 \\
.1 \\
.1 \\
.2\end{array}$ & $\begin{array}{l}300 \\
300 \\
300 \\
200 \\
300\end{array}$ & $\begin{array}{r}L \\
50 \\
30 \\
30 \\
L\end{array}$ & $\begin{array}{l}300 \\
700 \\
300 \\
300 \\
300\end{array}$ & $\begin{array}{l}1 \\
1 \\
L \\
L \\
1\end{array}$ & $\begin{array}{r}15 \\
7 \\
5 \\
5 \\
15\end{array}$ & $\begin{array}{l}70 \\
30 \\
20 \\
30 \\
70\end{array}$ & $\begin{array}{r}20 \\
10 \\
5 \\
7 \\
15\end{array}$ & $\begin{array}{r}50 \\
20 \\
20 \\
L \\
50\end{array}$ & $\begin{array}{l}\mathbf{N} \\
\mathbf{N} \\
\mathbf{N} \\
\mathrm{N} \\
\mathrm{N}\end{array}$ & $\begin{array}{l}L \\
L \\
L \\
\text { H } \\
L\end{array}$ \\
\hline $\begin{array}{l}238 \\
239 \\
241 \\
242 \\
243\end{array}$ & $\begin{array}{l}3 \\
3 \\
3 \\
.7 \\
1.5\end{array}$ & $\begin{array}{l}1 \\
1 \\
1.5 \\
.3 \\
.5\end{array}$ & $\begin{array}{l}1.5 \\
1 \\
.5 \\
.7\end{array}$ & $\begin{array}{l}.15 \\
.15 \\
.3 \\
.07 \\
.1\end{array}$ & $\begin{array}{l}300 \\
300 \\
500 \\
200 \\
150\end{array}$ & $\begin{array}{c}70 \\
\text { L } \\
\text { N } \\
\text { L } \\
\text { L }\end{array}$ & $\begin{array}{l}700 \\
300 \\
300 \\
100 \\
150\end{array}$ & $\begin{array}{l}1 \\
1 \\
1 \\
L \\
L\end{array}$ & $\begin{array}{l}15 \\
15 \\
15 \\
1 \\
5\end{array}$ & $\begin{array}{r}70 \\
70 \\
150 \\
15 \\
7\end{array}$ & $\begin{array}{r}10 \\
10 \\
10 \\
10 \\
7\end{array}$ & $\begin{array}{r}30 \\
70 \\
100 \\
100 \\
30\end{array}$ & $\begin{array}{l}\mathbf{N} \\
\mathbf{N} \\
\mathbf{N} \\
\mathbf{N} \\
\mathbf{N}\end{array}$ & $\begin{array}{l}\text { L } \\
\text { L } \\
\text { L } \\
\mathbf{N} \\
\mathbf{N}\end{array}$ \\
\hline $\begin{array}{l}246 \\
248 \\
249 \\
250 \\
251\end{array}$ & $\begin{array}{l}1.5 \\
3 \\
1.5 \\
3 \\
3\end{array}$ & $\begin{array}{l}.3 \\
1.5 \\
2.3 \\
1.5\end{array}$ & $\begin{array}{r}.7 \\
1.5 \\
.3 \\
1.5 \\
1\end{array}$ & $\begin{array}{l}.15 \\
.3 \\
.07 \\
.3 \\
.15\end{array}$ & $\begin{array}{l}300 \\
500 \\
300 \\
500 \\
700\end{array}$ & $\begin{array}{l}\mathbf{N} \\
\mathbf{N} \\
\mathbf{N} \\
\mathbf{N} \\
\mathbf{N}\end{array}$ & $\begin{array}{l}300 \\
700 \\
100 \\
500 \\
100\end{array}$ & $\begin{array}{l}L \\
\text { L } \\
L \\
L\end{array}$ & $\begin{array}{r}5 \\
15 \\
5 \\
15 \\
20\end{array}$ & $\begin{array}{r}50 \\
150 \\
20 \\
50 \\
200\end{array}$ & $\begin{array}{r}7 \\
15 \\
5 \\
10 \\
15\end{array}$ & $\begin{array}{r}70 \\
100 \\
\mathrm{~L} \\
70 \\
50\end{array}$ & $\begin{array}{l}\mathbf{N} \\
\mathbf{N} \\
\mathrm{N} \\
\mathrm{N} \\
\mathrm{N}\end{array}$ & $\begin{array}{l}\mathrm{L} \\
\mathbf{L} \\
\mathbf{N} \\
\mathbf{L} \\
\mathbf{L}\end{array}$ \\
\hline $\begin{array}{l}252 \\
297 \\
299 \\
323 \\
332\end{array}$ & $\begin{array}{l}3 \\
3 \\
2 \\
1.5 \\
3\end{array}$ & $\begin{array}{l}\text { I } \\
1.5 \\
1.3 \\
.7\end{array}$ & $\begin{array}{l}.7 \\
1.5 \\
1 \\
1 \\
.7\end{array}$ & $\begin{array}{l}.2 \\
.5 \\
.3 \\
.15 \\
.3\end{array}$ & $\begin{array}{l}300 \\
500 \\
200 \\
300 \\
200\end{array}$ & $\begin{array}{c}\mathbf{N} \\
\mathbf{N} \\
\mathbf{N} \\
\mathrm{L} \\
10\end{array}$ & $\begin{array}{l}200 \\
300 \\
300 \\
150 \\
300\end{array}$ & $\begin{array}{l}L \\
1.5 \\
1 \\
L \\
1.5\end{array}$ & $\begin{array}{r}10 \\
15 \\
10 \\
5 \\
15\end{array}$ & $\begin{array}{r}150 \\
150 \\
50 \\
20 \\
50\end{array}$ & $\begin{array}{r}15 \\
30 \\
15 \\
7 \\
30\end{array}$ & $\begin{array}{r}50 \\
100 \\
100 \\
50 \\
150\end{array}$ & $\begin{array}{l}\mathrm{L} \\
\mathrm{N} \\
\mathrm{N} \\
\mathrm{N} \\
\mathrm{N}\end{array}$ & $\begin{array}{r}\mathrm{N} \\
10 \\
\mathrm{~L} \\
\mathrm{~L} \\
10\end{array}$ \\
\hline $\begin{array}{l}338 \\
364 \\
373 \\
374 \\
381\end{array}$ & $\begin{array}{l}3 \\
2 \\
3 \\
2 \\
3\end{array}$ & $i^{.7} .7$ & $\begin{array}{l}1.5 \\
.7 \\
1 \\
.7\end{array}$ & $\begin{array}{l}.15 \\
.15 \\
.3 \\
.2 \\
.2\end{array}$ & $\begin{array}{l}300 \\
300 \\
300 \\
300 \\
500\end{array}$ & $\begin{array}{c}\mathrm{L} \\
\mathrm{L} \\
\mathrm{N} \\
\mathrm{N} \\
\mathrm{IS}\end{array}$ & $\begin{array}{l}200 \\
200 \\
200 \\
200 \\
500\end{array}$ & $\begin{array}{l}1 \\
L \\
1 \\
L \\
1.5\end{array}$ & $\begin{array}{l}15 \\
15 \\
20 \\
20 \\
20\end{array}$ & $\begin{array}{r}70 \\
15 \\
200 \\
70 \\
50\end{array}$ & $\begin{array}{r}30 \\
5 \\
20 \\
15 \\
30\end{array}$ & $\begin{array}{l}70 \\
30 \\
30 \\
20 \\
70\end{array}$ & $\begin{array}{l}\mathrm{L} \\
\mathrm{N} \\
\mathrm{N} \\
\mathrm{N} \\
\mathbf{N}\end{array}$ & $\begin{array}{l}\mathrm{L} \\
\mathrm{L} \\
\mathrm{L} \\
\mathrm{L} \\
\mathrm{L}\end{array}$ \\
\hline $\begin{array}{l}603 \\
613 \\
617 \\
619 \\
625\end{array}$ & $\begin{array}{l}5 \\
3 \\
3 \\
1.5 \\
3\end{array}$ & $\begin{array}{l}1.5 \\
1.5 \\
1.5 \\
1.2\end{array}$ & $\begin{array}{l}1.5 \\
1.5 \\
1.5 \\
.7 \\
1.5\end{array}$ & $\begin{array}{l}.5 \\
.3 \\
.3 \\
.3 \\
.3\end{array}$ & $\begin{array}{l}300 \\
700 \\
500 \\
300 \\
500\end{array}$ & $\begin{array}{l}\mathbf{L} \\
\mathbf{N} \\
\mathbf{L} \\
\mathbf{N} \\
\mathbf{N}\end{array}$ & $\begin{array}{l}300 \\
300 \\
300 \\
200 \\
300\end{array}$ & $\begin{array}{l}1.5 \\
L \\
1 \\
1 \\
1\end{array}$ & $\begin{array}{r}30 \\
20 \\
30 \\
7 \\
15\end{array}$ & $\begin{array}{r}200 \\
700 \\
200 \\
15 \\
150\end{array}$ & $\begin{array}{r}30 \\
10 \\
15 \\
7 \\
30\end{array}$ & $\begin{array}{r}50 \\
100 \\
50 \\
20 \\
50\end{array}$ & $\begin{array}{l}\mathrm{N} \\
\mathrm{N} \\
\mathrm{N} \\
\mathrm{N} \\
\mathrm{N}\end{array}$ & $\begin{array}{l}\text { L } \\
\text { L } \\
\text { L } \\
\text { L }\end{array}$ \\
\hline $\begin{array}{l}633 \\
635 \\
638 \\
639 \\
640\end{array}$ & $\begin{array}{l}3 \\
3 \\
3 \\
3 \\
3\end{array}$ & $\begin{array}{l}.7 \\
1.5 \\
1 \\
1 \\
1\end{array}$ & $\begin{array}{l}.7 \\
1 \\
1.5\end{array}$ & $\begin{array}{l}.3 \\
.5 \\
.3 \\
.5 \\
.3\end{array}$ & $\begin{array}{l}150 \\
300 \\
500 \\
500 \\
700\end{array}$ & $\begin{array}{c}10 \\
15 \\
N \\
L \\
N\end{array}$ & $\begin{array}{l}300 \\
200 \\
150 \\
200 \\
200\end{array}$ & $\begin{array}{l}1 \\
1.5 \\
1 \\
1 \\
1\end{array}$ & $\begin{array}{l}10 \\
20 \\
15 \\
15 \\
15\end{array}$ & $\begin{array}{l}150 \\
200 \\
150 \\
150 \\
150\end{array}$ & $\begin{array}{l}15 \\
20 \\
15 \\
20 \\
15\end{array}$ & $\begin{array}{r}150 \\
70 \\
50 \\
50 \\
70\end{array}$ & $\begin{array}{l}S \\
N \\
N \\
N \\
N\end{array}$ & $\begin{array}{r}\mathrm{L} \\
\mathrm{L} \\
\mathrm{L} \\
10 \\
\mathrm{~L}\end{array}$ \\
\hline
\end{tabular}


Semiquantitative spectrograghic analyses--Continued

\begin{tabular}{|c|c|c|c|c|c|c|c|c|c|}
\hline \multirow[b]{2}{*}{ Sample } & \multicolumn{6}{|c|}{$(\mathrm{gpm})$} & \multirow{2}{*}{$\frac{(\mathrm{ppm})}{\mathrm{C} \times \mathrm{HH}}$} & \multirow[b]{2}{*}{$\begin{array}{c}\text { Location } \\
\text { Sec-Twp-Rge }\end{array}$} & \multirow[b]{2}{*}{ Drainage basin } \\
\hline & $\begin{array}{l}\mathrm{Pb} \\
(10)\end{array}$ & $\begin{array}{l}5 c \\
(5) \\
\end{array}$ & $\begin{array}{c}5 r \\
(100)\end{array}$ & $(10)$ & $\begin{array}{r}y \\
(10)\end{array}$ & $\begin{array}{c}7 \mathrm{Zr} \\
(10)\end{array}$ & & & \\
\hline \multicolumn{10}{|c|}{ Sand samples--Cont inued } \\
\hline $\begin{array}{l}1067 \\
1068 \\
1069 \\
1072 \\
1078\end{array}$ & $\begin{array}{l}30 \\
15 \\
20 \\
15 \\
20\end{array}$ & $\begin{array}{r}10 \\
15 \\
7 \\
7 \\
10\end{array}$ & $\begin{array}{l}300 \\
200 \\
500 \\
200 \\
300\end{array}$ & $\begin{array}{l}70 \\
70 \\
30 \\
30 \\
70\end{array}$ & $\begin{array}{l}50 \\
30 \\
20 \\
20 \\
30\end{array}$ & $\begin{array}{r}200 \\
150 \\
70 \\
150 \\
100\end{array}$ & $\begin{array}{r}11 \\
3 \\
3 \\
3 \\
3\end{array}$ & $\begin{array}{l}4-35-106 \\
4-35-106 \\
3-35-106 \\
3-35-106 \\
7-35-106\end{array}$ & $\begin{array}{l}\text { Bull Lake Cr. } \\
\text { D. } \\
\text { D. } \\
\infty . \\
\text { D. }\end{array}$ \\
\hline $\begin{array}{l}1079 \\
1081 \\
1082 \\
1083 \\
1084\end{array}$ & $\begin{array}{l}10 \\
20 \\
50 \\
30 \\
15\end{array}$ & $\begin{array}{r}5 \\
\mathrm{~L} \\
10 \\
20 \\
7\end{array}$ & $\begin{array}{l}150 \\
500 \\
700 \\
200 \\
500\end{array}$ & $\begin{array}{l}15 \\
50 \\
70 \\
70 \\
20\end{array}$ & $\begin{array}{l}L \\
20 \\
30 \\
50 \\
15\end{array}$ & $\begin{array}{r}20 \\
70 \\
150 \\
150 \\
30\end{array}$ & $\begin{array}{l}3 \\
0.5 \\
4 \\
2 \\
5\end{array}$ & $\begin{array}{r}14-35-106 \\
15-35-106 \\
10-35-106 \\
30-37-106 \\
2-35-106\end{array}$ & $\begin{array}{l}\text { D. } \\
\text { D. } \\
\text { D. } \\
\text { D. } \\
\text { D. }\end{array}$ \\
\hline $\begin{array}{l}1085 \\
1088 \\
1090 \\
1091 \\
1092\end{array}$ & $\begin{array}{l}15 \\
30 \\
20 \\
20 \\
20\end{array}$ & $\begin{array}{r}N \\
7 \\
20 \\
15 \\
15\end{array}$ & $\begin{array}{r}500 \\
L \\
300 \\
300 \\
300\end{array}$ & $\begin{array}{l}15 \\
50 \\
70 \\
70 \\
50\end{array}$ & $\begin{array}{l}15 \\
30 \\
50 \\
50 \\
50\end{array}$ & $\begin{array}{l}30 \\
150 \\
150 \\
150 \\
150\end{array}$ & $\begin{array}{l}1 \\
6 \\
1 \\
1 \\
1\end{array}$ & $\begin{array}{l}35-36-106 \\
35-36-106 \\
36-1-106 \\
22-1-106 \\
15-1=106\end{array}$ & $\begin{array}{l}\text { Do. } \\
\text { Do. } \\
\text { Do. } \\
\text { Do. } \\
\text { Do. }\end{array}$ \\
\hline
\end{tabular}

\section{Organic sand samples}

\begin{tabular}{|c|c|c|c|c|c|c|c|c|c|}
\hline $\begin{array}{l}208 \\
209 \\
217 \\
218 \\
219\end{array}$ & $\begin{array}{l}50 \\
15 \\
20 \\
15 \\
30\end{array}$ & $\begin{array}{r}7 \\
5 \\
15 \\
5 \\
5\end{array}$ & $\begin{array}{r}150 \\
100 \\
100 \\
N \\
L\end{array}$ & $\begin{array}{l}70 \\
30 \\
70 \\
15 \\
30\end{array}$ & $\begin{array}{l}20 \\
70 \\
15 \\
30 \\
30\end{array}$ & $\begin{array}{l}100 \\
200 \\
150 \\
500 \\
100\end{array}$ & $\begin{array}{l}1 \\
1 \\
1 \\
1 \\
3\end{array}$ & $\begin{array}{l}17-38-106 \\
17-38-106 \\
8-38-105 \\
27-4-6 \\
27-39-106\end{array}$ & $\begin{array}{l}\text { Dimwoody } \mathrm{Cr} \text {. } \\
\text { Do. } \\
\text { Dry Cr. } \\
\text { Little Ory } \mathrm{Cr} \text {. } \\
\text { Dimwoody } \mathrm{Cr} \text {. }\end{array}$ \\
\hline $\begin{array}{l}220 \\
229 \\
230 \\
231 \\
237\end{array}$ & $\begin{array}{l}50 \\
30 \\
10 \\
20 \\
30\end{array}$ & $\begin{array}{l}7 \\
5 \\
5 \\
5 \\
7\end{array}$ & $\begin{array}{r}100 \\
\mathrm{~L} \\
\mathrm{~N} \\
\mathrm{~N} \\
\mathrm{~L}\end{array}$ & $\begin{array}{l}70 \\
20 \\
15 \\
10 \\
30\end{array}$ & $\begin{array}{l}30 \\
15 \\
15 \\
15 \\
30\end{array}$ & $\begin{array}{l}150 \\
150 \\
150 \\
100 \\
200\end{array}$ & $\begin{array}{l}3 \\
3 \\
1 \\
1 \\
1\end{array}$ & $\begin{array}{l}34-39-106 \\
24-40-106 \\
24-40-106 \\
18-40-105 \\
13-39-107\end{array}$ & $\begin{array}{l}\text { Do. } \\
\text { Blue Hole } \mathrm{Cr} \text {. } \\
\text { Do. } \\
\text { Do. } \\
\text { Torrey } \mathrm{Cr} \text {. }\end{array}$ \\
\hline $\begin{array}{l}238 \\
239 \\
241 \\
242 \\
243\end{array}$ & $\begin{array}{l}15 \\
30 \\
50 \\
15 \\
15\end{array}$ & $\begin{array}{r}7 \\
7 \\
10 \\
L \\
5\end{array}$ & $\begin{array}{r}L \\
L \\
100 \\
L \\
100\end{array}$ & $\begin{array}{l}20 \\
50 \\
70 \\
20 \\
15\end{array}$ & $\begin{array}{l}20 \\
30 \\
70 \\
15 \\
10\end{array}$ & $\begin{array}{l}100 \\
300 \\
500 \\
100 \\
150\end{array}$ & $\begin{array}{l}1 \\
1 \\
1 \\
1 \\
3\end{array}$ & $\begin{array}{l}20-40-106 \\
21-40-107 \\
16-40-107 \\
16-40-107 \\
16-40-107\end{array}$ & $\begin{array}{l}\text { Do. } \\
\text { Jakeys Fork. } \\
\text { Do. } \\
\text { Do. } \\
\text { Do. }\end{array}$ \\
\hline $\begin{array}{l}246 \\
248 \\
249 \\
250 \\
251\end{array}$ & $\begin{array}{l}20 \\
30 \\
10 \\
30 \\
10\end{array}$ & $\begin{array}{r}5 \\
7 \\
2 \\
10 \\
10\end{array}$ & $\begin{array}{r}\mathrm{L} \\
100 \\
N \\
150 \\
\mathrm{~L}\end{array}$ & $\begin{array}{l}30 \\
50 \\
15 \\
50 \\
70\end{array}$ & $\begin{array}{l}15 \\
50 \\
10 \\
20 \\
15\end{array}$ & $\begin{array}{r}150 \\
500 \\
100 \\
150 \\
70\end{array}$ & $\begin{array}{l}3 \\
1 \\
1 \\
1 \\
1\end{array}$ & $\begin{array}{r}11-40-i 07 \\
35-41-107 \\
17-40-107 \\
17-40-107 \\
8-40-107\end{array}$ & $\begin{array}{l}\text { Do. } \\
\text { Do. } \\
\text { Do. } \\
\text { Do. } \\
\text { Do. }\end{array}$ \\
\hline $\begin{array}{l}252 \\
297 \\
299 \\
323 \\
332\end{array}$ & $\begin{array}{l}10 \\
30 \\
30 \\
30 \\
30\end{array}$ & $\begin{array}{r}7 \\
15 \\
10 \\
5 \\
10\end{array}$ & $\begin{array}{r}100 \\
150 \\
100 \\
N \\
100\end{array}$ & $\begin{array}{l}50 \\
70 \\
50 \\
20 \\
70\end{array}$ & $\begin{array}{l}30 \\
30 \\
20 \\
30 \\
50\end{array}$ & $\begin{array}{l}150 \\
300 \\
200 \\
100 \\
200\end{array}$ & $\begin{array}{l}1 \\
2 \\
2 \\
8 \\
1\end{array}$ & $\begin{array}{r}5-40-107 \\
1-39-108 \\
6-39-107 \\
9-38-106 \\
28-38-106\end{array}$ & $\begin{array}{l}\text { Do. } \\
\text { Do. } \\
\text { Do. } \\
\text { Dimwoody Cr. } \\
\text { Do. }\end{array}$ \\
\hline $\begin{array}{l}338 \\
364 \\
373 \\
374 \\
381\end{array}$ & $\begin{array}{l}30 \\
15 \\
20 \\
15 \\
70\end{array}$ & $\begin{array}{r}7 \\
7 \\
10 \\
7 \\
7\end{array}$ & $\begin{array}{r}100 \\
100 \\
L \\
100 \\
100\end{array}$ & $\begin{array}{l}30 \\
20 \\
50 \\
50 \\
50\end{array}$ & $\begin{array}{l}30 \\
15 \\
30 \\
15 \\
20\end{array}$ & $\begin{array}{r}150 \\
100 \\
150 \\
70 \\
150\end{array}$ & $\begin{array}{l}1 \\
1 \\
1 \\
1 \\
1\end{array}$ & $\begin{array}{r}22-39-106 \\
9-40-107 \\
12-38-106 \\
11-38-106 \\
24-39-107\end{array}$ & $\begin{array}{l}\text { D. } \\
\text { Jakeys Fork. } \\
\text { Dinwoody Cr. } \\
\text { Do. } \\
\text { Torrey Cr. }\end{array}$ \\
\hline $\begin{array}{l}603 \\
613 \\
617 \\
619 \\
625\end{array}$ & $\begin{array}{l}30 \\
15 \\
15 \\
10 \\
15\end{array}$ & $\begin{array}{r}20 \\
15 \\
15 \\
7 \\
15\end{array}$ & $\begin{array}{l}100 \\
100 \\
200 \\
100 \\
150\end{array}$ & $\begin{array}{r}150 \\
70 \\
70 \\
50 \\
70\end{array}$ & $\begin{array}{l}20 \\
20 \\
15 \\
15 \\
15\end{array}$ & $\begin{array}{l}700 \\
150 \\
200 \\
700 \\
100\end{array}$ & $\begin{array}{r}1 \\
3 \\
1 \\
10 \\
3\end{array}$ & $\begin{array}{l}29-40-107 \\
34-41-108 \\
27-41-108 \\
28-41-108 \\
29-41-108\end{array}$ & $\begin{array}{l}\text { Jakeys Fork. } \\
\text { Warm Spg Cr. } \\
\text { Do. } \\
\text { Do. } \\
\text { D. }\end{array}$ \\
\hline $\begin{array}{l}633 \\
635 \\
638 \\
639 \\
640\end{array}$ & $\begin{array}{l}20 \\
30 \\
20 \\
30 \\
20\end{array}$ & $\begin{array}{l}10 \\
15 \\
10 \\
15 \\
15\end{array}$ & $\begin{array}{r}100 \\
L \\
100 \\
L \\
L\end{array}$ & $\begin{array}{r}70 \\
100 \\
70 \\
70 \\
70\end{array}$ & $\begin{array}{l}30 \\
20 \\
15 \\
30 \\
30\end{array}$ & $\begin{array}{l}150 \\
300 \\
100 \\
200 \\
300\end{array}$ & $\begin{array}{l}3 \\
3 \\
8 \\
8 \\
8\end{array}$ & $\begin{array}{r}24-40-108 \\
18-40-107 \\
7-40-107 \\
7-40-107 \\
6-40-107\end{array}$ & $\begin{array}{c}\text { Jakeys Fork. } \\
\text { Do. } \\
\text { Do. } \\
\text { Do. } \\
\text { Do. }\end{array}$ \\
\hline
\end{tabular}


Semiquantitative spectrographic analyses

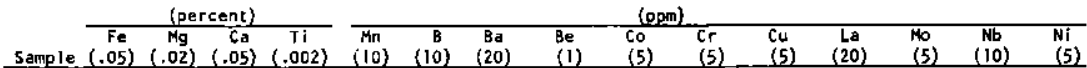

Organic sand samples--Cont inued

\begin{tabular}{|c|c|c|c|c|c|c|c|c|c|c|c|c|c|c|}
\hline $\begin{array}{l}656 \\
661 \\
662 \\
664 \\
668\end{array}$ & $\begin{array}{l}1.5 \\
3 \\
2 \\
2 \\
3\end{array}$ & $\begin{array}{r}0.7 \\
.7 \\
.3 \\
.7 \\
.7\end{array}$ & $\begin{array}{r}0.7 \\
1.5 \\
.7 \\
.5 \\
1.5\end{array}$ & $\begin{array}{l}0.3 \\
.3 \\
.15 \\
.2 \\
.5\end{array}$ & $\begin{array}{r}300 \\
300 \\
300 \\
1,000 \\
300\end{array}$ & $\begin{array}{c}10 \\
15 \\
10 \\
10 \\
2\end{array}$ & $\begin{array}{l}300 \\
150 \\
150 \\
150 \\
200\end{array}$ & $\begin{array}{l}1.5 \\
1 \\
1 \\
1 \\
1.5\end{array}$ & $\begin{array}{l}10 \\
15 \\
10 \\
10 \\
10\end{array}$ & $\begin{array}{r}70 \\
70 \\
70 \\
100 \\
70\end{array}$ & $\begin{array}{l}15 \\
20 \\
15 \\
15 \\
15\end{array}$ & $\begin{array}{l}70 \\
20 \\
70 \\
70 \\
70\end{array}$ & $\begin{array}{l}\mathrm{N} \\
\mathrm{N} \\
\mathrm{N} \\
\mathrm{L} \\
\mathrm{N}\end{array}$ & $\begin{array}{l}\mathrm{L} \\
\mathrm{L} \\
\mathrm{L} \\
\mathrm{L} \\
\mathrm{L}\end{array}$ \\
\hline $\begin{array}{l}670 \\
672 \\
685 \\
687 \\
689\end{array}$ & $\begin{array}{l}3 \\
3 \\
3 \\
5 \\
3\end{array}$ & $\begin{array}{l}2 \\
1 \\
1.5 \\
.7 \\
.5\end{array}$ & $\begin{array}{l}2 \\
1.5 \\
2 \\
1 \\
.7\end{array}$ & $\begin{array}{l}.5 \\
.5 \\
.3 \\
.3 \\
.3\end{array}$ & $\begin{array}{r}700 \\
1,000 \\
700 \\
500 \\
500\end{array}$ & $\begin{array}{c}L \\
L \\
10 \\
L \\
L\end{array}$ & $\begin{array}{l}300 \\
300 \\
300 \\
300 \\
300\end{array}$ & $\begin{array}{l}1.5 \\
1.5 \\
1 \\
1 \\
1\end{array}$ & $\begin{array}{l}15 \\
15 \\
10 \\
15 \\
15\end{array}$ & $\begin{array}{r}150 \\
70 \\
100 \\
150 \\
100\end{array}$ & $\begin{array}{l}10 \\
20 \\
10 \\
15 \\
15\end{array}$ & $\begin{array}{r}150 \\
70 \\
50 \\
30 \\
30\end{array}$ & $\begin{array}{l}N \\
N \\
N \\
N \\
N\end{array}$ & $\begin{array}{c}L \\
10 \\
L \\
L \\
L\end{array}$ \\
\hline $\begin{array}{l}691 \\
693 \\
695 \\
698 \\
699\end{array}$ & $\begin{array}{l}3 \\
5 \\
7 \\
5 \\
5\end{array}$ & $\begin{array}{l}.5 \\
.7 \\
!\end{array}$ & $\begin{array}{l}1 \\
1 \\
2 \\
1.5 \\
1.5\end{array}$ & $\begin{array}{l}.3 \\
.5 \\
.7 \\
.5 \\
.5\end{array}$ & $\begin{array}{r}500 \\
700 \\
700 \\
1,000 \\
700\end{array}$ & $\begin{array}{l}\mathrm{L} \\
N \\
N \\
L \\
N\end{array}$ & $\begin{array}{l}300 \\
300 \\
200 \\
300 \\
200\end{array}$ & $\begin{array}{l}1 \\
1 \\
L \\
1 \\
L\end{array}$ & $\begin{array}{l}15 \\
20 \\
30 \\
30 \\
30\end{array}$ & $\begin{array}{l}150 \\
200 \\
300 \\
200 \\
300\end{array}$ & $\begin{array}{l}10 \\
15 \\
15 \\
20 \\
15\end{array}$ & $\begin{array}{l}50 \\
70 \\
30 \\
20 \\
30\end{array}$ & $\begin{array}{l}\mathbf{N} \\
\mathbf{N} \\
\mathbf{N} \\
\mathbf{N} \\
\mathbf{N}\end{array}$ & $\begin{array}{l}\text { L } \\
L \\
L \\
\text { L } \\
L\end{array}$ \\
\hline $\begin{array}{l}700 \\
701 \\
702 \\
703 \\
704\end{array}$ & $\begin{array}{l}5 \\
3 \\
3 \\
3 \\
3\end{array}$ & $\begin{array}{r}1.5 \\
.3 \\
.3 \\
.3 \\
.3\end{array}$ & $\begin{array}{l}2 \\
.15 \\
.2 \\
.2 \\
.15\end{array}$ & $\begin{array}{l}.7 \\
.5 \\
.3 \\
.3 \\
.3\end{array}$ & $\begin{array}{r}1,000 \\
200 \\
200 \\
500 \\
1,000\end{array}$ & $\begin{array}{l}N \\
50 \\
30 \\
30 \\
30\end{array}$ & $\begin{array}{l}200 \\
700 \\
700 \\
300 \\
300\end{array}$ & $\begin{array}{l}L \\
2 \\
1.5 \\
1.5 \\
1.5\end{array}$ & $\begin{array}{l}30 \\
15 \\
10 \\
10 \\
15\end{array}$ & $\begin{array}{r}300 \\
50 \\
50 \\
50 \\
50\end{array}$ & $\begin{array}{l}15 \\
15 \\
15 \\
15 \\
15\end{array}$ & $\begin{array}{l}20 \\
50 \\
50 \\
30 \\
30\end{array}$ & $\begin{array}{l}\mathbf{N} \\
N \\
N \\
N \\
N\end{array}$ & $\begin{array}{l}L \\
L \\
L \\
L\end{array}$ \\
\hline $\begin{array}{l}708 \\
723 \\
726 \\
730 \\
731\end{array}$ & $\begin{array}{l}3 \\
3 \\
3 \\
2 \\
2\end{array}$ & $\begin{array}{l}.7 \\
.5 \\
.3 \\
.5 \\
.5\end{array}$ & $\begin{array}{r}.5 \\
.7 \\
.5 \\
.5\end{array}$ & $\begin{array}{r}.3 \\
.3 \\
.2 \\
.3 \\
.3\end{array}$ & $\begin{array}{l}700 \\
500 \\
700 \\
700 \\
200\end{array}$ & $\begin{array}{c}15 \\
L \\
N \\
10 \\
10\end{array}$ & $\begin{array}{l}500 \\
300 \\
300 \\
500 \\
700\end{array}$ & $\begin{array}{l}1 \\
1 \\
1 \\
1 \\
1.5\end{array}$ & $\begin{array}{l}7 \\
10 \\
10 \\
10 \\
10\end{array}$ & $\begin{array}{r}100 \\
50 \\
20 \\
70 \\
100\end{array}$ & $\begin{array}{r}20 \\
15 \\
7 \\
10 \\
7\end{array}$ & $\begin{array}{r}100 \\
20 \\
20 \\
20 \\
150\end{array}$ & $\begin{array}{l}\mathbf{N} \\
N \\
N \\
N \\
N\end{array}$ & $\begin{array}{l}L \\
L \\
L \\
L\end{array}$ \\
\hline $\begin{array}{l}738 \\
743 \\
749 \\
750 \\
751\end{array}$ & $\begin{array}{l}1 \\
3 \\
3 \\
2 \\
5\end{array}$ & $\begin{array}{l}2^{.3} \\
.7 \\
1.5\end{array}$ & $\begin{array}{r}.3 \\
.7 \\
.7 \\
.7 \\
1.5\end{array}$ & $\begin{array}{l}.07 \\
.2 \\
.3 \\
.3 \\
.3\end{array}$ & $\begin{array}{l}150 \\
500 \\
300 \\
200 \\
700\end{array}$ & $\begin{array}{l}\mathbf{L} \\
\mathbf{N} \\
\mathbf{N} \\
\mathbf{N} \\
\mathbf{N}\end{array}$ & $\begin{array}{l}100 \\
200 \\
200 \\
300 \\
300\end{array}$ & $\begin{array}{l}1 \\
1 \\
1 \\
1\end{array}$ & $\begin{array}{r}L \\
30 \\
15 \\
7 \\
30\end{array}$ & $\begin{array}{l}100 \\
700 \\
150 \\
200 \\
300\end{array}$ & $\begin{array}{r}15 \\
10 \\
15 \\
10 \\
5\end{array}$ & $\begin{array}{l}50 \\
30 \\
50 \\
50 \\
20\end{array}$ & $\begin{array}{l}\mathbf{N} \\
\mathbf{N} \\
\mathbf{N} \\
\mathbf{N} \\
\mathbf{N}\end{array}$ & $\begin{array}{l}N \\
\text { L } \\
\text { L } \\
\text { L } \\
\text { L }\end{array}$ \\
\hline $\begin{array}{l}752 \\
753 \\
754 \\
755 \\
756\end{array}$ & $\begin{array}{l}5 \\
3 \\
3 \\
2 \\
3\end{array}$ & $\begin{array}{r}1.5 \\
1.5 \\
.7 \\
.7 \\
1\end{array}$ & $\begin{array}{l}1.5 \\
.7 \\
.7 \\
.7\end{array}$ & $\begin{array}{r}1 \\
.3 \\
.3 \\
.3 \\
.3\end{array}$ & $\begin{array}{r}700 \\
500 \\
500 \\
200 \\
1,000\end{array}$ & $\begin{array}{c}\mathbf{N} \\
\mathbf{N} \\
\mathbf{N} \\
\mathbf{N} \\
10\end{array}$ & $\begin{array}{l}300 \\
300 \\
300 \\
300 \\
200\end{array}$ & $\begin{array}{l}1 \\
2 \\
1.5 \\
1.5\end{array}$ & $\begin{array}{l}20 \\
20 \\
20 \\
15 \\
20\end{array}$ & $\begin{array}{l}300 \\
200 \\
150 \\
150 \\
200\end{array}$ & $\begin{array}{r}5 \\
15 \\
15 \\
7 \\
15\end{array}$ & $\begin{array}{l}20 \\
50 \\
50 \\
50 \\
50\end{array}$ & $\begin{array}{l}\mathrm{N} \\
\mathrm{N} \\
\mathrm{N} \\
\mathrm{N} \\
\mathrm{N}\end{array}$ & $\begin{array}{r}10 \\
L \\
L \\
L \\
10\end{array}$ \\
\hline $\begin{array}{l}757 \\
760 \\
762 \\
7631 \\
774\end{array}$ & $\begin{array}{l}3 \\
1 \\
2 \\
3 \\
7\end{array}$ & $\begin{array}{c}1.5 \\
.15 \\
.5 \\
.7 \\
3^{.75}\end{array}$ & $\begin{array}{r}.7 \\
.3 \\
.7 \\
.5 \\
1.5\end{array}$ & $\begin{array}{l}.2 \\
.05 \\
.2 \\
.2 \\
.3\end{array}$ & $\begin{array}{r}1,000 \\
150 \\
300 \\
300 \\
700\end{array}$ & $\begin{array}{r}10 \\
L \\
L \\
10 \\
N\end{array}$ & $\begin{array}{l}150 \\
150 \\
150 \\
200 \\
300\end{array}$ & $\begin{array}{l}1 \\
\mathrm{~L} \\
1 \\
1.5 \\
\mathrm{~L}\end{array}$ & $\begin{array}{r}50 \\
\mathrm{~L} \\
7 \\
30 \\
20\end{array}$ & $\begin{array}{l}500 \\
100 \\
150 \\
300 \\
500\end{array}$ & $\begin{array}{r}20 \\
10 \\
5 \\
30 \\
50\end{array}$ & $\begin{array}{r}30 \\
4 \\
150 \\
50 \\
20\end{array}$ & $\begin{array}{l}\mathrm{N} \\
\mathrm{N} \\
\mathrm{N} \\
\mathrm{N} \\
\mathrm{N}\end{array}$ & $\begin{array}{l}L \\
N \\
L \\
L \\
L\end{array}$ \\
\hline $\begin{array}{l}777 \\
902 \\
905 \\
907 \\
909\end{array}$ & $\begin{array}{l}5 \\
3 \\
7 \\
3 \\
3\end{array}$ & $\begin{array}{l}1.5 \\
1.5 \\
1.5 \\
1.5 \\
1.5\end{array}$ & $\begin{array}{l}2 \\
1 \\
1 \\
1 \\
.7\end{array}$ & $\begin{array}{l}.3 \\
.3 \\
.3 \\
.3 \\
.3\end{array}$ & $\begin{array}{r}700 \\
500 \\
i, 000 \\
500 \\
300\end{array}$ & $\begin{array}{l}\mathbf{N} \\
\mathbf{N} \\
\mathbf{N} \\
\mathbf{N} \\
\mathbf{N}\end{array}$ & $\begin{array}{l}500 \\
300 \\
300 \\
300 \\
300\end{array}$ & $\begin{array}{l}1 \\
1 \\
1 \\
1 \\
1\end{array}$ & $\begin{array}{l}15 \\
30 \\
50 \\
30 \\
30\end{array}$ & $\begin{array}{r}70 \\
700 \\
3,000 \\
700 \\
300\end{array}$ & $\begin{array}{l}\mathrm{L} \\
20 \\
15 \\
15 \\
30\end{array}$ & $\begin{array}{r}100 \\
50 \\
70 \\
30 \\
30\end{array}$ & $\begin{array}{l}\mathbf{N} \\
\mathbf{N} \\
\mathbf{N} \\
\mathbf{N} \\
\mathbf{N}\end{array}$ & $\begin{array}{r}L \\
10 \\
L \\
L \\
L\end{array}$ \\
\hline $\begin{array}{l}911 \\
916 \\
918 \\
950 \\
952\end{array}$ & $\begin{array}{l}7 \\
3 \\
3 \\
5 \\
3\end{array}$ & $\begin{array}{l}2 \\
1 \\
1.5 \\
1.7\end{array}$ & $\begin{array}{l}2 \\
1.5 \\
1.5 \\
1.5 \\
1.5\end{array}$ & $\begin{array}{l}.5 \\
.3 \\
.3 \\
.3 \\
.7\end{array}$ & $\begin{array}{r}1,000 \\
500 \\
700 \\
700 \\
700\end{array}$ & $\begin{array}{l}N \\
N \\
N \\
N \\
N\end{array}$ & $\begin{array}{l}200 \\
200 \\
300 \\
300 \\
150\end{array}$ & $\begin{array}{l}1 \\
1 \\
1.5 \\
L \\
L\end{array}$ & $\begin{array}{l}70 \\
15 \\
15 \\
20 \\
15\end{array}$ & $\begin{array}{r}1,000 \\
200 \\
200 \\
200 \\
30\end{array}$ & $\begin{array}{l}20 \\
15 \\
15 \\
30 \\
L\end{array}$ & $\begin{array}{r}2 \\
20 \\
20 \\
50 \\
150\end{array}$ & $\begin{array}{l}\mathbf{N} \\
\mathbf{N} \\
\mathbf{N} \\
\mathbf{N} \\
\mathbf{N}\end{array}$ & $\begin{array}{c}L \\
L \\
L \\
10 \\
L\end{array}$ \\
\hline $\begin{array}{l}954 \\
956 \\
970 \\
976 \\
977\end{array}$ & $\begin{array}{l}7 \\
5 \\
7 \\
5 \\
3\end{array}$ & $\begin{array}{l}3 \\
2 \\
1.5 \\
1.7 \\
.7\end{array}$ & $\begin{array}{l}2 \\
2 \\
2 \\
2 \\
1.5\end{array}$ & $\begin{array}{l}.2 \\
.3 \\
.3 \\
.3 \\
.3\end{array}$ & $\begin{array}{l}700 \\
500 \\
700 \\
700 \\
300\end{array}$ & $\begin{array}{c}\mathbf{N} \\
\mathbf{N} \\
\mathbf{N} \\
\mathbf{N} \\
10\end{array}$ & $\begin{array}{l}300 \\
700 \\
200 \\
300 \\
500\end{array}$ & $\begin{array}{l}\mathrm{L} \\
\mathrm{L} \\
\mathbf{N} \\
\mathrm{L} \\
\mathrm{L}\end{array}$ & $\begin{array}{l}20 \\
15 \\
15 \\
15 \\
10\end{array}$ & $\begin{array}{r}500 \\
300 \\
200 \\
100 \\
70\end{array}$ & $\begin{array}{l}20 \\
15 \\
15 \\
20 \\
10\end{array}$ & $\begin{array}{r}30 \\
100 \\
L \\
100 \\
70\end{array}$ & $\begin{array}{l}\mathrm{N} \\
\mathrm{N} \\
\mathrm{N} \\
\mathrm{N} \\
\mathrm{N}\end{array}$ & $\begin{array}{l}L \\
L \\
L \\
L \\
L\end{array}$ \\
\hline $\begin{array}{r}980 \\
982 \\
992 \\
1005 \\
1015\end{array}$ & $\begin{array}{l}3 \\
3 \\
3 \\
7 \\
3\end{array}$ & $2_{1}^{1} .7$ & $\begin{array}{l}1.5 \\
2 \\
1.5 \\
1.5 \\
1.5\end{array}$ & $\begin{array}{l}.2 \\
.2 \\
.2 \\
.3 \\
.2\end{array}$ & $\begin{array}{l}300 \\
500 \\
300 \\
700 \\
300\end{array}$ & $\begin{array}{l}\mathbf{N} \\
\mathbf{N} \\
\mathbf{N} \\
\mathbf{N} \\
\mathbf{N}\end{array}$ & $\begin{array}{l}300 \\
300 \\
300 \\
200 \\
500\end{array}$ & $\begin{array}{l}L \\
L \\
N \\
L \\
L\end{array}$ & $\begin{array}{r}10 \\
15 \\
10 \\
20 \\
7\end{array}$ & $\begin{array}{r}100 \\
70 \\
50 \\
700 \\
30\end{array}$ & $\begin{array}{r}5 \\
30 \\
5 \\
50 \\
L\end{array}$ & $\begin{array}{l}\mathrm{L} \\
50 \\
70 \\
30 \\
30\end{array}$ & $\begin{array}{l}\mathbf{N} \\
\mathbf{N} \\
\mathbf{N} \\
\mathbf{N} \\
\mathbf{N}\end{array}$ & $\begin{array}{l}\mathrm{L} \\
\mathrm{L} \\
\mathrm{L} \\
\mathrm{L} \\
\mathrm{L}\end{array}$ \\
\hline
\end{tabular}


the Glacier Primitive Area, Fremont County-Continued

Semiquantitative spectrographic analyses--Cont inued

\begin{tabular}{|c|c|c|c|c|c|c|c|}
\hline \multirow[b]{2}{*}{ Sample } & \multicolumn{6}{|c|}{$(\mathrm{ppm})$} & \multirow{2}{*}{$\frac{\text { (epm) }}{\mathrm{C} \times \mathrm{HM}}$} \\
\hline & $\begin{array}{c}\mathrm{Pb} \\
(10)\end{array}$ & $\begin{array}{l}56 \\
(5)\end{array}$ & $\begin{array}{c}5 r \\
(100)\end{array}$ & $\begin{array}{c}v \\
(10)\end{array}$ & $\begin{array}{c}Y \\
(10)\end{array}$ & $\begin{array}{c}2 r \\
(10)\end{array}$ & \\
\hline
\end{tabular}

\begin{tabular}{|c|c|c|c|c|c|c|c|c|c|}
\hline $\begin{array}{l}656 \\
661 \\
662 \\
664 \\
668\end{array}$ & $\begin{array}{l}50 \\
20 \\
15 \\
30 \\
15\end{array}$ & $\begin{array}{r}10 \\
15 \\
7 \\
10 \\
10\end{array}$ & $\begin{array}{r}150 \\
100 \\
L \\
L \\
200\end{array}$ & $\begin{array}{l}30 \\
70 \\
70 \\
70 \\
50\end{array}$ & $\begin{array}{l}20 \\
15 \\
20 \\
20 \\
30\end{array}$ & $\begin{array}{r}200 \\
50 \\
100 \\
500 \\
500\end{array}$ & $\begin{array}{l}3 \\
5 \\
5 \\
5 \\
8\end{array}$ & $\begin{array}{r}22-40-107 \\
25-40-108 \\
25-40-108 \\
24-40-108 \\
5-40-108\end{array}$ & $\begin{array}{c}\text { Jakeys Fork. } \\
\text { Fish Cr. } \\
\text { Jakeys Fork, } \\
\text { Oo. } \\
\text { Fish Cr. }\end{array}$ \\
\hline $\begin{array}{l}670 \\
672 \\
685 \\
687 \\
689\end{array}$ & $\begin{array}{l}10 \\
15 \\
15 \\
15 \\
10\end{array}$ & $\begin{array}{l}15 \\
15 \\
10 \\
10 \\
10\end{array}$ & $\begin{array}{r}300 \\
150 \\
L \\
100 \\
L\end{array}$ & $\begin{array}{l}70 \\
70 \\
50 \\
70 \\
70\end{array}$ & $\begin{array}{l}30 \\
30 \\
30 \\
20 \\
20\end{array}$ & $\begin{array}{l}300 \\
500 \\
300 \\
300 \\
200\end{array}$ & $\begin{array}{r}1 \\
10 \\
1 \\
N \\
3\end{array}$ & $\begin{array}{r}30-41-108 \\
31-41-108 \\
7-41-107 \\
13-41-108 \\
13-41-108\end{array}$ & $\begin{array}{c}\text { Warm Spg Cr. } \\
\text { Do. } \\
\text { Geyser Cr. } \\
\text { Do. } \\
D_{0} .\end{array}$ \\
\hline $\begin{array}{l}691 \\
693 \\
695 \\
698 \\
699\end{array}$ & $\begin{array}{l}10 \\
15 \\
15 \\
10 \\
15\end{array}$ & $\begin{array}{l}10 \\
15 \\
20 \\
20 \\
15\end{array}$ & $\begin{array}{l}200 \\
150 \\
150 \\
150 \\
100\end{array}$ & $\begin{array}{l}70 \\
100 \\
150 \\
100 \\
100\end{array}$ & $\begin{array}{l}20 \\
20 \\
30 \\
30 \\
30\end{array}$ & $\begin{array}{l}200 \\
200 \\
300 \\
500 \\
150\end{array}$ & $\begin{array}{l}3 \\
1 \\
5 \\
3 \\
1\end{array}$ & $\begin{array}{l}13-41-108 \\
24-41-108 \\
13-38-106 \\
24-38-106 \\
19-38-105\end{array}$ & $\begin{array}{l}\text { Geyser Cr. } \\
\text { Little Warm Spg Cr. } \\
\text { Dry Cr. } \\
\text { Do. } \\
\text { Do. }\end{array}$ \\
\hline $\begin{array}{l}700 \\
701 \\
702 \\
703 \\
704\end{array}$ & $\begin{array}{l}10 \\
15 \\
15 \\
10 \\
15\end{array}$ & $\begin{array}{l}20 \\
10 \\
10 \\
10 \\
10\end{array}$ & $\begin{array}{r}150 \\
100 \\
L \\
L \\
N\end{array}$ & $\begin{array}{r}100 \\
30 \\
50 \\
70 \\
70\end{array}$ & $\begin{array}{l}30 \\
50 \\
30 \\
30 \\
30\end{array}$ & $\begin{array}{r}70 \\
700 \\
500 \\
500 \\
300\end{array}$ & $\begin{array}{l}3 \\
3 \\
3 \\
1 \\
1\end{array}$ & $\begin{array}{l}19-38-105 \\
27-41-107 \\
23-41-107 \\
23-41-107 \\
26-41-108\end{array}$ & $\begin{array}{l}\text { Do. } \\
\text { Limekiln Gulch. } \\
\text { Do. } \\
\text { Do. } \\
\text { Little Warm Spg Cr. }\end{array}$ \\
\hline $\begin{array}{l}708 \\
723 \\
726 \\
730 \\
731\end{array}$ & $\begin{array}{l}20 \\
10 \\
10 \\
15 \\
15\end{array}$ & $\begin{array}{r}10 \\
7 \\
7 \\
7 \\
7\end{array}$ & $\begin{array}{l}100 \\
100 \\
200 \\
150 \\
150\end{array}$ & $\begin{array}{l}70 \\
50 \\
30 \\
50 \\
30\end{array}$ & $\begin{array}{l}10 \\
15 \\
10 \\
15 \\
30\end{array}$ & $\begin{array}{r}150 \\
1,000 \\
100 \\
200 \\
1,000\end{array}$ & $\begin{array}{l}1 \\
1 \\
3 \\
3 \\
1\end{array}$ & $\begin{array}{l}23-41-108 \\
21-41-108 \\
21-41-108 \\
21-41-108 \\
14-41-108\end{array}$ & $\begin{array}{l}\text { Warm Spg Cr. } \\
\text { Wildcat Cr. } \\
\text { Do. } \\
\text { Do. } \\
\text { Little Warm Spg Cr. }\end{array}$ \\
\hline $\begin{array}{l}738 \\
743 \\
749 \\
750 \\
751\end{array}$ & $\begin{array}{l}30 \\
30 \\
10 \\
10 \\
15\end{array}$ & $\begin{array}{l}1 \\
7 \\
15 \\
10 \\
15\end{array}$ & $\begin{array}{r}N \\
N \\
100 \\
100 \\
100\end{array}$ & $\begin{array}{r}30 \\
50 \\
70 \\
70 \\
100\end{array}$ & $\begin{array}{l}15 \\
15 \\
15 \\
20 \\
15\end{array}$ & $\begin{array}{r}50 \\
30 \\
300 \\
150 \\
200\end{array}$ & $\begin{array}{l}1 \\
1 \\
3 \\
1 \\
1\end{array}$ & $\begin{array}{r}3-37-106 \\
2-37-106 \\
29-38-105 \\
20-38-105 \\
21-38-105\end{array}$ & $\begin{array}{l}\text { Dry Cr. } \\
\text { Do. } \\
\text { Do. } \\
\text { Do. } \\
\text { Do. }\end{array}$ \\
\hline $\begin{array}{l}752 \\
753 \\
754 \\
755 \\
756\end{array}$ & $\begin{array}{l}10 \\
15 \\
15 \\
10 \\
30\end{array}$ & $\begin{array}{l}20 \\
15 \\
15 \\
10 \\
15\end{array}$ & $\begin{array}{r}150 \\
100 \\
100 \\
1 \\
100\end{array}$ & $\begin{array}{r}100 \\
70 \\
70 \\
70 \\
70\end{array}$ & $\begin{array}{l}30 \\
20 \\
15 \\
15 \\
20\end{array}$ & $\begin{array}{l}700 \\
150 \\
300 \\
200 \\
300\end{array}$ & $\begin{array}{l}8 \\
3 \\
5 \\
3 \\
3\end{array}$ & $\begin{array}{l}21-38-105 \\
21-38-105 \\
10-3-6 \\
10-3-6 \\
26-38-106\end{array}$ & $\begin{array}{l}\text { Do. } \\
\text { Do. } \\
\text { Do. } \\
\text { Do. } \\
\text { Do. }\end{array}$ \\
\hline $\begin{array}{l}757 \\
760 \\
762 \\
763 \\
774\end{array}$ & $\begin{array}{r}70 \\
10 \\
\mathrm{~L} \\
70 \\
30\end{array}$ & $\begin{array}{r}10 \\
\mathrm{~L} \\
10 \\
15 \\
15\end{array}$ & $\begin{array}{c}N \\
\text { L } \\
L \\
100\end{array}$ & $\begin{array}{r}70 \\
30 \\
50 \\
70 \\
150\end{array}$ & $\begin{array}{l}20 \\
10 \\
20 \\
20 \\
10\end{array}$ & $\begin{array}{r}70 \\
70 \\
300 \\
70 \\
50\end{array}$ & $\begin{array}{l}1 \\
1 \\
1 \\
5 \\
1\end{array}$ & $\begin{array}{c}26-38-106 \\
3-3-6 \\
16-38-105 \\
7-37-105 \\
30-37-105\end{array}$ & $\begin{array}{l}\text { Do. } \\
\text { Do. } \\
\text { Do. } \\
\text { Do. } \\
\text { Bull Lake Cr. }\end{array}$ \\
\hline $\begin{array}{l}777 \\
902 \\
905 \\
907 \\
909\end{array}$ & $\begin{array}{l}15 \\
20 \\
10 \\
10 \\
15\end{array}$ & $\begin{array}{l}15 \\
20 \\
20 \\
15 \\
10\end{array}$ & $\begin{array}{r}150 \\
150 \\
L \\
L \\
N\end{array}$ & $\begin{array}{l}70 \\
70 \\
70 \\
70 \\
70\end{array}$ & $\begin{array}{r}700 \\
20 \\
20 \\
15 \\
15\end{array}$ & $\begin{array}{l}100 \\
300 \\
500 \\
150 \\
150\end{array}$ & $\begin{array}{l}1 \\
3 \\
3 \\
8 \\
3\end{array}$ & $\begin{array}{r}13-40-108 \\
12-37-106 \\
6-37-105 \\
30-38-105 \\
35-38-106\end{array}$ & $\begin{array}{c}\text { Jakeys Fork. } \\
\text { Dry Cr. } \\
\text { Do. } \\
\text { Do. } \\
\text { Do. }\end{array}$ \\
\hline $\begin{array}{l}911 \\
916 \\
918 \\
950 \\
952\end{array}$ & $\begin{array}{l}10 \\
L \\
10 \\
20 \\
15\end{array}$ & $\begin{array}{l}30 \\
15 \\
10 \\
15 \\
15\end{array}$ & $\begin{array}{r}\mathrm{N} \\
\mathrm{L} \\
100 \\
\mathrm{~L} \\
\mathrm{~L}\end{array}$ & $\begin{array}{r}100 \\
70 \\
70 \\
100 \\
50\end{array}$ & $\begin{array}{r}30 \\
15 \\
15 \\
30 \\
>200\end{array}$ & $\begin{array}{r}50 \\
300 \\
200 \\
70 \\
700\end{array}$ & $\begin{array}{l}3 \\
3 \\
1 \\
3 \\
3\end{array}$ & $\begin{array}{l}26-38-106 \\
30-38-105 \\
31-38-105 \\
19-38-105 \\
22-39-106\end{array}$ & $\begin{array}{l}\text { Do. } \\
\text { Do. } \\
\text { Do. } \\
\text { Do. } \\
\text { Dinwoody Cr. }\end{array}$ \\
\hline $\begin{array}{l}954 \\
956 \\
970 \\
976 \\
977\end{array}$ & $\begin{array}{l}20 \\
20 \\
20 \\
30 \\
20\end{array}$ & $\begin{array}{l}15 \\
15 \\
15 \\
15 \\
10\end{array}$ & $\begin{array}{l}100 \\
300 \\
100 \\
200 \\
200\end{array}$ & $\begin{array}{r}70 \\
70 \\
100 \\
100 \\
70\end{array}$ & $\begin{array}{l}20 \\
30 \\
20 \\
30 \\
30\end{array}$ & $\begin{array}{r}70 \\
150 \\
30 \\
150 \\
150\end{array}$ & $\begin{array}{l}3 \\
5 \\
3 \\
3 \\
5\end{array}$ & $\begin{array}{l}15-37-106 \\
23-37-106 \\
22-36-106 \\
22-36-106 \\
22-36-106\end{array}$ & $\begin{array}{l}\text { Dry Cr. } \\
\text { Bull Lake Cr. } \\
\text { Do. } \\
\text { Do. } \\
\text { Do. }\end{array}$ \\
\hline $\begin{array}{r}980 \\
982 \\
992 \\
1005 \\
1015\end{array}$ & $\begin{array}{l}20 \\
15 \\
20 \\
30 \\
15\end{array}$ & $\begin{array}{l}7 \\
10 \\
10 \\
15 \\
15\end{array}$ & $\begin{array}{r}200 \\
200 \\
100 \\
L \\
300\end{array}$ & $\begin{array}{r}50 \\
70 \\
50 \\
100 \\
50\end{array}$ & $\begin{array}{l}10 \\
20 \\
15 \\
15 \\
20\end{array}$ & $\begin{array}{r}50 \\
150 \\
100 \\
100 \\
70\end{array}$ & $\begin{array}{l}1 \\
5 \\
3 \\
3 \\
3\end{array}$ & $\begin{array}{l}23-36-106 \\
15-1-6 \\
4-35-106 \\
29-37-105 \\
16-36-106\end{array}$ & $\begin{array}{l}\text { Do. } \\
\text { Do. } \\
\text { Do. } \\
\text { Do. } \\
\text { Do. }\end{array}$ \\
\hline
\end{tabular}


TABLE 10.-Analyses of stream-sediment and soil samples from

Semiquantitative spectrographic analyses

\begin{tabular}{|c|c|c|c|c|c|c|c|c|c|c|c|c|c|c|}
\hline \multirow[b]{2}{*}{ Sample } & \multicolumn{3}{|c|}{ (percent) } & \multicolumn{8}{|c|}{ (pPm) } & & & \\
\hline & $\begin{array}{cc}\mathrm{Fe} & \mathrm{Mg} \\
(.05) & (.02)\end{array}$ & $\begin{array}{c}\mathrm{Ca} \\
(.05)\end{array}$ & $\begin{array}{c}\overline{T i} \\
(.002)\end{array}$ & $\begin{array}{l}\mathrm{Mn} \\
(10)\end{array}$ & $\begin{array}{c}\mathrm{B} \\
(10)\end{array}$ & $\begin{array}{c}6 a \\
(20)\end{array}$ & $\begin{array}{l}\mathrm{Be} \\
\text { (1) }\end{array}$ & $\begin{array}{l}\text { Co } \\
\text { (5) }\end{array}$ & $\begin{array}{l}\mathrm{Cr} \\
(5)\end{array}$ & Cu & $\begin{array}{c}\text { La } \\
(20)\end{array}$ & (5) & $\begin{array}{c}\text { Nb } \\
(10)\end{array}$ & $\begin{array}{l}\mathrm{N1} \\
(5)\end{array}$ \\
\hline
\end{tabular}

Organic sand samples--Cont inued

\begin{tabular}{|c|c|c|c|c|c|c|c|c|c|c|c|c|c|c|c|}
\hline $\begin{array}{l}1017 \\
1018 \\
1019 \\
1034 \\
1071\end{array}$ & $\begin{array}{l}5 \\
3 \\
7 \\
5 \\
2\end{array}$ & $\begin{array}{l}1.5 \\
1 \\
2 \\
1.5 \\
1\end{array}$ & $\begin{array}{l}2 \\
2 \\
1.5 \\
1.5 \\
1\end{array}$ & $\begin{array}{l}.3 \\
.3 \\
.3 \\
.3 \\
.2\end{array}$ & $\begin{array}{r}700 \\
700 \\
700 \\
1,000 \\
300\end{array}$ & $\begin{array}{l}N \\
N \\
N \\
L \\
L\end{array}$ & $\begin{array}{l}300 \\
300 \\
500 \\
300 \\
300\end{array}$ & $\begin{array}{l}\mathrm{L} \\
\mathrm{L} \\
\mathrm{L} \\
\mathrm{L} \\
\mathbf{l}\end{array}$ & $\begin{array}{l}15 \\
10 \\
15 \\
15 \\
10\end{array}$ & $\begin{array}{r}300 \\
150 \\
300 \\
100 \\
70\end{array}$ & $\begin{array}{r}15 \\
10 \\
10 \\
20 \\
7\end{array}$ & $\begin{array}{r}50 \\
30 \\
30 \\
70 \\
100\end{array}$ & $\begin{array}{l}\mathbf{N} \\
\mathbf{N} \\
\mathrm{N} \\
\mathbf{N} \\
\mathbf{N}\end{array}$ & $\begin{array}{l}\mathrm{L} \\
\mathbf{L} \\
\mathbf{L} \\
\mathrm{L} \\
\mathrm{L}\end{array}$ & $\begin{array}{r}100 \\
30 \\
70 \\
30 \\
30\end{array}$ \\
\hline $\begin{array}{l}1074 \\
1087\end{array}$ & $\begin{array}{l}3 \\
2\end{array}$ & $\begin{array}{r}1.5 \\
.7\end{array}$ & $\begin{array}{l}1.5 \\
1.5\end{array}$ & .3 & $\begin{array}{l}700 \\
300\end{array}$ & $\mathrm{~L}$ & $\begin{array}{l}500 \\
300\end{array}$ & $\begin{array}{l}\mathrm{L} \\
\mathbf{L}\end{array}$ & $\begin{array}{r}15 \\
7\end{array}$ & $\begin{array}{r}100 \\
50\end{array}$ & $\begin{array}{r}10 \\
\mathrm{~L}\end{array}$ & $\begin{array}{l}70 \\
70\end{array}$ & $\stackrel{N}{N}$ & $\mathrm{~L}$ & $\begin{array}{l}50 \\
15\end{array}$ \\
\hline
\end{tabular}


the Glacier Primitive Area, Fremont County-Continued

Semiquantitative spectrographic analyses--Continued

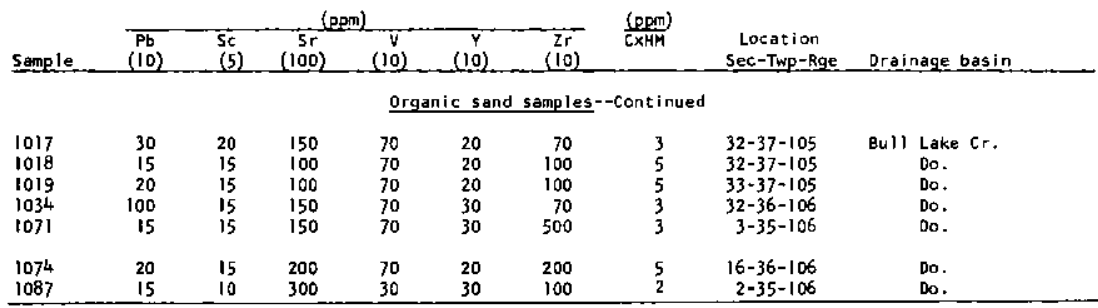




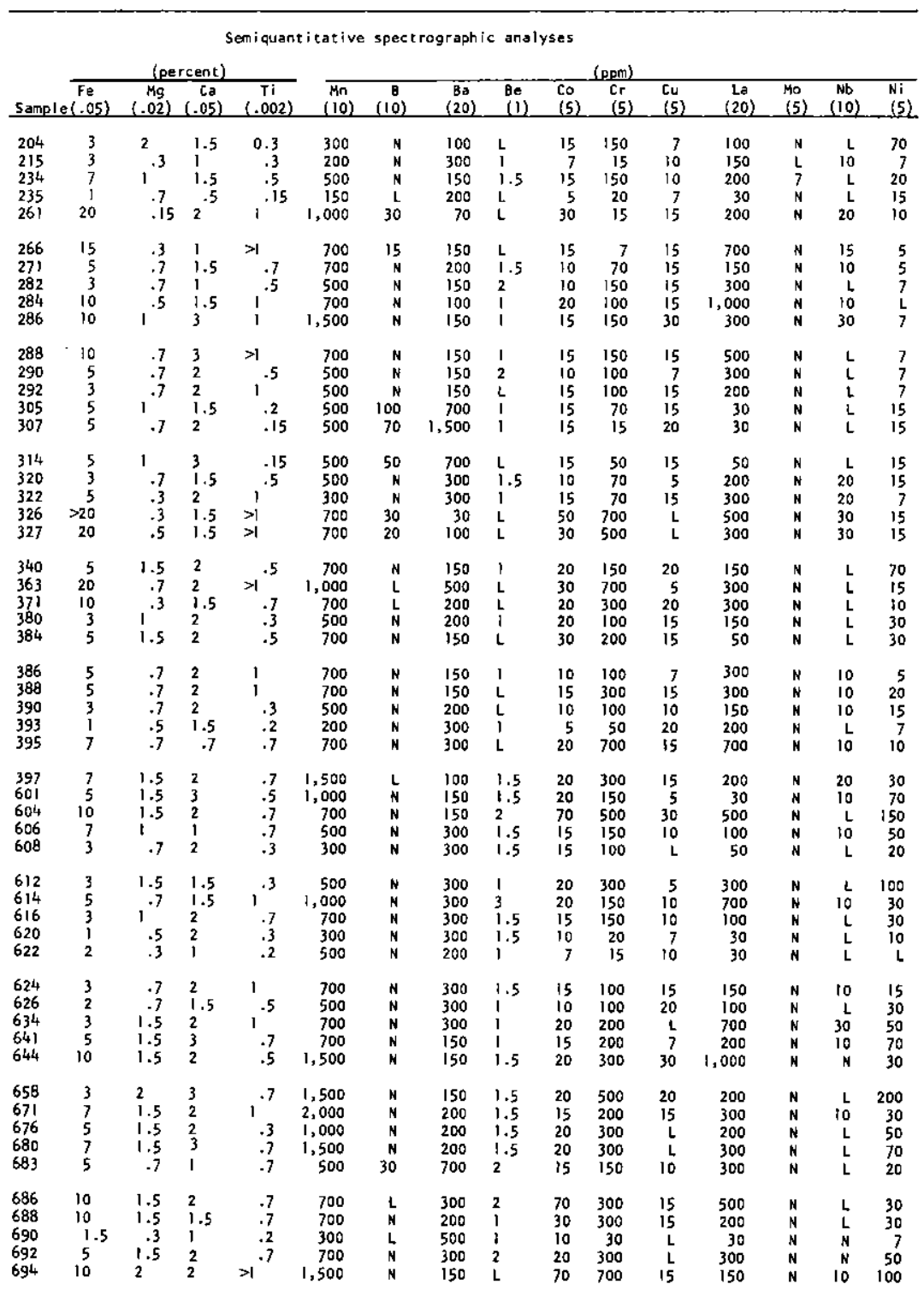


samples from the Glacier Primitive Area, Fremont County

A. W. Wells, M. S. Rickard, and J. G. Frisken]

\begin{tabular}{|c|c|c|c|c|c|c|c|c|c|}
\hline \multirow[b]{2}{*}{ Sample } & \multicolumn{6}{|c|}{$\begin{array}{l}\text { Semi quant i tat ive spect rograph ic } \\
\text { analyses --Cont inued } \\
\text { (ppm) }\end{array}$} & \multirow{2}{*}{$\begin{array}{c}\begin{array}{c}\text { Atomic } \\
\text { Absorpt ion } \\
\text { (ppm) }\end{array} \\
A u\end{array}$} & \multirow[b]{2}{*}{$\begin{array}{c}\text { Location } \\
\text { Sec-Twp-Rge }\end{array}$} & \multirow[b]{2}{*}{ Drainage basin } \\
\hline & $\begin{array}{l}\mathrm{pb} \\
(10)\end{array}$ & $\begin{array}{l}\text { Sc } \\
\text { (5) }\end{array}$ & $\begin{array}{c}\overline{s r} \\
(100)\end{array}$ & $\begin{array}{c}V \\
(10)\end{array}$ & $\begin{array}{c}y \\
(10) \\
\end{array}$ & $\begin{array}{l}\mathrm{Zr} \\
010\rangle \\
\end{array}$ & & & \\
\hline 204 & 10 & 15 & 150 & 30 & 30 & 150 & $\cdots$ & $11-38-107$ & Dimwoody $\mathrm{Cr}$. \\
\hline 215 & 30 & 7 & 150 & 30 & 70 & 500 & -- & $17-38-106$ & Do.' \\
\hline 234 & 50 & 30 & 150 & 70 & 200 & 700 & $\cdots$ & $14-39-107$ & Torrey Cr. \\
\hline 235 & 20 & 5 & $L$ & 15 & 15 & 100 & -- & $13-39-107$ & Do. \\
\hline 261 & 15 & 20 & 200 & 200 & 200 & $>1,000$ & -- & $35-38-107$ & Dirnwoody $\mathrm{Cr}$. \\
\hline 266 & 70 & 15 & L & 100 & $>200$ & 1,000 & --- & $29-38-106$ & Do. \\
\hline 271 & 15 & 15 & 100 & 70 & 150 & 1,000 & $\cdots$ & $39-38-106$ & Do. \\
\hline 282 & 30 & 15 & 100 & 50 & 100 & 1,000 & $\cdots$ & $21-39-105$ & Do. \\
\hline 284 & 100 & 15 & 300 & 100 & 200 & 1,000 & $\cdots$ & $11-38-106$ & Do. \\
\hline 286 & 70 & 15 & 200 & 100 & $>200$ & $>1,000$ & -- & $2-38-106$ & Do. \\
\hline 288 & 50 & 20 & 300 & 100 & 200 & $>1,000$ & -- & $2-38-106$ & Do. \\
\hline 290 & 15 & 15 & 300 & 70 & 150 & 1,000 & -- & $35-39-106$ & Do. \\
\hline 292 & 30 & 15 & 200 & 70 & $>200$ & 1,000 & $\cdots$ & $26-39-106$ & Do. \\
\hline 305 & 15 & 7 & N & 30 & 30 & 700 & -- & $7-40-106$ & Torrey $\mathrm{cr}$. \\
\hline 307 & 15 & 5 & N & 15 & 20 & 150 & -- & $7-40-106$ & Do. \\
\hline 314 & 10 & 5 & L & 20 & 20 & 300 & -- & $33-41-106$ & Do. \\
\hline 320 & 50 & 15 & 200 & 30 & 100 & 1,000 & --- & $8-38-106$ & Di nwoody $\mathrm{Cr}$. \\
\hline 322 & 30 & 15 & 500 & 70 & $>200$ & 700 & $\cdots$ & $8-38-106$ & Do. \\
\hline 326 & 20 & 70 & L & 150 & $>200$ & $>1,000$ & $\cdots$ & $6-37-106$ & Do. \\
\hline 327 & 20 & 50 & $\mathbf{L}$ & 100 & $>200$ & $>1,000$ & --- & $5-37-106$ & Do. \\
\hline 340 & 20 & 20 & 200 & 70 & 150 & 150 & -- & $28-39-106$ & Do. \\
\hline 363 & 30 & 100 & $\mathbf{N}$ & 70 & $>200$ & $>1,000$ & $\cdots$ & $15-38-106$ & Do. \\
\hline 371 & 30 & 15 & 150 & 100 & 200 & $>1,000$ & -- & $1-37-107$ & D. \\
\hline 380 & 15 & 15 & 150 & 50 & 50 & 200 & --- & $23-39-107$ & Torrey $\mathrm{Cr}$ \\
\hline 384 & 15 & 15 & 100 & 100 & 70 & 500 & $\cdots$ & $27-39-106$ & Dinwoody $\mathrm{Cr}$. \\
\hline 386 & 20 & 15 & 300 & 70 & 200 & 700 & -- & $26-39-106$ & Do. \\
\hline 388 & 50 & 20 & 300 & 100 & $>200$ & 1,000 & -- & $26-39-106$ & Do. \\
\hline 390 & 20 & 15 & 300 & 70 & 100 & 500 & -- & $24-39-106$ & Do. \\
\hline 393 & 15 & 7 & 200 & 20 & 30 & 150 & $\cdots$ & $10-4-6$ & Do. \\
\hline 395 & 70 & 15 & $N$ & 100 & $>200$ & 500 & -- & $33-41-107$ & Jakeys Fork. \\
\hline 397 & 50 & 50 & 100 & 150 & $>200$ & $>1,000$ & 0.10 & $3-39-107$ & Torrey Cr. \\
\hline 601 & 10 & 30 & 100 & 150 & 150 & 300 & $<.04$ & $35-40-107$ & \\
\hline 604 & 30 & 70 & L & 200 & $>200$ & 1,000 & $<.02$ & $29-40-107$ & Jakeys Fork. \\
\hline 606 & 20 & 15 & 100 & 100 & 50 & 700 & $<.04$ & $25-41-107$ & Do. \\
\hline 608 & 10 & 10 & 300 & 50 & 30 & 700 & $<.02$ & $31-41-107$ & Do. \\
\hline 612 & 15 & 15 & 150 & 70 & 30 & 500 & $<.02$ & $34-41-108$ & Warm Spg Cr. \\
\hline 614 & 30 & 30 & 200 & 100 & 100 & $>1,000$ & $<.02$ & $27-41-108$ & Do. \\
\hline 616 & 15 & 15 & 300 & 70 & 30 & 700 & $<.02$ & $27-41-108$ & Do. \\
\hline 620 & 15 & 7 & 300 & 70 & 15 & 300 & $<.02$ & $28-41-108$ & Do. \\
\hline 622 & 10 & 7 & 100 & 30 & 15 & 700 & -- & $28-41-108$ & Do. \\
\hline 624 & 10 & 20 & 300 & 100 & 50 & $>1,000$ & $<.02$ & $29-41-108$ & Do. \\
\hline 626 & 10 & 15 & 200 & 50 & 20 & 700 & $<.02$ & $29-41-108$ & \\
\hline 634 & 30 & 20 & L & 100 & 200 & 700 & $<.04$ & $24-40-108$ & Jakeys fork. \\
\hline 641 & 20 & 20 & 100 & 100 & 150 & 500 & $<.02$ & $6-40-107$ & Do. \\
\hline 644 & 100 & 30 & 100 & 150 & 100 & 1,000 & $<.04$ & $26-41-108$ & Little Warm Spg Cr. \\
\hline & 20 & 30 & 100 & & $>200$ & 700 & $<.02$ & $14-40-107$ & Jakeys Fork. \\
\hline 671 & 20 & 30 & 300 & 70 & 100 & 1,000 & $<.04$ & $30-41-108$ & Warm Spg $\mathrm{Cr}$. \\
\hline 676 & 15 & 30 & 150 & 150 & 50 & 700 & $<.02$ & $19-41-107$ & Little Warm Spg Cr. \\
\hline 680 & 20 & 30 & 150 & 100 & 100 & 1,000 & $<.04$ & $20-47-107$ & Do. \\
\hline 683 & 30 & 15 & 100 & 100 & 150 & $>1,000$ & $<.05$ & $16-41-107$ & Do. \\
\hline 686 & 30 & 30 & N & 150 & 70 & $>1,000$ & .08 & $7-4 i-107$ & Geyser Cr. \\
\hline 688 & 15 & 70 & N & 100 & 100 & $>1,000$ & .08 & $13-4 \mid-108$ & Do. \\
\hline 690 & 10 & 7 & 100 & 30 & 10 & 700 & .20 & $13-41=108$ & Do. \\
\hline 692 & 10 & 30 & 300 & 100 & 70 & $>1,000$ & .08 & $13-41-108$ & Do. \\
\hline 694 & $L$ & 50 & L & 150 & 100 & 700 & .04 & $19-38-105$ & Dry Cr. \\
\hline
\end{tabular}




\begin{tabular}{|c|c|c|c|c|c|c|c|c|c|c|c|c|c|c|c|}
\hline \multirow[b]{3}{*}{ 玍 } & \multicolumn{15}{|c|}{ Semiquantitative spectrographic analyses } \\
\hline & \multicolumn{4}{|c|}{ (percent) } & \multicolumn{11}{|c|}{$(\mathrm{ppm})$} \\
\hline & $\begin{array}{l}\mathrm{Fe} \\
.05) \\
\end{array}$ & $\begin{array}{c}\mathrm{Mg} \\
(.02) \\
\end{array}$ & $\begin{array}{c}C a \\
(.05)\end{array}$ & $\begin{array}{c}T i \\
(.002) \\
\end{array}$ & $\begin{array}{c}M n \\
(10)\end{array}$ & $\begin{array}{c}8 \\
(10) \\
\end{array}$ & $\begin{array}{c}\theta a \\
(20) \\
\end{array}$ & $\begin{array}{l}\mathrm{Be} \\
\text { (I) }\end{array}$ & $\begin{array}{l}\text { Co } \\
(5)\end{array}$ & $\begin{array}{l}c r \\
\text { (5) }\end{array}$ & $\begin{array}{l}\mathrm{Cu} \\
\text { (5) }\end{array}$ & $\begin{array}{c}\mathrm{La} \\
(20)\end{array}$ & $\begin{array}{l}\text { Mo } \\
(5)\end{array}$ & $\begin{array}{c}\mathrm{Nb} \\
(10) \\
\end{array}$ & $\begin{array}{l}\mathrm{Ni} \\
(5)\end{array}$ \\
\hline 696 & 7 & 2 & 2 & 1 & 1,000 & N & 150 & 1 & 50 & 500 & 7 & 100 & $\mathrm{~N}$ & $L$ & 150 \\
\hline 710 & 7 & 1.5 & 1.5 & $>1$ & 1,000 & N & 500 & 1 & 20 & 700 & L & 700 & N & 10 & 70 \\
\hline 714 & 7 & 1.5 & .7 & .7 & 700 & N & 200 & 1 & so & 300 & 20 & 300 & N & 10 & 50 \\
\hline 718 & 5 & 1.5 & 1 & .5 & 300 & N & 300 & 1 & 20 & 200 & L & 150 & N & L & 70 \\
\hline 722 & 15 & .7 & .5 & $>1$ & 1,000 & L. & 150 & 1 & 701 & 1,000 & L & $>1,000$ & $\mathrm{~N}$ & 10 & 30 \\
\hline 725 & 15 & .5 & .5 & $>1$ & 1,000 & L & 150 & 1 & 70 & 300 & 10 & 700 & N & 10 & 20 \\
\hline 727 & 3 & .7 & 1.5 & .5 & 700 & $\mathbf{N}$ & 300 & 1 & 15 & 70 & N & 100 & N & $\mathrm{L}$ & 20 \\
\hline 729 & 7 & .7 & .5 & 1 & 1,500 & 20 & 300 & 1 & 15 & 300 & N & 1,000 & N & 20 & 10 \\
\hline 736 & 7 & 5 & 3 & 1 & 1,500 & N & 100 & 1 & 1002 & 2,000 & 7 & 50 & N & 20 & 300 \\
\hline 742 & 7 & 3 & 2 & $>1$ & 1,500 & N & 70 & $i$ & 100 & 1,000 & 5 & 150 & N & 20 & 150 \\
\hline 748 & 3 & 1.5 & 1.5 & .7 & 1,500 & N & 100 & 1 & 201 & 1,000 & L & 100 & N & 30 & 100 \\
\hline 7611 & 7 & 1.5 & 1.5 & $>1$ & 1,500 & $N$ & 200 & $\mathrm{~L}$ & 30 & 300 & 5 & 500 & 30 & $\mathrm{~L}$ & 50 \\
\hline 766 If & 5 & .3 & .7 & .2 & 200 & 15 & $\Varangle, 000$ & 1 & 10 & 30 & 10 & 70 & $\mathrm{~N}$ & $\mathrm{~L}$ & 20 \\
\hline 771 & 7 & 3 & 3 & .5 & 1,500 & N & 150 & 1 & 15 & 500 & L & 100 & N & $L$ & 100 \\
\hline 775 & 7 & & 2 & .7 & 1,500 & N & 150 & $\mathbf{L}$ & 15 & 700 & L & L & N & $\mathbf{L}$ & 150 \\
\hline 778 & 7 & 1.5 & 2 & .5 & 700 & N & 300 & N & 15 & 150 & 10 & 300 & N & 10 & 50 \\
\hline 780 & 7 & 1.5 & 3 & .5 & 1,000 & N & 200 & L & 151 & 1,000 & 10 & 200 & N & L & 100 \\
\hline 784 & 3 & .7 & 1.5 & .3 & 300 & N & 200 & L & 10 & 70 & $L$ & 70 & N & 15 & 20 \\
\hline 786 & 3 & .5 & 1.5 & .3 & 200 & N & 200 & N & 5 & 30 & 5 & 100 & N & $\mathrm{L}$ & 15 \\
\hline 789 & 15 & 1 & 5 & .5 & 500 & $\mathbf{N}$ & 150 & L & 15 & 300 & 10 & 100 & N & 10 & 20 \\
\hline 791 & 15 & 1 & 1.5 & .5 & 700 & N & 150 & 1 & 15 & 100 & 5 & 50 & N & 15 & 15 \\
\hline 799 & 3 & 1 & 2 & .2 & 500 & N & 300 & L & 15 & 150 & 5 & 30 & $\mathrm{~N}$ & L & 30 \\
\hline 910 & 7 & 5 & 3 & .5 & 1,000 & N & 100 & 1 & 70 & 1,000 & 15 & 30 & N & L & 200 \\
\hline 915 & 5 & 1.5 & 1.5 & .7 & 700 & N & 200 & 1 & 20 & 500 & $L$ & 30 & N & 10 & 100 \\
\hline 917 & 7 & 1.5 & 1.5 & $>1$ & 1,500 & $\mathrm{~N}$ & 100 & 1 & 30 & 500 & 5 & 300 & N & 20 & 100 \\
\hline 920 & 7 & 1.5 & 2 & .5 & 1,500 & N & 100 & 1 & 30 & 500 & L & 100 & N & 10 & 150 \\
\hline 923 & 5 & .7 & .5 & .3 & 300 & $N$ & 300 & 1.5 & 10 & 150 & 15 & 150 & N & L & 30 \\
\hline 926 & 7 & 3 & 5 & .5 & 1,000 & N & 300 & $L$ & 151 & 1,500 & L & 150 & N & $\mathrm{L}$ & 100 \\
\hline 928 & 5 & 1.5 & 3 & .5 & 700 & N & 300 & L & 15 & 300 & 7 & 50 & N & $\mathrm{L}$ & 30 \\
\hline 932 & 20 & 1 & 3 & 1 & 1,000 & $\mathrm{~N}$ & 20 & L & 30 & 300 & 15 & $i$ & N & $\vec{L}$ & 30 \\
\hline 936 & 7 & 2 & 2 & .5 & 700 & N & 100 & L & 15 & 700 & 10 & 70 & N & L & 150 \\
\hline 938 & 3 & 2 & 1.5 & .3 & 500 & N & 300 & L & 151 & 1,000 & 5 & 70 & N & L & 150 \\
\hline 940 & 7 & 1.5 & 3 & .5 & 700 & N & 700 & L & 15 & 150 & 7 & 100 & $N$ & L & 30 \\
\hline 942 & 3 & 1.5 & 2 & .3 & 300 & N & 300 & N & 15 & 300 & 5 & 70 & N & $\underline{L}$ & 70 \\
\hline 944 & 3 & 2 & 2 & .5 & 700 & N & 300 & L & 201 & 1,000 & 5 & 150 & N & L & 100 \\
\hline 946 & 7 & 2 & 2 & .3 & 700 & $\mathrm{~N}$ & 200 & L & 201 & 1,000 & 7 & 70 & N & 10 & 100 \\
\hline 948 & 5 & .7 & 1.5 & .3 & 500 & N & 200 & L & 15 & 300 & 5 & 70 & N & 10 & 30 \\
\hline 953 & 3 & .7 & 1.5 & .3 & 500 & N & 150 & $\bar{L}$ & 15 & 30 & L & 20 & $\mathrm{~N}$ & L & 30 \\
\hline 967 & 7 & 3 & 3 & .5 & 1,000 & N & 300 & $L$ & 15 & 300 & 30 & 30 & N & L & 70 \\
\hline 969 & 10 & 3 & 3 & .5 & 1,000 & N & 100 & $\bar{L}$ & 151 & 1,000 & 10 & L & N & $\mathrm{L}$ & 150 \\
\hline 971 & 7 & 1.5 & 3 & .2 & 700 & N & 150 & L & 10 & 200 & 10 & L & N & L. & 30 \\
\hline 979 & 5 & 1 & 3 & .5 & 700 & N & 150 & $\bar{L}$ & 15 & 100 & 5 & 20 & N & $\mathrm{L}$ & 30 \\
\hline 983 & 3 & 1 & 3 & .3 & 500 & N & 300 & L & 15 & 100 & 7 & 70 & N & L & 30 \\
\hline 991 & 5 & 1 & 2 & .3 & 500 & $\mathrm{~N}$ & 200 & $\mathrm{~L}$ & 15 & 150 & L & 20 & $N$ & L & 30 \\
\hline 995 & 5 & 1.5 & 2 & .3 & 700 & N & 200 & L & 15 & 200 & L & 30 & $\mathbf{N}$ & L & 70 \\
\hline 1002 & & & & 1 & 700 & N & 150 & 1 & 20 & 700 & 10 & 300 & N & 15 & 100 \\
\hline 1006 & 7 & 3 & 2 & I & 1,000 & N & 100 & L & 201 & 1,500 & 7 & 70 & $\mathrm{~N}$ & L & 150 \\
\hline 1008 & 5 & 1.5 & 2 & .3 & 700 & $\mathrm{~N}$ & 200 & L & 15 & 300 & 10 & 30 & N & $\mathrm{L}$ & 50 \\
\hline 1028 & 10 & 1.5 & 3 & .3 & 700 & $\mathrm{~N}$ & 300 & $i$ & 15 & 200 & 10 & L & N & 10 & 30 \\
\hline 1031 & 5 & 1.5 & 3 & .3 & 700 & N & 300 & $i$ & 15 & 300 & L & $\hat{N}$ & N & 20 & 30 \\
\hline 1033 & 10 & 3 & 5 & .3 & 700 & N & 200 & l & 15 & 300 & L & 150 & $\mathrm{~N}$ & 10 & 70 \\
\hline 1040 & 3 & 1.5 & 2 & .2 & 500 & $\mathrm{~N}$ & 300 & $\bar{L}$ & 15 & 200 & 5 & 20 & N & 15 & 50 \\
\hline 1043 & 7 & 2 & 3 & .5 & 700 & $\mathrm{~N}$ & 200 & L. & 15 & 150 & 5 & 30 & N & 10 & 70 \\
\hline 1046 & 5 & 1.5 & 1.5 & .3 & 700 & N & 200 & L & 153 & 3,000 & 7 & 50 & $\mathrm{~N}$ & L & 70 \\
\hline 1048 & 3 & 1.5 & 1 & .2 & 300 & N & 300 & L & 15 & 500 & 7 & $\mathrm{~L}$ & N & L & 70 \\
\hline 1050 & 7 & 2 & 1.5 & .3 & 700 & $N$ & 150 & $\mathrm{~N}$ & 153 & 3,000 & 5 & 150 & N & L & 100 \\
\hline 1053 & 3 & 1.5 & 2 & .5 & 700 & N & 200 & $\mathrm{~L}$ & 15 & 300 & Ĺ & 100 & N & L & 50 \\
\hline 1055 & 5 & 1.5 & 2 & .7 & 1,000 & N & 150 & L & 15 & 200 & 7 & 150 & N & 10 & 70 \\
\hline 1058 & 7 & 3 & 3 & 1 & 1,000 & L & 100 & L & 202 & $2, \infty 00$ & 15 & 200 & N & L & 70 \\
\hline 1064 & 20 & .7 & 3 & .5 & 500 & N & 100 & L & 30 & 300 & 7 & 300 & N & 15 & 30 \\
\hline
\end{tabular}

y Contains $50 \mathrm{ppm}$ Sn. 
from the Glacier Primitive Area, Fremont Count $y$-Continued

\begin{tabular}{|c|c|c|c|c|c|c|c|c|c|}
\hline \multirow[b]{2}{*}{ Sample } & \multicolumn{6}{|c|}{$\begin{array}{c}\text { Semiquant i tative spectrographic } \\
\text { analyses--Continued } \\
\text { (ppm) }\end{array}$} & \multirow{2}{*}{$\begin{array}{c}\begin{array}{c}\text { Atomic } \\
\text { Absorption } \\
\text { (ppm) }\end{array} \\
\mathrm{Au}\end{array}$} & \multirow[b]{2}{*}{$\begin{array}{l}\text { Location } \\
\text { Sec-Twp-Rge }\end{array}$} & \multirow[b]{2}{*}{ Drainage basin } \\
\hline & $\begin{array}{c}\mathrm{Pb} \\
(10)\end{array}$ & $\begin{array}{l}5 c \\
(5) \\
\end{array}$ & $\begin{array}{c}5 r \\
(100) \\
\end{array}$ & $\begin{array}{c}v \\
(10) \\
\end{array}$ & $\begin{array}{c}Y \\
(10) \\
\end{array}$ & $\begin{array}{c}2 r \\
(10) \\
\end{array}$ & & & \\
\hline $\begin{array}{l}696 \\
710 \\
714 \\
718 \\
722\end{array}$ & $\begin{array}{r}\mathrm{L} \\
30 \\
20 \\
10 \\
100\end{array}$ & $\begin{array}{l}50 \\
20 \\
15 \\
15 \\
70\end{array}$ & $\begin{array}{r}L \\
L \\
100 \\
150 \\
300\end{array}$ & $\begin{array}{l}150 \\
150 \\
150 \\
100 \\
200\end{array}$ & $\begin{array}{r}100 \\
>200 \\
100 \\
70 \\
>200\end{array}$ & $\begin{array}{r}700 \\
>1,000 \\
500 \\
300 \\
>1,000\end{array}$ & $\begin{array}{r}0.02 \\
.04 \\
.02 \\
<.02 \\
.04\end{array}$ & $\begin{array}{r}13-38-106 \\
33-41-107 \\
4-40-107 \\
35-41-107 \\
19-41-107\end{array}$ & $\begin{array}{c}\text { Jakeys Fork. } \\
\text { Dry Creek. } \\
\text { Do. } \\
\text { Do. } \\
\text { Warm Spg Cr. }\end{array}$ \\
\hline $\begin{array}{l}725 \\
727 \\
729 \\
736 \\
742\end{array}$ & $\begin{array}{l}50 \\
15 \\
20 \\
10 \\
15\end{array}$ & $\begin{array}{l}20 \\
20 \\
70 \\
50 \\
70\end{array}$ & $\begin{array}{r}300 \\
300 \\
N \\
N \\
N\end{array}$ & $\begin{array}{r}300 \\
70 \\
70 \\
150 \\
150\end{array}$ & $\begin{array}{r}100 \\
50 \\
>200 \\
70 \\
150\end{array}$ & $\begin{array}{r}>1,000 \\
1,000 \\
>1,000 \\
1,000 \\
>1,000\end{array}$ & $\begin{array}{l}<.10 \\
<.04 \\
1.24 \\
<.10 \\
.40\end{array}$ & $\begin{array}{r}16-41-108 \\
21-41-108 \\
20-41-108 \\
10-37-106 \\
2-37-106\end{array}$ & $\begin{array}{c}\text { Wildcat Cr. } \\
\text { Warm Spg Cr. } \\
\text { Do. } \\
\text { Dry Cr. } \\
\text { Do. }\end{array}$ \\
\hline $\begin{array}{l}748 \\
761 \\
766 \\
771 \\
775\end{array}$ & $\begin{array}{l}10 \\
20 \\
50 \\
20 \\
10\end{array}$ & $\begin{array}{r}30 \\
70 \\
5 \\
30 \\
30\end{array}$ & $\begin{array}{r}100 \\
150 \\
200 \\
100 \\
L\end{array}$ & $\begin{array}{r}70 \\
150 \\
50 \\
100 \\
100\end{array}$ & $\begin{array}{r}50 \\
100 \\
30 \\
70 \\
50\end{array}$ & $\begin{array}{r}700 \\
>1,000 \\
700 \\
700 \\
1,000\end{array}$ & $\begin{array}{r}.04 \\
<.10 \\
<.04 \\
.04 \\
<.05\end{array}$ & $\begin{array}{l}1-37-106 \\
3-3-6 \\
23-41-107 \\
36-37-106 \\
30-37-105\end{array}$ & $\begin{array}{l}\text { Do. } \\
\text { Do. } \\
\text { Limekiln Gulch } \\
\text { Bull Lake Cr. } \\
\text { Do. }\end{array}$ \\
\hline $\begin{array}{l}778 \\
780 \\
784 \\
786 \\
789\end{array}$ & $\begin{array}{l}20 \\
20 \\
15 \\
10 \\
30\end{array}$ & $\begin{array}{l}20 \\
30 \\
15 \\
10 \\
30\end{array}$ & $\begin{array}{r}L \\
L \\
200 \\
L \\
500\end{array}$ & $\begin{array}{r}100 \\
100 \\
70 \\
50 \\
150\end{array}$ & $\begin{array}{r}100 \\
150 \\
70 \\
50 \\
70\end{array}$ & $\begin{array}{r}500 \\
1,000 \\
300 \\
70 \\
1,000\end{array}$ & $\begin{array}{l}<.10 \\
<.15 \\
<.11 \\
<.24 \\
<.027\end{array}$ & $\begin{array}{r}13-40-108 \\
36-41-108 \\
14-39-107 \\
11-38-106 \\
1-36-107\end{array}$ & $\begin{array}{c}\text { Jakeys Fork. } \\
\text { Do. } \\
\text { Torrey } \mathrm{Cr} \text {. } \\
\text { Dinwoody } \mathrm{Cr} \text {. } \\
\text { Bull Lake } \mathrm{Cr} \text {. }\end{array}$ \\
\hline $\begin{array}{l}791 \\
799 \\
910 \\
915 \\
917\end{array}$ & $\begin{array}{r}30 \\
20 \\
10 \\
L \\
15\end{array}$ & $\begin{array}{l}20 \\
15 \\
30 \\
20 \\
50\end{array}$ & $\begin{array}{r}100 \\
150 \\
L \\
L \\
L\end{array}$ & $\begin{array}{r}150 \\
70 \\
150 \\
100 \\
100\end{array}$ & $\begin{array}{r}100 \\
20 \\
70 \\
30 \\
150\end{array}$ & $\begin{array}{r}1,000 \\
70 \\
200 \\
500 \\
>1,000\end{array}$ & $\begin{array}{l}<.07 \\
<.18 \\
<.02 \\
<.02 \\
.02\end{array}$ & $\begin{array}{l}34-37-106 \\
34-3-6 \\
35-38-106 \\
30-38-105 \\
30-38-105\end{array}$ & $\begin{array}{c}\text { Do. } \\
\text { Bob Cr. } \\
\text { Dry Cr. } \\
\text { Do. } \\
\text { Do. }\end{array}$ \\
\hline $\begin{array}{l}920 \\
923 \\
926 \\
928 \\
932\end{array}$ & $\begin{array}{r}\mathrm{L} \\
10 \\
20 \\
20 \\
20\end{array}$ & $\begin{array}{l}30 \\
10 \\
30 \\
20 \\
20\end{array}$ & $\begin{array}{r}150 \\
L \\
500 \\
200 \\
L\end{array}$ & $\begin{array}{r}100 \\
70 \\
100 \\
70 \\
200\end{array}$ & $\begin{array}{r}50 \\
70 \\
100 \\
30 \\
150\end{array}$ & $\begin{array}{r}500 \\
1,000 \\
>1,000 \\
150 \\
>1,000\end{array}$ & $\begin{array}{l}<.02 \\
.04 \\
<.06 \\
<.027 \\
<.022\end{array}$ & $\begin{array}{l}31-38-105 \\
30-41-106 \\
35-37-106 \\
35-37-106 \\
27-37-106\end{array}$ & $\begin{array}{l}\text { Do. - } \\
\text { Jakeys Fork. } \\
\text { Bul1 Lake [r. } \\
\text { Do. } \\
\text { Do. }\end{array}$ \\
\hline $\begin{array}{l}936 \\
938 \\
940 \\
942 \\
944\end{array}$ & $\begin{array}{l}15 \\
15 \\
20 \\
15 \\
20\end{array}$ & $\begin{array}{l}20 \\
15 \\
15 \\
15 \\
15\end{array}$ & $\begin{array}{r}L \\
L \\
300 \\
100 \\
L\end{array}$ & $\begin{array}{r}100 \\
70 \\
70 \\
50 \\
70\end{array}$ & $\begin{array}{l}30 \\
30 \\
30 \\
20 \\
50\end{array}$ & $\begin{array}{r}1,000 \\
1,000 \\
150 \\
50 \\
700\end{array}$ & $\begin{array}{l}.02 \\
<.013 \\
.013 \\
<.021 \\
<.015\end{array}$ & $\begin{array}{l}25-37-106 \\
21-37-106 \\
21-37-106 \\
21-37-106 \\
22-37-106\end{array}$ & $\begin{array}{l}\text { Do. } \\
\text { Do. } \\
\text { Do. } \\
\text { Do. } \\
\text { Do. }\end{array}$ \\
\hline $\begin{array}{l}946 \\
948 \\
953 \\
967 \\
969\end{array}$ & $\begin{array}{l}15 \\
20 \\
10 \\
10 \\
10\end{array}$ & $\begin{array}{l}20 \\
15 \\
15 \\
30 \\
30\end{array}$ & $\begin{array}{r}150 \\
L \\
150 \\
100\end{array}$ & $\begin{array}{r}70 \\
70 \\
30 \\
100 \\
150\end{array}$ & $\begin{array}{r}50 \\
50 \\
100 \\
30 \\
30\end{array}$ & $\begin{array}{r}1,000 \\
200 \\
300 \\
300 \\
500\end{array}$ & $\begin{array}{l}<.074 \\
<.092 \\
<.031 \\
<.04 \\
<.10\end{array}$ & $\begin{array}{l}27-37-106 \\
26-37-106 \\
22-39-106 \\
10-36-106 \\
15-36-106\end{array}$ & $\begin{array}{l}\text { Do. } \\
\text { Do. } \\
\text { Dinwoody } C r . \\
\text { Bull Lake } C r \text {. } \\
\text { Do. }\end{array}$ \\
\hline $\begin{array}{l}971 \\
979 \\
983 \\
991 \\
995\end{array}$ & $\begin{array}{l}10 \\
15 \\
15 \\
15 \\
50\end{array}$ & $\begin{array}{l}15 \\
50 \\
30 \\
20 \\
15\end{array}$ & $\begin{array}{l}150 \\
150 \\
500 \\
200 \\
150\end{array}$ & $\begin{array}{r}100 \\
100 \\
70 \\
70 \\
70\end{array}$ & $\begin{array}{r}15 \\
150 \\
30 \\
70 \\
50\end{array}$ & $\begin{array}{r}20 \\
500 \\
150 \\
150 \\
300\end{array}$ & $\begin{array}{l}.10 \\
<.10 \\
<.10 \\
\cdots-.\end{array}$ & $\begin{array}{c}22-36-106 \\
23-36-106 \\
15-1-6 \\
4-35-106 \\
5-35-106\end{array}$ & $\begin{array}{l}\text { Do. } \\
\text { Do. } \\
\text { Do. } \\
\text { Do. } \\
\text { D. }\end{array}$ \\
\hline $\begin{array}{l}1002 \\
1006 \\
1008 \\
1028 \\
1031\end{array}$ & $\begin{array}{l}70 \\
15 \\
15 \\
50 \\
10\end{array}$ & $\begin{array}{l}30 \\
50 \\
20 \\
30 \\
20\end{array}$ & $\begin{array}{r}L \\
L \\
300 \\
300 \\
200\end{array}$ & $\begin{array}{r}100 \\
100 \\
50 \\
150 \\
70\end{array}$ & $\begin{array}{r}100 \\
50 \\
30 \\
100 \\
70\end{array}$ & $\begin{array}{r}1,000 \\
1,000 \\
300 \\
300 \\
500\end{array}$ & $\begin{array}{c}.10 \\
.1 \\
<.1 \\
.1 \\
.04\end{array}$ & $\begin{array}{r}28-37-105 \\
29-37-105 \\
29-37-105 \\
1-35-106 \\
35-36-106\end{array}$ & $\begin{array}{l}\text { Do. } \\
\text { Bull Lake } \mathrm{Cr} . \\
\text { Do. } \\
\text { Do. } \\
\text { Do. }\end{array}$ \\
\hline $\begin{array}{l}1033 \\
1040 \\
1043 \\
1046 \\
1048\end{array}$ & $\begin{array}{l}20 \\
15 \\
15 \\
15 \\
20\end{array}$ & $\begin{array}{l}30 \\
15 \\
20 \\
20 \\
15\end{array}$ & $\begin{array}{r}150 \\
300 \\
200 \\
L \\
150\end{array}$ & $\begin{array}{r}100 \\
50 \\
100 \\
70 \\
50\end{array}$ & $\begin{array}{l}70 \\
30 \\
50 \\
30 \\
20\end{array}$ & $\begin{array}{l}300 \\
100 \\
200 \\
150 \\
100\end{array}$ & $\begin{array}{r}.04 \\
.02 \\
<.1 \\
<.04 \\
<.04\end{array}$ & $\begin{array}{r}32-36-106 \\
33-36-106 \\
21-36-106 \\
6-37-105 \\
31-38-105\end{array}$ & $\begin{array}{c}\text { Do. } \\
\text { Do. } \\
\text { Do. } \\
\text { Dry Cr. } \\
\text { Do. }\end{array}$ \\
\hline $\begin{array}{l}1050 \\
1053 \\
1055 \\
1058 \\
1064\end{array}$ & $\begin{array}{l}15 \\
15 \\
15 \\
15 \\
20\end{array}$ & $\begin{array}{l}30 \\
15 \\
15 \\
50 \\
15\end{array}$ & $\begin{array}{r}L \\
100 \\
150 \\
200 \\
300\end{array}$ & $\begin{array}{r}70 \\
100 \\
70 \\
150 \\
300\end{array}$ & $\begin{array}{r}70 \\
30 \\
30 \\
150 \\
150\end{array}$ & $\begin{array}{r}300 \\
200 \\
500 \\
1,000 \\
1,000\end{array}$ & $\begin{array}{l}<.04 \\
<.04 \\
<.1 \\
<.04 \\
<.1\end{array}$ & $\begin{array}{r}30-38-105 \\
20-38-105 \\
4-37-105 \\
16-37-105 \\
9-35-106\end{array}$ & $\begin{array}{c}\text { Do. } \\
\text { Do. } \\
\text { Bob } c r . \\
\text { Do. } \\
\text { Bull Lake } c r .\end{array}$ \\
\hline
\end{tabular}


TABLE 11.-Analyses of pan-concentrated stream-sediment samples

Semiquantitative spectrographic analyses

\begin{tabular}{|c|c|c|c|c|c|c|c|c|c|c|c|c|c|c|c|}
\hline \multirow[b]{2}{*}{ Sample } & \multicolumn{4}{|c|}{ (percent) } & \multicolumn{11}{|c|}{$(\mathrm{pgm})$} \\
\hline & $\begin{array}{c}\mathrm{Fe} \\
(.05)\end{array}$ & $\begin{array}{c}\mathrm{Mg} \\
(.02)\end{array}$ & $\begin{array}{c}\mathrm{Ca} \\
(.05) \\
\end{array}$ & $\begin{array}{c}\mathrm{Ti} \\
(.002)\end{array}$ & $\begin{array}{c}\text { Mn } \\
(10)\end{array}$ & $\begin{array}{c}\mathrm{B} \\
(10) \\
\end{array}$ & $\begin{array}{l}8 \mathrm{Ba} \\
(20)\end{array}$ & $\begin{array}{l}\mathrm{Be} \\
\text { (1) }\end{array}$ & $\begin{array}{l}\text { Co } \\
(5) \\
\end{array}$ & $\begin{array}{l}C r \\
(5) \\
\end{array}$ & $\begin{array}{l}\mathrm{Cu} \\
\text { (5) }\end{array}$ & $\begin{array}{c}\mathrm{La} \\
(20) .\end{array}$ & $\begin{array}{l}140 \\
15)\end{array}$ & $\begin{array}{c}\text { Nb } \\
(10)\end{array}$ & $\begin{array}{l}\mathrm{Ni} \\
(5) \\
\end{array}$ \\
\hline $\begin{array}{l}1066 \\
1070 \\
1075 \\
1076 \\
1077\end{array}$ & $\begin{array}{r}15 \\
7 \\
5 \\
3 \\
3\end{array}$ & $\begin{array}{l}1.5 \\
2.5 \\
1 \\
1\end{array}$ & $\begin{array}{l}3 \\
5 \\
3 \\
3 \\
2\end{array}$ & $\begin{array}{l}0.5 \\
1 \\
.5 \\
.3 \\
.3\end{array}$ & $\begin{array}{l}700 \\
700 \\
500 \\
500 \\
500\end{array}$ & $\begin{array}{l}\mathbf{N} \\
\mathbf{N} \\
\mathbf{N} \\
\mathbf{N} \\
\mathbf{N}\end{array}$ & $\begin{array}{l}200 \\
500 \\
200 \\
200 \\
300\end{array}$ & $\begin{array}{l}\text { N } \\
\text { L } \\
\text { L } \\
\text { L } \\
\text { L }\end{array}$ & $\begin{array}{r}30 \\
10 \\
15 \\
7 \\
10\end{array}$ & $\begin{array}{r}300 \\
30 \\
300 \\
70 \\
100\end{array}$ & $\begin{array}{l}7 \\
\mathrm{~L} \\
\mathrm{~L} \\
\mathrm{~N} \\
5\end{array}$ & $\begin{array}{r}150 \\
70 \\
100 \\
30 \\
20\end{array}$ & $\begin{array}{l}\mathbf{N} \\
\mathrm{L} \\
\mathrm{N} \\
\mathrm{N} \\
\mathrm{N}\end{array}$ & $\begin{array}{r}\mathrm{L} \\
20 \\
\mathrm{~L} \\
\mathrm{~L} \\
\mathrm{~L}\end{array}$ & $\begin{array}{l}20 \\
10 \\
50 \\
20 \\
30\end{array}$ \\
\hline $\begin{array}{l}1086 \\
1089 \\
1093\end{array}$ & $\begin{array}{l}5 \\
3 \\
7\end{array}$ & $\begin{array}{l}1.5 \\
1 \\
1.5\end{array}$ & $\begin{array}{l}2 \\
3 \\
5\end{array}$ & $\begin{array}{l}.5 \\
.3 \\
.5\end{array}$ & $\begin{array}{l}700 \\
700 \\
700\end{array}$ & $\begin{array}{l}\mathbf{N} \\
\mathbf{N} \\
\mathbf{N}\end{array}$ & $\begin{array}{l}300 \\
200 \\
300\end{array}$ & $\begin{array}{l}L \\
L\end{array}$ & $\begin{array}{l}15 \\
20 \\
10\end{array}$ & $\begin{array}{l}200 \\
150 \\
200\end{array}$ & $\begin{array}{l}\mathrm{L} \\
\mathrm{L}\end{array}$ & $\begin{array}{r}50 \\
70 \\
100 \\
\end{array}$ & $\begin{array}{l}\mathrm{N} \\
\mathrm{N} \\
\mathrm{N}\end{array}$ & $\begin{array}{r}L \\
L \\
20\end{array}$ & $\begin{array}{l}30 \\
30 \\
30\end{array}$ \\
\hline
\end{tabular}


from the Glacier Primistie Area, Fremont County-Continued

\begin{tabular}{|c|c|c|c|c|c|c|c|c|c|}
\hline \multirow[b]{2}{*}{ Sample } & \multicolumn{6}{|c|}{$\begin{array}{c}\text { Semiquantitative spect rographic } \\
\text { analyses -Continued } \\
\text { (ppm) }\end{array}$} & \multirow{2}{*}{$\begin{array}{c}\begin{array}{c}\text { Atomic } \\
\text { Absorption } \\
\text { (ppm) }\end{array} \\
\mathrm{Au}\end{array}$} & \multirow[b]{2}{*}{$\begin{array}{c}\text { Location } \\
\text { Sec-Twp-Rge }\end{array}$} & \multirow[b]{2}{*}{ Drainage basin } \\
\hline & $\begin{array}{c}\mathrm{Pb} \\
(10) \\
\end{array}$ & $\begin{array}{l}\text { Se } \\
\text { (5) }\end{array}$ & $\begin{array}{c}\text { Sr } \\
(100)\end{array}$ & $\begin{array}{c}v \\
(10) \\
\end{array}$ & $\begin{array}{c}Y \\
(10) \\
\end{array}$ & $\begin{array}{c}\mathrm{Zr} \\
(10)\end{array}$ & & & \\
\hline $\begin{array}{l}1066 \\
1070 \\
1075 \\
1076 \\
1077\end{array}$ & $\begin{array}{l}20 \\
50 \\
15 \\
15 \\
15\end{array}$ & $\begin{array}{l}15 \\
20 \\
30 \\
30 \\
30\end{array}$ & $\begin{array}{r}500 \\
1,000 \\
300 \\
200 \\
200\end{array}$ & $\begin{array}{r}200 \\
100 \\
100 \\
70 \\
70\end{array}$ & $\begin{array}{r}100 \\
70 \\
70 \\
30 \\
30\end{array}$ & $\begin{array}{r}300 \\
1,000 \\
300 \\
500 \\
200\end{array}$ & $\begin{array}{l}<0.1 \\
.02 \\
<.04 \\
<.04 \\
<.04\end{array}$ & $\begin{array}{r}9-35-106 \\
3-35-106 \\
16-36-106 \\
16-36-106 \\
16-36-106\end{array}$ & $\begin{array}{l}\text { Bull Lake Cr. } \\
\text { Do. } \\
\text { Do. } \\
\text { Do. } \\
\text { Do. }\end{array}$ \\
\hline $\begin{array}{l}1086 \\
1089 \\
1093\end{array}$ & $\begin{array}{l}15 \\
20 \\
15\end{array}$ & $\begin{array}{l}20 \\
20 \\
20\end{array}$ & $\begin{array}{l}500 \\
300 \\
300\end{array}$ & $\begin{array}{l}70 \\
70 \\
70\end{array}$ & $\begin{array}{r}50 \\
50 \\
100\end{array}$ & $\begin{array}{r}100 \\
100 \\
1,000\end{array}$ & $\begin{array}{l}--- \\
---\end{array}$ & $\begin{array}{l}35-36-106 \\
35-36-106 \\
15-1-6\end{array}$ & $\begin{array}{l}\text { Do. } \\
\text { Do. } \\
\text { Do. }\end{array}$ \\
\hline
\end{tabular}





\section{INDEX}

[Italic page numbers indicate major references]

A

Accessibility
Acknowledgments
Aeromagnetic survey
Albite -
Alluvium
Alpine Lake
Alpine Lakes shear zone
Alteration, relation to faulting 48,48,
Amsden Formation
Analysis, techniques
Anomalies, aeromagnetic
$\quad$ base metals
$\quad$ gold -
silver -

Arrow Mountain

Arsenic -

Atlantic City district _-_-_-_._._._- 26, 39

B

Barium

52,53

Barrus, R. B., written communication -..-- 8

Base metals --

Beryllium -...---0.-- 50

Bibliography -...- 60

Bighorn Dolomite --_-_-_-_.

Biotite -........-. 12, 18, 22, 23

Blue Hole Creek fault -..-_-_-_-_-_-_-_. 38

Blue Holes -.-_-_-_-_- 38

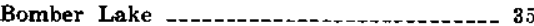

Breeden, L. B., analyst _.......... 41

Bridger Wilderness -....-... 3

Bull Lake --_.-_..- 7. 8

Bull Lake Creek -.------ 9, 14, 20, 43, 44, 46

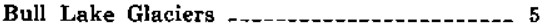

\section{C}

Chlorite

Chromium -

Citrate-soluble heavy metals _..._..._. 43

Cobalt

Concentrations of minerals in selected samples

47, 54

Conclusions

$--60$

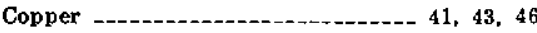

Crater Lake ............. 50

Crim. W. D., analyst

D

Darby Formation ......... 29

Day, Gordon, analyst _..._. 41

Decorative stone -............... 57

Desmond, J. V., analyst _......... 41
Page

Diabase ......... F24

Dikes -......... 24, 35, 43, 57

Dinwoody Creek _....... 4, 16, 32, 44, 48, 56

Dinwoody Lakes - -

Dow, V. T., and Young. W. E., written communication ….... 55

Downs Peak -_-_-_-_-_._- 35, 37

Dry Creek _..._._._-_._._ 4, 9, 14, 16, 43, 44

Dubois claims _.......... 54

$\mathbf{E}$

Epidote $19,22,23$

F

Faults _........... $35,37,38,48,52$

Felsenmeer -

Ficklin, W. H., analyst _._...........-. 41

Flathead Sandstone _........ 9, 22, 23, 28, 39

Forests ..-...-. 6

Fort Washakie _._._. 5

Fossils, brachiopod shells _._._........... 30

bryozoa -..-...- 30

coral -.-.-.-... 30

crinoid stems _..._._._. 30

Frisken, J. G., analyst -

\section{G}

Gallatin Limestone

Gannett Glacier -

Gannett Peak -..._..... 3. 35

Gardner, J. M., analyst _._._._.

Garnet ---_--_- 54

Gas -

Gas Hills distriet -.-

Geologic setting and history _......... 9, 30

Geyser Creek .... 30

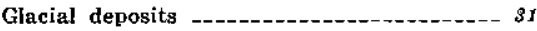

Gneissic rocks ................ 11, 24, 34

Goat Flat _..._-_._- $9,21,25,33,46,50$

Goat Flat diabase dike -......-.-- 35, 43, 57

Gold -

Goss, W. D., analyst _.

Gossan-bearing veins _................. $4 \mathrm{j}$

Granite, Middle Mountain -......-_ 21, 23

porphyritic - -

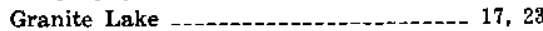

Grimes, D. J., analyst _._.

Gros Ventre Formation -_-_---_----- 28, 32

$\mathbf{H}$

Haffty, Joseph, analyst -

Hay Pass _. 
$\begin{array}{lr}\text { Hematite veins } & \text { Pag } \\ \text { Henry, Christopher, mapping and } & \text { F } 4 \text { r }\end{array}$

Hopkins, R. T., Jr., analyst Hornblende --.--_-_-_--_--_ 12, 18, 22, 23 Horse Ridge _............... 9, 33, 48

\section{I}

Indian Pass 5,59 Ink Wells Lakes _-_-_-_-_-_-_-_--- 45; pl. 1 Iron $39,47,55$

\section{$\mathbf{J}$}

Jackson Peak 5,37 Jade

Jakeys Fork $37,48,52$

Jakeys Fork fault $17,35,37,38$

\section{K}

Klondike Lake 46

Knife Point Mountain

\section{L}

Landslide debris

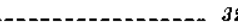
Lead --_._-_ 41, 43, 46, 47, 52, 54 Lime Kiln Gulch, mines and prospects -..- 52 Limestone -... 52 Little Milky Lake -..-_-_-_-_-_-_-_-_ 46

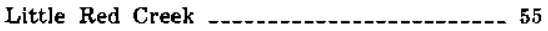
Little Warm Spring Creek _... 37, 48, 52, 54

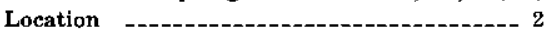
Louise Lake _-_._-_..- 21 M

Madison Limestone --_-_-_-_-_---- 29, 52 Magnesium _.............- 48 Magnetite -.-_-_-_-_-_-_-_- 19, 22, 23, 47 Metamorphism -_._. 11, 34 Microcline --_-_-_-_--_---- 12, 19, 22, 23 Middle Fork, Bull Lake Creek _-_-_- 20, 43 Middle Mountain batholith -..- 10, 12, 15, 21, $24,47,58$

Migmatite 15,22 ; pl. 1

Miller, R. L., analyst ........... 41

Mineral resources, economic potential -..- 44 $55,57,60$ history and production

Mines and prospects

Dinwoody Creek

Lime Kiln Gulch

Little Warm Spring Creek

Moon Lake

Red Creek

Union Pass

Whisky Mountain

Molybdenum

Moon Lake, mines and prospects

Mount Helen -

Mount Helen structural belt -..--- 10, 12, 15, 20, 34, 43; pl. 1

\section{$\mathbf{N}$}

Native Lake

14,43 Nickel - $43,48,54,56$

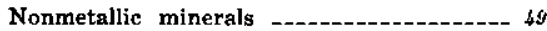
North Fork, Bull Lake Creek -..--- 14, 20, 46

Oil -

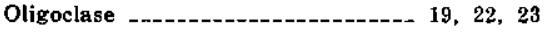

Packer, Duane, mapping and sampling ---- 6 Paleozoic rocks, thickness and composition _............... 27

Palladium -.--_- 45

Park City Formation -._._. 29, 49

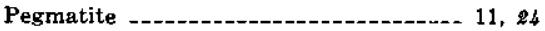

Phosphoria Formation --_-_-_-_--- 29, 49

Phosphorus -....... 55

Plagioclase -................. 12, 19, 20

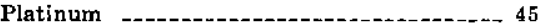

Popo Agie Primitive Area _..._._._ 8, 11, 22

Precambrian rocks -...-_... 10

Precious metals -

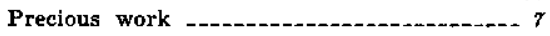

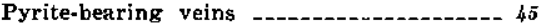

\section{Q}

Quartz -..-_-_-_-_-_ 12, 18, 22, 23, 43, 48

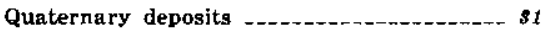

\section{$\mathbf{R}$}

Ram Flat

Rare earths -.............-. 50

Red Creek, mines and prospects --.------ 55

Red Granite Lake -

Relief -

Rhodium --.- 45

Rickard, M. S., analyst -

Riley, L. B., analyst _._.

Roemer, T. A., analyst _._-_-_-_ 41

Ross Lakes _-_.

Ross Lakes shear zone -....-.- 35, 38, 52, 69

Sampling --1-- 40

Sericite _........ 22

Shear zones _........... 10, 20, 35, 38, 52, 59

Shirley Basin -

Shoshone National Forest _....... 3

Silver --_-_-_-_- 45, 52, 56

Silver King claims -

Simpson Lake _........... 9, 11, 13, 23, 24, 35

Simpson Lake shear zone ............ 35, 59

Smithson, Harold, written communication - 54

Snowshoe Creek _................... 44

Soapstone Basin $\ldots \ldots$

Soapstone Lake

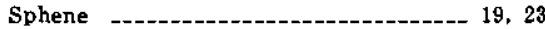

Stephenson, Z. C., analyst -_-_-_-_ 41

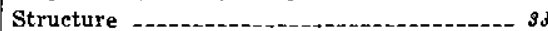

Sulfide minerals _................... 44, 45

Sulfur - 55

\section{T}

Talbot, D. D., sampling

Tensleep sandstone .... 29

Tertiary rocks -

Thickness and composition, Paleozoic rocks - -

Three Waters area 


\begin{tabular}{|c|c|}
\hline & w \\
\hline Гin & Warm Spring Creek \\
\hline oevs, A. J., analyst & Wells, A. W., analyst \\
\hline 3 & Whisky Basin Winter Range \\
\hline Orrey Creek & Whisky Creek canyon \\
\hline Correy Creek valley & Whisky Mountain, mines and prospects --- 53 \\
\hline orrey Lake & Wildcat Creek - \\
\hline riple Divide $\mathrm{P}$ & Wind River - \\
\hline 37 & $\begin{array}{l}\text { Wind River Basin } \\
\text { Wind River Formation } \\
\text { Wind River Indian Reservation.-1, } 37 \\
\text { Wind River Range, origin }\end{array}$ \\
\hline $\begin{array}{l}\text { Ultramafic rocks } \\
\text { Union Pass, mines and prospects } \\
\text { uranium claims }\end{array}$ & Wort, G. A., sampling - 6 \\
\hline Union Peak -.... 17, 24 & Yellowstone National Park \\
\hline $\begin{array}{l}\text { Upper Ross Lake-1- } \\
\text { Uranium }\end{array}$ & $\begin{array}{l}\text { Young, W. E., and Dow, V. T., written } \\
\text { communication }\end{array}$ \\
\hline$v$ & $z$ \\
\hline 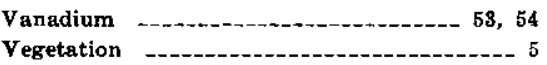 & 41,43 \\
\hline
\end{tabular}





\section{Studies Related to Wilderness- Primitive Areas, 1970}

GE OLOG I C A L S UR VEY B U L LE T I N 1319

This volume was published as separate chapters $A-F$

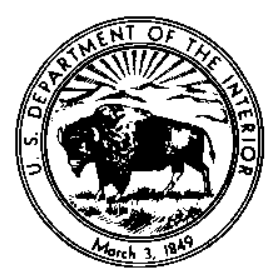


UNITED STATES DEPARTMENT OF THE INTERIOR

\section{GEOLOGICAL SURVEY}

William T. Pecora, Director 


\section{CONTENTS}

[Letters designate the separately published chapters]

(A) Mineral resources of the Agua Tibia Primitive Area, California, by William P. Irwin, Robert C. Greene, and Horace K. Thurber.

(B) Mineral resources of the Jack Creek basin, Madison County, Montana, by George E. Becraft, Thor H. Kiilsgaard, and Ronald M. Van Noy.

(C) Mineral resources of the Gore Range-Eagles Nest Primitive Area and vicinity, Summit and Eagle Counties, Colorado, by Ogden Tweto, Bruce Bryant, and Frank E. Williams.

(D) Mineral resources of the Sawtooth Primitive Area, Idaho, by Thor $\mathbf{H}$. Kiilsgaard, Val L. Freeman, and Joseph S. Coffman.

(E) Mineral resources of the Black Range Primitive Area, Grant, Sierra, and Catron Counties, New Mexico, by George E. Ericksen, Helmuth Wedow, Jr., Gordon P. Eaton, and George R. Leland.

(F) Mineral resources of the Glacier Primitive Area, Wyoming, by $\mathrm{H}$. C. Granger, E. J. McKay, R. E. Mattick, Lowell L. Patten, and Paul McIlroy. 





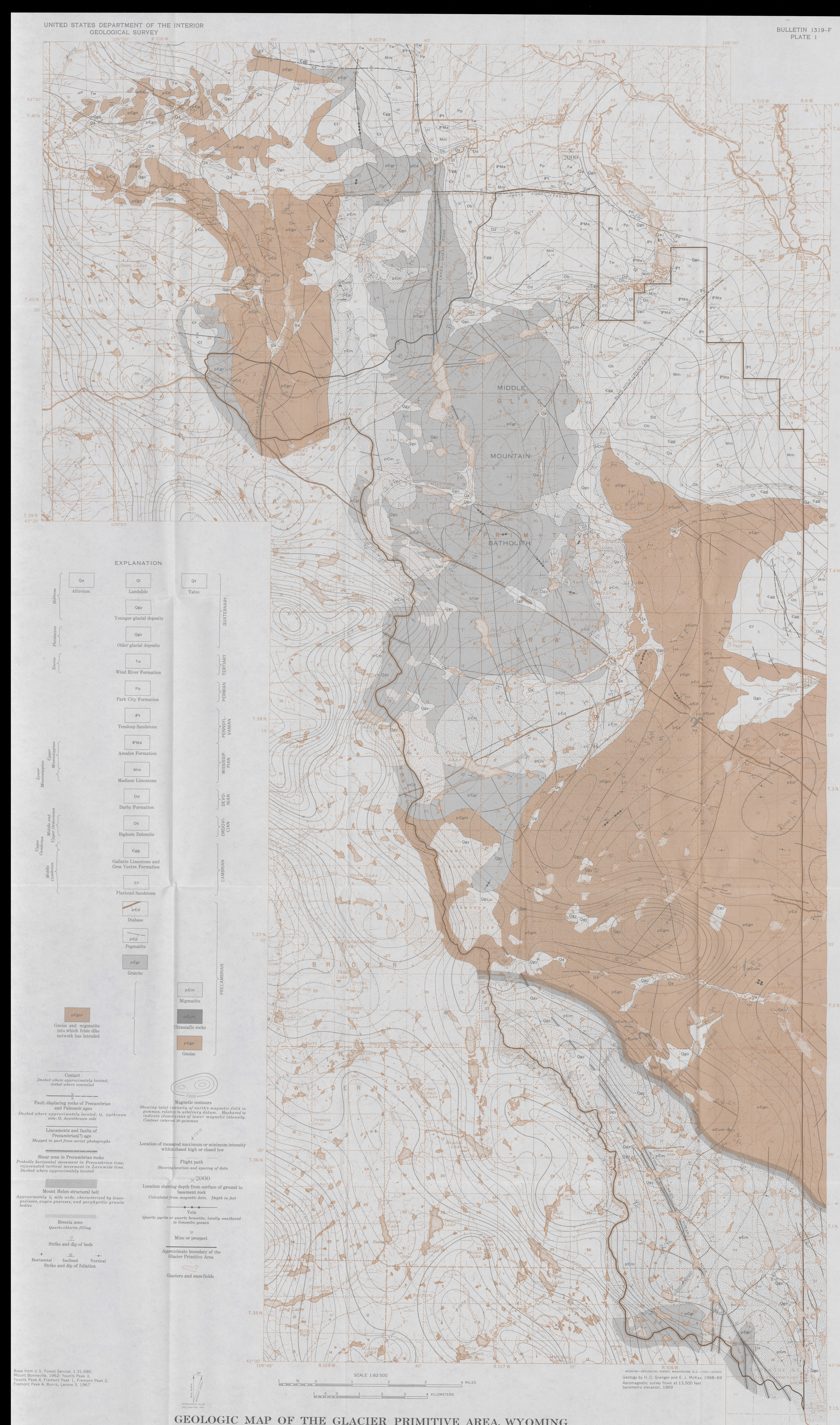

GEOLOGIC MAP OF THE GLACIER PRIMITIVE AREA, WYOMING 


